\author{
UNIVERSIDADE DE SÃO PAULO \\ FACULDADE DE ODONTOLOGIA DE BAURU
}

KARLLA CASSOL

Validação do Questionário CAP - "Conhecimento Atitudes e

Práticas" em gestantes expostas a agrotóxicos no Estado do

Paraná

BAURU 
KARLLA CASSOL

\section{Validação do Questionário CAP - "Conhecimento Atitudes e Práticas" em gestantes expostas a agrotóxicos no Estado do Paraná}

Tese apresentada à Faculdade de Odontologia de Bauru da Universidade de São Paulo para obtenção do título de Doutor em Ciências no Programa de Fonoaudiologia, na área de concentração Processos e Distúrbios da Comunicação.

Orientador: Profa. Dra. Andrea Cintra Lopes

\section{Versão Corrigida}

BAURU

2020 
Cassol, Karlla

Validação do Questionário CAP - "Conhecimento, Atitudes e Práticas” em gestantes expostas a agrotóxicos no estado do Paraná / Karlla Cassol. -- Bauru, 2020 .

215 p. : il. ; $31 \mathrm{~cm}$.

Tese (doutorado) -- Faculdade de Odontologia de Bauru, Universidade de São Paulo, 2020.

Orientador: Profa. Dra. Andrea Cintra Lopes

Nota: A versão original desta tese encontra-se disponível no Serviço de Biblioteca e Documentação da Faculdade de Odontologia de Bauru - FOB/USP.

Autorizo, exclusivamente para fins acadêmicos e científicos, a reprodução total ou parcial desta dissertação/tese, por processos fotocopiadores e outros meios eletrônicos.

Assinatura:

Data:

Comitê de Ética do Centro

Universitário Assis Gurgacz

Protocolo ${ }^{\circ}$ : 3.422 .972

Data: 28/06/2018 
ERRATA 
FOLHA DE APROVAÇÃO 


\section{DEDICATÓRIA}

Aos meus pais...

Agricultores, expostos a agrotóxicos, por toda uma vida dedicada ao trabalho do campo, no intuito de nos proporcionar um futuro "melhor" por meio da educação. Vocês são meu orgulho, meu amor incondicional e minha gratidão eterna. 


\section{AGRADECIMENTOS}

Á Deus, meu protetor maior, minha fortaleza, minha fé que se renova diariamente. Sou grata a cada instante, a cada conquista, a cada provação, porque é em Ti que confio a minha vida, a proteção da minha família e os meus melhores sentimentos.

A minha mãe Justina e meu pai Hermes pelo amor e cuidados imensuráveis, por cada sonho que eu sonhei, e vocês me permitiram realizar - mesmo com inúmeras dificuldades. Obrigada por confiarem e apoiarem cada escolha minha, sendo meus maiores motivadores, por me corrigirem sempre que necessário, e por estarem sempre presentes, em cada escolha, todos os dias, a todo momento - isso é um privilégio. Sem vocês eu nada seria.

Poder contar com vocês é “seguro”. São meus maiores exemplos, doutores da vida. Eu amo vocês!

Às minhas irmãs Juliane e Bruna, por se fazerem presentes em cada momento deste trajeto, e principalmente pelas constantes e incansáveis “correções” e “discussões”. Essa tese tem muito de vocês, logo, é de vocês também. Estarei sempre por vocês, assim como tenho a certeza que sempre estarão por mim!

Ao meu companheiro de vida Michel, por caminhar ao meu lado, respeitar e incentivar meus sonhos, e ser presente em todos os momentos. Meu coração é seu, e compartilhar essa vida contigo é incrível - eu amo você.

A minha orientadora, Andrea, por todo o seu carinho, que se difere de todo o mundo acadêmico, porque esse seu coração enorme, que transpassa a figura de professora, e se torna figura materna. Você me mostrou um lado muito mais humano da pesquisa, e certamente me espelho em ti como docente. E a Cris Magni, minha co-orientadora, que me acompanha desde a graduação. Obrigada por ser essa pessoa iluminada, e por me transmitir valores que ultrapassam a vida acadêmica!

À banca examinadora, e aos professores do Colegiado do Programa de Pós-Graduação em Fonoaudiologia da Faculdade de Odontologia de Bauru - Universidade de São Paulo, pelas valiosas sugestões, por acolherem meu trabalho, e pelo cuidado e carinho que tomaram ao criticá-lo, que contribuíram muito para minha pesquisa, assim como a minha formação. Me 
sinto privilegiada e orgulhosa por sempre ter estudado em escolas e universidades públicas, gratuitas e de alta qualidade.

As gestantes participantes da pesquisa, que gentilmente concederam seu tempo $e$ saberes, contribuindo com a pesquisa, e principalmente, com a minha vivência profissional. A todos os agricultores desse Brasil, aos meus mais próximos (vizinhos de comunidade), por seu trabalho intenso e constante em produzir alimentos para o país, embora muitas vezes desvalorizados: a todos vocês, meu respeito e orgulho, por tudo que representam - por me representarem também.

As Regionais de Saúde de Irati e Cascavel, as gestoras, enfermeiras, técnicas de enfermagem e agentes comunitárias de saúde, que conduzem tão humanamente seus trabalhos, e pelo acolhimento e reconhecimento da importância da pesquisa, dedicando-se tanto na realização da mesma.

A minha colega de graduação, Dra. Vanessa Veis Ribeiro, não só pela contribuição com as análises estatísticas, mas pelos esclarecimentos, sugestões e todo auxilio, quando me vi perdida em números.

Ao Centro Universitário Assis Gurgacz pela experiência docente, pela bolsa de incentivo acadêmico, e por contribuir tanto com a minha profissão. A todos os meus colegas de colegiado, em especial a Vandriele, por tanto carinho e por acrescentar tanto na minha vida.

À tantas outras pessoas encontradas nesse caminho, que contribuíram cada um a sua maneira, as amizades construídas e mantidas até hoje, em especial a Ms. Maria Fernanda, por toda ajuda e companheirismo nesse caminho, e a Ms Eloise Benacchio, pela amizade de uma vida. De maneira geral, a todos, que me incentivam, auxiliaram, facilitaram e se fizeram presente nesse momento, com amor e compreensão. Obrigada pelo aprendizado, pelo amadurecimento proporcionado, pelos momentos de descontração, que me motivaram a continuar.

\section{À todos, muito obrigada!}


EPIGRAFE

"Adquire sabedoria, adquire inteligência, e não te esqueças nem te apartes das palavras da minha boca."

Provérbios 4:5 


\section{RESUMO}

Gestantes expostas aos agrotóxicos podem sofrer diversos efeitos deletérios à sua saúde e de seu feto. Estudos realizados evidenciaram a preocupação quanto à exposição dessa população aos agrotóxicos utilizados na agricultura e experiências com o protocolo CAP (Conhecimento, Atitudes e Práticas) demonstraram ser esse um instrumento eficaz para compreender os fatores associados com a exposição aos agrotóxicos no período pré-natal. O objetivo deste estudo foi validar o questionário CAP em populações de gestantes expostas aos agrotóxicos no Estado do Paraná. Participaram do estudo 382 gestantes, divididas em dois grupos: Expostas a Agrotóxicos $(n=320)$ e Não Expostas $(n=62)$. O processo de validação envolveu a confiabilidade do instrumento, por meio dos testes de estabilidade, consistência interna e equivalência; e a validade de conteúdo, critério e constructo. As etapas da pesquisa foram desenvolvidas entre agosto de 2018 a dezembro de 2019 na região oeste e centro-oeste do Paraná, por meio das Regionais de Saúde. O instrumento demonstrou boa Confiabilidade quanto a Estabilidade e satisfatório quanto a Consistência Interna e Equivalência; a Validade de conteúdo por meio da avaliação de juízes demonstrou concordância aceitável; a Validade de critério por meio do critério estabelecido não apresentou associação; na análise da Validade de construto pela técnica de grupos conhecidos, demonstrou homogeneidade nas variáveis idade, nacionalidade e renda familiar. Este estudo permitiu concluir que a análise desenvolvida indicou que as propriedades psicométricas da adaptação transcultural da versão brasileira da escala são consistentes e adequadas para aplicação no Brasil, o que permite a recomendação da aplicação do instrumento em contexto nacional.

Palavras-chave: Agricultura; Agroquímicos; Gestantes; Estudo de Validação; Protocolos Clínicos. 


\section{ABSTRACT \\ Validation of the CAP Questionnaire - "Knowledge, Attitudes and Practices" in pregnant women exposed to pesticides in the State of Paraná}

Pregnant women exposed to pesticides can suffer several harmful effects to their health and that of their fetus. Studies carried out showed the concern regarding the exposure of this population to pesticides used in agriculture and experiences with the CAP protocol (Knowledge, Attitudes and Practices) demonstrated that this is an effective instrument to understand the factors associated with exposure to pesticides in the prenatal period. The aim of this study was to validate the CAP questionnaire in populations of pregnant women exposed to pesticides in the State of Paraná. 382 pregnant women participated in the study, divided into two groups: Exposed to Pesticides $(n=320)$ and Not Exposed $(n=62)$. The validation process involved the reliability of the instrument, through the tests of stability, internal consistency and equivalence; and the validity of content, criteria and construct. The stages of the research were developed between August 2018 and December 2019 in the western and central-western regions of Paraná, through the Regional Health Offices. The instrument demonstrated good reliability in terms of stability and satisfactory in terms of internal consistency and equivalence; the content validity through the evaluation of judges showed acceptable agreement; the criterion validity through the established criterion showed no association; in the analysis of the construct validity by the technique known groups, it demonstrated homogeneity in the variables age, nationality and family income. This study allowed us to conclude that the analysis developed indicated that the psychometric properties of the cross-cultural adaptation of the Brazilian version of the scale are consistent and suitable for application in Brazil, which allows the recommendation to apply the instrument in a national context.

Keywords: Poisoning; Agrochemicals; Pregnant Women; Validation Study; Clinical Protocols. 


\section{LISTA DE ILUSTRAÇÕES}

\section{FIGURAS}

Figura 1 - Evolução da produção de grãos e área plantada no Brasil 1976/77- 2016/17

Figura 2 - Distribuição das grandes Regiões Brasileiras na produção agrícola

Figura 3 - $\quad$ Mapa do Estado do Paraná

Figura 4 - Distribuição da produção agrícola paranaense em $2019 \quad 37$

Figura 5 - Comparação da área plantada x consumo de agrotóxicos em $\quad 38$ 2015 no Paraná

Figura 6 - Percentual de Frequência de casos notificados de intoxicação por agrotóxico segundo faixa etária - 2012 a 2016

Figura 7 - Percentual de Frequência de casos notificados de intoxicação por agrotóxico segundo a via de exposição - 2012 a 2016

Figura 8 - Transferência de agrotóxicos da mãe para o feto $\quad 68$

Figura 9 - Ilustração resumida do processo de tradução do questionário CAP (CASSOL; MAGNI, 2015)

Figura 10 - Ilustração da 10a . Regional de Saúde - Cascavel 100

Figura 11 - Ilustração da 4 $4^{\mathrm{a}}$. Regional de Saúde - Irati 100

Figura 12 - Ilustração do Processo de Validação do Questionário CAP 103

Figura 13 - Benefício médico utilizado para realizar o pré-natal 112

Figura 14 - Tópicos discutidos no treinamento sobre agrotóxicos 114

Figura 15 - Distribuição de Estabelecimentos com produtor do sexo 136 feminino, por Unidade da Federação

\section{LISTA DE QUADROS}

Quadro 1 - Classificação das Intoxicações por Agrotóxicos 49

Quadro 2 - Fatores determinantes de intoxicações 52 


\section{LISTA DE TABELAS}

Tabela 1 - Intoxicação exógena - Notificações registradas no Sinan Net - Brasil 38

Tabela 2 - $\quad$ Classificação Toxicológica de acordo com a Dose Letal (DL). 42

Tabela 3 - Intoxicação exógena - Notificações registradas no Sinan Net - Brasil 46

Tabela 4 - $\quad$ Notificações registradas no SINAN net por Região do Brasil 47

Tabela 5 - Análise descritiva das variáveis qualitativas nominais de $\quad 111$ caracterização do local onde vive, ocupação das atividades e uso de agrotóxicos em gestantes do Grupo Expostas

Tabela 6 - Análise descritiva das variáveis quantitativas contínuas do construto de "Conhecimento" do Questionário CAP em gestantes do Grupo Expostas

Tabela 7 - Análise descritiva das variáveis quantitativas contínuas do construto de "Atitudes" do Questionário CAP em gestantes do Grupo Expostas

Tabela 8 - Análise descritiva das variáveis quantitativas contínuas do construto de práticas do Questionário CAP em gestantes do Grupo Expostas

Tabela 9 - Confiabilidade teste-reteste para as variáveis quantitativas contínuas dos construtos de conhecimento, atitudes e práticas do Questionário CAP em gestantes do Grupo Expostas

Tabela 10 - Confiabilidade teste-reteste para as variáveis qualitativas nominais do construto de conhecimento do Questionário CAP em gestantes do Grupo Expostas

Tabela 11 - Análise do coeficiente de concordância do Questionário CAP

Tabela 12 - Análise do Índice de Validade de Conteúdo do Questionário CAP

Tabela 13 - Comparação dos escores das perguntas do construto "Conhecimento" do Questionário CAP em função dos grupos independentes constituídos a partir das respostas a uma pergunta que avalia o mesmo construto em agricultoras do Grupo Expostas

Tabela 14 - Comparação dos escores das perguntas do construto "Atitudes" do Questionário CAP em função dos grupos independentes constituídos a partir das respostas a uma pergunta que avalia o mesmo construto em agricultoras do Grupo Expostas

Tabela 15 - Análise dos escores das perguntas do construto "Práticas" do 
Questionário CAP em função dos grupos independentes constituídos a partir das respostas a uma pergunta que avalia o mesmo construto em agricultoras do Grupo Expostas

Tabela 16 - Análise descritiva das variáveis quantitativas de caracterização em gestantes do Grupo Expostas e do Grupo Não Expostas

Tabela 17 - Análise descritiva das variáveis qualitativas nominais de caracterização em gestantes do Grupo Expostas e do Grupo Não Expostas

Tabela 18 - Análise dos escores das perguntas dos construtos "Conhecimento, atitudes e práticas" em função dos grupos em agricultoras 


\section{LISTA DE ABREVIATURAS E SIGLAS}

ABRASCO

ABS

ACS

ANDEF

ANVISA

BNDES

CAP

CCI

CENEPI

CEPSH/SESA/PR

CEVA

CIATS

CNS

CONAB

DATASUS

DDT

DL

DVVZI

ELA

EPI

FIOCRUZ

GT

IBAMA

IBGE

IDH

IPARDES

IVC

KAP

LNC

LNH

MS
Associação Brasileira de Saúde Coletiva

Atenção Básica em Saúde

Agente Comunitária de Saúde

Associação Nacional de Defesa Vegetal

Agência Nacional de Vigilância Sanitária

Banco Nacional de Desenvolvimento Econômico e Social

Conhecimento, Atitudes e Práticas

COeficiente de correlação Interclasse

Centro Nacional de Epidemiologia

Comitê de Ética em Pesquisa Envolvendo Seres Humanos da Secretaria da Saúde do Paraná

Centro de Vigilância Ambiental

Centro de Informação e Assistência Toxicológica

Conselho Nacional em Saúde

Companhia Nacional de Abastecimento

Departamento de Informática do Sistema Único de Saúde

Dicloro-Difenil-Tricloroetano

Dose Letal

Divisão de Vigilância de Zoonoses e Intoxicações

Esclerose Laretal Amiotrófica

Equipamento de Proteção Individual

Fundação Oswaldo Cruz

Grupo de Trabalho

Instituto Brasileiro do Meio Ambiente e Dos Recursos Renováveis

Instituto Brasileiro de Geografia e Estatística

Índice de Desenvolvimento Humano

Instituto Paranaense de Desenvolvimento Econômico e Social

Indice de Validade de Conteúdo

Knowledges, atitudes and practices.

Lista de Notificação Compulsória

Linfoma Não Hodgkin

Ministério da Saúde 
MT

MTE

NBCAL

NR

NV

OMS

OPAS

PARA

PEVASPEA-PR

PHPN

PIB

PNAISC

PNSIPCF

PNST

RENACIAT

SES

SESA-PR

SINAN

SINITOX

SUS

SVS

TCLE

UBS

VIGIAGUA

VIGIQUIM

VSPEA
Ministério do Trabalho

Ministério do Trabalho e Econômia

Norma Brasileira de Comercialização de Alimentos para Lactentes e $\mathrm{Cr}$ Infância, Bicos, Chupetas e Mamadeiras

Norma Regulamentadora

Nascidos Vivos

Organização Mundial da Saúde

Organização Pan-Americana de Saúde

Programa de Análise de Resíduos de Agrotóxicos em Alimentos

Plano Estadual de Vigilância e Atenção à Saúde de Populações Exposta Agrotóxicos

Programa de Humanização no Pré-natal e Nascimento

Produto Interno Bruto

Política Nacional de Atenção Integral à Saúde da Criança

Política Nacional de Saúde Integral das Populações do Campo e da Flo1 Política Nacional de Saúde do Trabalhador

Rede Nacional de Centros de Informação e Assistência Toxicológica Secretaria Estadual de Saúde

Secretaria Estadual de Saúde do Paraná

Sistema de Informação de Agravos de Notificação

Sistema Nacional de Informações Tóxico-Farmacológicas

Sistema Único de Saúde

Secretaria de Vigilância da Saúde

Termo de Consentimento Livre e Esclarecido

Unidade Básica de Saúde

Programa Nacional de Vigilância da Qualidade da Água para Consumo Vigilância em Saúde Ambiental Relacionada às Substâncias Químicas Vigilância em Saúde de Populações Expostas a Agrotóxicos 


\section{SUMÁRIO}

$1 \quad$ INTRODUÇÃO

2 REVISÃO DE LITERATURA 27

2.1 A AGRICULTURA E O USO DE AGROTÓXICOS 27

2.1.1 A agricultura Brasileira e a origem dos agrotóxicos - contexto 27 histórico e perspectivas atuais

2.1.2 A agricultura no Estado do Paraná e os casos de intoxicação agrícola 35

2.1.3 Agrotóxicos: definição, classificação e o impacto no manuseio 41

2.1.4 Exposição a agrotóxicos: impactos na saúde $\mathbf{5 6}$

2.2 A GESTAÇÃO E OS IMPACTOS DECORRENTES DOS 65 AGROTÓXICOS

2.2.1 O período gestacional $\quad 65$

$\begin{array}{lll}2.2 .2 & \text { Efeitos teratogênicos dos agrotóxicos } & \mathbf{6 7}\end{array}$

2.2.3 Políticas Públicas e o cuidado à gestante exposta a agrotóxicos 72

2.3 VALIDAÇÃO DE INSTRUMENTOS 75

2.3.1 Processo de Tradução e adaptação de protocolos

2.3.2 Validação de instrumentos $\quad \mathbf{7 8}$

2.3.2.1 Confiabilidade $\quad 79$

$\begin{array}{lll}2.3 .2 .2 & \text { Validade } & 81\end{array}$

2.3.3 Aplicabilidade dos protocolos CAP - Conhecimento, Atitudes e 83 Práticas

2.3.4 Apresentação do Questionário CAP em português - Processo de $\quad 87$ Tradução e retrotradução do instrumento

2.3.5 Descrição do instrumento CAP - Conhecimento, Atitudes e Práticas 89

3 OBJETIVOS 95

3.1 OBJETIVOS ESPECÍFICOS 95

4 METODOLOGIA 99

4.1 ASPECTOS ÉTICOS 99

$\begin{array}{lll}4.2 & \text { POPULAÇÃO E AMOSTRA } & 99\end{array}$

4.3 CASUÍSTICA 101

4.4 APRESENTAÇÃO DO INSTRUMENTO 101

4.5 VALIDAÇÃO DO INSTRUMENTO 102 
4.5.1 Confiabilidade do questionário CAP $\mathbf{1 0 3}$

$\begin{array}{lll}\text { 4.5.2 Validade do questionário CAP } & \mathbf{1 0 4}\end{array}$

$\begin{array}{lll}4.6 & \text { APLICAÇÃO DO INSTRUMENTO } & 105\end{array}$

4.7 ANÁLISE DE DADOS 105

5 RESULTADOS 109

5.1 CARACTERIZAÇÃO DA AMOSTRA 109

5.2 ANÁLISE DO CONHECIMENTO, DAS ATITUDES E DAS 115

PRÁTICAS

5.3 RESULTADOS PARA CONFIABILIDADE 115

5.3.1 Confiabilidade quanto a Estabilidade $\mathbf{1 1 5}$

$\begin{array}{ll}\text { 5.3.2 Confiabilidade quanto a Consistência Interna } & \mathbf{1 1 7}\end{array}$

$\begin{array}{lll}\text { 5.3.3 Confiabilidade quanto a Equivalência } & \mathbf{1 1 7}\end{array}$

$\begin{array}{lll}5.4 & \text { RESULTADOS PARA VALIDADE } & 118\end{array}$

5.4.1 Validade de Conteúdo 118

$\begin{array}{lll}5.4 .2 & \mathbf{1 1 8}\end{array}$

$\begin{array}{lll}5.4 .3 & \mathbf{1 2 3}\end{array}$

6 DISCUSSÃO 131

6.1 ANÁLISE DESCRITIVA 131

6.2 ANÁLISE DO CONHECIMENTO, DAS ATITUDES E DAS 142

PRÁTICAS

6.3 ANÁLISE DAS ETAPAS DE VALIDAÇÃO DO QUESTIONÁRIO 150

6.3.1 Análise da Confiabilidade 151

6.3.2 Análise da Validade 156

$\begin{array}{lll}7 & \text { CONCLUSÃO } & 167\end{array}$

REFERÊNCIAS

$\begin{array}{ll}\text { ANEXOS } & 199\end{array}$

ANEXO A - PARECER DE APROVAÇÃO DO COMITÊ DE ÉTICA 201

ANEXO B - QUESTIONÁRIO KAP EM PORTUGUÊS 204

APÊNDICES

APÊNDICE A - TERMO DE CONSENTIMENTO LIVRE E 213

ESCLARECIDO (TCLE)

APÊNDICE B - TABELA DE ANÁLISE CONSISTENCIA INTERNA 214 
1- Introdução 



\section{INTRODUÇAO}

A produção agrícola brasileira tem se tornado cada vez mais eficiente ao longo dos anos. Com esse motivo, o setor econômico tem investido na fabricação e na comercialização de fertilizantes e agrotóxicos para o controle de pragas e ervas daninhas. Tal realidade faz com que se intensifiquem as discussões sobre os impactos da utilização indiscriminada de agrotóxicos e suas consequências na saúde pública (CARNEIRO, 2012, 2015; BELCHIOR et al., 2014; BRASIL, 2013, 2017a;). Isso porque, é certo que os perigos não se restringem ao trabalhador rural, abrangem o ambiente, o alimento produzido e podem, inclusive, se acumular no organismo humano, trazendo diversos efeitos agudos e crônicos, imediatos ou posteriores.

Dados da Agência Nacional de Vigilância Sanitária (ANVISA) colocam o Brasil como maior consumidor de agrotóxico mundial nas últimas safras, com perspectiva de aumentar a cada ano o uso intensivo de agrotóxicos nas lavouras (CARNEIRO, 2012, 2015; PIGNATI, 2017). Nesse ranking, o Paraná é o terceiro maior consumidor do Brasil, o que o torna um referencial válido para pesquisas relacionadas ao tema (IPARDES, 2020).

Por lei, os agrotóxicos são definidos como produtos e agentes resultantes de processos físicos, químicos ou biológicos, destinados ao uso nos setores de produção agrícola com a finalidade de alterar a composição da flora ou da fauna, a fim de preservá-las da ação danosa de seres vivos considerados nocivos (BRASIL, 1989, Lei No 7.802, p.1). São categorizados de diversas formas, sendo as principais: de acordo com o modo de ação no organismo alvo, em relação à sua estrutura química, quanto aos efeitos que causam à saúde humana e pela avaliação da neurotoxicidade. Dentre essas, a classificação de acordo com o grau de toxicidade para o ser humano é fundamental, pois informa a toxidade desses produtos relacionados com a Dose Letal 50 (DL50\%) $)^{1}$.Assim, com base nas DL50 de várias substâncias, são estabelecidas classes toxicológicas de produtos químicos e farmacológicos (BRASIL, 2005).

Os seres humanos, quando expostos aos agrotóxicos, podem apresentar sinais e sintomas de intoxicação agudos e crônicos, classificados em leves, moderados e graves. A intoxicação aguda é caracterizada por sintomas referentes à cefaleia, irritação, dermatite de contato irritativa ou por hipersensibilidade, náusea, vômitos, cólicas abdominais, tonturas, fraqueza generalizada, salivação e sudorese aumentadas, hipotensão, arritmia cardíaca,

${ }^{1}$ A DL 50 ou dose letal média de uma substância expressa o grau de toxicidade aguda de substâncias químicas. Correspondem às doses que provavelmente matam 50\% dos animais de um lote utilizados para experiência. São valores calculados estatisticamente a partir de dados obtidos experimentalmente (ANVISA, 2012). 
insuficiência respiratória, edema agudo de pulmão, convulsões, alterações da consciência, choque, coma, podendo evoluir para óbito.

Quanto aos sintomas crônicos e subcrônicos, diversos estudos ainda em comprovação científica afirmam que as manifestações sintomáticas ocorrem por meio de patologias que atingem órgãos e sistemas, com destaque para os problemas imunológicos, hematológicos, hepáticos, neurológicos, malformações congênitas e tumores (BRASIL, 2006).

Embora a discussão sobre os efeitos deletérios dos agrotóxicos no organismo das populações expostas direta ou indiretamente não seja recente, muito pouco se tem feito em relação à atenção e intervenção concreta sobre essa prática. As ações que visam minimizar os impactos das intoxicações ainda são segregadas e pouco efetivas, dificultando o controle sobre o consumo e mau uso desses produtos químicos.

Os estudos científicos mais atuais se atêm a investigar os possíveis danos à saúde dos agricultores, com atenção principal às mulheres gestantes, caracterizadas como população de maior risco. As pesquisas nessa área apontam para complicações e intercorrências na gravidez, muitas vezes desconhecidas pela própria mulher. Essa questão transparece uma preocupação emergente de cuidado à saúde, mas principalmente evidencia o grande risco que uma população frágil, como a das gestantes, está exposta (GONÇALVES et al., 2011; COSTA; TAKESSHITA; JACOBUCCI FARAH, 2013; OLIVEIRA et al., 2014; DUTRA; FERREIRA, 2017).

Fato é que a existência de quaisquer intercorrências na gestação pode gerar desfechos indesejáveis com diferentes comprometimentos ao feto, como baixo peso ao nascimento, prematuridade e malformações congênitas, que são considerados fatores de risco para a mortalidade infantil (COSTA; TAKESSHITA; JACOBUCCI FARAH, 2013; CARNEIRO, 2012, 2015; DUTRA; FERREIRA, 2017). Dentre esses fatores, que colocam em risco a saúde da gestante, incluem-se a exposição demasiada aos agrotóxicos, cujos malefícios já foram evidenciados por pesquisas experimentais, e seguem em andamento em seres humanos, permitindo antecipar a presença de alterações nos recém-nascidos, filhos de mães que estiveram expostas aos agrotóxicos antes e durante a gestação (CLEMENTI et al., 2007; GONÇALVES et al., 2011; PALMA, 2011; COSTA; TAKESSHITA; JACOBUCCI FARAH, 2013).

Embora já existam comprovações sobre as consequências patológicas causadas pelos agrotóxicos, no sistema de saúde pública no Brasil são escassos protocolos que atendam, com eficiência e eficácia, as mulheres trabalhadoras expostas aos agrotóxicos durante o período prénatal. Pode-se inferir que essa ausência se baseia na falsa ideia de que a mulher, por permanecer em casa, longe do trabalho agrícola, não estaria exposta aos efeitos danosos. Indubitavelmente, 
a gestante que reside em áreas agrícolas ou próxima a elas apresenta maior risco quando comparada a outras gestantes, o que requer maior atenção e acompanhamento das políticas de saúde pública. Não somente são necessárias ações eficazes de cuidado, como também é urgente o estabelecimento de um protocolo que possa enquadrar esta gestante na categoria de alto risco, e não apenas no risco habitual, permitindo a ela o acesso a exames mais específicos que possam, inclusive, avaliar os níveis de toxicidade presentes no organismo.

A esse respeito, já existem em outros países, a preocupação quanto à exposição das gestantes aos agrotóxicos utilizados na agricultura, sendo que na Tailândia já estão sendo realizadas experiências com o protocolo CAP (Conhecimento, Atitudes e Práticas) ${ }^{2}$ por ser esse um instrumento eficaz para compreender os fatores associados com a exposição aos agrotóxicos no período pré-natal (LORENZ et al., 2012).

É oportuno esclarecer que os protocolos CAP e suas respectivas traduções ("CAP” na língua portuguesa) são usados a nível mundial para avaliar o conhecimento, as atitudes e as práticas de diversos assuntos e em diferentes populações.

A saber, o inquérito CAP é uma avaliação formativa, que objetiva coletar dados de uma parcela populacional e favorecer a elaboração de intervenções. A técnica consiste em questionar o indivíduo para recordar fatos específicos; identificar as habilidades para a resolução de problemas, diferenciar as opiniões, sentimentos, predisposições e crenças referentes a um objetivo, pessoa ou situação; e conhecer as ações praticadas e decisões tomadas diante de determinadas condições.

Cumpre destacar o quanto é fundamental compreender os níveis de conhecimento, atitude e prática de uma determinada população, visto que esses dados permitem o reconhecimento das reais necessidades ou problemas, possibilitando a adequação das possíveis intervenções, direcionando-as para a problemática em questão.

Pela observação dos estudos científicos e condutas de saúde pública destinadas às gestantes, especificamente aquelas que residem na área rural, verifica-se a inexistência de instrumentos capazes de verificar o conhecimento dessas gestantes sobre os agrotóxicos, as atitudes preventivas e as práticas que adotam para se proteger.

Nesse sentido, Cassol e Magni (2015) realizaram a tradução do protocolo KAP (Knowledges, Attitudes and Practices), desenvolvido por Lorenz e colaboradores (2012), o qual se constitui como um instrumento que colabora para a identificação dos conhecimentos, atitudes e práticas das mulheres gestantes no que se refere à exposição aos agrotóxicos. Nesse estudo

\footnotetext{
${ }^{2}$ Em inglês KAP - "Knowledge, attitudes and practices".
} 
preliminar realizado no Brasil, foi possível verificar associações significativas entre o conhecimento das mulheres e a fase da gestação, além de indicar comportamentos caracterizados como de riscos, bem como as práticas seguras diante dos produtos tóxicos. A partir dos resultados encontrados, também foi possível depreender que quanto mais tempo de gestação, maior é o conhecimento sobre os riscos da exposição aos agrotóxicos, como também a tomada de atitudes e práticas seguras durante o período gestacional, tanto em casa como no trabalho (CASSOL; MAGNI, 2015).

Diante da notoriedade que o Questionário CAP alcança no trabalho preventivo de saúde pública voltada às gestantes, faz-se necessária realizar mais estudos que viabilizem a validação do conteúdo deste protocolo, com um número maior de participantes, motivo pelo qual este projeto de pesquisa se propõe. A partir disso, a pergunta problema que norteia esta pesquisa é: o questionário CAP “Conhecimento Atitudes e Práticas”, testado no Estado do Paraná, é valido para avaliar gestantes brasileiras expostas aos agrotóxicos?

Ocorre que, apesar dos resultados favoráveis à utilização deste protocolo CAP para levantamento do conhecimento, das atitudes e das práticas de gestantes agricultoras no Brasil, para obter melhor confiabilidade é necessária sua validação transcultural utilizando uma amostra maior de participantes.

Assim, ao alcançar um esboço maior de pesquisados, efetiva-se a validação do protocolo CAP como um instrumento a ser usado por profissionais da saúde na identificação dos fatores de risco que norteiam a temática agrotóxicos em gestantes.

Embora sejam escassas as pesquisas científicas sobre práticas inseguras relacionadas ao uso do agrotóxico, há fortes indícios de que ocorrem alterações na saúde das gestantes, e que essas podem ser atribuídas ao comportamento de risco diante da exposição involuntária a esses agentes.

No entanto, seriam necessárias medidas reais de exposição para confirmar essa hipótese. Esse não será o foco deste estudo, mas as respostas obtidas a partir da aplicação deste instrumento podem ser úteis para futuras intervenções. 
2 - Revisão de Literatura 



\section{REVISÃO DE LITERATURA}

\subsection{A AGRICULTURA E O USO DE AGROTÓXICOS}

Neste capítulo será apresentado uma síntese histórica a respeito do surgimento e desenvolvimento da agricultura no contexto nacional e estadual, discutindo as implicações da chamada "Revolução Verde" e a entrada definitiva dos produtos agrotóxicos no campo. Nesse ponto, discute-se acerca dos benefícios com aumento da produção agrícola e melhoria econômica, e os contrapontos da sua exposição, como contrabando e armazenamento de recipientes indevidos, que geram contaminação ao meio ambiente e as espécies humanas e animais expostas.

Pretende-se contextualizar a população pesquisada e contribuir para a compreensão de como o processo de mecanização da agricultura paranaense influenciou no ambiente e consequentemente, na saúde humana. As situações destacadas servem para esclarecer que a busca pela alta produtividade agrícola tem interferência no meio ambiente, alertando para a necessidade de preocupação quanto aos efeitos acumulativos dos agrotóxicos no homem e na natureza.

\subsubsection{A agricultura Brasileira e a origem dos agrotóxicos - contexto histórico e perspectivas atuais}

O intenso crescimento da população mundial originou aumento da demanda de alimentos a fim de prover sustento a população. Influenciado por mudanças nos hábitos alimentares, principalmente pelo maior consumo de proteínas, o agronegócio, tanto a nível mundial quanto nacional, viveu um expressivo crescimento na exportação de produtos oriundos da agricultura. Esse movimento promoveu salto no crescimento econômico, melhorando diretamente a renda de famílias ligadas a agricultura, mas em contradição originou forte migração da população do campo para os centros urbanos (BRITO, 2006). Entretanto, produzir mais alimentos, matérias-primas e biocombustíveis com baixo custo para atender à crescente demanda da população mundial, de forma sustentável e sem agredir o planeta, é um desafio que o Brasil e os demais países exportadores tendem a enfrentar.

A agricultura é considerada atualmente a base da produção de alimentos em todo o mundo. Seu contexto histórico retrata desde a pré-história, com relatos de atividades de cultivo de plantas com a finalidade de satisfazer necessidades humanas de sobrevivência. O século XIX foi um período marcado por grandes descobertas na agricultura mundial, entretanto, somente a 
partir da segunda metade do século XX, nos anos 60 a 70, os países desenvolvidos, pretendendo o combate à fome e à miséria nos países subdesenvolvidos, aprimoraram as estratégias de crescimento da produção agrícola em nível mundial (OCTAVIANO, 2010).

No Brasil, a agricultura é retratada desde o período pré-colonial, quando os indígenas praticavam a agricultura de subsistência, e evoluindo para o período contemporâneo, onde predomina a tecnologia e a mecanização (BARBOSA, 2004). Com o objetivo de promover o desenvolvimento da agricultura, foram introduzidas técnicas aprimoradas de cultivo, mecanização, uso de fertilizantes, defensivos agrícolas e as sementes tradicionais que eram menos resistentes aos defensivos agrícolas foram substituídas por sementes de alto rendimento.

Esse período de transformações na agricultura, conhecido como Revolução Verde ${ }^{3}$, teve, dentre as principais características, o abandono da rotação de cultivos e do controle biológico. O solo passou a ser empregado apenas como suporte de plantas, não havendo mais a preocupação com a preservação do ambiente, da fauna e flora, e o que outrora era cultivado apenas para sustento básico, passou a requerer alto investimento de capital, bem como de maquinários e tecnologia. Concomitante a isso, para o controle de pragas e doenças, iniciou-se a utilização de defensivos agrícolas industriais cada vez mais potentes.

Dados os objetivos lucrativos da sociedade capitalista, o surgimento de técnicas avançadas para cultivo de produtos agrícolas fez com que aumentasse ainda mais a dependência dos países em desenvolvimento em relação aos países mais ricos, os quais detêm poder sobre a tecnologia indispensável ao cultivo das novas sementes, bem como, são os principais fornecedores de insumos que viabilizavam maior produtividade (CARDOSO, 2011).

A Revolução Verde representou um aumento significativo na produção agrícola, tanto mundial, quanto nacional, onde foi possível verificar a expansão da produção agrícola, até mesmo em áreas desacreditadas, como a do cerrado. A adoção de tecnologias voltadas a agricultura, possibilitou ao Brasil o crescimento impressionável, sendo representativo no cenário mundial (Figura 1).

\footnotetext{
${ }^{3}$ A Revolução Verde foi proposta por Norman Borlaug para a rápida expansão da produção de grãos (leguminosas e cereais) no mundo, sobretudo a partir das décadas de 1960 e 1970, seguindo-se dos itens referentes a frutas, verduras e pastagens cultivadas (BORLAUG, 1994).
} 
Figura 1 - Evolução da produção de grãos e área plantada no Brasil - 1976/77- 2016/17.

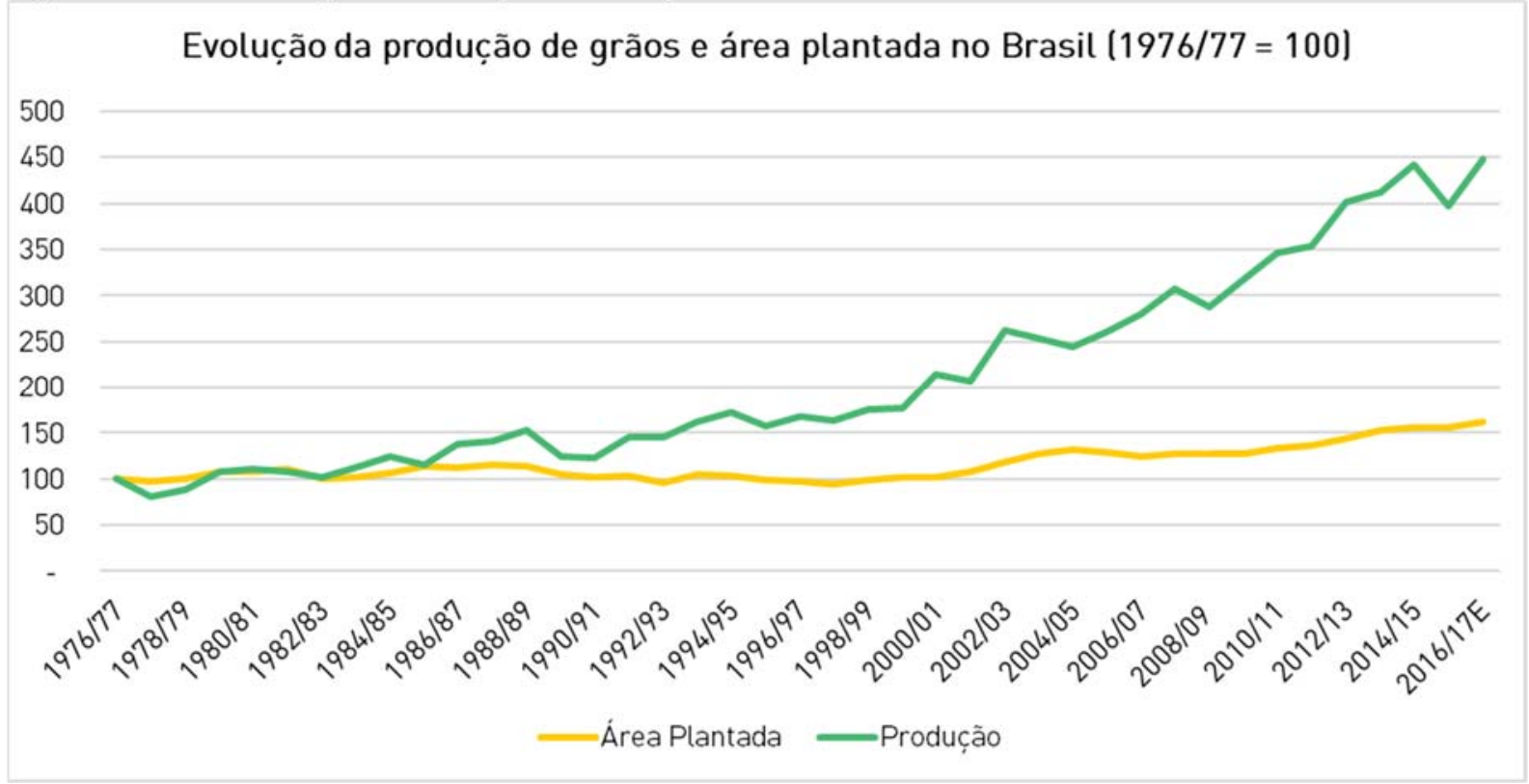

Fonte: PERFARM, 2017.

Esse crescimento na agricultura brasileira, influencia diretamente em outros setores interligados ao agronegócio, permitindo a geração de empregos e desenvolvimento econômico (PERFARM, 2017). Esse desenvolvimento produtivo no Brasil corresponde a um crescimento médio de 3,6\% por ano ao longo de 35 anos, entretanto, essa produção se manteve concentrada em poucas propriedades, onde $10 \%$ dos estabelecimentos respondem a $85 \%$ do valor bruto produzido.

Pesquisas internacionais como a do Departamento de Agricultura dos Estados Unidos têm apontado recentemente que a agropecuária brasileira é um das que apresenta maior ritmo de crescimento no mundo, com aumento de 4,28\% ano, ficando à frente de potencias mundiais, como a China e os Estados Unidos (BRASIL, 2017a). Um dos principais fatores para esse aumento é a alta produtividade das lavouras, em especial de algodão, milho e soja, esses últimos com perspectivas de recorde na produção (BRASIL, 2017b).

A principal motivação para esse crescimento está atrelada a estabilização econômica após a década de 1990, impulsionado por oferta de crédito e programas governamentais e ao avanço tecnológico que propiciou a maior utilização de insumos e fertilizantes. Estudos demonstram que a manutenção dessas políticas, proporcionou o avanço do agronegócio (WILKINSON, 2010).

A produtividade agrícola é um determinante importante na economia do país, onde no Brasil foi impulsionada pela melhoria no processo de produção, como os avanços tecnológicos, melhoria na gestão e insumos de melhor qualidade. Diversas empresas multinacionais têm 
aumentado seus investimentos no Brasil, faturando bilhões a cada ano, com progressão de aumento maior que o PIB nacional. Esse patamar histórico de superprodução ao longo de anos expõem a importante contribuição do agronegócio na economia brasileira, no sentido de geração de emprego e renda, e principalmente na estabilidade macroeconômica do país, em virtude do faturamento, o que ajuda a amenizar o déficit comercial oriundo de outros setores produtivos. No que se refere aos principais destinos da exportação estão: a China, consolidandose como a principal parceira; a Zona do Euro e os Estados Unidos; seguidos de Japão, Rússia, Arábia Saudita, Coréia do Sul, Venezuela, Hong Kong e Irã (AGROANALYSIS, 2014).

Em um patamar maior que abrange a produção agrícola dos países da América Latina, indicadores do Inter-American Development Bank (IADB) apontam um crescimento de 80\% até 2050 no cenário agrícola, para atender a um esperado aumento na sua população, mais de $35 \%$ no mesmo período. Nessa região, os pobres gastam entre $50 \%$ e $80 \%$ de sua renda em alimentos, e quase $2 / 3$ da população rural total ainda vive na pobreza (IADB, 2014). Essa disparidade social é o grande motivo de intensos conflitos nesses países, originando diferentes propostas de reformas agrarias, propondo uma melhor distribuição de terras, a citar o caso do México, Cuba, Peru e Chile (AGROANALYSIS, 2014). Entretanto, embora haja esse cenário conflituoso, de maneira geral a América latina e o Caribe são destaques no cenário mundial por serem a maior região exportadora de alimentos do mundo, onde quase o total dessa produção é destinado a exportação.

Grandes incentivadores desses avanços são os organismos internacionais como o IADB que investem em infraestrutura rural, como construção e a reabilitação da irrigação, drenagem e controle de cheias além de infraestrutura regional ou nacional, como estradas rurais, eletrificação rural, água rural (para o desenvolvimento da pecuária), as quais contribuem para o aumento da produtividade e da produção alimentar regional (IADB, 2014).

No Brasil, o incentivo a produção agrícola acontece por meio da liberação de créditos de custeio, de investimento ou de comercialização, disponibilizados pelo governo federal mediante cooperativas de crédito ou por intermédio dos bancos, ambos financiados pelo Banco Nacional de Desenvolvimento Econômico e Social (BNDES), assim como pelos Fundos Constitucionais de Financiamento. Essa transferência de recursos aos produtores rurais ajuda a garantir certo nível de renda para os agricultores, visto que esses programas também podem ser usados como política para aumentar a produtividade, ampliar as transferências condicionais de renda para a adoção de tecnologias por meio da melhor gestão das propriedades rurais.

Outro aliado no aumento da produtividade atual é a digitalização do campo, que assim como a Revolução Verde, marca o início de uma nova era na agricultura, a Revolução Digital. 
Embora seja um dos setores menos digitalizados, a proposta envolve redução de custos de processos feitos manualmente, o controle e predição de novos processos que levam em consideração a infinidade de variáveis presentes na produção agrícola, além de possibilitar a análise mais criteriosa e detalhada do solo e dos produtos, permitindo a aplicação variável e otimização do uso de recursos (PERFAM, 2017).

Além desses benefícios que resultam em produtividade, tornando o agronegócio brasileiro ainda mais competitivo, o controle de pragas e o desperdício de insumos agrícolas, pode resultar em uma menor aplicação de agrotóxicos, sendo importante para o meio ambiente global.

É possível observar, no que se refere a agricultura como base econômica do país, muitas dificuldades a serem superadas para que o Brasil se consagre como destaque mundial, e competir com outras potências na produção e exportação, estando entre elas, as dificuldades com a precariedade do transporte rodoferroviário, o armazenamento da produção, e o sistema governamental, ainda com pouco investimento e muitas taxas tributárias, encarecendo o custo da produção, e dificultando a competitividade do Brasil a nível mundial (PERFAM, 2017).

O último levantamento referente a safra de 2019/2020, elaborado em junho de 2020, confirmou o crescimento da produção de grãos no país, recorde, estimada em 250,5 milhões de toneladas, 3,5\% ou 8,5 milhões de toneladas, superior ao colhido em 2018/19. Com a área das culturas de primeira safra praticamente colhida, e as de segunda em andamento, ainda depende da conclusão do plantio das culturas de inverno e do comportamento climático, que pode influenciar na produtividade destas culturas. Para a obtenção desse resultado, a área semeada totaliza 65,6 milhões de hectares, o que representa um crescimento de 3,6\% ou 2,3 milhões de hectares, sobre a da safra passada. Entre os produtos, a soja e o milho segunda safra, tiveram produção recorde quando comparadas à safra 2018/19 (CONAB, 2020).

Segundo o CONAB (2020), os estados de Mato Grosso, Paraná, Goiás e Rio Grande do Sul são, respectivamente, os líderes em produção (Figura 2). 
Figura 2 - Distribuição da Produção total no Brasil por estados (em mil toneladas) - Safra 2019/2020.

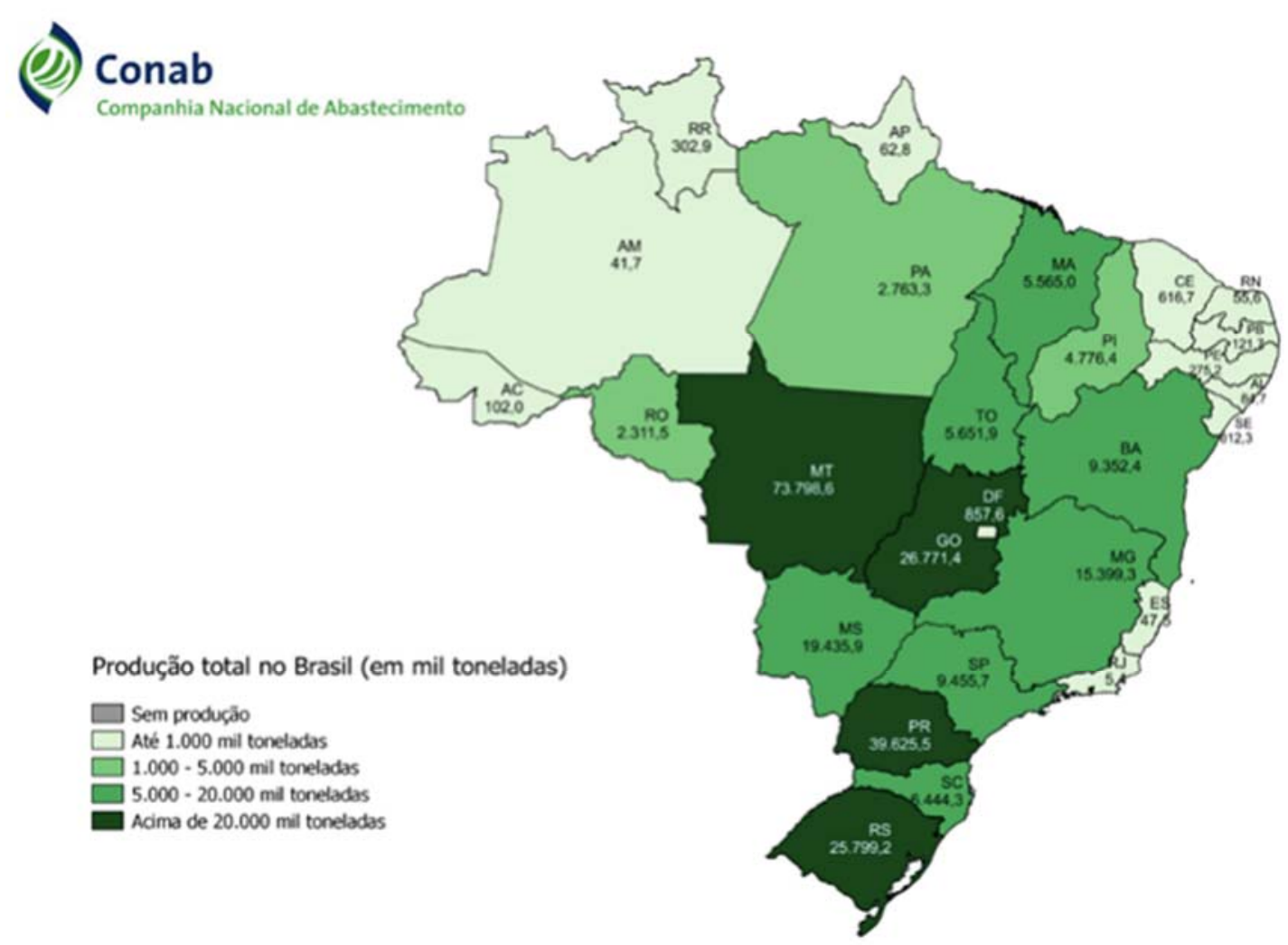

Fonte: CONAB (2020).

Outro fator notável é que a agricultura se manteve forte em meio a crise, política e econômica que o país vem vivendo, entretanto, embora seja a melhor em produção econômica, ainda não é o setor que mais abriga a mão de obra. A migração da força de trabalho do campo para a indústria fez com que o impacto da crise, atingisse mais fortemente a população.

Diante de tudo isso, é notável que a capacidade competitiva da agropecuária brasileira, com pretensão de crescimento da produção de forma sustentável, tem colocado em destaque o debate sobre o agronegócio brasileiro e o desenvolvimento sustentável. Entretanto, concomitante à significativa produção, os dados estatisticamente oficiais da ANVISA e do Instituto Brasileiro do Meio Ambiente e dos Recursos Naturais Renováveis (IBAMA) alertam que o Brasil também ocupa o posto de maior consumidor de agrotóxico mundialmente desde 2008. Na última safra estimada, que envolve o segundo semestre de 2016 e o primeiro semestre de 2017, o mercado nacional de venda de agrotóxicos movimentou mais de 500 mil toneladas de produtos. Esses dados são apresentados pelo IBAMA nos boletins anuais de consumo de agrotóxicos, a partir de dados fornecidos pelas empresas registrantes de produtos técnicos, 
agrotóxicos e afins, que em uma perspectiva longitudinal indica que de 2000 a 2016 o consumo quintuplicou (IBAMA, 2018).

Tão alarmante quanto esses dados, são as estimativas, que indicam que em safras futuras o Brasil permanecerá liderando o ranking mundial no consumo de agrotóxicos, contaminando águas continentais e oceânicas, solos e plantas, animais terrestres e aquáticos e pessoas de todas as idades com os efeitos nocivos de seu manejo, inalação e ingestão (IBAMA, 2018). É importante relatar, que os dados obtidos a partir dos levantamentos do IBAMA não consideram os produtos admitidos no Brasil por meio de tráfico e contrabando, sendo outro grande alarmante para o meio ambiente e saúde humana.

O contrabando e a falsificação de produtos é um problema que vem se expandindo atualmente, e nos últimos anos, esta atividade ilegal passou a incluir o mercado de defensivos agrícolas do Brasil. Geralmente esses produtos contrabandeados tem origem em países vizinhos, de exportação como da China, ou até mesmo produzidos caseiramente. O reconhecimento destes produtos pode ser feito por meio das embalagens que vem com inscrições em outros idiomas, não ofertam os riscos do produto e são comercializados a baixos preços. O crime para os agentes deste negócio, vai desde a caracterização do próprio contrabando ou descaminho, até crime ambiental, por fornecer e distribuir um produto sem as dimensões de risco que a envolvem (DORFMAN; FRANÇA; SOARES, 2014).

Os impactos que o contrabando de defensivos agrícolas na economia brasileira gera são difíceis de serem mensurados, entretanto, em 2016 Associação Brasileira das Indústrias Químicas lançou nota afirmando que no Brasil, mais de $20 \%$ dos agrotóxicos usados são falsificados ou contrabandeados, movimentando no comércio cerca de R $\$ 7$ bilhões por ano, e demonstrando que os impactos dos produtos agrotóxicos abrangem dimensões maiores do que já imaginadas (ALTAFIN, 2016).

Outro preocupante são os produtos geneticamente modificados, chamados transgênicos, ocupam de 8 a 10\% da agricultura mundial. No Brasil, esses produtos têm se proliferado a uma velocidade assustadora e descontrolada, defendida pela agricultura como alternativa eficaz de aumento na produtividade e confrontada pelos órgãos de saúde e meio ambiente, como um produto inseguro, cujos efeitos a longo prazo ainda são questionáveis. Após sua implantação nacional, a cerca de 22 anos, essa tecnologia altamente mutagênica, que traz a combinação de genes que não ocorrem normalmente na natureza, alterando a bioquímica da planta (ISSAA, 2017; GARRO-MONGE, 2017).

Os estudos experimentais com produtos transgênicos ainda não são suficientes para confirmar a segurança de seu cultivo e consumo, e por outro lado, outros estudos que investigam 
seus efeitos deletérios tem demonstrado que essas mudanças nos alimentos podem estar gerando riscos para o agronegócio, pois torna o produtor rural dependente das empresas fornecedoras dos produtos, para o meio ambiente, causando a resistência e até mesmo a mutação de pragas e ervas-daninhas, mas principalmente para a saúde, manifestado por meio do aumento a alergias em crianças, aumento da resistência de antibióticos, e aumento da quantidade de resíduos de agrotóxicos (ALTIERI et al., 2000; NODARI; GUERRA, 2001; PALEAZ; ALBERGONI, 2004; POMIECINSKI et al., 2017)

De acordo com as regras nacionais atuais, os responsáveis pelas análises dos novos agrotóxicos são os órgãos dos Ministérios da Agricultura, Saúde e Meio Ambiente, trabalho que normalmente leva mais de cinco anos, entretanto, circula desde 2002 um projeto na Câmara dos Deputados que pretende reduzir esse prazo para 12 meses, obtendo então o registro provisório (BRASIL, 2018a). Além disso, a sugestão de alteração na nomenclatura, passando de "Produto Agrotóxicos" para "Produto Fitossanitário", uma tentativa de amenizar o impacto, que o próprio nome sugere, e a facilitação de liberação de produtos com características teratogênicas, causadoras de anomalias de útero e malformação no feto, e cancerígenas ou mutagênicas (BRAGON, 2018).

Esses dados demonstram uma permissividade brasileira sobre o uso de agrotóxicos, o qual permite o uso de 504 tipos de agrotóxicos, 30\% destes proibidos em outras regiões do mundo, como a União Europeia, alguns há mais de uma década. Também é possível notar que em pouco mais de dez anos, mais que dobrou o uso desses venenos na agricultura brasileira, saltando de 3,1 Kg/há, em 2001 para 6,8 Kg/há, em 2013, representando no total um aumento de 288\% no uso de agrotóxicos (CARNEIRO, 2015; BOMBARDI, 2017).

A Associação Brasileira de Saúde Coletiva (ABRASCO) fez também um documento apontando problemas com o uso abusivo de agrotóxicos. Chamado "Impactos dos Agrotóxicos na Saúde", o dossiê reafirma que os agrotóxicos fazem mal à saúde das pessoas e ao meio ambiente, comprovado por meio de índices e notificações do Ministério da Saúde sobre intoxicações dos produtos agrícolas. Além disso, a ANVISA ainda confirma a intoxicação de $64 \%$ dos alimentos por agrotóxicos. 


\subsubsection{A agricultura no Estado do Paraná e os casos de intoxicação agrícola}

O Paraná é um dos 26 estados do Brasil que compõem a região $\mathrm{Sul}^{4}$. O clima apresenta diferenças marcantes, dependendo da região - de tropical úmido ao norte a temperado úmido ao sul. A população é formada por descendentes de várias etnias: poloneses, italianos, alemães, ucranianos, holandeses, espanhóis, japoneses e portugueses, e por imigrantes procedentes, em sua maioria, dos estados do Rio Grande do Sul, Santa Catarina, São Paulo e Minas Gerais (Figura 03).

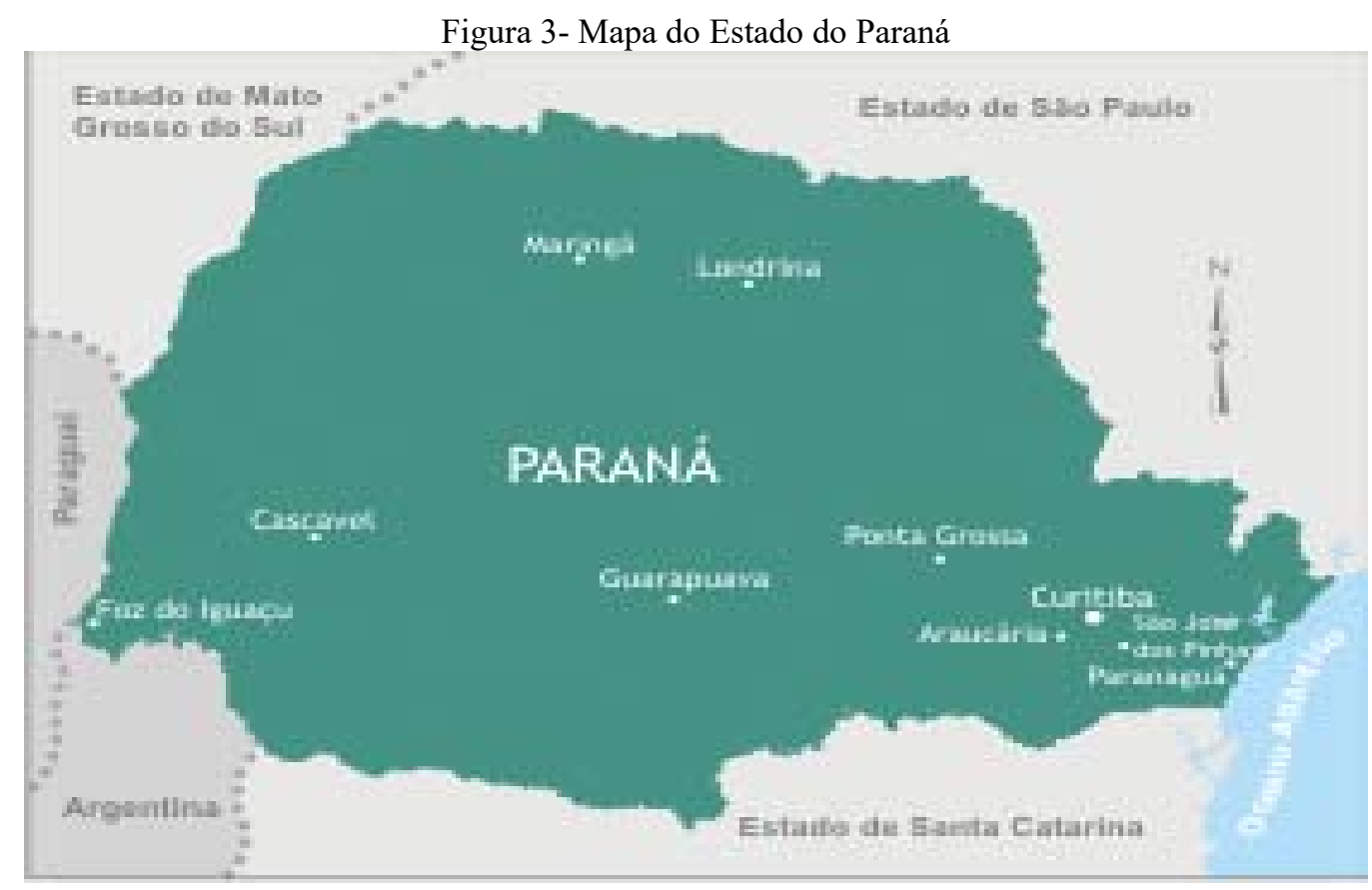

Fonte: site IPARDES, 2013

Segundo dados do Instituto Paranaense de Desenvolvimento Econômico e Social (IPARDES), o Paraná ocupa $199.880 \mathrm{~km}^{2}$ de área, com densidade demográfica de 55,02 de habitantes por $\mathrm{km}^{2}$ (dados de 2013), possui 399 municípios, e segundo último senso realizado em 2010 pelo Instituto Brasileiro de Geografia e Estatística (IBGE) a população é de 10.444.526, representando 5,5\% da população brasileira que é de 190.755 .799 pessoas. A área urbana representa 85,3\% do território e o Índice de Desenvolvimento Humano (IDH) é de 0,749 (quinto lugar no ranking brasileiro), acima da média nacional que é de 0,727 (2010) o que pode

\footnotetext{
4 Faz divisa com os estados de São Paulo, Santa Catarina e Mato Grosso do Sul, fronteira com a Argentina e o Paraguai e limite com o Oceano Atlântico. Sua capital é Curitiba, e outras importantes cidades são Londrina, Maringá, Foz do Iguaçu, Ponta Grossa, Cascavel, Guarapuava e Paranaguá.
} 
ser considerado um índice alto nos critérios de avaliação (IPARDES, 2016, 2020; IBGE, 2019)..$^{5}$

Referente a agricultura, embora uma característica do Paraná seja a formação fundiária baseada em pequenas propriedades, sua área de cultivo possui elevadas taxas de produtividade. Isso porquê o solo é bastante fértil e a topografia é famosa por ser adequada às mais variadas culturas. Essas características transformou o estado em um dos principais pontos de atividade agrícola a nível nacional, conhecida pela produção em larga escala de frutas, legumes e verduras (IPARDES, 2016; 2020).

A economia paranaense é a quinta maior do País. O Estado responde atualmente por 6,4\% do PIB nacional, registrando uma renda per capita de R\$ 35,7 mil em 2016 (IBGE, 2019).

A agropecuária do Paraná teve em 2017 o melhor desempenho em quatro anos, correspondendo a 9,8\% do PIB do Estado em 2017. A safra recorde de grãos e o bom resultado da pecuária fizeram o Produto Interno Bruto (PIB) do setor crescer 11,5\% no ano passado, adicionando a economia $\mathrm{R} \$ 35,9$ bilhões referente a agropecuária.

O Paraná se destacou nas principais culturas em 2017, resultado do equilíbrio entre as novas tecnologias aplicadas ao campo e a colaboração climática. De acordo com números do IBGE, respondeu por $17,2 \%$ da produção de soja, 18,4\% de milho, 52,2\% de trigo, $21,7 \%$ de feijão, $57,9 \%$ de cevada, $71,4 \%$ de centeio, $21,7 \%$ de aveia e $1,3 \%$ de arroz.

Embora os líderes econômicos do estado estejam ligados à indústria, comércio, serviços e energia, a agricultura ganha destaque em virtude do posto que o Paraná ocupa nacionalmente, entre os maiores produtores de grãos e por apresentar uma pauta agrícola diversificada.

Nas últimas estimativas do IBGE sobre a produção agrícola paranaense, é possível notar que na produção de 2019 destacou-se o cultivo da cana-de-açúcar, seguido da soja. Os órgãos responsáveis por esses levantamentos, alegam que o clima associado aos valores pagos aos produtores são determinantes nas oscilações de áreas plantadas nos cultivos (IPARDES,

5 O Desenvolvimento Humano é o processo de ampliação das liberdades das pessoas, no que tange suas capacidades e as oportunidades a seu dispor, para que elas possam escolher a vida que desejam ter. O Índice de Desenvolvimento Humano (IDH) é um dado utilizado pela Organização das Nações Unidas (ONU) para analisar a qualidade de vida de uma determinada população. Esse índice é obtido a partir da reunião dos três requisitos mais importantes para a expansão da liberdade das pessoas: a oportunidade de se levar uma vida longa e saudável - saúde -, ter acesso ao conhecimento - educação - e poder desfrutar de um padrão de vida digno - renda. O Índice de Desenvolvimento Humano varia de 0 a 1, quanto mais se aproxima de 1, maior o IDH de um local (PNUD, 2013). 
2020). Os agricultores tendem a acompanhar o desenvolvimento do mercado econômico, reduzindo e/ou aumentando áreas para produções que tendem a fornecer mais lucros.

Figura 4 - Distribuição da produção agrícola paranaense em 2019

Produção por ano da safra e produto (Toneladas), maio 2019

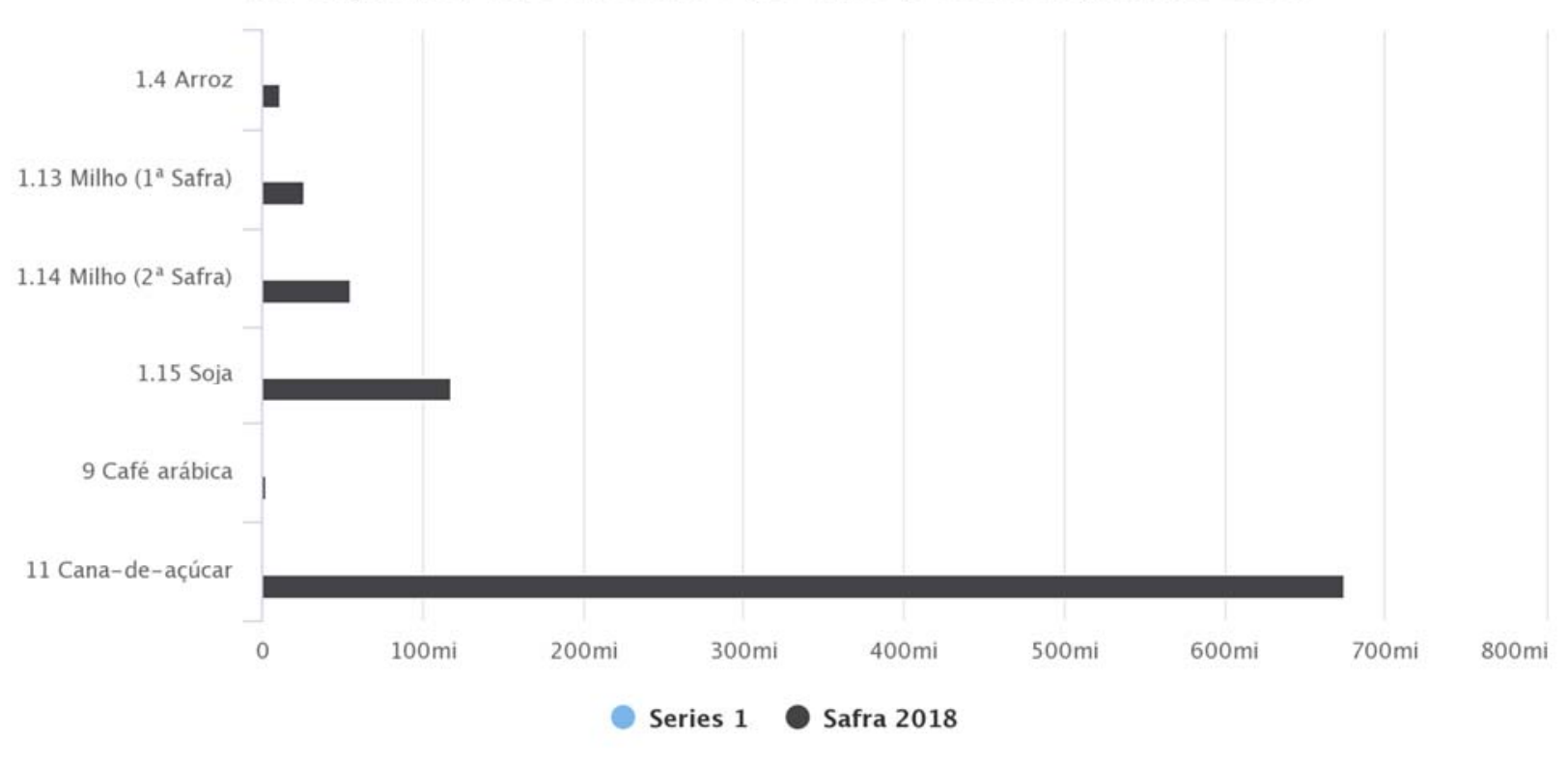

Fonte: IBGE (2019).

Fonte: "IBGE - Levantamento Sistemático da Produção Agrícola"

Concomitante ao destaque em produção agrícola, o Paraná também é destaque em consumo de agrotóxicos, sendo o terceiro maior consumidor do Brasil. O volume total de agrotóxicos consumidos foi de $97.714 .800 \mathrm{~kg}$ no ano de 2014 e $100.122 .700 \mathrm{~kg}$ em 2015 (PARANÁ, 2016). A média de consumo por hectare foi acima da média para 159 municípios (40\%), com destaque para Braganey com 39,2 kg/ha, Corbélia com 37,4 kg/ha e Brasilândia do Sul, 35,5 kg/ha. 
Figura 5 - Comparação da área plantada x consumo de agrotóxicos em 2015 no Paraná

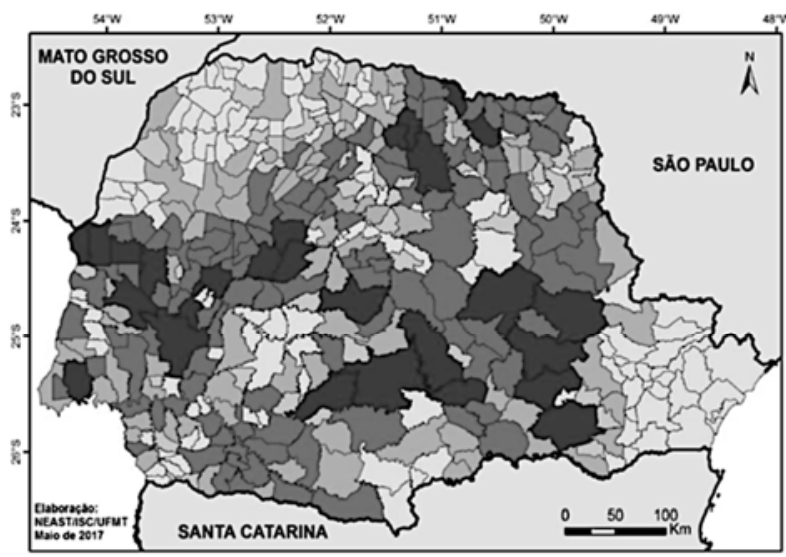

Área plantada em hectares nos municipios do Paraná, 2015 $\square$ 40.0 a $11.399,9$ (130) $\square 11.400,0$ a $14.773,0$ (41) $\square 14.773,1$ a $26.132,9$ (91) $\square 26.133,0$ a $64.390,6(110) \quad \square 64.390,7$ a $193.234,0$ (27)

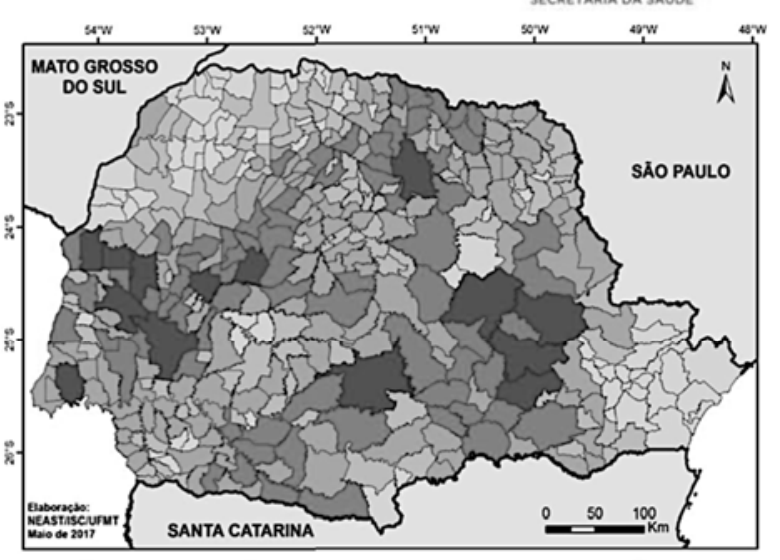

Consumo de agrotóxicos em litros nos municipios do Paraná, 2015

$\square$ 349,0 a 66.288,4 (77) $\square$ 66.288,5 a 207.925,3 (105) $\square$ 207.925,4 a 512.159,1 (131) $512.159,2$ a $1.165 .648,8(72) \square 1.165 .648,9$ a $2.569 .335,0$ (14)

Fonte: Paraná/SIAGRO 2017.

Acerca das intoxicações, no Paraná, as notificações das "intoxicações por inseticidas" estão previstas desde 1975, na primeira versão do Código Sanitário do Estado. Em 2001, com a edição do novo Código Sanitário, todos os acidentes toxicológicos passaram a ser de notificação compulsória (PARANÁ, 2018). A partir de 2007, o registro dessas ocorrências foi incluído na Ficha de Notificação das Intoxicações Exógenas no Sistema de Informação de Agravos de Notificação (SINAN), devendo o agrotóxico ser classificado como de uso agrícola, uso doméstico ou uso em saúde pública.

Em dados atualizados em 2019 encontrados no SINAN referente as intoxicações exógenas, com o agente agressor “Agrotóxico Agrícola” no período de 2001 a 2017 é possível verificar que o índice de notificações foi consideravelmente inferior quando comparado aos dados levantados pela Secretaria do Estado do Paraná. Estes dados ainda estão em construção e podem sofrer alterações ao longo do ano, mas evidenciam um número de notificações superior aos demais anos anteriores (IPARDES, 2020).

Tabela 1 - Intoxicações Exógenas - Notificações registradas no Sinan Net - Brasil

Agente Tóxico: Agrotóxico agrícola - Período:2017

\begin{tabular}{cc}
\hline Ano $1^{\circ}$ Sintoma(s) & Notificações \\
\hline 2001 & 1 \\
\hline 2016 & 10 \\
\hline 2017 & 637 \\
\hline Total & 648
\end{tabular}

Fonte: Ministério da Saúde/SVS - Sistema de Informação de Agravos de Notificação - Sinan Net. Acesso em julho de 2019. 
No período de 2012 a 2016, foram registradas no SINAN NET 4.190 ocorrências de intoxicação por agrotóxicos, sendo que $72,6 \%$ dos casos foram por agrotóxicos de uso agrícola. Os casos de intoxicação por agrotóxicos de uso doméstico representam $24,4 \%$ e os agrotóxicos de uso em saúde pública, 3\%. Destacam-se com o maior número de notificações os grandes centros populacionais do Estado, as regionais de saúde Metropolitana, Londrina, Maringá e Cascavel. Chamam a atenção regionais com número significativamente alto de notificações como Irati, Pato Branco, Apucarana e Guarapuava, contrastando com as regionais de Toledo, Telêmaco Borba, Ivaiporã e Jacarezinho pelo número reduzido de notificações, dada a economia local baseada em agricultura e pecuária.

A faixa etária que mais se intoxica situa-se entre 20 e 49 anos, predominantemente do sexo masculino, que corresponde à faixa etária em idade produtiva, representando $59,5 \%$ do total. As crianças e adolescentes até 14 anos somam 12,7\% dos casos notificados. E os jovens entre 15 e 19 anos representam 10\% das notificações (Figura 6).

Figura 6 -Percentual de Frequência de casos notificados de intoxicação por agrotóxico segundo faixa etária - 2012 a 2016

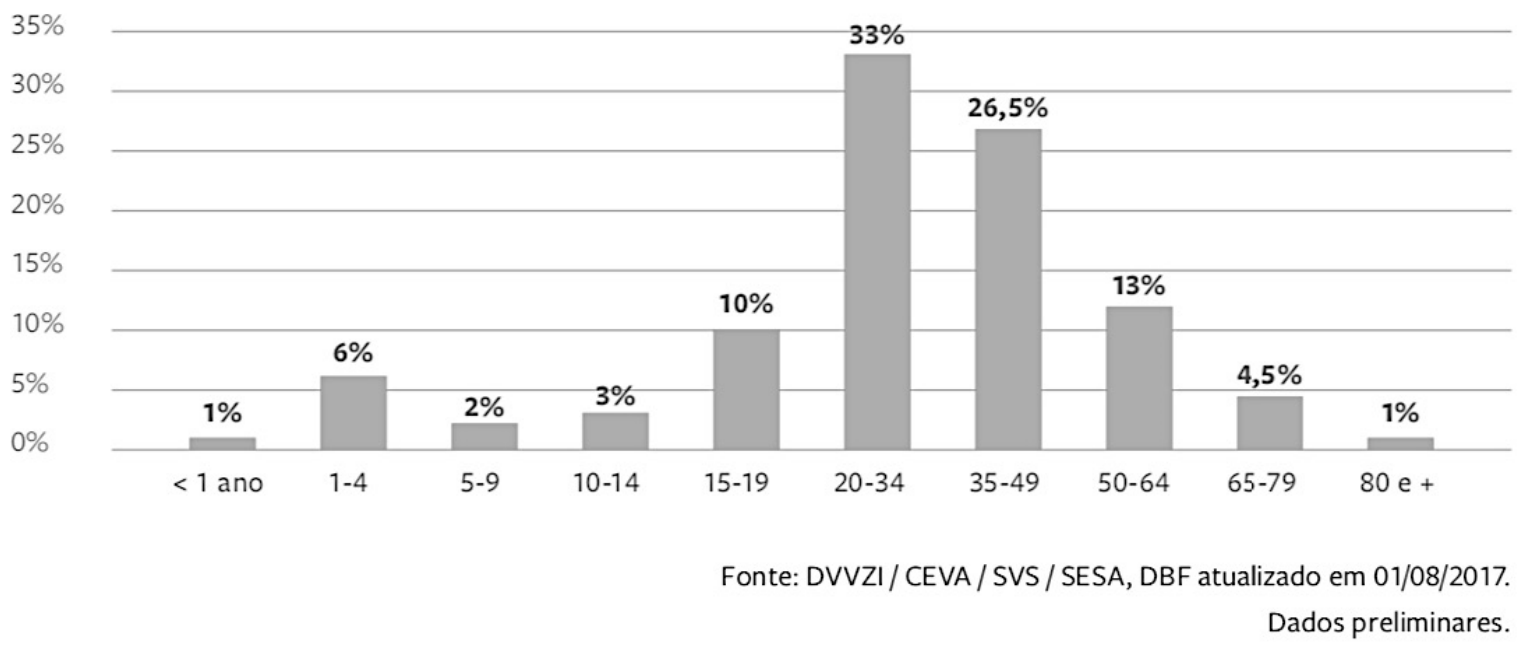

Fonte: DVVZI/CEVA/ SVS/SESA, DBF atualizado em agosto de 2017 - Dados preliminares.

Em relação à circunstância de exposição, a acidental (40,8\%) e a tentativa de suicídio $(38,5 \%)$ são as mais notificadas; em menor número estão as relacionadas com o trabalho $(28,4 \%)$. E a residência é o local onde ocorre o maior número de intoxicações por agrotóxicos $(63,3 \%$ dos casos). 
Quando se analisa o modo de exposição pelo qual ocorreu a intoxicação, a via digestiva é a mais citada, em 53\% das notificações, coerente com as circunstâncias de contaminação acidental, em crianças, e as tentativas de suicídio, nos adultos. Em seguida, as vias respiratórias $(27,3 \%)$ e cutânea $(16,2 \%)$ têm importante notificação, apontando para as intoxicações relacionadas ao trabalho (Figura 7).

Figura 7 - Percentual de Frequência de casos notificados de intoxicação por agrotóxico segundo a via de exposição -2012 a 2016

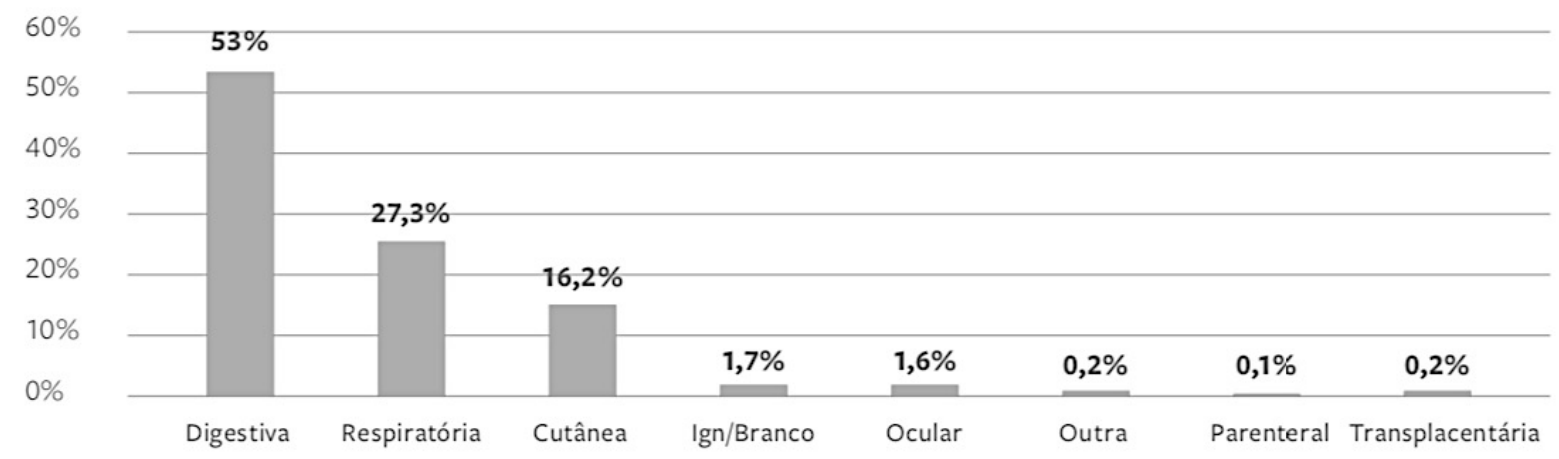

Fonte: DVVZI/CEVA/ SVS/SESA, DBF atualizado em agosto de 2017 - Dados preliminares.

Neste sentido, o processo de saúde e doença dos trabalhadores está diretamente ligado às condições em que o trabalho é realizado, seus processos e organização. Por saúde do trabalhador, compreendem-se um corpo de práticas teóricas interdisciplinares, técnicas, sociais, humanas e interinstitucionais desenvolvidas por diversos atores situados em lugares sociais distintos e informados por uma perspectiva comum (PARANÁ, 2011).

Os efeitos dos produtos agrotóxicos em geral já foram identificados por biólogos e cientistas, e remetem-se a compactação dos solos, erosão, diminuição da fertilidade dos solos, da biodiversidade, contaminação dos solos e das águas por nitratos e agrotóxicos, aparecimento de pragas resistentes aos agrotóxicos, aparecimento de novas pragas, entre outros, causando o desequilíbrio ambiental. Mas, não somente à natureza são observadas alterações, como também está preocupando os profissionais da saúde pública a ocorrência de contaminação dos alimentos e dos seus consumidores, além das intoxicações crônicas e agudas dos trabalhadores rurais, razões pelas quais, entre muitos outros, este estudo está sendo realizado como instrumento de observação de anomalias congênitas e outras adversidades que ocorrem aos recém-nascidos, cujas mães residem em áreas agrícolas (BATISTA; FILHO; MELO, 2012).

Após o lançamento da Portaria 2938/2012, pelo Ministério da Saúde (MS), instituindo a Vigilância em Saúde de Populações Expostas a Agrotóxicos, a Secretaria de Estado da Saúde 
do Paraná (SESA-PR) elaborou e implantou o Plano Estadual de Vigilância das Populações Expostas aos Agrotóxicos 2013-2016, contendo 14 ações estratégicas. No início de 2017, durante a avaliação do Plano 2013-2016, somada à demanda crescente por oferta de serviços ou pontos de atenção, a SESA-PR optou por incluir a assistência à saúde nessa discussão, com foco na exposição e intoxicação por agrotóxico, surgindo o Plano Estadual de Vigilância e Atenção à Saúde das Populações Expostas aos Agrotóxicos 2017-2019 (PEVASPEA-PR), com 20 ações estratégicas, cujo ineditismo é ter em seu escopo orientações à assistência na forma de uma Linha Guia.

A concretização de uma Linha Guia pretende subsidiar tecnicamente os profissionais da rede de atenção primária para o acolhimento, diagnóstico, tratamento, notificação e acompanhamento da saúde dos trabalhadores e população exposta aos efeitos agudos e crônicos dos agrotóxicos no Estado do Paraná. Além disso, a proposta visa garantir a essas pessoas uma rede de assistência com atendimento qualificado nas Atenções Primária, Secundária e Terciária e nos serviços de Urgência/Emergência, permitindo aos paranaenses uma saúde de qualidade.

\subsubsection{Agrotóxicos: definição, classificação e o impacto no manuseio.}

A Agência Nacional de Vigilância Sanitária (ANVISA) é uma autarquia sob regime especial, que tem como área de atuação todos os setores relacionados a produtos e serviços que possam afetar a saúde da população brasileira. Com a responsabilidade de coordenar as ações na área de toxicologia no Sistema Nacional de Vigilância Sanitária, seu principal objetivo é regulamentar, analisar, controlar e fiscalizar produtos e serviços que envolvam riscos à saúde agrotóxicos, componentes e afins e outras substâncias químicas de interesse toxicológico (BRASIL/ANVISA, 1999).

Os agrotóxicos são definidos pela Lei № 7.802, de 11 de julho de 1989, que dispõe sobre a pesquisa, a experimentação, a produção, a embalagem e rotulagem, o transporte, o armazenamento, a comercialização, a propaganda comercial, a utilização, a importação, a exportação, o destino final dos resíduos e embalagens, o registro, a classificação, o controle, a inspeção e a fiscalização de agrotóxicos, seus componentes e afins além de tratar de outras providencias (BRASIL, 1989).

Segundo essa lei considera-se agrotóxicos e afins como: 
agrícolas, nas pastagens, na proteção de florestas, nativas ou implantadas, e de outros ecossistemas e também de ambientes urbanos, hídricos e industriais, cuja finalidade seja alterar a composição da flora ou da fauna, a fimm de preservá-las da ação danosa de seres vivos considerados nocivos; substâncias e produtos, empregados como desfolhantes, dessecantes, estimuladores e inibidores de crescimento (BRASIL, 1989, p.1).

Em relação à classificação, os agrotóxicos são categorizados de diversas formas, sendo as principais de acordo com o modo de ação no organismo alvo, em relação à sua estrutura química, e quanto aos efeitos que causa à saúde humana, pela avaliação da neurotoxicidade.

A ANVISA por meio de testes laboratoriais definiu critérios para a classificação toxicológica, sendo enquadrados de acordo com a Dose Letal (DL) em:

Tabela 2 - Classificação Toxicológica de acordo com a Dose Letal (DL).

\begin{tabular}{cccc}
\hline Classe & Grupos $^{6}$ & DL50 $(\mathbf{m g} / \mathbf{k g})$ & Cor da faixa \\
\hline I & Extremamente tóxico & $\leq 5$ & Vermelha \\
II & Altamente tóxico & $5-50$ & Amarela \\
III & Mediamente & $50-500$ & Azul \\
IV & Tóxico Pouco Tóxico & $50-5000$ & Verde \\
\hline
\end{tabular}

A classificação dos agrotóxicos segundo o seu grau de toxidade para o ser humano é fundamental, pois fornece a toxidade desses produtos relacionados com a Dose Letal 50 (DL50\%). A DL 50 ou dose letal média de uma substância expressa o grau de toxicidade aguda de substâncias químicas. Correspondem às doses que provavelmente matam 50\% dos animais de um lote utilizados para experiência. São valores calculados estatisticamente a partir de dados obtidos experimentalmente.

Com base nas DL50 de várias substâncias, são estabelecidas classes toxicológicas de produtos químicos e farmacológicos, no entanto, para que uma substância seja considerada tóxica ou inócua para o ser humano, critérios devem ser considerados para avaliar se uma substância oferece Risco ou Perigo para um determinado sistema biológico, para um determinado indivíduo ou para a saúde pública.

\footnotetext{
${ }^{6}$ A Lei n ${ }^{\circ} 7802$, de11 de julho de 1989, também dispõe que os rótulos deverão conter uma faixa colorida indicativa de sua classificação toxicológica. Sendo: Classe I: Faixa vermelha- Extremamente tóxico; Classe II: Faixa amarelaAltamente Tóxico; Classe III: Faixa Azul-Mediamente Tóxico; Classe IV: Faixa verde - Pouco Tóxico.
} 
Quanto ao modo de ação do ingrediente ativo no organismo alvo ou à natureza da praga combatida, os agrotóxicos são classificados como inseticidas, fungicidas, herbicidas, rodenticidas e/ou raticidas, acaricidas, nematicidas, fumigantes, moluscicidas etc. (SAVOY, 2011).

Os mais usados comumente são os inseticidas, utilizados no combate a insetos, larvas e formigas. Possuem efeito cumulativo, por isso, ao invés de se diluírem, vão aumentando sua concentração no ambiente (SÁ; CRESTANA, 2004). De acordo com a sua estrutura química esses compostos são classificados nos seguintes grupos: inseticidas de origem vegetal; inseticidas inorgânicos; inseticidas organossintéticos. Também são comumente usados os rodenticidas/raticidas usados no combate a ratos, os fungicidas para controle de doenças transmitidas por fungos na agricultura e os herbicidas para combater ervas daninhas.

Em todo o mundo, pesquisas científicas que se destinam a investigar os impactos que os agrotóxicos causam a saúde humana tem ganhado prioridade, particularmente nos países em desenvolvimento onde estes agentes químicos são amplamente utilizados na produção agrícola (PERES; MOREIRA; LUZ, 2007).

Em uma busca acadêmica a três diferentes bases de dados, com o descritor “agrotóxicos" são encontrados aproximadamente 4 mil publicações cientificas, e com o descritor intoxicação/intoxicações mais de 24 mil resultados, sendo grande parte dessas pesquisas relacionadas às intoxicações causadas diretamente com os produtos defensivos agrícolas ${ }^{7}$. Esse número surpreendente de pesquisas, em sua maioria, se restringe a investigar os efeitos dos agrotóxicos nos seres humanos e no ambiente, alertar acerca dos cuidados em relação a intoxicações, e até mesmo notificar esses casos, bem como discutir acerca de uma real preocupação dos possíveis males, principalmente em longo prazo, que esses produtos causam, e também propor métodos orgânicos, como solução e substituição aos produtos agrotóxicos (MONTICIELO et al., 2008; SOARES; PORTO, 2012; BURNS CJ, et al., 2013; SANTANA; MOURA; NOGUEIRA, 2013; NEVES; BELLINI, 2013).

A ANVISA não atua sozinha no monitoramento e divulgação de intoxicações, fazendo parte dela, o Sistema Nacional de Informações Tóxico-Farmacológicas (SINITOX) criado em 1980 e vinculado à Fundação Oswaldo Cruz (FIOCRUZ), é responsável pela coleta,

\footnotetext{
${ }^{7}$ Pesquisa realizada com o descritor “agrotóxicos" no portal de periódicos da Capes (1.956 publicações), nas bases de dados do Portal de Pesquisa da BVS (2.141 publicações) e na Scielo (654 resultados). Com o descritor “intoxicação / intoxicações" encontra-se no portal da Capes (1.948 resultados), no Portal de Pesquisa da BVS (22.880 publicações) e na Scielo (1.212). Pesquisa realizada na data de 13 de abril de 2020.
} 
compilação, análise e divulgação dos casos de intoxicação e envenenamento registrados pela Rede Nacional de Centros de Informação e Assistência Toxicológica (RENACIAT), coordenada pela ANVISA, composta de 36 unidades localizadas em 18 estados e no Distrito Federal, que possuem a função de fornecer informação e orientação sobre o diagnóstico, prognóstico, tratamento e prevenção das intoxicações, assim como sobre a toxicidade das substâncias químicas e biológicas e os riscos que elas ocasionam à saúde (RENACIAT, 2005).

O SINITOX considera, a partir de 1999, casos de intoxicação e envenenamento causados por 17 agentes tóxicos, dentre eles agrotóxicos que são categorizados em: agrotóxicos de uso agrícola, agrotóxicos de uso doméstico, produtos veterinários e raticidas (BOCHNER, 2007). Esta categorização é importante quando se deseja estudar o perfil de cada um desses agentes tóxicos.

No último levantamento realizado pelo SINITOX, referente a 2017 (último apresentado no site oficial da FIOCRUZ) ${ }^{8}$, sobre os casos registrados de intoxicação humana, resultaram em um total de 29.004, número inferior quando comparado ao ano anterior, que foi de 51.893 casos (2016). Nesses registros se nota a ausência da notificação da Região Sul do Brasil, e as demais, regiões não notificaram em sua totalidade. Em comparação aos anos anteriores, se nota uma redução no número de intoxicações, mas que o próprio sistema alerta ser em decorrência da diminuição da participação do Centros de Informação e Assistência Toxicológica (CIATs) nesses levantamentos, e não que o número de envenenamento vem reduzindo no pais.

O mesmo ocorre para casos de óbitos e letalidade de Intoxicações humanas advindos de agrotóxicos por uso agrícola e doméstico, que somam em todo o Brasil mais de 3 mil, com confirmação de óbito em 89 casos, mas que no ano anterior somavam mais de 5 mil casos, com aproximadamente 100 óbitos (SINITOX, 2017).

Nos casos registrados de Intoxicação Humana por Agente Tóxico e Faixa Etária podese perceber que os mais acometidos desde o levantamento de 2010 são os que se encontram nas idades entre 20 e 50 anos. Destaca-se nesse período um número expressivo no ano de 2010 de jovens entre 20 e 29 anos, intoxicados por produtos agrícolas. Outro alarmante ao analisarmos esses números, são as faixas etárias menores, que contempla crianças com menos de 1 ano de idade até adolescentes entre 15 e 19 anos, onde há presença de números acentuados, mantendose superiores a 100 intoxicações, entre intoxicações por produtos agrícolas e domésticos. Sobre os mesmos produtos, em relação ao sexo, 1308 casos são homens e 783 são mulheres

\footnotetext{
${ }^{8}$ Consulta ao site https://sinitox.icict.fiocruz.br/dados-nacionais realizada em junho de 2020.
} 
(SINITOX, 2017). Do total de casos registrados de intoxicação humana de 2016, 51.893 casos, 215 levaram a óbito, sendo 82 por agrotóxicos agrícolas, e grande maioria concentrada nas faixas etárias de 15 a 59 anos. Considerando nesses casos a subnotificação, o número total de notificações apresentados nessa discussão (652.721 totais e 29.137 por produto agrícola) pode, e deve ser ainda maior.

Outra possibilidade é que muitos desses casos sejam notificados pelo SINAN vinculado diretamente ao Ministério da Saúde, que visa realizar a notificação deste agravo (intoxicação por agrotóxicos) e de outros (BOCHNER, 2007).

Em 2007 foi lançado um manual que possuía como finalidade padronizar a utilização do SINAN, nas três esferas de governo. O sistema foi implantado, de forma gradual, a partir de 1993. No entanto, esta implantação foi realizada de forma heterogênea nas unidades federadas e municípios, não havendo uma coordenação e acompanhamento por parte dos gestores de saúde, nas três esferas de governo. Em 1998, o Centro Nacional de Epidemiologia (CENEPI) retoma este processo, desenvolvendo instrumentos, definindo fluxos e um novo software para o SINAN, além de definir estratégias para sua imediata implantação em todo o território nacional, através da Portaria Funasa/MS n. ${ }^{0} 073$ de 9/3/98 (BRASIL, 1998), sendo então o SINAN regulamentado.

Nesse manual fica claro a função de cada esfera, e no que compete aos municípios, entre outras atribuições, coletar e consolidar os dados notificantes, estabelecer fluxos e prazos, enviando-os a esfera estadual, que tende passar a próxima esfera.

Em última atualização disponível no SINAN em 2019, os casos de notificações demonstram expressivo a aumento em 2017 (Tabela 2). Ainda assim, é possível claramente verificar que os dados ainda não expressam a realidade. 
Tabela 3. Intoxicação exógena - Notificações registradas no SINAN Net - Brasil

\begin{tabular}{|c|c|}
\hline \multicolumn{2}{|c|}{$\begin{array}{c}\text { Agente Tóxico: Agrotóxico agrícola, Agrotóxico doméstico, Agrotóxico saúde pública } \\
\text { Período: } 2017\end{array}$} \\
\hline Ano $1^{\circ}$ Sintoma(s) & Notificações \\
\hline$<1975$ & 2 \\
\hline 1975 & 1 \\
\hline 1979 & 1 \\
\hline 1990 & 1 \\
\hline 1992 & 1 \\
\hline 1994 & 1 \\
\hline 1995 & 1 \\
\hline 2000 & 2 \\
\hline 2001 & 1 \\
\hline 2002 & 1 \\
\hline 2007 & 1 \\
\hline 2009 & 2 \\
\hline 2010 & 3 \\
\hline 2011 & 4 \\
\hline 2012 & 6 \\
\hline 2013 & 3 \\
\hline 2014 & 8 \\
\hline 2015 & 30 \\
\hline 2016 & 143 \\
\hline 2017 & 7200 \\
\hline Total & 7412 \\
\hline
\end{tabular}

Fonte: Ministério da Saúde/SVS - Sistema de Informação de Agravos de Notificação - SINAN Net. Acesso em junho de 2019.

Nota: Os dados apresentados nesse estudo pelo SINAN tiveram suas últimas atualizações em 2019, as quais ainda podem sofrer alterações.

$\mathrm{Na}$ análise de intoxicações por Agrotóxico Agrícola é possível verificar predomínio maior na Região Sudeste, seguida da Região Sul. É importante destacar que os baixos índices de intoxicação nas demais regiões, não significam menor exposição a riscos, ou maiores cuidados a saúde, mas expressam falhas no Sistema de notificação. 
Tabela 4 - Notificações registradas no SINAN net por Região do Brasil

Notificações por Região de notificação

Agente Tóxico: Agrotóxico agrícola, Agrotóxico doméstico, Agrotóxico saúde pública Período:2017

\begin{tabular}{cc}
\hline Região de notificação & Notificações \\
\hline 1. Região Norte & 553 \\
\hline 2. Região Nordeste & 1583 \\
\hline 3. Região Sudeste & 2618 \\
\hline 4. Região Sul & 1888 \\
\hline 5. Região Centro-Oeste & 770 \\
\hline Total & 7412 \\
\hline
\end{tabular}

Fonte: Ministério da Saúde/SVS - SINAN Net.

A subnotificação é um fator muito grave para uma real avaliação dos impactos do uso de agrotóxicos no país. Segundo a Organização Mundial da Saúde (OMS) cerca de três milhões de pessoas no mundo sofrem anualmente algum episódio de intoxicação decorrente da exposição a pesticidas, e os dados de incidência apresentados nos sistemas vigentes não condizem com a realidade, sugerindo que os números de intoxicações podem ser bem maiores (PIRES; CALDAS; RECENA, 2005).

No Brasil, 84,2 mil pessoas sofreram intoxicação após exposição a defensivos agrícolas entre 2007 e 2015, uma média de 25 intoxicações por dia, conforme dados do Relatório Nacional de Vigilância em Saúde de Populações Expostas a Agrotóxicos 2018, elaborado pelo MS (BRASIL, 2018). Para tais estimativas leva-se em conta o número de casos notificados no país, multiplicados por 50, fator de correção usado pelo Ministério da Saúde para dimensionar o número de casos não notificados. Sendo assim, a partir do levantamento do SINITOX, no Brasil, o número estimado corrigido de casos de intoxicações humanas totais seria de aproximadamente 33 milhões (dessas somente 652.721 notificadas no sistema) e de 1,5 milhões por agrotóxicos de uso agrícola (número de casos notificados: 29.137).

Lançado pelo MS em 2006, o documento Diretrizes para Atenção Integral à Saúde do Trabalhador de Complexidade Diferenciada esclarece que são consideradas expostas a agrotóxicos todas as pessoas que entram em contato com esses produtos em função de suas atividades laborativas, através do meio ambiente, da utilização doméstica ou acidental.

Dessa forma, as intoxicações ocorrem por duas vias: direta ou indireta. A primeira 
resulta da exposição ao produto decorrente do manuseio e aplicação. A segunda acontece pela contaminação do ambiente, através de resíduos presentes no ar, na água ou nos alimentos (NOBRE, 1996).

Segundo esse documento, os agrotóxicos podem causar quadros de intoxicação aguda e crônica, sendo essas alterações no estado de saúde de um indivíduo e/ou grupo de pessoas resultante da interação nociva de uma substância com o organismo vivo, e que pode se manifestar de forma leve, moderada ou grave: 
Quadro 1 - Classificação das Intoxicações por Agrotóxicos

\section{Tipos de intoxicação}

\begin{tabular}{|c|c|}
\hline Aguda & Crônica \\
\hline $\begin{array}{l}\text { Pode ocorrer de forma leve, moderada ou } \\
\text { grave, a depender da quantidade de veneno } \\
\text { absorvido, do tempo de absorção, } \\
\text { da toxicidade do produto e do tempo } \\
\text { decorrido entre a exposição e o } \\
\text { atendimento médico. }\end{array}$ & $\begin{array}{l}\text { Os efeitos danosos sobre a saúde humana, } \\
\text { incluindo a acumulação de danos } \\
\text { genéticos, surgem no decorrer de repetidas } \\
\text { exposições ao toxicante, que normalmente } \\
\text { ocorrem durante longos períodos de tempo. }\end{array}$ \\
\hline
\end{tabular}

Sinais e sintomas

Conjunto de sinais e sintomas, que se $\quad$ Nestas condições os quadros clínicos são apresenta de forma súbita, alguns minutos ou algumas horas após a exposição excessiva de um indivíduo ou de um grupo de pessoas a um toxicante, entre eles os agrotóxicos. Tal exposição geralmente é única e ocorre num período de até 24 horas, acarretando efeitos rápidos sobre a saúde. indefinidos, confusos e muitas vezes irreversíveis. Os diagnósticos são difíceis de serem estabelecidos e há uma maior dificuldade na associação causa/efeito, principalmente quando há exposição a múltiplos produtos, situação muito comum na agricultura brasileira.

\begin{tabular}{l|l|l}
\hline \multicolumn{3}{c}{ Caracterização dos quadros clínicos de intoxicação } \\
\hline Classificada em Leve, Moderada e Grave. & Manifesta-se através de inúmeras \\
Os sintomas comuns são: cefaleias, & patologias, que atingem vários órgãos e \\
irritação cutaneomucosa, dermatite de & sistemas, com destaque para os problemas \\
contato irritativa ou por hipersensibilidade, & imunológicos, hematológicos, hepáticos \\
náuseas vômitos, cólicas abdominais, & neurológicos, malformações congênitas e \\
tontura, & fraqueza & tumores. \\
generalizada,parestesia,dispneia, salivação & \\
e sudorese aumentadas. Também são sinais & \\
as arritmias cardíacas, insuficiência & \\
respiratória, edema agudo do pulmão, & \\
pneumonite química, $\quad$ convulsões, & \\
alterações da consistência, choque, coma, & \\
podendo evoluir para óbito. & \\
\hline Referências: (BRASIL, 1997; SILVA; NOVATO-SILVA; FARIA, 2005).
\end{tabular}


Porém, é preciso que a equipe de saúde e o médico em particular, fiquem atentos ao paciente, pois nem sempre, os limites entre um nível e outro se encontra bem definido. Ressaltese ainda, que dependendo do produto envolvido na intoxicação, da via de absorção, da quantidade de veneno absorvido e do tempo de absorção, o quadro clínico pode evoluir de um estágio para o outro (SILVA; NOVATO-SILVA; FARIA, 2005).

Essa classificação também auxilia no entendimento sobre as subnotificações registradas pelos sistemas de notificações. Não há dúvidas de que os casos de intoxicação por agrotóxicos registrados pelo sistema são em sua grande maioria decorrentes de exposição aguda a esses produtos. Nesse sentido, a importância dos efeitos crônicos à saúde das populações expostas aos agrotóxicos é mais um forte componente da subnotificação desse sistema, pois não é difícil inferir que o número de intoxicações crônicas por agrotóxicos é superior ao das intoxicações agudas.

Bochner (2007) também ressalta sobre a ausência de registros oficiais acerca desses efeitos crônicos, e sugere ser esse mais um fator que contribui para que a ação das empresas agroquímicas passe por despercebido.

Em 1996, a Organização Pan-Americana da Saúde juntamente com a OMS (OPAS/OMS) lançou um documento "Manual de Vigilância da Saúde de Populações Expostas a Agrotóxicos" no qual menciona as possíveis manifestações de intoxicações pelos agrotóxicos, com os efeitos agudos e crônicos, e especifica quais sintomas podem ser causados por determinado produto. Dentre as manifestações de intoxicações crônicas estão: efeitos neurotóxicos retardados, alterações cromossômicas, lesões hepáticas e renais, neuropatias periféricas, disfunções cardíacas, dermatites de contato, asma brônquica, Doença de Parkinson, teratogêneses, diversos tipos de câncer, fibrose pulmonar, hipersensibilidade, deixando em aberto a relação de outras consequências menos comuns ou menos estudadas (OPAS, 1996).

Quase dez anos após o lançamento deste documento, o MS lançou o "Protocolo de Atenção à Saúde dos Trabalhadores Expostos a Agrotóxicos" que confirmou algumas das patologias anteriormente citadas e acrescentou outras: neoplasias, como mieloma múltiplo e leucemias; anemia aplástica; transtornos mentais, como alterações cognitivas e episódios depressivos; doenças do sistema nervoso como distúrbios do movimento, polineuropatias e encefalopatia tóxica; oculares, como neurite óptica e distúrbios da visão e ainda auditivas, circulatórias, respiratórias, digestivas e dermatológicas (BRASIL, 2006).

Decorridos mais 10 anos, o MS em 2016 apresenta o "Relatório nacional de vigilância em Saúde de populações Expostas a Agrotóxicos”, onde apresenta dados e análises sobre uso de agrotóxicos, intoxicações e suas decorrências, como suicídios e homicídios, além da 
contaminação da água. Fala ainda sobre a política de vigilância das populações expostas, nos municípios prioritários e grandes regiões. Por meio deste relatório o MS confirma o uso ostensivo de agrotóxicos no Brasil e aponta um aumento desproporcional da comercialização em comparação com a área plantada, tais como o aumento ocorrido entre 2007 e 2013, no qual as vendas aumentaram 90,5\% no país, enquanto a área plantada aumentou apenas 19,5\%. Esses dados sugerem a ocorrência de uma intensificação na aplicação de agrotóxicos na produção e, com isso, um risco maior de exposição da população a partir do trabalho no campo e da contaminação do meio ambiente, da água e dos alimentos.

Ainda sobre o documento supracitado, há uma descrição de dados sobre a evolução dos casos de intoxicação por agrotóxicos no país, demonstrando que, no período de 2007 a 2014, São Paulo foi o estado com o maior número de casos notificados (12.562), seguido por Paraná (10.967 casos), Minas Gerais (10.625 casos) e Pernambuco (5.734 casos). O MS admite, porém, que há subnotificação expressiva das intoxicações por agrotóxicos, contribuindo para invisibilidade da magnitude do problema no país. Também é exposto acerca dos produtos agrotóxicos, tais como o glifosato, sendo o mais utilizado no país, o qual no ano passado, esse princípio ativo foi classificado como provavelmente cancerígeno para humanos pela Agência Internacional de Pesquisa em Câncer (IARC, na sigla em inglês), órgão vinculado à OMS.

Com base nesses estudos realizados pelos órgãos públicos e nas tabelas de ocorrências apresentadas nesse capítulo, como as do SINITOX e do SINAN, é possível observar que, no geral, essas intoxicações não são reflexo de uma relação simples, entre o produto e a pessoa exposta. Segundo a OPAS/OMS (BRASIL, 1996) vários fatores participam de sua determinação, dentre eles os fatores relativos às características químicas e toxicológicas do produto, fatores relativos ao indivíduo exposto, às condições de exposição ou condições gerais do trabalho, conforme mostra o Quadro 02 abaixo: 
Quadro 2 - Fatores determinantes de intoxicações

\begin{tabular}{|c|c|c|}
\hline Características do produto: & & $\begin{array}{l}\text { Características toxicológicas, forma de } \\
\text { Apresentação, estabilidade, solubilidade, presença } \\
\text { de contaminantes, presença de } \\
\text { solventes, etc. }\end{array}$ \\
\hline $\begin{array}{l}\text { Características } \\
\text { exposto: }\end{array}$ & indivíduo & $\begin{array}{l}\text { Idade, sexo, peso, estado nutricional, escolaridade, } \\
\text { conhecimento sobre os efeitos a medidas de } \\
\text { segurança, etc. }\end{array}$ \\
\hline Condições de exposição: & & $\begin{array}{l}\text { Condições gerais do trabalho, frequência, dose, } \\
\text { formas de exposição, etc. }\end{array}$ \\
\hline
\end{tabular}

Fonte: OPAS/OMS, 1996.

Atentos a isso, evidencia-se a importância do cuidado no manejo dos produtos químicos. Esse manuseio dos agrotóxicos, segundo Bulow e Foleto (2008) requer cuidados especiais que devem ser tomados a partir do momento em que esses produtos são adquiridos no mercado, no seu transporte, armazenamento, preparo, aplicação, limpeza das embalagens e equipamentos utilizados, a fim de minimizar os efeitos negativos de tais substâncias à saúde das pessoas e ao meio ambiente.

Esse cuidado está regulamentado pela Lei $n^{\circ} 7.082 / 89$, outrora citado nesse capítulo, que dispõem sobre o uso, inspeção e fiscalização dos agrotóxicos, entre outras providências.

Além disso, a compra dos produtos deve ser feita sob orientação técnica, não podem ser transportados agrotóxicos junto a outras mercadorias e animais, sendo necessário adotar procedimentos adequados para a armazenagem dos produtos (RIBEIRO et al.,1998).

Conforme a Associação Nacional de Defesa Vegetal (ANDEF, 1997), os agrotóxicos devem ser depositados em armazéns de alvenaria, com o piso impermeável para facilitar a limpeza e não permitir a infiltração. O local precisa ser arejado, cercado, telado, pintado, sinalizado e fechado com cadeado. Obedecendo as regras dos órgãos responsáveis pela localização das edificações, é necessário que sejam construídas longe da residência, das instalações para animais e das fontes de água (poços, rios, açudes, cisternas e cacimbas).

O que pode ser percebido, no entanto, é que a maior parte dos acidentes com agrotóxicos ocorre, justamente, durante o seu manuseio; no preparo da calda e na aplicação do produto no campo, que podem ser evitados com o uso de equipamentos de proteção adequados (BULOW; FOLETO, 2008). 
Nesse contexto, foram criados os Equipamentos de Proteção Individual (EPIs), definidos pela Norma Regulamentadora n 6 (NR-6) do Ministério do Trabalho, que considera todo dispositivo ou produto, de uso individual utilizado pelo trabalhador, destinado à proteção de riscos suscetíveis de ameaçar a segurança e a saúde no trabalho. Assim, seu principal objetivo é a diminuição da exposição durante as etapas que antecedem a aplicação, ou seja, o preparo da calda, a aplicação e as etapas após a aplicação de agrotóxico.

No meio rural, os EPIs mais comumente utilizados são: máscaras protetoras, óculos, luvas impermeáveis, chapéu impermeável de abas largas, botas impermeáveis, macacão com mangas compridas e avental impermeável. Normalmente, o uso desses EPIs é indicado via receituário agronômico e nos rótulos dos produtos, e devem possuir Certificado de Aprovação do Ministério do Trabalho.

Além disso, algumas especificidades devem ser observadas em relação ao manuseio dos EPI: os filtros das máscaras e respiradores são específicos para defensivos e têm data de validade; as luvas recomendadas devem ser resistentes aos solventes dos produtos; o trabalhador deve seguir as instruções de uso de respiradores; a lavagem deve ser feita usando luvas e separada das roupas da família; e devem ser mantidos em locais limpos, secos, seguros e longe de produtos químicos (CORDEIRO, 2003).

As embalagens de agrotóxicos utilizadas também representam riscos a saúde humana e ao ambiente, e por esse motivo devem ser destruídas.

A Lei $n^{\circ} 9.974$, de 6 de junho de 2000, estabelece claramente sobre a devolução das embalagens vazias de agrotóxicos, prevendo a operação de tríplice lavagem; a responsabilidade das empresas produtoras e comercializadoras de agrotóxicos, seus componentes e afins, assim como a destinação das embalagens vazias dos produtos por elas fabricados e comercializados, após a devolução pelos usuários; e responsabilidade administrativa, civil e penal para o produtor, o comerciante e o usuário. O não cumprimento das responsabilidades implica penalidades previstas na legislação específica e na lei de crimes ambientais, $n^{\circ} 9.605$, de 13 de fevereiro de 1998.

Outro fator importante é o contrabando de produtos, os quais, não há prescrição e nem local de coleta regulamentado, fazendo com que o produtor rural descarte de maneira inadequada as embalagens, queimando-as, enterrando, ou descartando em terrenos e matas, entre outros.

É possível verificar, por meio de estudos que, na prática, essas normas não são integralmente cumpridas. Em geral a principal queixa dos agricultores que manuseiam os produtos químicos recorre sobre a inadequação dos EPI's as condições de trabalho. São diversos 
os problemas que podem acarretar a inadequação desses, como por exemplo, as próprias características projetadas para conferir maior segurança podem estar introduzindo dificuldades operacionais em muitas situações de trabalho. Outro aspecto importante é a dificuldade da adequação dos EPIs às características antropométricas e ambientais de cada localidade (VEIGA et al., 2007).

Os resultados encontrados por Recena e colaboradores (2006) indicaram que o agricultor que não usa corretamente o EPI e/ou aplica o produto agrotóxico numa situação de risco reconhece sua vulnerabilidade, mas se sente resignado e impotente diante dela. Segundo os autores, os produtores deixam de usar o EPI com o pretexto de que é desconfortável, muito quente e dificulta a respiração, mesmo sabendo que seu uso visa proteger a saúde. Embora esses fatores sejam limitantes ao uso de EPI, observa-se que a grande maioria dos agricultores adquire o equipamento de proteção no momento da compra dos defensivos.

Para Schmidt e Godinho (2006), as justificativas para o não uso desses equipamentos foram manifestadas em três situações distintas: (I) desprezo pelos equipamentos devido à incerteza quanto à eficácia dos mesmos; (II) queixas de incômodos; e (III) atropelos das atividades do dia-a-dia. Soma-se a estas questões o fator econômico.

Para Nina (2002) a situação de analfabetismo ou a baixa instrução escolar, predominante entre os agricultores, torna as informações contidas nas etiquetas do produto difícil de entender, contribuindo para o escasso conhecimento sobre a periculosidade e toxicidade do produto.

Além disso, os EPIs podem se tornar uma fonte de contaminação, criando um risco à saúde humana. Segundo Veiga e coautores (2007), as falhas nos cuidados básicos de conservação e nos procedimentos de despir/vestir os colocam como prováveis fontes de contaminação do trabalhador.

No Brasil, o problema de inadequação dos EPIs às condições ergonômicas e ambientais também não é estranho. Na agricultura brasileira, especialmente em pequenas comunidades rurais, é comum deparar-se com trabalhadores rurais sem os EPIs obrigatórios durante a manipulação e a aplicação de agrotóxicos. Uma das principais razões para não se utilizar os equipamentos reside no fato de que muitos dos EPIs utilizados na agricultura, devido a sua inadequação, podem provocar desconforto térmico, tornando-os bastante incômodos para uso, podendo levar, em casos extremos, ao estresse térmico do trabalhador rural (COUTINHO et al., 1994).

Apesar da utilização de EPIs resultar em um problema para a saúde dos trabalhadores, não foi identificado laboratório independente no Brasil que esteja analisando a adequação das 
tecnologias de EPIs. Os laboratórios de EPIs existentes no Brasil, credenciados pelo Ministério do Trabalho e Emprego (MTE), limitam-se a realizar testes padrões que visam principalmente aprovar (obtenção do certificado de aprovação) a comercialização e/ou produção de certos EPIs no Brasil (VEIGA et al., 2007).

Veiga e colaboradores (2007) ainda afirmou que a maioria dos EPIs comercializados no Brasil não passa por qualquer teste devido à falta de laboratórios capacitados/credenciados para realizar as análises necessárias. Não existem sequer padrões para conforto térmico ou para permeabilidade. Com isso, muitos EPIs são comercializados no Brasil apenas com a assinatura de um termo de responsabilidade.

A falta de informação se constitui em outro problema relacionado ao uso dos EPI. Para Jacobson e colaboradores (2009), os fatores responsáveis pela contaminação por agrotóxicos se devem, em grande parte, pela inexistência de aconselhamento técnico adequado dos órgãos responsáveis pela indicação agronômica, além da falta de fiscalização e aplicabilidade das leis, da base educacional e das campanhas de esclarecimento em relação aos riscos da exposição aos agrotóxicos. Por esse motivo, os autores ressaltaram a necessidade de campanhas direcionadas para a educação ambiental da população de estudo, com ênfase no risco de intoxicação devido ao uso inadequado dos agrotóxicos e da proximidade das moradias das áreas de cultivo.

Em estudos de outras áreas, não vinculadas à agricultura, a discussão acerca do uso e não uso dos EPI's também é constante. Neves e colaboradores (2011) realizou um estudo acerca da segurança de trabalhadores da enfermagem e fatores determinantes para adesão dos equipamentos de proteção individual, e constatou que as razões, atitudes e crenças relativas ao cumprimento do uso dos EPI's demonstra que os indivíduos expostos conhecem os riscos a que estão expostos no ambiente de trabalho, mas que esse conhecimento nem sempre é suficiente para evitar a exposição. As barreiras apontadas para baixa adesão ao uso de equipamentos de proteção individual estão associados a organização, gestão e equipamentos relacionados, expressa como: estrutura física inadequada; disponibilidade e acesso aos equipamentos de proteção; ausência de rotina; sobrecarga de trabalho; stress; improvisação e exaustão nas relações de trabalho.

Apesar das inúmeras barreiras que dificultam o cumprimento da utilização dos equipamentos de proteção, nesse trabalho foi possível perceber que os profissionais reconhecem os seus benefícios e não se eximem da responsabilidade pessoal para o uso de equipamentos de proteção individual. Trata-se de um comportamento individual e pessoal, mas fortemente determinada pelas crenças de saúde (NEVES et al., 2011).

Essa tese confirmou-se em estudo semelhante que analisou a utilização de EPIs pelos 
trabalhadores de enfermagem nas unidades de terapia intensiva de um hospital de emergência, e revelou que os técnicos e auxiliares de enfermagem têm consciência da importância do uso dos equipamentos, porém não os utilizam com a devida frequência na prática de seu cotidiano laboral, devido a problemas de ordem comportamental e de logística (SOUZA et al., 2011).

Em um recente estudo realizado com mototaxistas, com o objetivo de analisar as práticas e percepções desses indivíduos a respeito do uso dos EPIs, concluiu que os mototaxistas têm algum conhecimento acerca dos equipamentos de proteção ocupacional e, inclusive, atribuem importância ao devido uso desses instrumentos, entretanto, nem sempre fazem o uso adequado deles (TEIXEIRA et al., 2014).

Além dos argumentos sobre desconforto e má adaptação em relação aos EPI's, também é possível verificar atualmente, que devido a melhoria dos maquinários agrícolas, como cabines climatizadas, há a construção de uma falsa ideia do produtor, o qual acredita que estando dentro da cabine, não é exposto ao risco de intoxicação pelo produto.

\subsubsection{Exposição a agrotóxicos: impactos na saúde}

A partir do exposto no decorrer deste Capítulo 1, é possível verificar que com o aumento do uso de agrotóxicos no País, o risco de exposição da população a partir do trabalho e da contaminação do meio ambiente, da água e dos alimentos sofreram significativo aumento. Também, devido a sua toxicidade intrínseca, os agrotóxicos produzem efeitos deletérios à saúde humana que variam de acordo com o princípio ativo, a dose absorvida, a forma de exposição e as características individuais da pessoa exposta. As consequências descritas na literatura compreendem alergias; distúrbios gastrintestinais, respiratórios, endócrinos, reprodutivos e neurológicos; neoplasias; mortes acidentais; e suicídios (OPAS/OMS, 1996). Além disso, os grupos mais suscetíveis a esses efeitos são trabalhadores, crianças, gestantes, lactentes, idosos e pessoas com problemas de saúde.

Embora a pesquisa do impacto dos agrotóxicos sobre a saúde humana tenha crescido, ainda é insuficiente para reconhecer a extensão da carga química de exposição ocupacional que cause danos à saúde, principalmente sobre os efeitos crônicos. A desinformação e o despreparo dos sistemas de saúde locais podem fazer com que os casos passem despercebidos, gerando subnotificação (MOREIRA et al., 2002). Sabendo-se, no entanto, que agrotóxicos são substâncias cada vez mais utilizadas na agricultura e oferecem perigo para a fauna e flora em geral, incluindo seres humanos, pois podem ser absorvidos via dérmica, inspirados pelos pulmões ou ingeridos em produtos contaminados, que seus efeitos tóxicos dependem de suas 
características químicas, da quantidade absorvida ou ingerida, do tempo de exposição e das condições gerais de saúde da pessoa contaminada (CASTRO; CONFALONIERI, 2005; BRASIL, 2006; PAGNANTI; MACHADO; CABRAL, 2007; DELLAMATRICE; MONTEIRO, 2014).

Sobre os efeitos crônicos na saúde humana, uma revisão de literatura realizada nos Estados Unidos e Canadá em 2012 demonstrou que a exposição aumenta o risco de desenvolvimento de cânceres, principalmente de pulmão, pâncreas, colón e reto, cancros linfohematopoiéticos, leucemia, mama, bexiga e próstata, melanomas, além de canceres cerebrais. Também, apresentou maior risco de câncer oral e infantil, de crianças expostas aos agrotóxicos (WEICHENTHAL; MOASE; CHAN, 2012).

À nível nacional, outra revisão sobre a presença de agrotóxicos na atmosfera e o risco a saúde humana, apresentou estudos epidemiológicos que associaram o ar contaminado por agrotóxicos e desfechos específicos como, linfoma não Hodgkin (LNH) e Esclerose Lateral Amiotrófica (ELA). Os achados desta revisão refletiram uma carência de estudos abordando o tema pela saúde pública, e reiteraram que a contaminação atmosférica por agrotóxicos oferece riscos potenciais à saúde humana, e que tais estudos devem ser ampliados na ciência brasileira, a fim de aprofundar o conhecimento sobre o assunto e respaldar a capacidade de atuação da Vigilância em Saúde Ambiental (SOUZA, 2017).

Entretanto, em outro estudo que investigou a percepção de trabalhadores rurais portadores de neoplasia sobre as implicações do uso de agrotóxicos, verificou que os agricultores têm noção dos riscos do uso de agrotóxicos para sua saúde, para o meio ambiente e para os consumidores, no entanto, os classificam como necessários a fim de manter a produtividade na agricultura (DALCOL et al., 2016).

Em uma análise sobre os impactos do uso de agrotóxicos em Minas Gerais constatou possibilidade risco ao aparelho respiratório dos trabalhadores que podem ser desde uma gripe alérgica, até problemas crônicos, como a asma, a bronquite e a pneumonia (RIBEIRO, 2014).

Diversos estudos também têm mostrado o impacto na qualidade de vida, relacionada a saúde auditiva ou de maneira geral, demonstrando que o uso e manuseio de agrotóxicos interferem na saúde física, psicológica e nas relações sociais (OLIVEIRA; VARGAS; SENA, 2012; SIQUEIRA et al., 2013; 2012).

Efeitos no sistema auditivo também são comprovados na literatura, principalmente no que se refere ao poder ototóxicos e neutóxico de alguns defensivos agrícolas sobre o sistema auditivo periférico e para o central, que somados ao ruído causado pelo maquinário agrícola, potencializam os efeitos, causando alterações na saúde em geral e na auditiva (HOSHINO et 
al., 2009; KÓS et al., 2013; 2014). Além do sistema auditivo, também já foi comprovada significativa relação dos agrotóxicos com alterações no sistema vestíbulococlear (KORBES et al., 2010a; 2010b)

É possível constatar também que agricultores tendem a subestimar os dados sobre exposição ocupacional aos agrotóxicos e sobre intoxicações, e por outro lado, tende a superestimar as informações sobre o uso de medidas de proteção (FARIA et al., 2004).

Acerca disso, estudos apontam que ainda há carência de conhecimento sobre o uso correto destes produtos, ou até mesmo, aplicação na prática. Em um estudo nacional recente que objetivou avaliar o perfil dos trabalhadores rurais de um município no Estado do Piauí, bem como, suas práticas e atitudes quanto à utilização de agrotóxicos, verificou que os agricultores, em sua maioria, usavam agrotóxicos inadequadamente, tinham baixa escolaridade e conheciam sobre os riscos individuais e coletivos aos quais estavam expostos, mas não usavam EPIs (SANTANA et al., 2016). O mesmo ocorreu em outro estudo realizado no Estado do Rio Grande do Norte, que pretendeu realizar um levantamento acerca do uso de agroquímicos pelos produtores de banana a fim de investigar sobre o manuseio desses produtos, e os resultados do inquérito constatou que os trabalhadores tinham certo nível de conscientização com relação ao receituário agronômico, percebiam que os produtos eram perigosos, liam o rótulo das embalagens e reconheciam a necessidade de utilização dos EPIs, entretanto, quanto as práticas, demonstraram deficiência quanto ao respeito ao período de carência do produto, utilização de todos os equipamentos, a ordem de retirá-los e o destino das embalagens vazias notou-se deficiência nas práticas corretas (ROCHA; OLIVEIRA, 2016).

Outro trabalho com objetivos semelhantes ao supracitado, demonstrou que a maioria dos agricultores não leem sempre o receituário agronômico e não compreende totalmente as informações contidas na bula, as tarjas e os desenhos presentes nos rótulos dos agrotóxicos, e faz o uso parcial dos EPIs (BOHNER et al., 2013).

No Sul do país, em Rio Grande do Sul, a investigação pretendeu compreender como os agricultores identificam os impactos positivos e negativos do trabalho agrícola familiar no ambiente e conservam a saúde ambiental. Constaram, entre os impactos positivos, a geração de alimentos com responsabilidade, a valorização do trabalho, a correta, mínima ou nula inserção dos agrotóxicos, porém, como aspectos negativos, o uso excessivo e incorreto dos agrotóxicos e a ausência de conhecimentos para agricultar (BORGES et al., 2016). Ainda no mesmo estado brasileiro, outro estudo evidenciou-se que os agricultores conhecem os riscos para sua saúde advindo do uso de agrotóxicos, bem como, os riscos sobre a não utilização dos equipamentos 
de proteção individual, porém não adotam medidas preventivas, carecendo de ações direcionadas a saúde destes trabalhadores (VIERO et al., 2016).

Os trabalhos cima, apesar de apresentados resumidamente, denotam a carência ou pouca efetividade das ações de políticas públicas destinadas a essa população exposta a riscos. Não obstante, por serem produtos tóxicos, os agrotóxicos podem ter efeitos deletérios sobre a fitossanidade das lavouras, sobre a saúde humana, bem como sobre o meio ambiente. Então, há a necessidade de instituição de políticas públicas de regulamentação desses produtos, que legislam desde as etapas de pesquisa e desenvolvimento de novos produtos até o descarte final das embalagens condicionando, assim, as possibilidades de atuação estratégica das empresas do ramo dos agrotóxicos.

A iniciar pela significativa subnotificação de casos de intoxicação. Segundo a Portaria MS $n^{\circ} 1.271$, de 6 de junho de 2014, a intoxicação por agrotóxicos faz parte da Lista de Notificação Compulsória (LNC) do SUS e deve ser notificada semanalmente por meio da ficha de 15 intoxicações exógenas do SINAN por médicos, outros profissionais de saúde ou responsáveis pelos serviços públicos e privados de saúde que prestam assistência ao paciente; pelos responsáveis por estabelecimentos públicos ou privados educacionais, de cuidado coletivo, além de serviços de hemoterapia, unidades laboratoriais e instituições de pesquisa.

Os índices do SINAN demonstram aumento nas notificações no decorrer dos últimos 20 anos, entretanto, para garantir a identificação e notificação dos casos, bem como as estratégias de prevenção e de assistência, é imprescindível a organização e o fortalecimento das ações de Vigilância em Saúde Ambiental no âmbito dos estados e dos municípios.

Também se aponta para a necessidade de melhoria dos registros das declarações de óbito, em especial da ocupação e da relação dos diagnósticos com o trabalho, fundamentais para o controle e prevenção, a partir de analise realizada entre 2000 a 2009, no qual foram encontrados registros de 2.052 óbitos por intoxicação por agrotóxicos no Brasil, dos quais $36,2 \%(n=743)$ não continham dados sobre a ocupação, e excluídos os casos de suicídios (SANTANA; MOURA; NOGUEIRA, 2013).

Ao encontro disso, retoma-se a discussão da importância de produzir e difundir protocolos diagnósticos e terapêuticos, qualificar profissionais e aprimorar os mecanismos e fluxos de registro e análise das informações. A exposição humana a agrotóxicos representa, portanto, um problema de saúde pública. Em face disso, a Vigilância em Saúde de Populações Expostas a Agrotóxicos (VSPEA) busca efetivar ações integradas de prevenção, promoção, vigilância e assistência à saúde de populações expostas ou potencialmente expostas a esses produtos. 
Em 2009, o MS lançou o documento "Plano Integrado de Ações de Vigilância em Saúde de Populações Expostas a Agrotóxicos", como parte de uma proposta que busca transformar de forma sistêmica a própria estrutura dos programas de Saúde, e tem como principal objetivo priorizar a Promoção, a Atenção e a Vigilância em Saúde (BRASIL, 2009a).

Os principais objetivos que amparam o plano é "estabelecer ações de vigilância de riscos e agravos, medidas preventivas e de controle do uso de agrotóxicos, e contribuir para a construção e efetivação de um sistema de vigilância integrado". Para que isso seja alcançado o plano conta com esforços do Governo Federal para o aprimoramento de políticas públicas integradas e às estratégias do desenvolvimento sustentável.

Para elaborar e acompanhar a implantação do Plano Integrado do MS foi instituído no âmbito do MS um Grupo de Trabalho (GT), formado por representantes de órgãos e entidades do MS, que se responsabilizam por desenvolver as atividades propostas. Esse GT tem a responsabilidade de conceber e implementar as estratégias de atuação que competem ao nível federal. No caso dos estados e municípios serão elaborados planos e programações seguindo as orientações das diretrizes operacionais do Pacto pela Saúde e as diretrizes operacionais dos Pactos pela Vida e de Gestão (MOISÉS et al., 2011).

Seu cronograma compõe-se de ações organizadas em três fases, que serão realizadas em quatro anos e iniciadas em 2009: I - harmonização e elaboração de instrumentos; II Implantação no SUS e III - Consolidação e manutenção nas três esferas.

A partir das discussões do grupo de trabalho foi possível a identificação das interfaces de atuação entre as áreas envolvidas, permitindo assim a definição das ações e atividade agrupadas em quatro eixos:

1. Atenção integral em saúde das populações expostas a agrotóxicos;

2. Promoção à Saúde - referenciada devido à intersetorialidade de ações ocorrerem na localidade e nos ambientes aonde vivem as pessoas;

3. Agenda integrada de estudo e pesquisa;

4. Participação e controle social.

Em cada um dos eixos são apontadas suas diretrizes, ações e atividades prioritárias e estas contemplam a explicitação da ação, das atividades, das estratégias, dos prazos para início e término e o responsável no MS e dos órgãos e/ou entidade envolvidas (BRASIL, 2009a, MOISÉS et al., 2011).

As ações e desdobramentos decorrentes deste Plano propõem a organização do atendimento integral das demandas de saúde das populações expostas a agrotóxicos, no seu território, que serão realizados conforme estabelecido para os três níveis de gestão do SUS. 
Em suma, o Plano Integrado do MS sugere a realização de experiências piloto em parceria com estados e municípios e instituições acadêmicas para garantir sua consolidação e enfrentar os desafios da vigilância das populações expostas a agrotóxicos.

Quanto aos agrotóxicos, conclui-se que o controle dos problemas relacionados ao uso indiscriminado poderá ser alcançado com adoção de práticas alternativas ou quando estritamente necessário, pelo uso seguro e cuidadoso dessas substâncias (MOISÉS et al., 2011).

Para tal, os mesmos autores também consideram que o governo e a sociedade organizada devem estar unidos dentro de um objetivo maior que o lucro, a garantia da qualidade de vida para todos, trabalhadores e população consumidora. Confirma-se a necessidade de se estruturar um Sistema de Vigilância em Saúde de caráter nacional e integrado, relacionado aos agrotóxicos, reduzindo subnotificações, e amparando integralmente a população, principalmente no sentido de promoção e prevenção. Deve-se considerar, ainda, que a construção e efetivação do Plano permitirá ao MS e ao SUS, efetivos monitoramento e controle de situações de riscos à saúde humana relacionadas aos agrotóxicos.

Outras iniciativas também estão sendo tomadas pelo governo brasileiro representando avanços na incorporação das questões ambientais para atuação do setor de vigilância em saúde. O Programa de Vigilância em Saúde Ambiental relacionado às Substâncias Químicas (VIGIQUIM), que se encontra em implantação pelo MS, vem ao encontro dessa preocupação mundial, também explanada nesse trabalho, acerca dos potenciais riscos oferecidos pelas substâncias químicas para a saúde humana. Esse programa nacional é também regido pelos princípios básicos do SUS, e alinha-se com a necessidade do estabelecimento de esforço integrado entre os vários níveis de governo, o setor produtivo, representações da sociedade civil e demais partes interessadas na busca de um modelo de desenvolvimento que tenha o seu foco principal centrado na sustentabilidade das atividades humanas (BRASIL, 2009b).

Também se observa, em confronto com a crescente liberação de produtos agrotóxicos em nosso país, o Projeto de Lei 6670/16 na Câmara dos Deputados, da Comissão de Legislação Participativa, que institui a Política Nacional de Redução de Agrotóxicos. O texto foi apresentado a partir de sugestão da ABRASCO, e tem como objetivo implementar ações que contribuam para a redução progressiva do uso de agrotóxicos na produção agrícola, pecuária, extrativista e nas práticas de manejo dos recursos naturais. Além disso, ampliar a oferta de insumos de origens biológicas e naturais, contribuindo para a promoção da saúde e sustentabilidade ambiental, com a produção de alimentos saudáveis. No entanto, desde 2016 até o momento, segue aguardando instalação de comissão temporária e parecer do relator (BRASIL, 2018c). 
Outro documento que merece destaque nacional é o Dossiê Abrasco sobre agrotóxicos, que após de causar grande impacto em 2012, ganhou nova edição em 2015. A atualização dedica-se a apresentar fatos marcantes, estudos e decisões políticas, com informações que envolvem os agrotóxicos, as lutas pela redução dessas substâncias e pela superação do modelo de agricultura químico-dependente do agronegócio. O livro apresenta, por meio de estudos e fatos comprovados significativamente, tanto nacionais quanto internacionais, os efeitos nocivos à saúde e ao ambiente que a grave situação de uso indiscriminado de agrotóxicos no Brasil não é revertida (CARNEIRO et al., 2015).

Nesse Dossiê é possível encontrar evidencias científicas sobre os riscos na ingestão de alimentos com agrotóxicos, os resíduos encontrados nos alimentos e os agravos a saúde, além da contaminação de agua de consumo humano e da chuva, inclusive sobre resíduos no leite materno. Também é apresentado os desafios para as políticas públicas de controle e regulação de agrotóxicos e promoção de processos produtivos saudáveis, dentre muitas outras informações importantes no que se refere aos agrotóxicos e seus efeitos deletérios (CARNEIRO et al., 2015).

Alguns estados brasileiros também elaboraram políticas próprias, baseadas nos índices encontrados. No Paraná, destaque em consumo de agrotóxicos e berço de diversas pesquisas que comprovam seus efeitos nocivos no ambiente e na saúde humana, apresenta seu próprio plano, denominado "Política Estadual de Atenção Integral à Saúde do Trabalhador do Paraná". Publicada em 2011, as políticas públicas no campo da saúde do trabalhador, incluídas no plano, constituem:

\footnotetext{
ações implementadas pelo Estado do Paraná, visando a garantir que o trabalho, base da organização social e direito humano fundamental, seja realizado em condições que contribuam para a melhoria da qualidade de vida, da realização pessoal e social dos trabalhadores, sem prejuízo para sua saúde e integridade física e mental. Envolvem aspectos gerais, como a garantia do trabalho, a natureza e as relações de trabalho, a distribuição de renda, as questões diretamente relacionadas as condições e ambientes de trabalho, tendo em vista a promoção, proteção, recuperação da saúde e a reabilitação profissional (PARANÁ, 2011, pg. 13).
}

Esse documento, baseado nos princípios norteadores da Política Nacional de Saúde do Trabalhador - PNST se propõem a assumir os fundamentos que norteiam esse assunto regido pelo SUS, ressaltando a assistência à saúde dos Trabalhadores, que apesar de todos os esforços direcionados nos últimos anos, ainda é deficiente quanto a organização e hierarquização das ações. Isso reafirma a necessidade de uma rede de atenção básica amplamente preparada para 
o atendimento do trabalhador, bem como maior conhecimento da relação queixa- patologia (PARANÁ, 2011).

Em 2017 foi lançado o Plano de Vigilância e Atenção à Saúde de Populações Expostas a Agrotóxicos do Estado do Paraná, com vigência de 2017 a 2019, que visa o diagnóstico situacional da população exposta do estado, e que tem como objetivo principal executar as Ações Estratégicas de Vigilância e Atenção nos 399 municípios do Estado, visando prevenir as intoxicações agudas e crônicas e minimizar os efeitos danosos à saúde decorrentes da exposição aos agrotóxicos de uso agrícola e de uso urbano no estado do Paraná.

Para se atingir tal objetivo, fazem parte da estratégia implantar os Grupos de Trabalho (GT) Agrotóxicos Regionais para atuar sobre a problemática dos agrotóxicos na Região, além de implantar ações de cuidado à saúde da população exposta a agrotóxicos nos três níveis de atenção; realizar ações de vigilância em saúde dos fatores ambientais, ocupacionais, produtivos e do comércio, no campo de atuação da saúde e intervir nos fatores determinantes e condicionantes do risco à saúde na exposição de agrotóxicos, em ações intra-setoriais e intersetoriais com as diversas instituições que atuam na questão dos agrotóxicos (PARANÁ, 2018) .

A exemplo disso, outros estados, embora não apresentem um plano como o Paraná, também apresentam projetos de Lei, com a finalidade de redução de agrotóxicos, como a PERAGRO (Lei N²64/2017) do Rio Grande do Sul, as audiências públicas realizadas em São Paulo, que visam promover a agroecologia (Lei n²36/2017)

Com abrangência nacional e ganhando cada vez mais reconhecimento político, os resultados do Programa de Análise de Resíduos de Agrotóxicos em Alimentos (PARA) elabora em 2016 pela ANVISA, reforçam o que já vem sendo sinalizado pela Vigilância em Saúde Ambiental, de que a população brasileira em geral, não somente os trabalhadores rurais, está exposta a agrotóxicos. O último relatório complementar referente ao ano de 2012, publicado em 2014, analisou 1.397 amostras de alimentos coletadas no mercado varejista (supermercados e sacolões), sendo 25\% (347) consideradas insatisfatórias por apresentarem resíduos de produtos não autorizados ou autorizados, mas em concentrações acima do limite máximo permitido. Todas as unidades da Federação apresentaram amostras com algum percentual de inconformidade (ANVISA, 2016). O Programa vem contribuindo para chamar a atenção da necessidade de maior controle de qualidade dos alimentos por meio de ações que promovam a rastreabilidade das amostras, autuação de fornecedores irregulares e adoção de medidas educativas para os produtores agrícolas. 
Além dos alimentos, outro importante foco de exposição aos agrotóxicos é a água para consumo humano. Nesse sentido e, considerando as respectivas competências e responsabilidades atribuídas aos responsáveis pelos sistemas ou soluções alternativas coletivas de abastecimento de água (Controle) e ao setor Saúde (Vigilância), o Programa Nacional de Vigilância da Qualidade da Água para Consumo Humano (VIGIAGUA) executa o monitoramento dos parâmetros de agrotóxicos, com vistas a avaliar a presença de tais substâncias químicas nos municípios mais susceptíveis a essa contaminação, com o intuito de identificar os fatores de riscos e definir as ações preventivas e corretivas relacionadas à vigilância da qualidade da água para consumo humano no Brasil (BRASIL, 2016a).

Sobre o apresentado nesse capítulo, e considerando a exposição humana a agrotóxicos como importante problema de saúde pública, é possível verificar que o MS e do Meio Ambiente reconhecem a importância de gerir as pequenas unidades de saúde, a fim de monitorar melhor os casos, e traçar alternativas de cuidado seguras. No entanto, ainda há um longo caminho a ser percorrido para garantir a qualificação e a continuidade dessas ações. Além disso, a redução dos riscos e agravos à saúde relacionados aos agrotóxicos depende da atuação simultânea de diversos atores. 


\subsection{A GESTAÇÃO E OS IMPACTOS DECORRENTES DOS AGROTÓXICOS}

Nesse capítulo será contextualizado o processo de gestação humana, e os efeitos que possíveis intercorrências, principalmente advindos de intoxicações por produtos agrotóxicos podem acarretar a saúde do feto e da mãe. Por meio de uma revisão histórica, são apresentados relatos de estudos nacionais e internacionais que apresentam casos confirmados de desfechos indesejáveis na gestação. Por fim, discute-se como a saúde da gestante e do neonato é abordada pelas políticas públicas de atenção a população exposta a agrotóxicos.

\subsubsection{O período gestacional}

O período gestacional é marcado por diversas mudanças físicas e hormonais vividas pela mulher, a partir da concepção. Essa série de mudanças naturais são necessárias para que ocorra a adaptação do organismo da futura mãe em razão das necessidades metabólicas que a gravidez impõe ao corpo feminino, para dar conta de suprir as necessidades do crescimento e desenvolvimento do feto (GUNTHER, 1980).

Nesse período, o sistema endócrino inicia a produção de hormônios, que anteriormente não produzia, ou produzia em pequenas quantidades. São os hormônios da Retaxina, Progesterona, Estrogênio entre outros, que provocam alterações físicas a fim de preparar o corpo para a formação do feto, e dentre as principais mudanças que ocorrem, destacam-se o tamanho do útero, a cintura pélvica, o tamanho das mamas e a produção do leite materno, além de alterações de fluxo sanguíneo, elevação da pressão arterial e aceleramento dos batimentos cardíacos (MELEN, 1997; GUYTON; HALL, 2002).

Estas modificações fisiológicas geram a necessidade aumentada de nutrientes essenciais, como proteínas, carboidratos e os lipídios, que servem para manter a plena nutrição materna, uma vez que a única fonte de nutrientes do feto é constituída pelas reservas nutricionais da mãe. Nesta fase os cuidados com a gestação no sentido de evitar intercorrências perinatais, e as pós-natais devem ser intensificados, a fim de promover a plena saúde maternoinfantil (MELEN, 1997; GUYTON; HALL, 2002).

Os dados obtidos sobre o período perinatal e neonatal são elementos importantes para a avaliação do recém-nascido logo após o nascimento, uma vez que fornecem informações sobre o tipo de terminação do parto, informações sobre adaptabilidade e as condições vitais do recémnato no primeiro e no quinto minuto após o nascimento (Índice de Apgar), principais dados antropométricos do recém-nato (peso, comprimento e perímetros cefálico e torácico), 
informações sobre a duração da gravidez, identificando o recém-nato como pré-termo, a termo ou pós-termo (CHRISMAN, 2008).

A existência de quaisquer intercorrências pode gerar desfechos indesejáveis com diferentes comprometimentos ao feto, como baixo peso ao nascer, prematuridade e malformações congênitas, que são considerados fatores de risco para a mortalidade infantil (VICTORA; BARROS, 2001; COCKEY, 2005).

Os comprometimentos ao feto podem ser gerados por fatores de origem genética e/ou ambiental, tais como, desnutrição, stress, fumo, uso de drogas ilícitas e exposição a substâncias químicas e ocorrem tanto durante o período embrionário quanto fetal e são conhecidos como defeitos malformações ou anomalias congênitas (BRENT; BECKMAN, 1990; CARLSON, 1996; MISRA; NGUYEN, 1999; ASHDOWN-LAMBERT, 2005; SILBERGELD; PATRICK, 2005).

$\mathrm{Na}$ maioria das ocorrências as malformações genéticas ocorrem nos três primeiros meses de gestação e podem ser estruturais, funcionais, metabólicas, comportamentais ou hereditários, e nem sempre podem ser vistas ao longo da gestação e/ou no nascimento (MOORE; PERSAUD, 1994; FACCINI, 2002; CAVIERES, 2004). ${ }^{7}$

A definição para o termo Malformação Congênita (MC), segundo a OPAS, compreende qualquer defeito na constituição de algum órgão ou conjunto de órgãos que determine uma anomalia morfológica estrutural ou funcional, presente ao nascimento ou não, causado por fatores genéticos, ambientais ou mistos (OPAS, 1984). Podem ser classificadas como isoladas ou associadas, físicas ou mentais, simples ou múltiplas e de maior ou menor importância clínica (GARNE et al., 2011)

A OMS alerta que as $\mathrm{MC}^{9}$ são a maior causa de morbidade e mortalidade infantil hoje no mundo, atingindo 5\% de todos os nascidos vivos globalmente, sendo responsáveis por um grande número de mortes infantis em vários locais no mundo (ROSANO et al., 2000).

No Brasil o impacto dos defeitos congênitos vem aumentando progressivamente, tendo passado da quinta para a segunda causa dos óbitos em menores de um ano entre 1980 e 2000, apontando para a necessidade de estratégias específicas na política de saúde. Além disso, aqueles que sobrevivem têm a necessidade de cuidados especiais e hospitalares durante toda a

\footnotetext{
${ }^{9}$ Em relação as Malformações Congênitas (MC), muitas são as causas. Estudos apontam que de 40 a $65 \%$ dos defeitos de formação são de origem desconhecida; 20 a $26 \%$ são atribuídas a causas hereditárias e a anormalidades cromossomiais e 5 a $10 \%$ a doenças maternas, como diabetes e infecções ou ao uso de drogas ou contato materno com substâncias químicas ou agentes físicos - os chamados fatores ambientais (Tagliabue, et al, 2007; Brent \& Beckman, 1990; Faccini, et al,2002).
} 
vida, impactando a economia do país ${ }^{10}$ (WHO, 2002). ${ }^{8}$

As exposições químicas, físicas ou biológicas e suas possíveis consequências à saúde da mãe e os decorrentes efeitos deletérios ao feto durante o período gestacional só se tornaram preocupação aos pesquisadores e profissionais da saúde a partir do século XX (MOORE; PERSAUD, 1994; FACCINI et al., 2002).

\subsubsection{Efeitos teratogênicos dos agrotóxicos}

Atualmente numerosos estudos se atêm a investigar e avaliar a relação entre a exposição ocupacional materna e os resultados adversos na reprodução e gestação, inclusive associando ao aumento de ocorrências dos defeitos congênitos. Dentre os fatores de risco para a saúde da gestante, destacam-se os agrotóxicos, cujos malefícios já foram evidenciados pelas pesquisas no que concerne à saúde dos trabalhadores e para o meio ambiente. Embora ainda sejam recentes as investigações sobre essa relação em seres humanos, estudos experimentais em ratos e camundongos têm evidenciado uma série de alterações no desenvolvimento intrauterino, cujos danos são observados somente a posteriori. Embora os estudos em seres humanos ainda estejam em andamento, ao qual essa tese se inclui, já são observados riscos de alterações nos recémnascidos, filhos de mães que estiveram expostas aos agrotóxicos antes e durante a gestação (CLEMENTI et al., 2007).

O esquema a seguir (Figura 3), de autoria de Needham (2005) e traduzido para o português por Chrisman (2008), faz uma tentativa de representar, de forma ilustrada, como se dá a transferência dos agrotóxicos da mãe para o bebê. $O$ esquema elucida como a exposição ocupacional e/ou ambiental da mãe durante a gravidez ou mesmo em um período anterior a gravidez pode afetar ao feto, como visualizado na imagem.

\footnotetext{
${ }^{10} \mathrm{Na}$ América Latina, os defeitos congênitos respondem por um quarto das internações hospitalares pediátricas e estão entre a terceira e a quarta causa de óbito no primeiro ano de vida ${ }^{5}$. No Brasil, com a redução dos óbitos por causas infecto-contagiosas, consideradas componentes pós- neonatais, as mortes atribuídas aos defeitos congênitos aumentaram proporcionalmente, passando da quinta para segunda causa. Hoje, é de relevância para a saúde pública, a exemplo do que acontece nos países desenvolvidos.
} 
Figura 8 - Transferência de agrotóxicos da mãe para o feto.

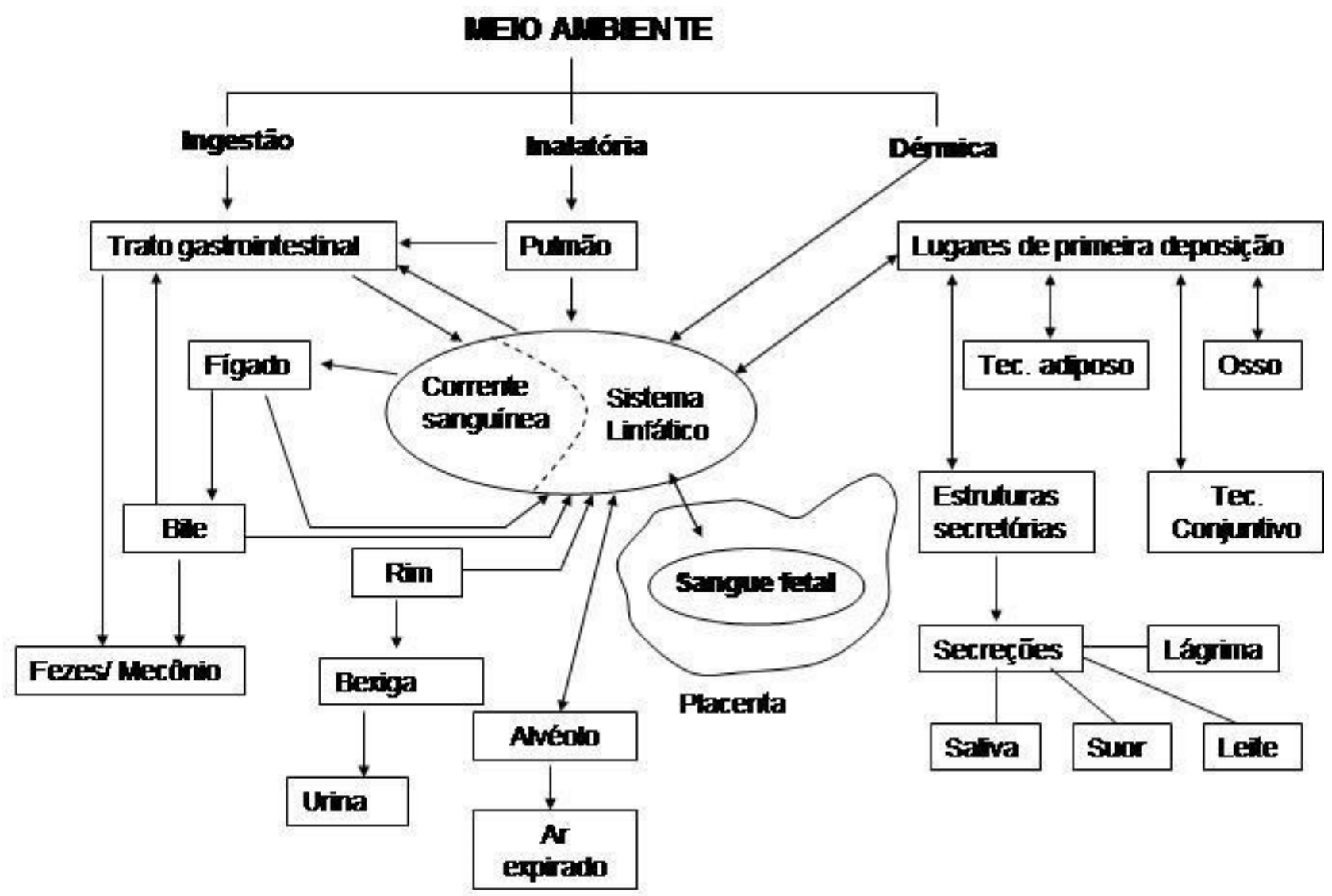

Fonte: Needham, 2005.

A imagem indica que a exposição materna ao agrotóxico pode acontecer por ingestão, inalação ou por contato dérmico. No processo de absorção, o organismo pode ou não metabolizar os agentes tóxicos, mas quando eles caem na corrente sanguínea, são facilmente transferidos para o feto por meio da placenta. Também é preocupante o fato de que alguns agrotóxicos podem ficar armazenados no organismo feminino, interferindo na fertilidade e/ou prejudicando o desenvolvimento do feto no período gestacional, uma vez que o bebê absorve tudo o que está no sangue da mãe (NEEDHAM, 2005).

Os estudos sobre os riscos que as exposições maternas aos agrotóxicos causam ao organismo, principalmente ao feto não são recentes. Investigações iniciaram a mais de 30 anos, tanto em animais, como por meio de estudos epidemiológicos (SUZUKI; MURAI, 1971; DMOCHOWSKA-MROCZEK; LEBENSZTEJN; TOLWINSKI, 1972; STANDIFER, 1974; MASLINSKA; ZALEWSKA, 1978).

Inclusive sobre a transmissão via placenta, Talbot, Fu e Hsieh (1988) investigaram por 
meio de estudo de caso em gestantes contaminadas, os níveis do herbicida Paraquat ${ }^{11}$ no sangue materno, fetal e do cordão umbilical, verificando que o tóxico atravessa a placenta e está concentrado em níveis 4-6 vezes maiores que o sangue materno. Além disso, o estudo mostrou níveis de Paraquat no líquido amniótico, em níveis quase o dobro do sangue materno. Nos seis casos que compuseram o estudo, todos os fetos morreram, independentemente de ter sido realizada ou não uma cesariana de emergência. Esse herbicida, frequentemente utilizado na agricultura só foi banido de uso no Brasil em 2017, quando a ANVISA reconheceu os riscos decorrentes de sua utilização, ainda sem clareza sobre a possibilidade de resíduos do produto nos alimentos (ANVISA, 2018).

Os estudos epidemiológicos em humanos, em sua maioria são observacionais, analisando a incidência de casos de alterações em gestantes e relacionando com a exposição a agrotóxicos. A exemplo, considera-se o estudo polonês que acompanhou gestantes expostas a produtos agrotóxicos, e verificou que as que apresentaram intoxicação aguda, apresentaram níveis do produto em seu sangue e de seu feto, os quais não sobreviveram (SANCEWICZPACH et al., 1997). Garry e colaboradores (2002) que observaram em estudos epidemiológicos, uma grande incidência de casos de aborto espontâneo entre mulheres de agricultores que manipularam fungicidas e herbicidas (GARRY et al., 2002).

Outro desfecho negativo identificado foi a redução do peso dos recém-natos que residem próximos a áreas agrícolas, em cujos cultivos foram utilizados agrotóxicos (XIANG; NUCKOLS; STALLONES, 2000). Resultados similares foram encontrados por Schreinemachers (2003) onde as mulheres apresentaram maiores riscos de ter um feto com malformação congênita, conforme estudo feito nos Estados Unidos. Há também indícios que a exposição ambiental gera alterações no sistema nervoso, causando rupturas neurais e comprometendo a transmissão neural e formação de redes neurais, com relação também para os problemas neuropsiquiátricos, onde se incluem o Transtornos do Espectro Autista (TEA), os déficits de atenção e hiperatividade (TDAH), e as dificuldades de aprendizagem (KAJTA; WOJTOWICZ, 2010).

Um estudo desenvolvido na China em 2012 ressaltou a relação entre a exposição a pesticidas e ocorrências na gravidez através de uma revisão bibliográfica realizada entre 1990 e 2012 (YAN et al., 2012), mostrando que a exposição a pesticidas aumentou os riscos de aborto espontâneo, parto prematuro e feto morto, porém não conseguiu estabelecer relação com

\footnotetext{
${ }^{11}$ Nome comercial: Gramoxone 200. É um composto quartenário do amônio utilizado como herbicida e altamente perigoso para os humanos, caso ingerido.
} 
ocorrências como morte fetal, defeitos de nascimento, baixo peso ao nascimento, morte neonatal e concepção atrasada.

Em estudo realizado no México durante uma campanha contra a Malária, avaliou-se a história reprodutiva de trabalhadoras expostas ao DDT, e na comparação do antes e depois à exposição foi verificado significativo aumento no risco de defeitos congênitos em bebês (SALAZAR-GARCIA et al., 2004).

Lorenz e colaboradores (2012), desenvolveu um estudo, impulsionado pelos alarmantes dados de crianças tailandesas nascidas com alteração do desenvolvimento neurológico, provavelmente, devido à exposição aos agrotóxicos pelas mães. A exposição aos agentes químicos na Tailândia está associada a práticas não seguras de uso e manuseio, bem como, são limitadas as informações sobre o conhecimento, as atitudes e práticas entre as gestantes grávidas sobre esses produtos, assim como em outros lugares do mundo. Os autores referem que essas informações são essenciais para compreender os fatores que estão associados com as exposições pré-natais de pesticidas, identificação das populações potencialmente em risco, e, finalmente, a partir disso proteger as mulheres grávidas e seus filhos. Esse estudo fez uso do protocolo KAP para obtenção dos dados, e confirmou a hipótese anteriormente levantada, de que aumentar o conhecimento das gestantes relacionados aos agrotóxicos pode ajudar a promover práticas seguras e reduzir a exposição pré-natal.

Nos Estados Unidos, bastou que o Instituto Nacional de Saúde e Segurança Ocupacional publicasse uma pesquisa que levantava suspeitas de que os inseticidas causavam danos aos fetos durante a gestação para que fossem melhorados os serviços de vigilância e as políticas de proteção à saúde das trabalhadoras agrícolas. No caso americano, três trabalhadoras tinham dado a luz a bebês com defeitos congênitos, num período de oito semanas cada e mesmo a investigação não conseguindo provar a relação entre a exposição ao inseticida e a gestação, o fato já constitui razão para que o governo americano promovesse atividades de prevenção e treinamento sobre como usar os pesticidas de forma adequada, evitando danos à saúde humana e ao meio ambiente (CALVERT et al., 2004; CALVERT; HIGGINS, 2010).

Em nível nacional, em 2003, foi realizado um estudo com prontuários de gestantes da região do Vale de São Lourenço no Sudoeste do país, no qual, pretendeu-se avaliar a presença de possíveis alterações sobre o desfecho da gravidez de mulheres expostas cronicamente de forma direta e/ou indireta a múltiplos agrotóxicos durante o período gestacional e foi possível observar na comparação, que as mulheres expostas deram à luz a crianças com peso e comprimento inferiores aos das mulheres que não trabalhavam na lavoura - a prevalência de baixo peso foi de $19 \%$ e pré-maturidade de $87 \%$ maior que o grupo controle. Esse trabalho 
possibilitou a conclusão de que a exposição crônica de mulheres a múltiplos agrotóxicos durante vários anos e, principalmente, durante o período gestacional, pode influenciar as alterações encontradas (FREIRE, 2005).

Também, em 2010, na região do Vale do São Francisco, em uma pesquisa caso-controle, o acompanhamento aos genitores expostos a agrotóxicos resultou em neonatos com mais defeitos congênitos, em populações com características sociodemográficas semelhantes (GONÇALVES et al., 2011).

$\mathrm{Na}$ região Sul realizou-se um estudo ecológico para investigar possíveis associações entre o consumo per capita de agrotóxicos por microrregiões e eventos adversos em nascidos vivos no período 1996-2000. Os dados foram obtidos junto ao Instituto Brasileiro de Geografia e Estatística (IBGE) e ao Departamento de Informática do SUS (DATASUS) e a análise se deu a partir das microrregiões. Foi verificado que nas microrregiões de maior consumo de agrotóxicos a ocorrência de nascimentos prematuros (menos de 22 semanas de gestação) e de índice de Apgar $1^{\circ}$ e $5^{\circ}$ minuto abaixo do desejado (média inferior a 8) apresentaram razões de prevalência significativamente maiores, tanto em meninos como em meninas. Estes achados sugerem a exposição intraútero a agrotóxicos como possível fator de risco para eventos adversos na gravidez, como parto prematuro e maturação inadequada (CREMONESE et al., 2014).

Em estudo semelhante realizado alguns anos depois, entre o período de 20 anos (1994 a 2014) nas bases de dados do Sistema de Informação sobre Nascidos Vivos (SINASC) do MS, reafirmou os resultados da pesquisa anterior, demonstrando que as regiões do estado do Paraná que mais consomem agrotóxicos, também possuem taxas mais elevadas de malformações congênitas (DUTRA; FERREIRA, 2017).

Além de todos esses efeitos teratogênicos causados pela exposição aos produtos agrotóxicos durante a gestação, que comprometem a saúde do feto, estudos, que iniciaram a cerca de 40 anos, tem apontado para a contaminação tóxica no leite materno (OLSZYNAMARZYS, 1978; PALMA, 2011). Isso ocorre porque parte dos agrotóxicos utilizados tem a capacidade de se dispersar no ambiente, e outra parte pode se acumular no organismo humano, inclusive no leite materno. $\mathrm{O}$ consumo do leite contaminado pode provocar agravos à saúde dos recém-nascidos, por sua maior vulnerabilidade à exposição a agentes químicos presentes no ambiente, por suas características fisiológicas e por se alimentarem quase exclusivamente com o leite materno até os 6 meses de idade.

Em uma pesquisa realizada na região Centro-Oeste do país, que ocupa destaque na agricultura, e consequentemente no consumo de agrotóxicos, com o objetivo de determinar 
resíduos de agrotóxicos no leite materno, participaram 62 lactantes com idade média de 26 anos, das quais 30\% residiam na zona urbana do município. Todas as amostras analisadas apresentaram pelo menos um tipo de agrotóxico analisado, e na maioria das amostras foi detectado mais de um tipo de agrotóxico. Os resultados podem ser oriundos da exposição ocupacional, ambiental e alimentar do processo produtivo da agricultura que expôs a população a 136 litros de agrotóxico por habitante na safra agrícola de 2010. Nessa exposição estão incluídas as gestantes e nutrizes, que podem ter sido contaminadas nesse ano ou em anos anteriores (PALMA, 2011; PIGNATI; MACHADO, 2011).

O mesmo ocorreu no leite animal, onde em outro estudo, foi realizada a análise de 209 amostras leite de vaca in natura, obtidas em quatro estados brasileiros - São Paulo (Botucatu), Paraná (Londrina), Minas Gerais (Viçosa) e Rio Grande do Sul (Pelotas), foi encontrado resíduos de inseticidas em 93,8\% das amostras avaliadas. Os resultados da pesquisa alertam para a possibilidade de transmissão da intoxicação para o leite, tanto em animais como em humanos, além de alertar para os riscos a que os consumidores estão sujeitos em decorrência da alta frequência de exposição a essas substâncias, que podem permanecer nos alimentos mesmo após a pasteurização ou esterilização (NERO et al., 2007).

\subsubsection{Políticas Públicas e o cuidado à gestante exposta a agrotóxicos}

A propósito da saúde materno-infantil, o Manual dos Comitês de Mortalidade Materna de 2007, em seu Anexo E, da Portaria n. ${ }^{\circ}$ 1.399, de 15 de dezembro de 1999, no que se refere às competências da União, estados, municípios e Distrito Federal, na área de epidemiologia e controle de doenças, define a sistemática de financiamento e dá outras providências, no capítulo XVII relata que é necessária coordenação das ações de vigilância ambiental de fatores de risco à saúde humana, incluindo o monitoramento da água para consumo humano e contaminantes com importância em saúde pública, como os agrotóxicos, mercúrio e benzeno.

Diferentes ações estão sendo tomadas em estados brasileiros, e no caso paranaense cabe citar a Política Estadual de Atenção Integral à Saúde do Trabalhador do Paraná publicada em 2011, mencionada anteriormente nesta revisão, a qual relata sobre as políticas públicas no campo da saúde do trabalhador, baseado nos princípios norteadores da Política Nacional de Saúde do Trabalhador - PNST, mas que no entanto, assim como em outras políticas sobre a saúde do trabalhador, é carente de enfoque na saúde materno-infantil (PARANÁ, 2011).

Buscando reverter essa situação, em 2018, o Estado do Paraná lançou a Linha Guia da Atenção às populações expostas aos agrotóxicos, como integrante do Plano de Vigilância e 
Atenção à Saúde de Populações Expostas aos Agrotóxicos do Estado do Paraná (PARANÁ, 2018). A proposta da Linha Guia é subsidiar tecnicamente os profissionais da rede de atenção primária para o acolhimento, diagnóstico, tratamento, notificação e acompanhamento da saúde dos trabalhadores e população exposta aos efeitos agudos e crônicos dos agrotóxicos no Estado do Paraná. A partir desse documento pretende-se garantir a essas pessoas uma rede de assistência com atendimento qualificado nas Atenções Primária, Secundária e Terciária e nos serviços de Urgência/Emergência, permitindo aos paranaenses uma saúde de qualidade.

Se nota que nesse documento, diferente dos anteriores as gestantes e as mulheres amamentando são contempladas como população de maior vulnerabilidade, e devem ser sinalizadas pelo diagnóstico situacional, e encaminhadas para assistência (PARANÁ, 2018).

Apesar disso, o que se nota a nível nacional ainda é uma carência de dados sobre o assunto, bem como sobre os sinais e sintomas de intoxicação nessa população e ainda sobre o conhecimento das consequências que a exposição pode gerar tanto a mãe quanto o feto ainda são precários.

O acompanhamento pré-natal é considerado fundamental para a saúde do binômio, tanto no que se refere a prevenção de agravos, promoção de hábitos adequados, e minimização de danos ocorrido em virtude de diversas causas, dentre elas, as exposições ambientais. Uma revisão bibliográfica realizada entre os anos de 2005 e 2015 mostrou aumento da cobertura da atenção pré-natal ao longo dos últimos dez anos em quase todo país, a despeito da qualidade, no entanto, constatou-se baixos índices no que se refere a adequação do sistema, por motivos que vão desde a não realização do número ideal de consultas e início precoce da assistência até, principalmente, a ausência de promoção do conteúdo quantitativo e qualitativo preconizado para essas consultas (NUNES et al,. 2016).

Em outro estudo, o objetivo foi avaliar a adequação do cuidado pré-natal no Brasil associado a determinantes sociodemográficos, por meio da análise dos dados da Pesquisa Nacional de Saúde realizada no Brasil em 2013. Os resultados evidenciaram que cerca de $80 \%$ das mulheres realizaram o pré-natal adequado e $70 \%$ realizam os exames essenciais (MARIO, 2013).

É competência do MS estabelecer políticas e normas para oferta do pré-natal com boa qualidade. Além dos equipamentos e instrumental para realização das consultas e exames, devese levar em conta a capacitação adequada de todas as pessoas que atendem a mulher no seu percurso pela unidade de saúde (BRASIL, 2000).

O acompanhamento tem por objetivo diminuir os riscos de complicações e mantém o bem-estar da mãe e do feto, e contempla anamneses, consultas, avaliações físicas e outros 
exames, que devem ser realizados em laboratório de análises clínicas e medicina diagnóstica. Ao todo, durante os quase nove meses são realizadas cerca de sete consultas cobertas pelo SUS, distribuídas entre os três trimestres (SERRUYA et al., 2004).

No entanto, na própria cartinha de instrução do MS sobre o pré-natal não consta cuidado especifico a gestante exposta a agrotóxicos, e nem esse, é considerado como fator de risco, intermediário ou alto (BRASIL, 2000).

Diante dessa realidade se constata que mesmo com programas de cobertura significativa em nosso país, como a Rede Amamenta Brasil, Rede Cegonha e Programa de Humanização do Pré-natal e Nascimento, além dos demais programas oriundos desses, desenvolvidos pelos estados, a citar a Rede Mãe Paranaense no Estado do Paraná e a Rede Mãe Paulistana em São Paulo, é possível notar carência de atenção a mulher agricultora, considerada população de risco devido a exposição aos produtos agrotóxicos (BRASIL, 2000; 2012; SÃO PAULO, 2008; PARANÁ, 2012). Por esse motivo, dentre outros, apesar da ampla cobertura, o pré-natal no Brasil ainda apresenta iniquidades e baixa qualidade no atendimento, especialmente entre mulheres das regiões mais pobres do país e em regiões rurais. 


\subsection{VALIDAÇÃO DE INSTRUMENTOS}

Nesse capítulo apresenta-se um breve referencial teórico sobre o processo de tradução e adaptação de instrumentos de pesquisa, detalhando como se deu a aplicabilidade do instrumento utilizado nesse estudo, desde sua tradução em pesquisa anterior, até sua validação - a presente pesquisa - a qual os resultados são apresentados no Capítulo 5 - Resultados nesta tese. Além disso, são apresentados estudos que comprovam a aplicabilidade do CAP em suas diferentes modalidades de pesquisa.

\subsubsection{Processo de Tradução e adaptação de protocolos}

Os questionários são considerados importantes instrumentos para o enfrentamento de diversos problemas, principalmente no que se refere a atenção e cuidado da saúde. Seu uso por profissionais da saúde tem crescido significativamente nos últimos anos, no entanto, para ser considerado de fácil aplicação e garantia de confiabilidade de seus resultados, um processo criterioso de análise do instrumento é necessária (TOMASCHEWSKI et al., 2015; FREIRE; ARREGUY-SENA; MULLER; 2017).

A utilização de questionários, possibilita a implantação de protocolos clínicos, que auxiliam os profissionais da saúde na tomada de decisões, sejam elas simples ou complexas, que possuam paradigmas clínicos e subsídios teóricos realmente confiáveis para que possam ser aplicados na população desejada, e atinja o objetivo esperado. Tais ferramentas são elaboradas por meio de um amplo estudo sistemático das evidências científicas de determinada conduta, envolvendo pesquisadores, professores e demais especialistas, a fim de trazer resultados consensuais em relação a discussões de trabalhos clínicos que possam ser usados para melhorar o direcionamento de ações de promoção e prevenção da saúde, por meio da maior rapidez, confiabilidade, normalização e segurança à assistência.

Esses instrumentos podem ser utilizados como guia principal ou auxiliar ao profissional da saúde, por serem ferramentas dinâmicas e sensíveis na captação do objeto desejado, baseado em evidências previamente comprovadas.

Na pesquisa científica, a coleta de dados sistemática desempenha um papel fundamental para a qualidade e o tempo do estudo científico, tornando-se um tema de interesse para os pesquisadores (VAN GELDER; BRETVELD; ROELEVELD, 2010). O acesso crescente à internet em todo o mundo, possibilitou a realização de pesquisas por meio do ambiente virtual, emergindo uma nova tendência para a coleta de dados, que apresenta vantagens como a rápida 
análise dos resultados, redução no tempo e período da aplicação, além da facilidade para os sujeitos do estudo, que podem responder ao questionário a qualquer hora e em qualquer lugar (GALEA; TRACY, 2007; ZUIDGEEST et al., 2011). Entretanto, desvantagens também podem ser observadas, tais como, a ausência de respostas e a confiabilidade dos dados obtidos (VAN GELDER; BRETVELD; ROELEVELD, 2010).

De maneira geral, os instrumentos de coleta de dados, para serem efetivamente utilizados na prática profissional, devem passar por um processo rigoroso de tradução, adaptação e validação. Comumente, se nota a necessidade de utilizar protocolos internacionais, tanto pela facilidade em se usar um instrumento já elaborado e validado, quanto pela possibilidade de comparação entre as populações. Contudo, para que um questionário seja utilizado como instrumento em uma pesquisa, uma análise criteriosa precisa ser realizada.

A crescente demanda na tradução de instrumentos estrangeiros reflete a carência de ferramentas nacionais disponíveis, no entanto, também contribui para a realização de estudos transculturais, que podem trazer maiores esclarecimentos e compreensão acerca de diferentes questões sobre a saúde humana e seus cuidados (GIUSTI; BEFI-LOPES, 2008).

Embora a tradução e adaptação de instrumentos estrangeiros seja considerada uma alternativa com respaldo científicos, é importante destacar que os procedimentos adotados neste processo devem ser criteriosos e cuidadosos, principalmente porque a tradução e adaptação são tão importantes quanto a construção de um novo instrumento, principalmente devido as diferenças culturais, que não permite que se faça uma simples tradução (ALEXANDRE; GUIRARDELLO, 2002; GIUSTI; BEFI-LOPES, 2008).

O termo "adaptação transcultural" é utilizado para caracterizar o processo de tradução e adaptação de um instrumento original, tendo em vista sua aplicação em outro contexto. Entre as diversas vantagens para a aplicação de um questionário preexistente, podemos destacar a rapidez e facilidade quando comparado a criação de um novo instrumento, além da possibilidade de se ter um instrumento importante disponível em várias linguagens, permitindo estudos internacionais e comparações entre populações de origens e línguas diferentes (SPERBER, 2004).

Historicamente, a adaptação de instrumentos elaborados em uma outra cultura e/ou idioma se detinha à simples tradução do original ou, excepcionalmente, à comparação literal desta com uma retradução. Recentemente, pesquisadores de diferentes áreas temáticas vêm sugerindo que a avaliação semântica constitua apenas um dos passos necessários ao processo de adaptação transcultural (BADIA; ALONSO, 1995; REICHENHEIM; MORAES, 2007). É necessário, além da tradução, o ajuste do instrumento quanto a palavras e termos, dentro do 
contexto cultural, transformando, em muitos casos, alguns itens por completo, para que seja possível capturar o mesmo conceito (GUILLEMIN, 1995; SPERBER, 2004).

Beaton e colaboradores (2000) propõem uma série de métodos para proceder a tradução e adaptação cultural: tradução, síntese, back translation, revisão por um comitê de especialistas, pré-teste e verificação das propriedades psicométricas (BEATON et al., 2000):

- Tradução: a primeira etapa do processo é a tradução, quando o instrumento vai ser utilizado em outro idioma. Nessa etapa, sugere-se que a tradução direta seja realizada por pelo menos dois indivíduos que dominem bem o idioma original e aquele para o qual o instrumento será traduzido. Dessa forma, é possível a comparação entre ambas as versões, minimizando discrepâncias que podem causar divergências na versão traduzida. Quando ocorrem diferenças, presa-se pelo consenso entre ambos os tradutores.

- Síntese: Na síntese da versão traduzida os dois tradutores e uma terceira pessoa envolvida no processo procuram sintetizar os resultados das traduções. Essa etapa possibilita que a versão sintetizada, ou seja, traduzida, preserve o significado de cada item do instrumento original, originando a produção de um único instrumento final.

- Retro-tradução (Back translation): A partir da síntese obtida, outros dois tradutores que não conhecem a versão original do instrumento, realizaram nova tradução para o idioma original do mesmo. Esses tradutores devem ter a língua materna no idioma no qual será traduzido, inglês, por exemplo, e devem ter domínio da língua portuguesa, além de desconhecerem totalmente a versão original do instrumento, bem como, sobre a área de estudo (saúde, por exemplo). Essa criteriosidade permite uma das etapas de validação do instrumento, que verifica se a versão obtida reflete o mesmo conteúdo da versão original. Em geral, esta etapa permite verificar as inconsistências e os erros conceptuais feitos durante a tradução. Após essa etapa, deve ser realizada uma síntese da retro-tradução, objetivando selecionar as frases mais adequadas e de melhor expressão, comparando as versões

- Comitê de especialistas: A composição desse comitê é fundamental para se obter a plena adaptação cultural do instrumento. Nessa etapa incluem-se profissionais com experiência nesse tipo de estudo, com conhecimentos da área de saúde, de metodologia, de linguística e que conheçam bem os dois idiomas envolvidos. O comitê tem a missão de consolidar todas as versões: original, traduzidas, retrotraduzidas e suas 
sínteses, desenvolvendo uma versão pré-final do instrumento testado, por meio do consenso quanto à equivalência semântica, idiomática, funcional e conceitual (BEATON et al., 2000).

a) Equivalência semântica: Identifica se as palavras apresentam o mesmo significado da versão original, se existe mais de um significado para cada item do instrumento e se estes itens podem gerar ambiguidade. Avalia se houveram dificuldades gramaticais em alguma das etapas de tradução.

b) Equivalência idiomática: Avalia quais as expressões ou linguagens coloquiais que são de difícil tradução. Sendo assim, estas devem ser substituídas por expressões equivalentes na cultura alvo.

c) Equivalência funcional: Avalia o contexto cultural da população alvo, ou seja, os itens do questionário adaptado devem reproduzir as experiências descritas na versão original, no entanto, deve ser substituído por expressões do contexto da cultura alvo.

d) Equivalência conceitual: Algumas palavras apresentam diferentes significados conceituais entre culturas, esta equivalência serve para avaliar o significado conceitual de palavras ou expressões quando semelhantes e comparar os contrastes culturais.

Nessa etapa o comitê de especialistas deve consolidar todas as versões do instrumento e definir aquela que será a versão a ser submetida ao pré-teste (BEATON et al., 2000).

- Pré-teste: Estando concluída a versão obtida pelo comitê de especialistas, o instrumento deverá ser aplicado em um grupo inicial de sujeitos que fazem parte da população-alvo a ser pesquisada. Cada sujeito, após completar o instrumento, relata ao aplicador sua interpretação sobre cada uma das questões e suas respostas para avaliar se o instrumento adaptado detém a equivalência no contexto em que esta sendo aplicado o que ele acredita que cada item e cada resposta significam.

\subsubsection{Validação de Instrumentos}

Inclui-se no processo de adaptação transcultural, assim como após a criação de um protocolo, a validação. Nesse processo examina-se a precisão de uma determinada predição ou inferência realizada a partir dos escores de um teste. Raymundo (2009) descreve que validar, 
mais do que a demonstração do valor de um instrumento de medida, é todo um processo de investigação, sendo o que o mesmo não se esgota, do contrário, pressupõe continuidade e deve ser repetido inúmeras vezes para o mesmo instrumento. Além disso, segundo o autor, no processo de validação não se valida propriamente o teste, mas a interpretação dos dados decorrentes de um procedimento específico, na qual, a cada aplicação de um instrumento, pode corresponder, portanto, uma interpretação dos resultados (RAYMUNDO, 2009).

$\mathrm{O}$ autor supracitado ainda reitera que a validade de um protocolo começa no momento em que se pensa em construí-lo, e se mantém durante todo o processo de elaboração, aplicação, correção e interpretação dos resultados.

O processo de validação de um instrumento, nada mais é do que avaliação das propriedades psicométricas do mesmo, a fim de verificar se as características do instrumento original foram mantidas. Portanto, a versão final do instrumento traduzido e adaptado deve ser aplicada de forma a mensurar as características de confiabilidade e de validade dos resultados obtidos. A versão adaptada deverá apresentar performance semelhante à original (GUILLEMIN, 1995; BEATON et al., 2000; SPERBER, 2004).

\subsubsection{Confiabilidade}

A confiabilidade, também denominada fidedignidade ou previsão de um teste, é considerada um aspecto fundamental para avaliar a qualidade de um instrumento, e refere-se a característica que ele deve possuir, a saber, medir sem erros. Isso significa que o mesmo teste, medindo os mesmos sujeitos em ocasiões diferentes, ou testes equivalentes, medindo os mesmos sujeitos na mesma ocasião, produzem resultados idênticos, isto é, a correlação entre estas duas medidas deve ser igual (PASQUALI, 2011). No entanto, essa medida não é uma propriedade fixa, uma vez que, depende da função do instrumento, da população em que é administrado, das circunstâncias, do contexto, ou seja, o mesmo instrumento pode não ser considerado confiável segundo diferentes condições (KESZEI; NOVAK; STREINER, 2010). Além disso, essas estimativas são afetadas por diversos aspectos do ambiente de avaliação (avaliadores, características da amostra, tipo de instrumento, método de administração) e pelo método estatístico utilizado (ROACH, 2006). Ou seja, a confiabilidade refere-se a quão estável, consistente ou preciso é um instrumento (POLIT; BECK, 2011). A escolha dos testes estatísticos usados para avaliar a confiabilidade pode variar, dependendo do que se pretende medir (KESZEI; NOVAK; STREINER, 2010).

Para medir a confiabilidade, geralmente são utilizados três critérios: 
a) Estabilidade: é o grau em que resultados similares são obtidos em dois momentos distintos, ou seja, é a estimativa da consistência das repetições das medidas. Essa medida por ser obtida por meio do método de teste-reteste, que consiste na aplicação de uma mesma medida em dois momentos, e espera-se que os resultados obtidos das duas aplicações sejam similares (POLIT; BECK, 2011). Uma variável importante nesse procedimento é o tempo entre as aplicações, que não pode ser nem muito próximo, nem muito prolongado, sendo considerado por alguns autores um intervalo adequado entre 10 a 14 dias entre o teste e o reteste (KESZEI; NOVAK; STREINER, 2010). Quanto à amostra, um número de pelo menos 50 sujeitos é considerado adequado (TERWEE et al., 2007). O coeficiente de correlação interclasse (intraclass correlation coeficiente - ICC) é um dos teste mais utilizados para estimar a estabilidade, e, quanto à interpretação dos resultados desse teste, valores mínimos de 0,70 são considerados satisfatórios (TERWEE et al., 2007).

b) Consistência interna: também denominada de homogeneidade - indica se todas as subpartes de um instrumento medem a mesma característica (STREINER, 2003). Trata-se de uma importante propriedade de medida para instrumentos que avaliam um único construto, utilizando, para isso, uma diversidade de itens (TERWEE, et al., 2007). Uma estimativa de consistência interna baixa pode significar que os itens medem construtos diferentes ou que as respostas às questões do instrumento são inconsistentes (KESZEI; NOVAK; STREINER, 2010). A maioria dos pesquisadores avalia a consistência interna de instrumentos por meio do coeficiente alfa de Cronbach (KESZEI; NOVAK; STREINER, 2010; STREINER; KOTTNER, 2014). Esse coeficiente reflete o grau de covariância entre os itens de uma escala, ou seja, quanto menor a soma da variância dos itens, mais consistente é considerado o instrumento (PASQUALI, 2013). Segundo a literatura, valores abaixo de 0,70 - mas próximos a 0,60 - são considerados como satisfatórios (STREINER, 2003; PASQUALI, 2011). No entanto, esses valores são influenciados pelo número de itens do instrumento, sendo que poucos itens por domínio pode diminuir os valores de alfa, afetando sua consistência interna.

c) Equivalência: refere-se ao grau de concordância entre dois ou mais observadores quanto aos escores de um instrumento, e a maneira mais tradicional de se avaliar isso, é a confiabilidade interobservadores. Nessa avaliação, o instrumento é preenchido por dois ou mais avaliadores, e a análise se dá pela concordância entre as respostas dos avaliadores (POLIT; BECK, 2011). A confiabilidade interobservadores 
depende, principalmente, de um treinamento adequado dos avaliadores e de uma padronização da aplicação do teste (AARONSON et al., 2002). O coeficiente Kappa é uma medida utilizada para avaliação interobservadores, aplicado a variáveis categóricas, por meio de uma medida de concordância entre os avaliadores e assume valor máximo igual a 1,00 e quanto maior o valor de Kappa, maior a concordância entre os observadores. Valores próximos ou abaixo de 0,00 indicam a inexistência de concordância (HEALE; TWYCROSS, 2015).

É importante ter clareza de que a confiabilidade de um instrumento deve ser sempre discutida em função da população e do propósito do estudo, uma vez que um instrumento confiável para um conjunto de situações pode não ter a mesma confiabilidade em circunstâncias diferentes, razão pela qual a confiabilidade e a validade devem ser testadas sempre (KESZEI; NOVAK; STREINER, 2010).

\subsubsection{Validade}

A validade refere-se ao fato de um instrumento medir exatamente o que se propõe a medir (ROBERTS; PRIEST, 2006; MOKKINK et al., 2010). Não se trata de uma característica do instrumento, mas é determinada em relação a uma questão particular, uma vez que se refere a uma população definida $(\mathrm{ROACH}, 2006)$. As propriedades de medida - validade e confiabilidade - não são totalmente independentes, uma vez que um instrumento não confiável não pode ser válido; entretanto, um instrumento confiável pode, às vezes, não ser válido (KIMBERLIN; WINTERSTEIN, 2008; POLIT; BECK, 2011). Quanto aos tipos de validade, serão abordados no presente estudo os três principais: validade de conteúdo, validade de critério e validade de construto:

- Validade de conteúdo: refere-se ao grau em que o conteúdo de um instrumento reflete adequadamente o construto que está sendo medido, ou seja, é a avaliação do quanto uma amostra de itens é representativa de um universo definido ou domínio de um conteúdo (POLIT; BECK, 2011; POLIT, 2015). Trata-se de uma análise qualitativa, que resulta do julgamento de diferentes examinadores especialistas (comitê de especialistas), que analisam a representatividade dos itens em relação às áreas de conteúdo e à relevância dos objetivos a medir, mas que não pode ser determinada estatisticamente. Essa análise é obtida pelo Índice de Validade de Conteúdo (IVC), que mede a proporção ou porcentagem de juízes em concordância sobre determinados aspectos de um instrumento e de seus itens (ALEXANDRE, COLUCI, 2011). Este método consiste de uma escala de Likert com pontuação de 1 a 4, em que: 1 = item 
não equivalente; 2 = item necessita de grande revisão para ser avaliada a equivalência; 3 = item equivalente, necessita de pequenas alterações; e 4 = item absolutamente equivalente (COLUCI, ALEXANDRE, MILANI, 2015). Os itens que receberem pontuação de 1 ou 2 devem ser revisados ou eliminados. Para calcular o IVC de cada item do instrumento, basta somar as respostas 3 e 4 dos participantes do comitê de especialistas e dividir o resultado dessa soma pelo número total de respostas. O índice de concordância aceitável entre os membros do comitê de especialistas deve ser de no mínimo 0,80 e, preferencialmente, maior que 0,90 (POLIT; BECK, 2006). É importante lembrar que a validação do conteúdo não é permanente, mas sofre os efeitos do transcurso do tempo e em função de modificações na filosofia educacional e/ou na estrutura curricular que o instrumento procura refletir.

- Validade de Critério: A validade de critério consiste na relação entre pontuações de um determinado instrumento e algum critério externo (KIMBERLIN; WINTERSTEIN, 2008). Em avaliações da validade de critério, é testado a validade de uma medida comparando-se os resultados da medida com um 'padrão-ouro' ou critério estabelecido (ROACH, 2006). Ela é organizada em preditiva ou concorrente e refere-se ao grau de correlação entre os escores de um teste e outras medidas do desempenho (critério) obtidas independentemente ou simultaneamente ao teste. Quando o instrumento e o critério são aplicados simultaneamente, fala-se de validade concorrente; quando o critério é avaliado no futuro, fala-se de validade preditiva. A validade de critério pode ser constatada por um coeficiente de correlação (POLIT; BECK, 2011). As pontuações do instrumento de medida são correlacionadas com os escores do critério externo e esse coeficiente é analisado (KEIZEI; NOVAK; STREINER, 2010). Valores próximos a 1,00 indicam haver correlação, enquanto valores próximos de 0,00 indicam que não existe correlação. São desejáveis coeficientes de correlação de 0,70 ou superiores (POLIT; BECK, 2011).

- Validade de Constructo: é a extensão em que um conjunto de variáveis realmente representa o construto a ser medido (MARTINS, 2006; SOUZA; ALEXANDRE; GUIRARDELLO, 2017). Para se estabelecer a validade de construto, geram-se previsões com base na construção de hipóteses, e essas previsões são testadas para dar apoio à validade do instrumento (SOUZA; ALEXANDRE; GUIRARDELLO, 2017). Quanto mais abstrato o conceito, mais difícil é estabelecer a validade de construto (POLIT; BECK, 2011). Sendo assim, as evidências necessárias para esse tipo de validação são obtidas fazendo-se uma série de estudos inter-relacionados, por meio de testes estatísticos, das construções teóricas sobre a relação entre as variáveis a serem medidas. A constatação da validade de construto resulta do acúmulo, por diferentes meios, de várias provas, que precisam ser analisadas em todos os seus 
detalhes. Esse tipo de validação visa detectar, entre outros aspectos, quais as variáveis com as quais os escores do teste se correlacionam, quais os tipos de itens que integram o teste, o grau de estabilidade dos escores sob condições variadas e o grau de homogeneidade do teste, com vistas a ter elementos que possam esclarecer o significado do instrumento (MARTINS, 2006; POLIT; BECK, 2011). Pesquisadores subdividem a validade de construto em três tipos: teste de hipóteses, validade estrutural ou fatorial e validade transcultural (MOKKINK et al., 2010; POLIT, 2015)

É importante destacar que a validação de construto não se limita a validar um teste; o seu alcance é bem mais amplo, centrando-se o seu objetivo na validação da teoria em que se apoiou a construção do instrumento. Esse tipo de validade é estudado quando o investigador deseja entender melhor as questões cognitivas e psicológicas que estão sendo medidas pelo teste (SOUZA; ALEXANDRE; GUIRARDELLO, 2017).

Considerando o exposto neste capítulo, é evidente a necessidade de se seguirem diretrizes específicas em processos de tradução e adaptação transcultural na área da saúde, que considerem as especificidades de cada língua e pais, respeitando suas culturas e valores, e que tais, mesmo com as suas variações possam ser unificadas em um instrumento de medida.

\subsubsection{Aplicabilidade dos protocolos CAP - Conhecimento, Atitudes e Práticas}

Estudos que verificam o Conhecimento, a Atitude e as Práticas (CAP) da população vem sendo aplicada mundialmente em estudos com as mais diversas populações. Essa metodologia CAP permite diagnosticar uma população a partir do seu conhecimento, sua atitude e de sua prática, de forma a mostrar o que as pessoas sabem, sentem e também como se comportam a respeito de um determinado tema. Ela também permite um levantamento de dados que proporcionem a identificação dos melhores caminhos para a formulação de futuras estratégias intervencionistas a serem aplicadas no grupo estudado (CABANA et al., 1999; BRASIL, 2002).

De maneira global, compreende-se a definição dos conceitos como (MARINHO, 2001):

- Conhecimento: significa recordar fatos específicos ou a habilidade de aplicar fatos conhecidos para a solução de problemas ou, ainda, emitir conceitos que podem permear o tema. 
- Atitude: compreende essencialmente sobre ter opinião, sentimentos e predisposições e crenças, relativamente constantes, dirigidos a um objetivo, pessoa ou situação, bem como, conceitos que podem permear o tema.

- Prática: é a tomada de decisão para executar a ação, relaciona-se em uma dimensão social aos domínios psicomotor, afetivo e cognitivo.

Compreender os níveis de conhecimento, atitude e prática de uma determinada população é fundamental, uma vez que além de facilitar no processo de criação de sua consistência crítica e na autonomia do controle do seu processo saúde-doença, permite ainda o reconhecimento das reais necessidades ou problemas da população, possibilitando uma adequação das possíveis intervenções, direcionando-as para a problemática em questão (BRASIL, 2002).

O inquérito CAP se trata de uma avaliação formativa, que objetiva coletar dados de uma parcela populacional e favorecer a elaboração de intervenções (BRASIL, 2002). É possível encontrar diversos trabalhos com a aplicação do mesmo, em diversas populações. Esse protocolo se difere de acordo com a área e o tipo de estudo, mas em suma, todos procuram investigar os aspectos de conhecimento, atitude e prática sobre determinado assunto (CABANA, et al., 1999; NICOLAU et al., 2012; COSTA, 2012).

No Brasil, vários estudos realizados, abordando diversas temáticas na área da saúde, utilizam a metodologia CAP e enfatizam a sua importância na identificação de problemas e elaboração de estratégias viáveis para cada realidade encontrada. Esses estudos, permitem a identificação de lacunas no conhecimento, crenças culturais e/ou padrões de comportamentos que podem promover ou impedir a compreensão e ação de um problema de saúde pública. Também podem ser utilizados para identificar as necessidades e problemas de uma população e as barreiras na implementação de intervenções e programas, bem como propor soluções para melhoria da qualidade e acesso aos serviços de saúde (WHO, 2008).

Em uma revisão bibliográfica sobre estudos publicados que utilizaram a metodologia CAP, foi possível perceber o quão relativamente nova e ainda pouco utilizada ela é. Nessa revisão, a maioria dos estudos analisados foi realizada no Brasil (45,4\% dos artigos selecionados) e o período de maior concentração das publicações foi entre os anos de 2005 e 2011. Os resultados permitiram inferir que a aplicabilidade da metodologia CAP é bastante ampla, abrangendo diversas temáticas da área da saúde e permite um diagnóstico situacional de uma determinada população a partir da identificação de seus problemas e necessidades, possibilitando assim a elaboração de intervenções (COSTA, 2012). 
Em uma outra revisão bibliográfica realizada anteriormente, sobre a adoção de protocolos clínicos por profissionais da saúde, identificou-se barreiras relacionadas ao conhecimento, atitude e prática. A falta de acesso e conhecimento dos protocolos, o volume de informações e o tempo necessário para se manter informado foram barreiras relacionadas ao conhecimento. A não concordância e falta de confiança nos protocolos e a ausência de motivação estão relacionadas à falta de atitude dos profissionais. Em relação à prática, as barreiras identificadas foram as características dos pacientes, fatores externos, falta de tempo e recursos e problemas organizacionais e dos próprios protocolos (CABANA et al., 1999).

Em um estudo brasileiro realizado com estudantes adolescentes de escolas públicas de Maceió, no estado do Alagoas, utilizou-se o questionário a fim de investigar os conhecimentos, práticas e atitudes referentes a alguns aspectos da sexualidade, e os resultados com esse estudo, possibilitou a proximidade com o ambiente jovem e a descrição dos seus principais medos, inseguranças, bem como, avaliar os seus conhecimentos sobre o assunto, e que atitudes tomam sobre o mesmo. Também sugeriu a implantação de debates de temas sobre saúde sexual e reprodutiva nas escolas, voltado para alunos, pais e professores, de forma a fornecer subsídios suficientes para diminuir as dúvidas dos adolescentes e preparar os pais e professores para melhor orientar e conviver com este grupo etário (LEITE, 2001).

Outro trabalho se ateve a investigar os conhecimentos, atitudes e comportamentos para hipertensão arterial entre adultos de uma comunidade de baixa renda, situada em Caucaia, no Ceará, estado de Pernambuco, e as razões que norteiam as suas atitudes com relação aos fatores de risco comportamentais tabagismo, hábito de ingerir bebidas alcóolicas, ingestão de sal e gorduras na dieta e a prática de exercícios físicos. Os achados revelaram que as razões norteadoras dos comportamentos e atitudes investigadas estão ligadas a emoções, a questões sociais e econômicas. As mudanças comportamentais representam o abandono de alguns prazeres para pessoas que lutam para sobreviver em condições de vida de pobreza, e que viver em situação de pobreza interfere nas possibilidades de mudança de comportamentos (LIMA; BUCHER; LIMA, 2004).

Acerca das mulheres, em um estudo que teve por objetivo identificar o conhecimento, a atitude e a prática de mulheres residentes em uma comunidade rural quanto a métodos contraceptivos, o inquérito CAP foi utilizado como metodologia, onde participaram predominantemente mulheres jovens, unidas com seus parceiros, com baixa escolaridade e renda, permitiu verificar que as características culturais, sociodemográficas e as circunstâncias vivenciadas influenciaram o conhecimento, atitude e uso de métodos contraceptivos e, consequentemente, a sua história reprodutiva (NICOLAU et al., 2012). 
Em trabalho realizado com gestantes, Candeias (1980) buscou identificar o conhecimento, as atitudes e as práticas de mulheres grávidas em relação aos acompanhamentos médicos pré-natais, reconhecendo as razões que impediram o comparecimento as consultas e a utilização dos serviços de saúde, e entre elas destacam-se principalmente as inconsistências entre atitudes e práticas da população em estudo.

Outro trabalho com mulheres evidenciou a adequação dos conhecimentos, atitudes e práticas em relação ao exame Papanicolau, destacando a ausência de sintomas e a vergonha como as principais barreiras para realização do procedimento, e evidenciando que as mulheres que praticam consultas periodicamente apresentam práticas mais adequadas, porem com baixa adequação de conhecimento frente ao procedimento, sugerindo que não estejam recebendo as informações adequadas sobre os benefícios da realização periódica desse exame (ALBUQUERQUE, 2014).

Recena e Caldas (2008) avaliaram a percepção de risco, práticas e atitudes dos agricultores diante dos produtos e concluíram que esses indivíduos nem sempre transformam sua percepção de risco e suas experiências pessoais em atitudes e práticas mais seguras no uso de agrotóxicos. Por meio deste estudo foi possível verificar que os agricultores, apesar de se mostrarem cientes dos riscos, preocupam-se com a contaminação, mas as informações que tinham sobre agrotóxicos eram restritas, demonstrando que esses agricultores, muitas vezes, se sentem indefesos diante das situações de risco, principalmente devido aos fatores ambientais não controláveis e à vulnerabilidade econômica. Foi possível constatar que são essenciais programas governamentais de extensão agrícola que enfatizem técnicas alternativas de manejo de pragas e práticas seguras de uso de agrotóxicos, direcionados a essa população (RECENA; CALDAS, 2008).

Ainda sobre o tema agrotóxico, outro trabalho também na região Centro-Oeste brasileira, a análise do conhecimento, atitudes e práticas em relação ao uso de agrotóxicos e os níveis de exposição dos agricultores e suas famílias a diversos inseticidas em duas comunidades rurais, possibilitou verificar que a maioria dos agricultores, que sobrevivem da agricultura familiar acredita que os agrotóxicos podem fazer mal a saúde, entretanto, mais da metade relata raramente fazer uso de equipamentos de proteção individual (RECENA et al., 2006).

Associado a aplicação do questionário, Pasiani (2012) realizou análise sanguínea para verificar os níveis de intoxicação endógena no organismo, e encontrou níveis elevados de agentes tóxicos no organismo, bem como a presença de alterações renais e hepáticas. Novamente, afirmou-se a necessidade de programas de educação no sentido de promover o uso 
seguro dos agrotóxicos no campo e proteger os agricultores e seus familiares da exposição aos agrotóxicos.

O protocolo KAP para gestantes foi proposto na versão em inglês por Lorenz e colaboradores (2012). O artigo teve como objetivo investigar as informações referentes a fatores associados com exposição pré-natal de agrotóxicos, identificar as populações potencialmente em risco, e, para com isso, desenvolver estratégias que auxiliem na proteção das mulheres grávidas e seus filhos. A pesquisa concluiu que aumentar o conhecimento das gestantes pode ajudar a promover práticas mais seguras e reduzir a exposição pré-natal.

\subsubsection{Apresentação do Questionário CAP em português - Processo de Tradução e retrotradução do instrumento}

O processo de tradução do questionário CAP, foi desenvolvido durante uma pesquisa de Mestrado, por Cassol e Magni (2015), e seguiu os procedimentos apresentados nesta revisão (Figura 9). 
Figura 9 - Ilustração resumida do processo de tradução do questionário CAP (CASSOL \& MAGNI, 2015)

\section{PROCESSO DE TRADUÇÃO E RETROTRADUÇÃO CAP- Conhecimento, Atitudes e Práticas}

(Cassol e Magni, 2015)

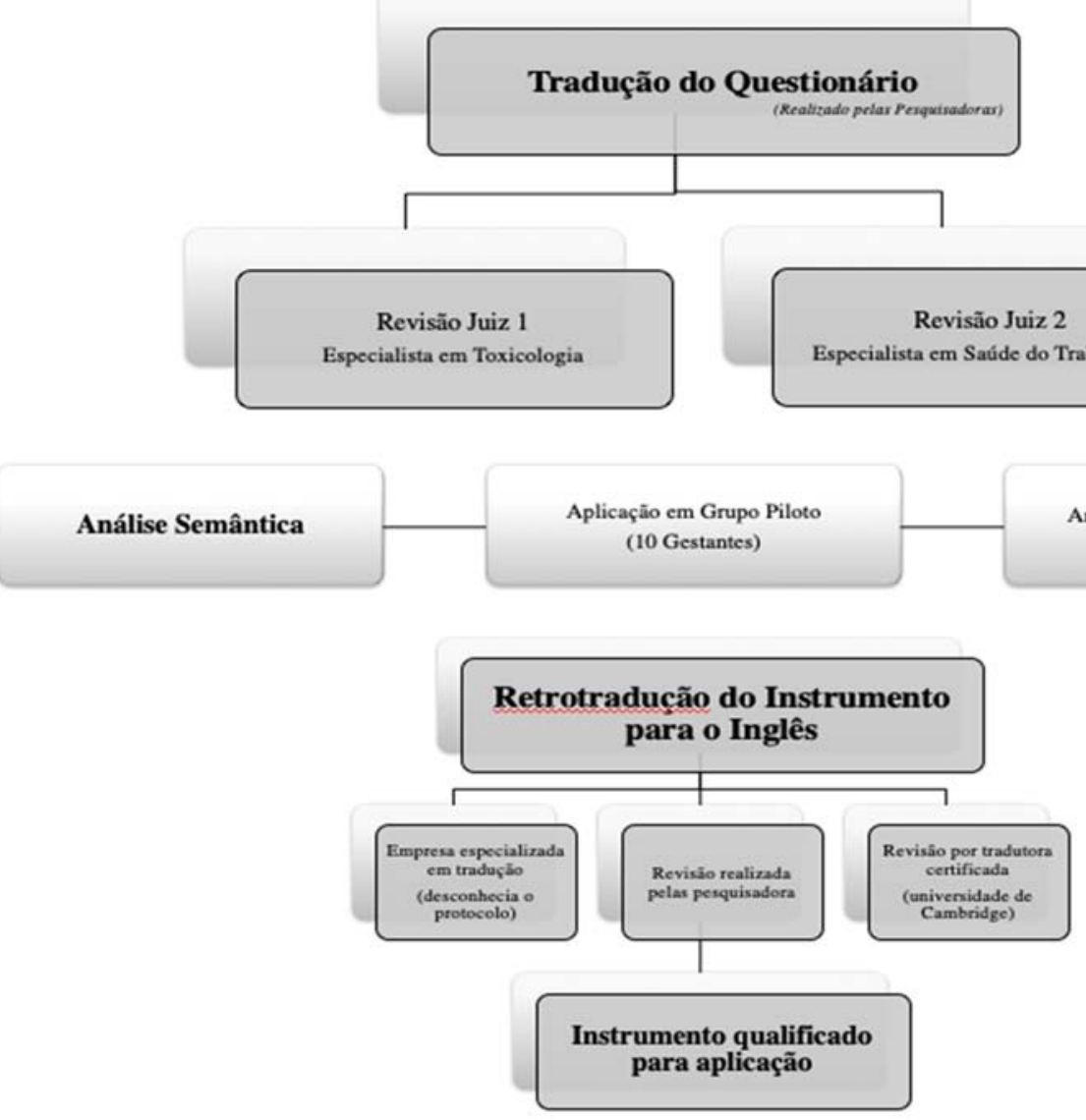

Fonte: Elaborador pelos autores.

O processo de tradução se deu inicialmente por meio da tradução do protocolo por Cassol e Magni (2015), sendo nesse processo, analisado por juízes, sendo um docente especialista em Toxicologia, o que possibilitou a revisão dos termos sobre pesticidas e agrotóxicos e o segundo juiz, uma docente especialista em Saúde do Trabalhador. Após a primeira tradução o instrumento foi aplicado em um grupo de 10 gestantes alfabetizadas, residentes no interior de pequenos municípios do Estado do Paraná, a fim de se obter a análise semântica e adaptação transcultural de termos e adequações de frases, sem que essas alterassem seu sentido/significado e que possibilitassem melhor compreensão por parte das gestantes. Esse grupo de gestantes levantaram a confusão na compreensão de alguns termos como, herbicidas, fungicidas e inseticidas, que levou à substituição destes termos pelo termo agrotóxicos, pois é este termo que os agricultores utilizam. 
O protocolo original em inglês é formatado em subitens que organizam os assuntos abordados. Para melhor entendimento e organização, tanto na aplicação, quanto na análise, as pesquisadoras agruparam as questões do mesmo tema em seções, o que não alterou o conteúdo original, tornando o protocolo traduzido de mais fácil aplicabilidade.

$\mathrm{O}$ instrumento foi aplicado em forma de entrevista, de forma que o pesquisador lia a questão para a gestante e, em seguida, a gestante assinalava a resposta no próprio instrumento. Durante a aplicação foi necessária a adaptação da linguagem e reelaboração de frases que propiciaram uma melhor compreensão das questões por parte das gestantes.

A retrotradução do protocolo para a língua inglesa foi realizada inicialmente por uma empresa especializada em traduções, cujo profissional desconhecia o protocolo, bem como a sua temática, e revisada pelas autoras, sendo por fim encaminhada a uma tradutora com certificação da Universidade de Cambridge, a qual ajustou os erros de discordância e tradução encontrados, qualificando-o para ser aplicado.

Para o estudo preliminar do protocolo traduzido, a população alvo do estudo incluiu gestantes de todos os períodos gestacionais, que trabalhavam na agricultura e que realizavam o acompanhamento pré- natal nos centros de Estratégias da Saúde da Família (ESF) de cidades do interior do Paraná. Ao todo, foram entrevistadas 50 gestantes agricultoras, incluindo as 10 primeiras para a análise semântica do protocolo.

\subsubsection{Descrição do instrumento CAP - Conhecimento, Atitudes e Práticas}

O protocolo KAP - Conhecimento, atitudes e práticas foi organizado em 13 seções, de acordo com a temáticas das perguntas, sendo elas: Seção 1 - Informação ocupacional/ exercício físico; Seção 2 - Características da casa; Seção 3 - Limpeza da casa; Seção 4 - Uso de agrotóxicos; Seção 5 - Conhecimento, atitudes e práticas sobre agrotóxicos; Seção 6 Demografia; Seção 7 - História médica; Seção 8 - História gestacional; Seção 9 - Membros residentes na casa; Seção 10 - Animais domésticos; Seção 11 - Informações sobre hábitos pessoais; Seção 12 - Outras exposições e preocupações; Seção 13 - Questões adicionais.

Para a avaliação das variáveis de Conhecimento. Atitudes e práticas, foram organizas as questões que abrangiam sobre cada variável. Em cada variável foram agrupadas possibilidades de respostas que correspondiam a um tema. Dessa forma, as questões que correspondiam a variável conhecimento envolviam:

a) Conhecimento sobre o prejuízo dos agrotóxicos para a saúde humana $(5.2 ; 5.3)$

b) Conhecimento sobre população de risco (5.4.a até 5.4.b; 5.4.c; 5.4.d; 5.4.e; 5.4.f) 
c) Conhecimento sobre vias de intoxicação (5.5a; 5.5b; 5.5c; $5.5 \mathrm{~d} ; 5.5 \mathrm{e})$

d) Conhecimento dos sintomas de intoxicação (5.9a; 5.9b; 5.9c; 5.9d; 5.9e; 5.9f; 5.9g; $5.9 \mathrm{~h} ; 5.9 \mathrm{i})$

e) Treinamento sobre uso de agrotóxicos (5.10). Nas questões $5.11 \mathrm{a} ; 5.11 \mathrm{~b} ; 5.11 \mathrm{c}, \mathrm{c} 1$ a c4, não foram determinados scores, sendo apenas realizado cruzamento das respostas com o trimestre de gestação.

f) Conhecimento sobre riscos dos agrotóxicos (5.12a; 5.12b;5.12c;5.12d; 5.12e; 5.12f; 5.12g; 5.12h; 5.12i; 5.12j; 5.12k; 5.121; 5.12m; 5.12n; 5.12o; 5.12p)

g) Conhecimento sobre o impacto á saúde (5.13a até 5.13f)

h) Conhecimento sobre outros efeitos dos agrotóxicos (12a e 12b). Nessas questões também não foram determinados scores, sendo apenas realizado cruzamento das respostas com o trimestre de gestação.

Em cada análise dessas, foram feitos cruzamentos com os trimestres de gestação para determinação de um score sobre o item - Atitudes.

a) Atitudes em casa (2.1a e b; $2.2 \mathrm{a}$ e b; 3.a)

b) Uso de vestimenta adequada no trabalho (1.6a até 1.6e)

c) Atitudes prejudiciais para o feto (5.1a até $5.1 \mathrm{~h})$

d) Responsabilidade para uso seguro dos agrotóxicos - ler rotulo das embalagens (5.6)

e) Responsabilidade para uso seguro dos agrotóxicos - reutilização das embalagens

f) Uso de agrotóxicos e pesticidas em casa (4.1 até 4.6 a e b)

Nas questões $5.14 \mathrm{a}$ até $5.14 \mathrm{i} ; 5.15 \mathrm{a}$ até $5.15 \mathrm{f}$, não foram determinados score, sendo apenas realizado o cruzamento das respostas de acordo com o trimestre da gestação. Assim como no item - Atitudes de susceptibilidade aos efeitos na saúde (questões 11a e 11b).

Para determinação do score Práticas, foram analisadas as seguintes questões, obtidas a partir do cruzamento com o trimestre de gestação.

a) Práticas de prevenção (5.8a até $5.8 \mathrm{~g})$.

b) Práticas seguras em casa (9b até $10 . b)$

Algumas questões eram dependentes da resposta da anterior, sendo que, por exemplo, na questão 10.a a resposta do indivíduo fosse não, ele não precisava responder a 10.b. Essas marcações foram sinalizadas no protocolo, com legenda para facilitar o entendimento. 
Ao finalizar esta revisão bibliográfica, conclui-se que os estudos acerca das consequências materno-infantis da exposição aos agrotóxicos ainda são iniciais e carecem de mais dados epidemiológicos e experimentais, porém já alertam sobre um perigo eminente.

Os instrumentos de pesquisa para identificação do conhecimento e práticas da população expostas são ferramentas úteis tanto para identificação, quanto para traçar novas propostas. Traduzir e validar instrumentos já utilizados em outros países, por meio de testes psicométricos, são alternativas seguras a serem utilizadas por pesquisadores. 

3- Objetivos 



\section{OBJETIVOS}

Realizar a validação do Questionário Conhecimentos, Atitudes e Práticas (CAP) em populações de gestantes expostas a agrotóxicos no Estado do Paraná.

\subsection{OBJETIVOS ESPECÍFICOS}

I. Caracterizar a população estudada traçando seu perfil sócio demográfico;

II. Analisar descritivamente as variáveis quantitativas dos construtos de “Conhecimento, Atitudes e Práticas";

III. Determinar a Confiabilidade ou precisão do questionário, analisando os aspectos de Estabilidade, Consistência Interna e Equivalência.

IV. Analisar a Validade de conteúdo do Questionário CAP por meio da avaliação de juízes;

V. Analisar a Validade de critério do Questionário CAP por meio de critério estabelecido;

VI. Analisar a Validade de construto do Questionário CAP por meio da técnica de grupos conhecidos; 



$$
4 \text { - Metodologia }
$$





\section{METODOLOGIA}

Este capítulo apresentará os processos metodológicos deste estudo, que está inserido na linha de pesquisa Saúde Auditiva do Programa de Pós-Graduação em Fonoaudiologia da Faculdade de Odontologia de Bauru - Universidade de São Paulo (FOB/USP).

\subsection{ASPECTOS ÉTICOS}

Este projeto de pesquisa foi aprovado pelo Comitê de Ética em Pesquisa Envolvendo Seres Humanos do Centro Universitário Assis Gurgacz com coparticipação do Comitê de Ética em Pesquisa Envolvendo Seres Humanos da Secretaria de Estado da Saúde do Paraná CEPSH/SESA/HT, sob parecer número 3.422.972 (Anexo A).

Todos os procedimentos das Normas e Diretrizes Regulamentadoras da Pesquisa Envolvendo Seres Humanos - (Res. CNS 466/12) do Conselho Nacional de Ética em Saúde foram cumpridos. Todas as gestantes, que responderam ao questionário receberam os esclarecimentos necessários e assinaram o Termo de Consentimento Livre e Esclarecido (TCLE) (Apêndice A).

\subsection{POPULAÇÃO E AMOSTRA}

A amostra deste estudo foi não probabilística por conveniência, em função da acessibilidade e disponibilidade da população. Ela envolveu todas as gestantes que frequentaram consultas e encontros pré-natais nas Unidades Básicas de Saúde de seus respectivos munícipios, pertencentes aos Regionais selecionados neste estudo, além de gestantes contatadas por meio de busca ativa, no período de Agosto de 2018 e Dezembro de 2019, e que livremente aceitaram participar do estudo.

O campo de coleta selecionado para este estudo compreende a $10^{\text {a }}$ Regional de Saúde com população total superior a 502 mil habitantes, distribuídos em 25 municípios, e a $4^{\text {a }}$ Regional de Saúde que compreende pouco mais de 155 mil habitantes, em 9 municípios (Figura 13 e 14) (SESA/PR, 2020; MPPR, 2020). 
Figura 10 - Ilustração da $10^{\mathrm{a}}$. Regional de Saúde Figura 11 - Ilustração da $4^{\mathrm{a}}$. Regional de Saúde -

- Cascavel
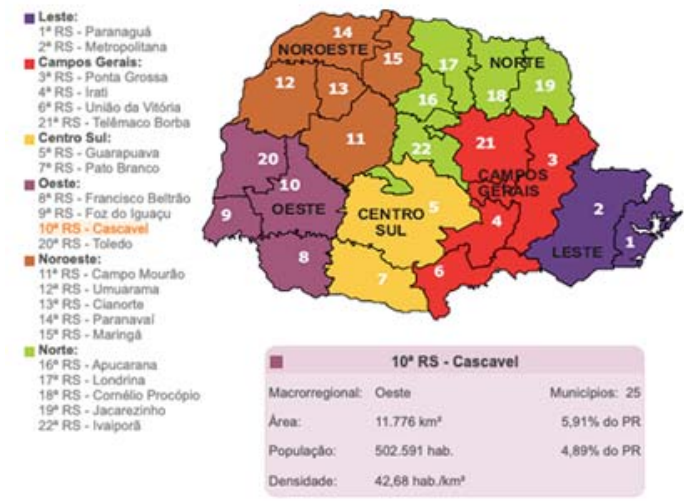

Irati

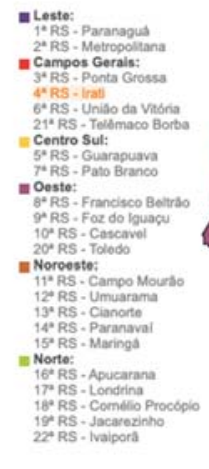

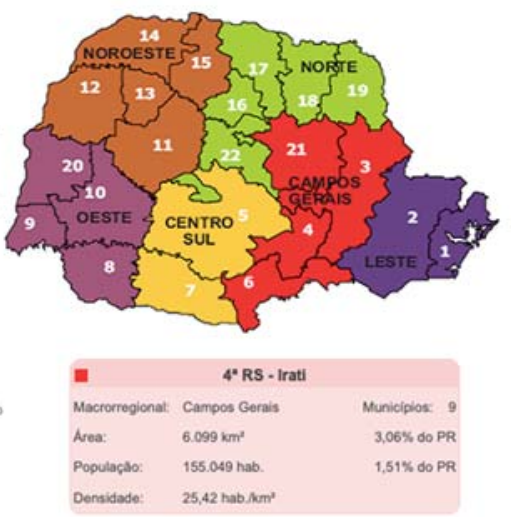

Fonte: SESA/PR - Secretaria de Estado da Saúde do Paraná. Acesso em 27 de abril de 2020.

A população alvo do estudo incluiu 382 gestantes de todos os períodos gestacionais, divididas em dois grupos: Grupo Não Expostas - 62 não expostas a agrotóxicos; Grupo Expostas - 320 expostas a agrotóxicos. As gestantes expostas são mulheres envolvidas direta ou indiretamente com a agricultura, sendo elas expostas aos agrotóxicos, de todos os munícipios que compõem a $4^{\mathrm{a}}$ e $10^{\mathrm{a}}$ Regionais de Saúde do Estado do Paraná, alfabetizadas e com aparente condições emocionais e cognitivas de responder ao questionário sem auxílio da pesquisadora. O Grupo Não Exposta foi composto por gestantes, sem vínculo direto ou indireto com a agricultura. Por se tratar da validação de um instrumento, necessitando de um número significativo de sujeitos, foram recrutados aplicadores do instrumento, que pertencem a Atenção Básica em Saúde (ABS), mediante treinamento sobre os objetivos do instrumento e sua base teórica.

Nesse sentido, após a aprovação do CEPSH/SESA, foi agendado em cada regional uma reunião com todos os secretários de saúde que compõe os regionais, na qual foram esclarecidos os objetivos, procedimentos, riscos e benefícios da pesquisa, e após, foram coletadas as autorizações dos mesmos, que garantia o desenvolvimento da pesquisa em seus respectivos municípios, com o auxílio das ABSs.

$\mathrm{Na}$ sequência, com intermédio das responsáveis pela $\mathrm{ABS}$ das regionais, foram convocadas as enfermeiras responsáveis por cada UBS dos municípios, as Agentes Comunitárias de Saúde (ACS) e demais envolvidos no setor, onde foi realizado um treinamento presencial com todos os presentes para o esclarecimento sobre a pesquisa e aplicação do questionário. $\mathrm{Na}$ ocasião foi orientado sobre a abordagem com as gestantes, o convite para a pesquisa, o assentimento para participação da pesquisa com a coleta da assinatura do TCLE, e 
a aplicação do questionário, tomando o cuidado para não influenciar e/ou induzir a resposta da gestante.

Foram considerados critérios de exclusão as gestantes que não tenham contato direto ou indireto com a agricultura, não alfabetizadas, e/ou com dificuldades de interpretação das questões, que não conseguirem responder ao questionário sem auxílio.

As gestantes expostas aos agrotóxicos foram convidadas a participarem do estudo, após serem previamente informadas sobre o motivo do presente estudo e o tema abordado. Todas que aceitaram responder o protocolo consentiram por meio do TCLE elaborado pelas autoras.

\subsection{CASUÍSTICA}

Segundo dados informados pelo Divisão de Vigilância de Zoonoses e Intoxicações (DVVZI), Centro de Vigilância Ambiental (CEVA), Secretaria de Vigilância da Saúde (SVS) e Secretaria Estadual de Saúde (SES), no período de 2012 a 2016, foram registradas no SINAN NET 4.190 ocorrências de intoxicação por agrotóxicos, sendo que $72,6 \%$ dos casos foram por agrotóxicos de uso agrícola. Os casos de intoxicação por agrotóxicos de uso doméstico representam 24,4\% e os agrotóxicos de uso em saúde pública, 3\%. Dentre as regionais de saúde destaca-se a de Cascavel e Irati, alvo da pesquisa em questão. Desse total, também é possível observar que a faixa etária que mais se intoxica situa-se entre 20 e 49 anos, predominantemente do sexo masculino, que corresponde à faixa etária em idade produtiva, representando $59,5 \%$ do total.

\subsection{APRESENTAÇÃO DO INSTRUMENTO}

O protocolo CAP, originalmente desenvolvido por Lorenz e colaboradores (2012) e traduzido e adaptado para o português brasileiro por Cassol e Magni (2015) aborda sobre o Conhecimento, Atitudes e Práticas de gestantes agricultoras (ANEXO B).

O instrumento inclui questões abrangentes sobre:

- O conhecimento sobre agrotóxicos - informação sobre o treinamento para uso dos produtos, rotas de exposição e riscos envolvidos, efeitos agudos e crônicos sobre a saúde, sintomas da toxicidade e métodos efetivos para prevenir a exposição.

- As atitudes sobre o uso dos agrotóxicos - informação sobre crenças para a responsabilidade de um uso seguro, susceptibilidade para efeitos sobre a saúde, efetividade dos agrotóxicos e razão para uso deles. 
- As práticas para o uso seguro dos agrotóxicos - informação sobre o uso ocupacional e doméstico, uso de equipamento de proteção individual e uso de outras precauções seguras durante e depois da utilização dos agrotóxicos.

\subsection{VALIDAÇÃO DO INSTRUMENTO}

O processo de validação do instrumento ocorre somente após o processo de adaptação cultural, e se justifica em função da necessidade de avaliação das propriedades psicométricas, a confiabilidade e a validade, para verificar se ele retém as características do instrumento original (BEATON et al., 2000). O número de sujeitos em cada teste foi variável (Figura 10). 
Figura 12 - Ilustração do Processo de Validação do Questionário CAP

\section{PROCESSO DE VALIDAÇÃO CAP- Conhecimento, Atitudes e Práticas}

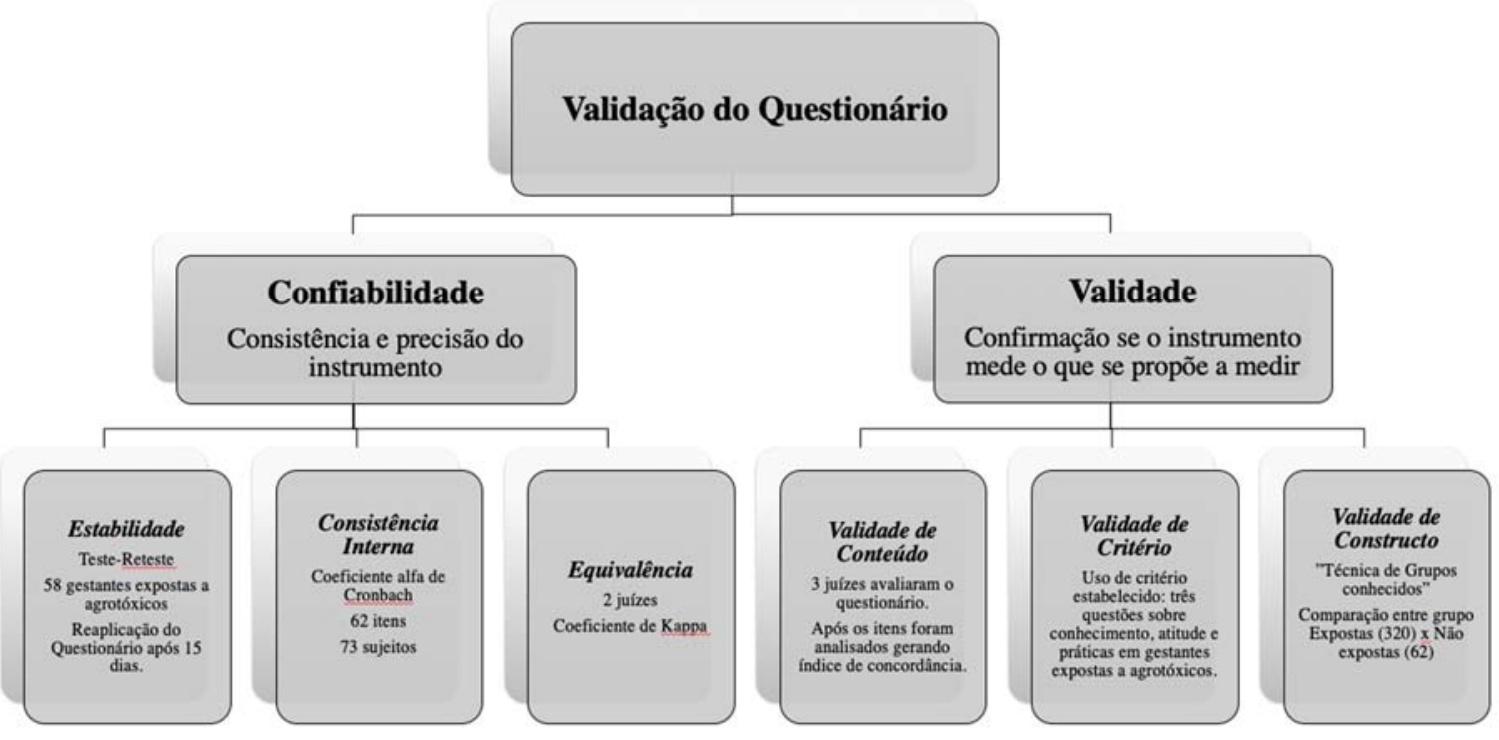

Fonte: Elaborado pelos autores.

\subsubsection{Confiabilidade do Questionário CAP}

Confiabilidade, se refere, a quão estável, consistente e preciso é um instrumento (PASQUALI, 2011). Para essa etapa da pesquisa, foram abordados três critérios segundo descrito na literatura: estabilidade, consistência interna e equivalência.

a) Estabilidade: Para essa etapa conhecida como teste-reteste o instrumento foi aplicado em aproximadamente $20 \%$ da amostra total de gestantes expostas a agrotóxicos, totalizando 58 sujeitos. A reavaliação foi feita no período de sete a quinze dias como preconiza a literatura (KESZEI; NOVAK; STREINER, 2010).

b) Consistência Interna: Para essa medida, obtida por meio do coeficiente alfa de Cronbach considerando 62 itens e 73 sujeitos, devido a apresentação das questões no questionário (CRONBACH, 1951; STREINER; KOTTNER, 2010).

c) Equivalência: Foram selecionados três juízes, sendo que apenas dois juízes responderam, ambos pesquisadores da área de toxicologia, previamente orientados, que preencheram o instrumento, e posteriormente foram analisadas a equivalência de suas respostas por meio do coeficiente de Kappa (SALMOND, 2008; HEALE; TWYCROSS, 2015). 


\subsubsection{Validade do Questionário CAP}

Para a validade, que se refere ao fato de um instrumento medir exatamente o que se propõe a medir, existem três aspectos que correspondem aos objetivos de um teste e se referem à validade de conteúdo, à validade de critério e à validade de construto, sendo esses:

- Validade de conteúdo: para essa avaliação qualitativa dos itens do instrumento, foi selecionado um comitê de especialistas, composto por três juízes, pesquisadores da área de toxicologia que estudam sobre os efeitos dos agrotóxicos no organismo humano. Os mesmos avaliaram questão a questão utilizando a escala a Likert, atribuindo pontuação de 1 a 4 , a cada item apresentado. Foram utilizadas opções mais curtas de análise, sendo elas: $1=$ não claro, 2 = pouco claro, 3 = bastante claro, $4=$ muito claro (WYND; SHMIDT; SCHAEFER, 2003; COLUCI; ALEXANDRE; MILANI, 2015). Após a análise, os itens que pontuaram 1 e 2 foram excluídos do instrumento, e os itens que pontuaram 3 e 4 foram somados e divididos pelo número total de resposta, gerando o índice de concordância entre os especialistas.

- Validade de critério: Por não haver um instrumento padrão-ouro para análise de correlação, optou-se pela validade concorrente, com o uso de um critério estabelecido (ROACH, 2006), sendo ele três perguntas breves, que avaliam o mesmo construto: "1- Você acredita que possui conhecimento adequado sobre os agrotóxicos?; 2 - Você acredita que possui atitudes adequadas frente aos agrotóxicos?; 3 - Você acredita que possui práticas seguras em relação aos agrotóxicos?". As alternativas de respostas eram “sim" e "não". Nessa etapa participaram 244 gestantes expostas a agrotóxicos.

- Validade de construto: refere-se à demonstração de que o instrumento realmente mede aquilo a que se propõe medir (ROACH, 2006; PASQUALI, 2011). Dada as características do questionário, não foi possível a análise da Validade convergente, pois o estudo base não apresenta testes de validação, nem a análise Fatorial pois as questões que compõe o questionário não seguem um padrão. Para elencar evidências necessárias a fim de garantir a validação do construto, foi realizada a técnica de Grupos Conhecidos. Nessa técnica o instrumento foi aplicado nos dois grupos: Grupo Expostas a agrotóxicos composto por 320 gestantes Grupo Não Expostas, com 62 gestantes (ROACH, 2006; POLIT; BECK, 2011). Posteriormente as respostas de ambos os grupos 
foram analisadas e comparadas a fim de verificar respostas diferentes entre eles.

\subsection{APLICAÇÃO DO INSTRUMENTO}

A partir do estudo inicial foi possível verificar que a aplicação do instrumento é simples, pois as questões foram facilmente interpretadas pelas gestantes agricultoras alfabetizadas (CASSOL; MAGNI, 2015). Em função disso e do número extenso de participantes necessários ao estudo de validação, foram recrutados e treinados aplicadores do instrumento, que pertencem a Atenção Básica de Saúde (ABS), os quais deveriam seguir o mesmo padrão de aplicação dos autores. A orientação foi sobre a aplicação do questionário de forma assistida, onde cada item do questionário era lido em voz alta, concomitantemente com o autopreenchimento do questionário pelas participantes. Por gestante, a média de tempo de aplicação foi entre 15 e 20 minutos.

\subsection{ANÁLISE DE DADOS}

Os dados foram analisados de forma descritiva e inferencial. Utilizou-se o software SPSS 25.0.

A análise descritiva das variáveis qualitativas nominais foi realizada por frequência relativa e percentual. A análise descritiva das variáveis quantitativas discretas e contínuas, e qualitativas ordinais foi realizada por do cálculo de medidas de tendência central (média e mediana), variabilidade (desvio padrão) e posição (primeiro quartil e terceiro quartil).

A análise inferencial de associação entre as variáveis foi realizada com os Teste Exato de Fisher e Qui-Quadrado de Pearson. A análise de distribuição das variáveis quantitativas foi realizada com o teste Shapiro-Wilk, e todas obtiveram distribuição não-normal. A análise inferencial das variáveis quantitativas em função de variáveis qualitativas nominais de duas categorias (grupos independentes) foi realizada com o teste de Teste de Mann-Whitney. A análise da concordância entre as variáveis quantitativas foi realizada com o teste de Coeficiente de Correlação Intraclasse, e entre as variáveis qualitativas foi realizada com o teste de Kappa. Para a análise da concordância de variáveis qualitativas nominais utilizou-se o Coeficiente de Concordância de Kappa e para análise da consistência interna do instrumento utilizou o Alfa de Cronbach. 

5- Resultados 



\section{RESULTADOS}

\subsection{CARACTERIZAÇÃO DA AMOSTRA}

A pesquisa foi realizada entre Agosto de 2018 e Dezembro de 2019. A amostra do presente estudo foi composta por 382 gestantes, divididas em dois grupos: Grupo Não Expostas - 62 não expostas a agrotóxicos; Grupo Expostas - 320 expostas a agrotóxicos. Os grupos e número de participantes em cada etapa do estudo de validação foi variável. A $10^{\mathrm{a}}$ Regional de Saúde, que abrange a região Oeste do Estado do Paraná teve participação maior ( $\mathrm{n}=320 ; 84 \%)$ que a $4^{\text {a }}$ Regional de Saúde, correspondente a região Sudeste do estado (n=62;16\%).

Considerando apenas o Grupo Expostas, a idade média das participantes foi de 26 anos e seis meses, e os trimestres de gestação mostram uma maior participação de gestantes no $3^{\circ}$ trimestre $(n=126 ; 39,4 \%)$. A maioria das participantes é de nacionalidade brasileira $(n=310$; $96,9 \%$ ) e o grau de escolaridade mais frequente foi o de ensino médio completo ( $n=93 ; 29,1 \%$ ), sendo que apenas $17,8 \%$ do total das participantes encontravam-se estudando no momento da pesquisa.

A renda familiar de $31,6 \%$ das participantes é de menos de um salário mínimo (R\$ $975,00)^{12}$, e de $44,7 \%$ entre um e dois salários. Sobre as gestações anteriores, observou-se uma média de duas gestações.

Referente a ocupação das Gestantes Expostas, 54,38\% (n=174) relatam trabalhar desde que ficaram grávidas, enquanto que 45,63\% $(n=146)$ negam ter trabalhado. Das que assinalaram ter trabalhado, quando questionadas se o trabalho envolve a agricultura, 25,63\% $(\mathrm{n}=82)$ responderam que $\operatorname{sim}$, e 28,75\% (n=92) não; outras $146(45,63 \%)$ gestantes não responderam essa questão, como um critério do questionário, uma vez que assinalaram não estar trabalhando na gravidez. Quando questionadas se atualmente trabalham, 60,94\% $(\mathrm{n}=195)$ afirmaram, e $39,06 \%(\mathrm{n}=125)$ negaram; $72,19 \%(\mathrm{n}=231)$ relatam que há um ano atrás estavam trabalhando, contra 27,81\% $(n=89)$ que não. Relativo a quando parou de trabalhar, $6,25 \%(n=20)$ relatam que pararam antes de saber da gestação, 32,19\% (n=103) após saber da gravidez, e outras 197 $(61,56 \%)$ afirmam não ter interrompido o trabalho.

\footnotetext{
12 Valores referentes a média do salário Mínimo Brasileiro vigente entre 2018 e 2019 segundo o Diário Oficial da União. Disponível em: http://www.in.gov.br/materia//asset_publisher/Kujrw0TZC2Mb/content/id/57510734/dolesp-2019-01-01-decreto-n-9-661-de-1-de-janeiro-de2019-57510684. Acesso em março de 2020.
} 
Sobre o planejamento ocupacional, $102(31,88 \%)$ relatam que irão parar de trabalhar apenas quando o médico determinar ou quando não conseguir mais trabalhar, enquanto que 97 $(30,31 \%)$ pretendem trabalhar até dar à luz, e outras $120(37,50 \%)$ gestantes ainda não sabem se pararão. Após dar à luz, $251(78,44 \%)$ das gestantes pretendem trabalhar, 16,56\% (n=53) não, e 5\% (n=16) não sabe ainda. Sobre o período de retorno ao trabalho, 35,63\% (n=114) acredita retornar entre 3 meses após dar à luz, 9,38\% $(n=30) 3$ e 6 meses após dar à luz, 7,5\% $(n=24) 6$ meses após dar à luz, e 47,5\% $(n=152)$ ainda não tem conhecimento.

A Tabela 5 mostra a caracterização do local onde vivem, ocupação das atividades e uso de agrotóxicos em gestantes do Grupo Expostas. É importante relatar que, segundo o questionário, se a gestante assinalasse negativamente a algumas questões, como por exemplo, ter trabalhado durante o período gestacional, ter aplicado agrotóxicos, dentre outras, automaticamente, ela deixava de responder as questões na sequência, pois as mesmas já não faziam sentido; nesse caso, é apresentado na tabela como "Dados ausentes", sendo que quando a entrevistada não respondia, por qualquer outro motivo, é denominado "Sem resposta". 
Tabela 5 - Análise descritiva das variáveis qualitativas de caracterização do local onde vive, ocupação das atividades e uso de agrotóxicos em gestantes do Grupo Expostas.

\begin{tabular}{|c|c|c|}
\hline Variável e categorias & $\mathrm{n}$ & $\%$ \\
\hline \multicolumn{3}{|c|}{ Região que mora atualmente (agrícola ou não) } \\
\hline Eu vivo em uma área agrícola & 204 & 63,75 \\
\hline Eu vivo próximo a uma área agrícola & 30 & 9,38 \\
\hline Eu não vivo próximo a uma área agrícola & 82 & 25,63 \\
\hline Sem resposta* & 4 & 1,25 \\
\hline \multicolumn{3}{|l|}{ Tempo que vive na região } \\
\hline Desde que nasceu & 108 & 33,75 \\
\hline$<5$ anos & 88 & 27,50 \\
\hline $5-10$ anos & 19 & 5,94 \\
\hline 10-20 anos & 90 & 28,13 \\
\hline 20-30 anos & 3 & 0,94 \\
\hline$>30$ anos & 1 & 0,31 \\
\hline Sem resposta* & 11 & 3,44 \\
\hline \multicolumn{3}{|c|}{$\begin{array}{c}\text { Durante a gestação, no emprego, realizou manutenção de grande área } \\
\text { agrícola ou vegetação }\end{array}$} \\
\hline Sim & 13 & 4,06 \\
\hline Não & 78 & 24,38 \\
\hline Dados ausentes** & 229 & 71,56 \\
\hline \multicolumn{3}{|c|}{$\begin{array}{c}\text { Durante a gestação, no emprego, fez controle de cupins e outras } \\
\text { pragas em casa ou edifícios }\end{array}$} \\
\hline Sim & 23 & 7,19 \\
\hline Não & 68 & 21,25 \\
\hline Dados ausentes** & 229 & 71,56 \\
\hline \multicolumn{3}{|c|}{$\begin{array}{c}\text { Durante a gestação, no emprego, fez trabalho em canavial ou outras } \\
\text { plantas alimentícias onde manuseava frutas ou vegetais }\end{array}$} \\
\hline Sim & 39 & 12,19 \\
\hline Não & 53 & 16,56 \\
\hline Dados ausentes** & 228 & 71,25 \\
\hline \multicolumn{3}{|c|}{ Agrotóxicos são usados próximo a casa (exposição a agrotóxicos) } \\
\hline $\operatorname{Sim}$ & 193 & 60,31 \\
\hline Não & 111 & 34,69 \\
\hline Não sei & 16 & 5,00 \\
\hline \multicolumn{3}{|c|}{ Aplicou ou não agrotóxicos } \\
\hline Sim & 4 & 1,25 \\
\hline Não & 187 & 58,44 \\
\hline Não sei & 26 & 8,28 \\
\hline Dados ausentes** & 103 & 32,19 \\
\hline
\end{tabular}

\section{Análise descritiva}

Legenda: $\mathrm{n}=$ frequência relativa; $\%=$ frequência percentual

* Entrevistada não respondeu a questão.

** Dados não respondidos pelas gestantes, segundo critérios do questionário. 
Acerca dos recursos médicos utilizados para realização do pré-natal, o destaque foi o SUS, representado por mais de $70 \%$ das usuárias, seguido da saúde suplementar com $23 \%$; nessa questão, a gestante poderia assinalar mais de uma alternativa, caso utilizasse mais de um serviço (Figura 11).

Figura 13 - Benefício médico utilizado para realizar o pré-natal.

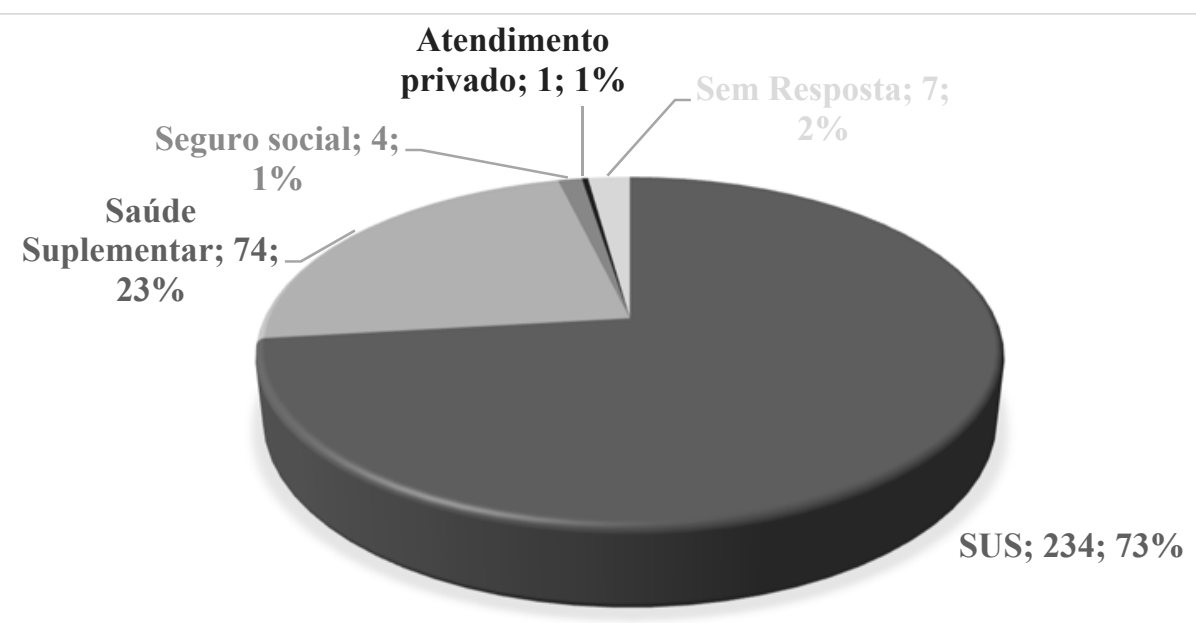

Análise descritiva

Legenda: $n=$ frequência relativa; \%=frequência percentual

Referente a quantas consultas participou no pré-natal a média foi de 2,51 vezes, e sobre o mês da primeira visita ao programa foi de 2,16 meses de gestação.

\subsection{ANÁLISE DO CONHECIMENTO, DAS ATITUDES E DAS PRÁTICAS}

Caracteriza-se como "Conhecimento" a informação sobre o treinamento para uso dos pesticidas, rotas de exposição e riscos envolvidos, efeitos agudos e crônicos sobre a saúde, sintomas da toxicidade e métodos efetivos para prevenir a exposição. A análise foi feita a partir de um score determinado com base na \% de questões respondidas corretamente.

Considerando que um score de "Conhecimento" maior que a média indica que a gestante possui alto grau de conhecimento, a análise da Tabela 6 permite verificar um nível de conhecimento significativo das gestantes sobre todos os itens relacionados. A maioria das entrevistadas concorda sobre os danos dos agrotóxicos afetarem diferentes populações, independentemente de serem agricultores ou não, bem como, reconhece as principais vias de intoxicação e seus sintomas. Nos itens referentes ao conhecimento sobre o prejuízo dos 
agrotóxicos para a saúde humana e sobre riscos dos agrotóxicos a média apresentou-se mais baixa, mesmo sendo acima da média.

Tabela 6 - Análise descritiva das variáveis quantitativas contínuas do construto de "Conhecimento" do Questionário CAP em gestantes do Grupo Expostas

\begin{tabular}{llllll}
\hline Variável & Média & DP & Q25 & Mediana & Q75 \\
\hline $\begin{array}{l}\text { Conhecimento sobre o prejuízo dos agrotóxicos } \\
\text { para a saúde humana }\end{array}$ & 58,91 & 24,22 & 50,00 & 50,00 & 50,00 \\
Conhecimento sobre população de risco & 89,84 & 23,79 & 83,33 & 100,00 & 100,00 \\
Conhecimento sobre vias de intoxicação & 71,81 & 27,05 & 60,00 & 80,00 & 80,00 \\
Conhecimento dos sintomas de intoxicação & 74,69 & 26,12 & 66,67 & 77,78 & 100,00 \\
Conhecimento sobre riscos dos agrotóxicos & 59,65 & 22,90 & 43,75 & 68,75 & 81,25 \\
Conhecimento sobre o impacto à saúde & 60,42 & 26,44 & 50,00 & 66,67 & 83,33 \\
\hline
\end{tabular}

Análise descritiva

Legenda: n=frequência relativa; DP=desvio padrão; Q25=primeiro quartil; Q75=terceiro quartil

Quando questionadas sobre o conhecimento de outros efeitos que os agrotóxicos podem causar, 63,75\% $(\mathrm{n}=204)$ nega conhecer, $12,5 \%(\mathrm{n}=40)$ afirma conhecer, e 23,75\% $(\mathrm{n}=76)$ relata não ter conhecimento.

A maioria das gestantes entrevistadas não receberam treinamento sobre os agrotóxicos $(\mathrm{n}=300 ; 93,75 \%)$, e apenas 20 gestantes $(6,25 \%)$ que o receberam, relatam que o mesmo foi realizado por intermédio das empresas fornecedoras dos produtos, empresas/cooperativas vinculadas ao seu emprego, e sindicatos, à cerca de 2 anos. Apenas essas mulheres responderam as questões sobre os tópicos discutidos no treinamento (Figura 12) 
Figura 14 - Tópicos discutidos no treinamento sobre agrotóxicos

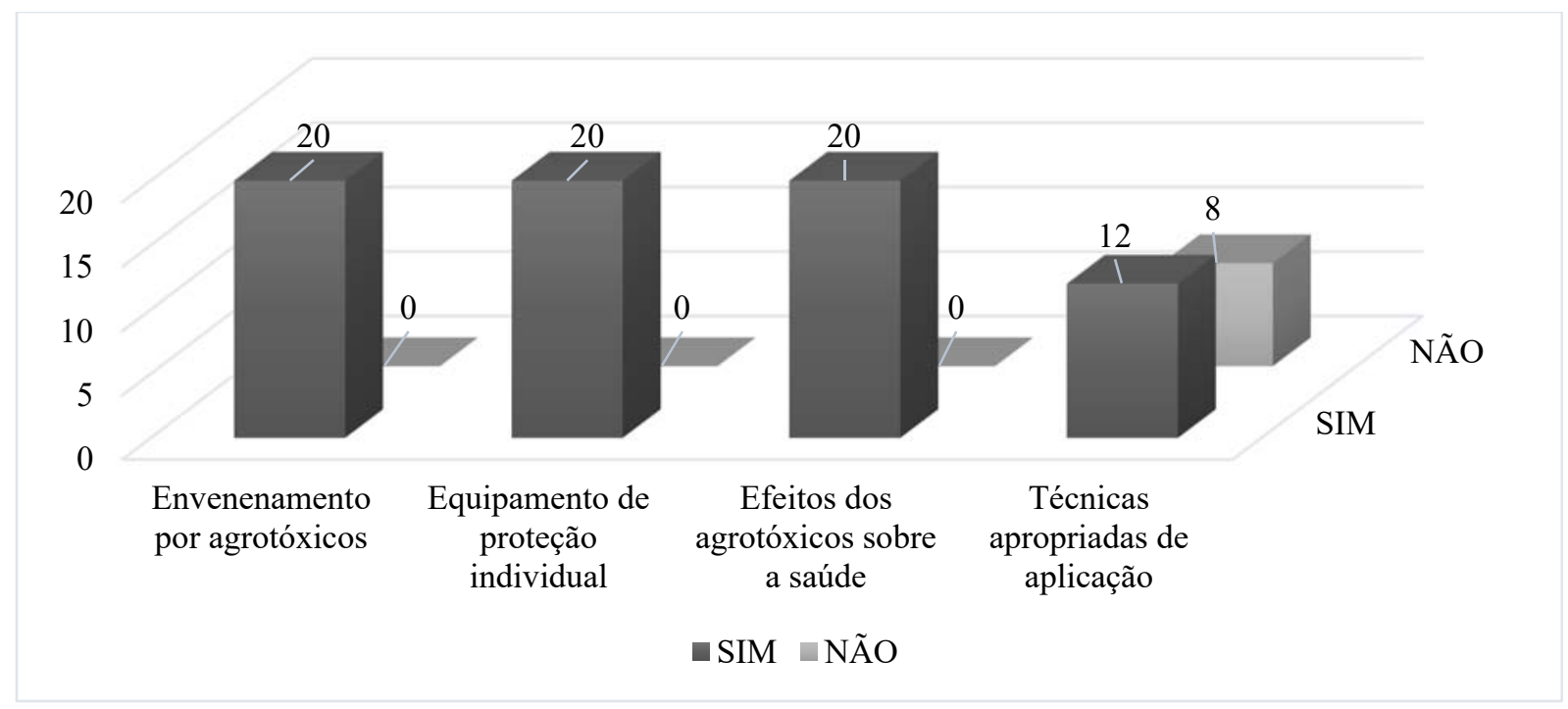

Análise descritiva

Legenda: $\mathrm{n}=$ frequência relativa; \% $\%$ frequência percentual

A análise sobre as "Atitudes" foi obtida com base na média de acertos das questões respondidas que seriam favoráveis a atitudes de responsabilidade para um uso seguro do agrotóxico, à susceptibilidade para efeitos na saúde, às razões para usar o agrotóxico. Nessa análise é possível verificar que a média de acertos foi baixa nos itens "Uso de vestimenta adequada no trabalho", "Uso de agrotóxicos e cuidados", "Motivos para o uso de agrotóxicos em casa" e "Motivos para uso de agrotóxicos no trabalho" (Tabela 7).

Tabela 7- Análise descritiva das variáveis quantitativas contínuas do construto de "Atitudes” do Questionário CAP em gestantes do Grupo Expostas

\begin{tabular}{cccccc}
\hline Variável & Média & DP & Q25 & Mediana & Q75 \\
\hline Atitudes em casa & 63,63 & 12,54 & 60,00 & 60,00 & 60,00 \\
Uso de vestimenta adequada no trabalho & 24,40 & 24,18 & 0,00 & 20,00 & 40,00 \\
Atitudes prejudiciais para o feto & 82,46 & 21,45 & 87,50 & 87,50 & 100,00 \\
Responsabilidade para uso seguro dos agrotóxicos, & 94,06 & 23,67 & 100,00 & 100,00 & 100,00 \\
ler rótulo das embalagens & 74,06 & 43,90 & 0,00 & 100,00 & 100,00 \\
Responsabilidade para uso seguro dos agrotóxicos, \\
reutilização das embalagens & 38,82 & 13,38 & 28,57 & 42,86 & 42,86 \\
Uso de agrotóxicos e cuidados & 31,23 & 20,59 & 11,11 & 33,33 & 44,44 \\
Motivos para uso de agrotóxicos em casa & 15,54 & 14,76 & 0,00 & 16,67 & 29,17 \\
\hline
\end{tabular}

Análise descritiva

Legenda: $\mathrm{n}=$ frequência relativa; $\mathrm{DP}=$ desvio padrão; Q25=primeiro quartil; Q75=terceiro quartil 
Referente a "Atitudes tomadas em casa", como cuidados com a lavagem de frutas e verduras antes de comer, "Atitudes prejudiciais para o feto", "Responsabilidade para uso seguro dos agrotóxicos, ler rótulo das embalagens" bem como "Responsabilidade para uso seguro dos agrotóxicos, reutilização das embalagens" foi caracterizada como atitudes seguras e que demonstra responsabilidade quanto ao uso de agrotóxicos por grande parte das gestantes.

As "Práticas" para o uso seguro dos agrotóxicos referem-se à informação sobre o uso ocupacional e doméstico, uso de equipamento de proteção individual e uso de outras precauções seguras durante e depois da utilização dos agrotóxicos (Tabela 8). As práticas de precaução, em casa e no trabalho, como formas efetivas de prevenir a exposição a agrotóxicos, refere-se ao uso de equipamento de proteção e os resultados revelam práticas seguras nos três trimestres de gestação. Nessa análise, apenas o item "Práticas referentes a animais domésticos" obteve média de acertos baixa.

Tabela 8 - Análise descritiva das variáveis quantitativas contínuas do construto de práticas do Questionário CAP em gestantes do Grupo Expostas

\begin{tabular}{cccccc}
\hline Variável & Média & DP & Q25 & Mediana & Q75 \\
\hline Práticas de precaução & 89,38 & 14,60 & 85,71 & 85,71 & 100,00 \\
Práticas seguras em casa & 78,30 & 22,31 & 60,00 & 80,00 & 100,00 \\
Práticas referentes a animais domésticos & 42,50 & 20,34 & 50,00 & 50,00 & 50,00 \\
\hline
\end{tabular}

Análise descritiva

Legenda: n=frequência relativa; DP=desvio padrão; Q25=primeiro quartil; Q75=terceiro quartil

\subsection{RESULTADOS PARA CONFIABILIDADE}

A confiabilidade, que representa o quão estável, consistente ou preciso é o instrumento, é um dos critérios principais de qualidade de um instrumento e aborda a capacidade em reproduzir um resultado de forma consistente no tempo e no espaço, ou a partir de observadores diferentes, indicando aspectos sobre coerência, precisão, estabilidade, equivalência e homogeneidade. Para essa avaliação, foram realizados os testes de estabilidade, consistência interna e equivalência de uma medida (MARTINS, 2006).

\subsubsection{Confiabilidade quanto a Estabilidade}

Para a análise da confiabilidade quanto a estabilidade o instrumento foi aplicado duas vezes com intervalo máximo de 15 dias (KESZEI; NOVAK; STREINER, 2010). Foi utilizado como medição, o coeficiente de correlação interclasse (intraclass correlation coeficiente ICC), no qual valores mínimos de 0,70 são considerados satisfatórios (TERWEE, et al., 2007). 
A Tabela 9 mostra que apenas para o domínio "responsabilidade para uso seguro dos agrotóxicos, ler rótulo das embalagens" o valor do CCI foi negativo, e para o domínio "Uso de vestimenta adequada no trabalho" o valor foi inferior a 0,7 , sendo que para todos os demais o valor foi superior a 0,7 .

Tabela 9 - Confiabilidade teste-reteste para as variáveis quantitativas contínuas dos construtos de conhecimento, atitudes e práticas do Questionário CAP em gestantes do Grupo Expostas

\begin{tabular}{ccc}
\hline & $\begin{array}{c}\text { Correlação } \\
\text { intraclasse }\end{array}$ & p-valor \\
& & \\
\hline Conhecimento sobre o prejuízo dos agrotóxicos & 1,000 & $<0,001^{*}$ \\
para a saúde humana & 0,868 & $<0,001^{*}$ \\
Conhecimento sobre população de risco & 0,898 & $<0,001^{*}$ \\
Conhecimento sobre vias de intoxicação & 0,999 & $<0,001^{*}$ \\
Conhecimento dos sintomas de intoxicação & 1,000 & $<0,001^{*}$ \\
Conhecimento sobre riscos dos agrotóxicos & 1,000 & $<0,001^{*}$ \\
Conhecimento sobre o impacto à saúde & 0,921 & $<0,001^{*}$ \\
Atitudes em casa & 0,643 & $0,027^{*}$ \\
\hline Uso de vestimenta adequada no trabalho & 0,998 & $<0,001^{*}$ \\
Atitudes prejudiciais para o feto & $-0,091$ & $<0,001^{*}$ \\
Responsabilidade para uso seguro dos agrotóxicos, & & \\
ler rótulo das embalagens & 0,751 & $<0,001^{*}$ \\
\hline Responsabilidade para uso seguro dos agrotóxicos, & & $<0,001^{*}$ \\
reutilização das embalagens & 0,944 & $<0,001^{*}$ \\
Uso de agrotóxicos e cuidados & 1,000 & $<0,001^{*}$ \\
\hline Motivos para uso de agrotóxicos em casa & 0,859 & $<0,001^{*}$ \\
Motivos para uso de agrotóxicos no trabalho & 1,000 & $<0,001^{*}$ \\
Práticas de precaução & 1,000 & $<0,001^{*}$ \\
Práticas seguras em casa & 1,000 & \\
Práticas referentes a animais domésticos & & \\
\hline
\end{tabular}

Coeficiente de Correlação Intraclasse

A Tabela 10 mostra que todos os domínios, ou questões dos domínios apresentaram Kappa $1,0$. 
Tabela 10 - Confiabilidade teste-reteste para as variáveis qualitativas nominais do construto de conhecimento do Questionário CAP em gestantes do Grupo Expostas

\begin{tabular}{ccc}
\hline & Kappa & p-valor \\
\hline Treinamento sobre uso de agrotóxicos 5.10 & 1,000 & $<0,001^{*}$ \\
Treinamento sobre uso de agrotóxicos 5.11c1 & 1,000 & $<0,001^{*}$ \\
Treinamento sobre uso de agrotóxicos 5.11c2 & 1,000 & $<0,001^{*}$ \\
Treinamento sobre uso de agrotóxicos 5.11c3 & 1,000 & $<0,001^{*}$ \\
Treinamento sobre uso de agrotóxicos 5.11c4 & 1,000 & $<0,001^{*}$ \\
Treinamento sobre uso de agrotóxicos 5.11c5 & 1,000 & $<0,001^{*}$ \\
Conhecimento sobre outros efeitos dos agrotóxicos & 1,000 & $<0,001^{*}$
\end{tabular}

Kappa

\subsubsection{Confiabilidade quanto a Consistência Interna}

Para a análise de confiabilidade quanto à consistência interna foram considerados os itens que todos os participantes deveriam preencher, independentemente das respostas das demais questões. Para isso foi calculada a correlação de item total corrigida, o valor do coeficiente Alfa de Cronbach para o instrumento no formato atual, e o valor do Alfa de Cronbach para o instrumento se o item fosse excluído. O Alfa de Cronbach do instrumento considerando 62 itens e 73 sujeitos foi de 0,906. Os resultados do teste mostram que as correlações corrigidas do item-total foram de fortes a fracas, porém, não houve necessidade de excluir nenhum item, considerando-se que as exclusões afetariam muito pouco a consistência interna do instrumento (Apêndice 1 - Análise da consistência interna).

\subsubsection{Confiabilidade quanto a Equivalência}

A análise da confiabilidade para equivalência foi feita com base na análise do coeficiente de concordância entre as respostas de dois juízes para o Questionário CAP. Considerando-se que se tratavam de variáveis qualitativas nominais, utilizou-se o Coeficiente de Concordância de Kappa, que trata-se de uma medida de concordância entre os avaliadores e assume valor máximo igual a 1,00, ou seja, quanto maior o valor de Kappa, maior a concordância entre os observadores. A Tabela 11 mostra um valor de Kappa de 0,448 o que indica a inexistência de concordância. 
Tabela 11 - Análise do coeficiente de concordância do Questionário CAP

\begin{tabular}{cccc}
\hline & & Valor & p-valor \\
\hline Medida de concordância & Kappa & 0,448 & $<0,001^{*}$
\end{tabular}

Coeficiente de Concordância de Kappa

\subsection{RESULTADOS PARA VALIDADE}

Essa medida refere-se ao fato do instrumento medir exatamente o que se propõe a medir, e para isso foram analisados três tipos principais de validade: validade de conteúdo, validade de critério e validade de constructo.

\subsubsection{Validade de Conteúdo}

Para analisar a validade de conteúdo, que refere-se ao grau em que o conteúdo de um instrumento reflete adequadamente o construto que está sendo medido, utilizou-se o Índice de Validade de Conteúdo (POLIT, 2015). Três juízes analisaram cada questão atribuindo uma pontuação de 1 a 4, em que: 1 = item não claro; 2 = item pouco claro; 3 = item bastante claro; e 4 = item muito claro (COLUCI; ALEXANDRE; MILANI, 2015). Foi contabilizada a contagem do número de questões com notas três e quatro, e total da contagem foi dividido pelo número total de questões avaliadas. $\mathrm{O}$ cálculo foi realizado para cada juiz individualmente, e para o total de juízes. A Tabela 12 mostra que o IVC foi entre 0,94 e 0,97 para os juízes individuais, e de 0,96 para o total de juízes, o que demonstrou concordância aceitável entre os membros do comitê de especialistas (POLIT; BECK, 2006).

Tabela 12 - Análise do Índice de Validade de Conteúdo do Questionário CAP

\begin{tabular}{cccc}
\hline Juíz & $\mathrm{n}(3$ e 4) & n (total) & IVC \\
\hline Juíz 1 & 148 & 154 & 0,96 \\
Juíz 2 & 145 & 154 & 0,94 \\
Juíz 3 & 150 & 154 & 0,97 \\
Total & 443 & 462 & 0,96 \\
\hline
\end{tabular}

\subsubsection{Validade de Critério}

Para a análise da validade de critério, que consiste na relação entre pontuações de um determinado instrumento e algum critério externo (KIMBERLIN; WINTERSTEIN, 2008), os escores dos domínios de cada construto foram comparados entre dois grupos independentes constituídos a partir das respostas para questões que analisam o mesmo construto. Para isso, os 
participantes foram orientados a responder "sim" ou "não" para as perguntas: a) "Você acredita que tem conhecimento adequado sobre os efeitos dos produtos agrotóxicos?"; b) "Você acredita que tem atitudes adequadas frente aos agrotóxicos?", e c) "Você acredita que possui práticas seguras sobre os agrotóxicos?”. Devido a distribuição não-normal dos escores foi utilizado o teste não-paramétrico para comparação de dois grupos independentes Teste de Mann-Whitney. Além disso, para as variáveis qualitativas nominais de domínios ou perguntas do construto conhecimento, foi realizada associação entre as categorias de respostas as questões, e as categorias de resposta aos domínios ou perguntas do construto (Tabela 13, 14 e 15). Observase nessa análise que não houve diferença ou associação entre as questões critério, e os domínios ou perguntas do questionário CAP. 
Tabela 13 - Comparação dos escores das perguntas do construto "Conhecimento" do Questionário CAP em função dos grupos independentes constituídos a partir das respostas a uma pergunta que avalia o mesmo construto em agricultoras do Grupo Expostas

\begin{tabular}{|c|c|c|c|c|c|c|c|}
\hline Variável & $\begin{array}{l}\text { Você acredita que tem conhecimento adequado } \\
\text { sobre os efeitos dos produtos agrotóxicos? }\end{array}$ & Média & DP & Q25 & Mediana & Q75 & p-valor \\
\hline \multirow{2}{*}{$\begin{array}{l}\text { Conhecimento sobre o prejuízo dos } \\
\text { agrotóxicos para a saúde humana }\end{array}$} & Sim & 60,19 & 24,42 & 50,00 & 50,00 & 50,00 & \multirow{2}{*}{0,577} \\
\hline & Não & 58,33 & 23,07 & 50,00 & 50,00 & 50,00 & \\
\hline \multirow{2}{*}{ Conhecimento sobre população de risco } & Sim & 89,51 & 23,74 & 83,33 & 100,00 & 100,00 & \multirow{2}{*}{0,524} \\
\hline & Não & 91,27 & 22,18 & 100,00 & 100,00 & 100,00 & \\
\hline \multirow{2}{*}{ Conhecimento sobre vias de intoxicação } & Sim & 70,56 & 23,44 & 60,00 & 80,00 & 80,00 & \multirow{2}{*}{0,054} \\
\hline & Não & 72,38 & 30,72 & 60,00 & 80,00 & 100,00 & \\
\hline \multirow{2}{*}{ Conhecimento dos sintomas de intoxicação } & Sim & 75,10 & 27,30 & 55,56 & 83,33 & 100,00 & \multirow{2}{*}{0,734} \\
\hline & Não & 76,98 & 24,92 & 66,67 & 77,78 & 100,00 & \\
\hline \multirow{2}{*}{ Conhecimento sobre riscos dos agrotóxicos } & Sim & 58,91 & 21,31 & 43,75 & 56,25 & 81,25 & \multirow{2}{*}{0,160} \\
\hline & Não & 62,20 & 25,99 & 43,75 & 68,75 & 81,25 & \\
\hline \multirow{2}{*}{ Conhecimento sobre o impacto à saúde } & Sim & 60,49 & 26,63 & 50,00 & 66,67 & 83,33 & \multirow{2}{*}{0,964} \\
\hline & Não & 60,32 & 27,85 & 50,00 & 66,67 & 83,33 & \\
\hline
\end{tabular}

Teste de Mann-Whitney

Legenda: $n=$ frequência relativa; $\mathrm{DP}=$ desvio padrão; Q25=primeiro quartil; Q75=terceiro quartil 
Tabela 14 - Comparação dos escores das perguntas do construto “Atitudes” do Questionário CAP em função dos grupos independentes constituídos a partir das respostas a uma pergunta que avalia o mesmo construto em agricultoras do Grupo Expostas

\begin{tabular}{|c|c|c|c|c|c|c|c|}
\hline Variável & $\begin{array}{l}\text { Você acredita que tem atitudes } \\
\text { adequadas frente aos agrotóxicos? }\end{array}$ & Média & DP & Q25 & Mediana & Q75 & p-valor \\
\hline \multirow{2}{*}{ Atitudes em casa } & Sim & 64,08 & 12,83 & 60,00 & 60,00 & 60,00 & \multirow{2}{*}{0,567} \\
\hline & Não & 62,77 & 11,21 & 60,00 & 60,00 & 60,00 & \\
\hline \multirow{2}{*}{ Uso de vestimenta adequada no trabalho } & Sim & 29,52 & 30,08 & 0,00 & 20,00 & 60,00 & \multirow{2}{*}{0,176} \\
\hline & Não & 14,17 & 17,17 & 0,00 & 20,00 & 20,00 & \\
\hline \multirow{2}{*}{ Atitudes prejudiciais para o feto } & Sim & 81,12 & 23,42 & 75,00 & 87,50 & 100,00 & \multirow{2}{*}{0,849} \\
\hline & Não & 82,98 & 19,82 & 84,38 & 87,50 & 100,00 & \\
\hline \multirow{2}{*}{$\begin{array}{l}\text { Responsabilidade para uso seguro dos agrotóxicos, } \\
\text { ler rótulo das embalagens }\end{array}$} & Sim & 94,90 & 22,12 & 100,00 & 100,00 & 100,00 & \multirow{2}{*}{0,503} \\
\hline & Não & 92,55 & 26,39 & 100,00 & 100,00 & 100,00 & \\
\hline \multirow{2}{*}{$\begin{array}{l}\text { Responsabilidade para uso seguro dos agrotóxicos, } \\
\text { reutilização das embalagens }\end{array}$} & Sim & 72,45 & 44,91 & 0,00 & 100,00 & 100,00 & \multirow{2}{*}{0,616} \\
\hline & Não & 69,15 & 46,44 & 0,00 & 100,00 & 100,00 & \\
\hline \multirow{2}{*}{ Uso de agrotóxicos e cuidados } & Sim & 36,73 & 13,75 & 28,57 & 42,86 & 42,86 & \multirow{2}{*}{0,591} \\
\hline & Não & 38,26 & 13,11 & 28,57 & 42,86 & 42,86 & \\
\hline \multirow{2}{*}{ Motivos para uso de agrotóxicos em casa } & Sim & 32,16 & 22,58 & 11,11 & 33,33 & 44,44 & \multirow{2}{*}{0,670} \\
\hline & Não & 32,79 & 19,50 & 11,11 & 33,33 & 44,44 & \\
\hline \multirow{2}{*}{ Motivos para uso de agrotóxicos no trabalho } & Sim & 14,29 & 15,73 & 0,00 & 16,67 & 33,33 & \multirow{2}{*}{0,489} \\
\hline & Não & 16,29 & 15,03 & 0,00 & 16,67 & 29,17 & \\
\hline
\end{tabular}

Teste de Mann-Whitney

Legenda: $n=$ frequência relativa; $\mathrm{DP}=$ desvio padrão; $\mathrm{Q} 25=$ primeiro quartil; $\mathrm{Q} 75=$ terceiro quartil 
Tabela 15 - Análise dos escores das perguntas do construto "Práticas" do Questionário CAP em função dos grupos independentes constituídos a partir das respostas a uma pergunta que avalia o mesmo construto em agricultoras do Grupo Expostas

\begin{tabular}{cccccccc}
\hline Variável & $\begin{array}{c}\text { Você acredita que possui praticas } \\
\text { seguras sobre os agrotóxicos? }\end{array}$ & Média & DP & Q25 & Mediana & Q75 & p-valor \\
\hline \multirow{2}{*}{ Práticas de precaução } & Sim & 90,28 & 11,95 & 85,71 & 85,71 & 100,00 & 0 \\
& Não & 90,36 & 13,50 & 85,71 & 100,00 & 100,00 & 0,608 \\
Práticas seguras em casa & Sim & 76,17 & 24,19 & 60,00 & 80,00 & 100,00 & 0 \\
& Não & 78,81 & 22,46 & 60,00 & 80,00 & 100,00 & 0,578 \\
Práticas referentes a animais domésticos & Sim & 39,58 & 20,45 & 50,00 & 50,00 & 50,00 & 0 \\
& Não & 43,75 & 20,04 & 50,00 & 50,00 & 50,00 & 0,181 \\
\hline
\end{tabular}

Teste de Mann-Whitney

Legenda: $\mathrm{n}=$ frequência relativa; DP=desvio padrão; Q25=primeiro quartil; Q75=terceiro quartil 


\subsubsection{Validade de Constructo}

Para a análise da validade de construto, as gestantes do Grupo Expostas foram comparadas as gestantes do Grupo Não Expostas a fim de verificar diferenças nos escores dos domínios dos construtos de conhecimento, atitudes e práticas do Questionário CAP. A análise permite inferir que os grupos foram homogêneos para as variáveis idade, nacionalidade, estuda atualmente e renda familiar (Tabela 16 e 17).

Tabela 16 - Análise descritiva das variáveis quantitativas de caracterização em gestantes do Grupo Expostas e do Grupo Não Expostas

\begin{tabular}{ccccccccc}
\hline Variável & Grupo & $\mathrm{n}$ & Média & $\mathrm{DP}$ & $\mathrm{Q} 25$ & Mediana & Q75 & p-valor \\
\hline \multirow{2}{*}{ Idade } & Gestante exposta & 320 & 26,59 & 6,22 & 22,30 & 26,31 & 32,21 & \multirow{2}{*}{0,445} \\
& Gestante não exposta & 62 & 25,89 & 6,90 & 21,14 & 24,55 & 31,98 & \\
\multirow{2}{*}{$\begin{array}{c}\text { Número de gestações } \\
\text { anteriores }\end{array}$} & Gestante exposta & 320 & 2,02 & 1,06 & 1,00 & 2,00 & 3,00 & \multirow{2}{*}{$0,034^{*}$} \\
& Gestante não exposta & 62 & 1,65 & 0,68 & 1,00 & 2,00 & 2,00 & \\
\hline
\end{tabular}

Teste de Mann-Whitney

Legenda: n=frequência relativa; DP=desvio padrão; Q25=primeiro quartil; Q75=terceiro quartil 
Tabela 17 - Análise descritiva das variáveis qualitativas nominais de caracterização em gestantes do Grupo Expostas e do Grupo Não Expostas

\begin{tabular}{|c|c|c|c|c|c|}
\hline \multirow[b]{2}{*}{ Variável } & \multirow[b]{2}{*}{ Categoria } & & \multicolumn{2}{|c|}{ Grupo } & \multirow[b]{2}{*}{$\mathrm{p}$-valor } \\
\hline & & & $\begin{array}{l}\text { Gestante } \\
\text { exposta }\end{array}$ & $\begin{array}{l}\text { Gestante não } \\
\text { exposta }\end{array}$ & \\
\hline \multirow{4}{*}{ Nacionalidade } & \multirow{2}{*}{ Brasileira } & $\mathrm{n}$ & 310 & 62 & \multirow{4}{*}{0,377} \\
\hline & & $\%$ & $96,9 \%$ & $100,0 \%$ & \\
\hline & \multirow{2}{*}{ Estrangeira } & $\mathrm{n}$ & 10 & 0 & \\
\hline & & $\%$ & $3,1 \%$ & $0,0 \%$ & \\
\hline \multirow{18}{*}{ Grau de escolaridade } & \multirow{2}{*}{ Ensino Fundamental (1-4 anos) } & $\mathrm{n}$ & 16 & 4 & \multirow{18}{*}{$<0,001^{*}$} \\
\hline & & $\%$ & $5,0 \%$ & $6,5 \%$ & \\
\hline & \multirow{2}{*}{$\begin{array}{l}\text { Ensino Fundamental Incompleto } \\
\qquad(1-4 \text { anos })\end{array}$} & $\mathrm{n}$ & 8 & 0 & \\
\hline & & $\%$ & $2,5 \%$ & $0,0 \%$ & \\
\hline & \multirow{2}{*}{ Ensino Fundamental (5-8 anos) } & $\mathrm{n}$ & 38 & 6 & \\
\hline & & $\%$ & $11,9 \%$ & $9,7 \%$ & \\
\hline & \multirow{2}{*}{$\begin{array}{l}\text { Ensino Fundamental Incompleto } \\
\qquad \text { (5-8 anos) }\end{array}$} & $\mathrm{n}$ & 58 & 8 & \\
\hline & & $\%$ & $18,1 \%$ & $12,9 \%$ & \\
\hline & \multirow{2}{*}{ Ensino Médio } & $\mathrm{n}$ & 93 & 11 & \\
\hline & & $\%$ & $29,1 \%$ & $17,7 \%$ & \\
\hline & \multirow{2}{*}{ Ensino Médio Incompleto } & $\mathrm{n}$ & 28 & 10 & \\
\hline & & $\%$ & $8,8 \%$ & $16,1 \%$ & \\
\hline & \multirow{2}{*}{ Curso Técnico } & $\mathrm{n}$ & 1 & 10 & \\
\hline & & $\%$ & $0,3 \%$ & $16,1 \%$ & \\
\hline & \multirow{2}{*}{ Ensino Superior } & $\mathrm{n}$ & 58 & 4 & \\
\hline & & $\%$ & $18,1 \%$ & $6,5 \%$ & \\
\hline & \multirow{2}{*}{ Ensino Superior Incompleto } & $\mathrm{n}$ & 20 & 9 & \\
\hline & & $\%$ & $6,3 \%$ & $14,5 \%$ & \\
\hline \multirow{4}{*}{ Estuda atualmente } & \multirow{2}{*}{ Sim } & $\mathrm{n}$ & 57 & 18 & \multirow{4}{*}{0,054} \\
\hline & & $\%$ & $17,8 \%$ & $29,0 \%$ & \\
\hline & \multirow{2}{*}{ Não } & $\mathrm{n}$ & 263 & 44 & \\
\hline & & $\%$ & $82,2 \%$ & $71,0 \%$ & \\
\hline \multirow{8}{*}{ Renda familiar } & \multirow{2}{*}{$<1$ salário } & $\mathrm{n}$ & 101 & 27 & \\
\hline & & $\%$ & $31,6 \%$ & $43,5 \%$ & \\
\hline & 12 salários & $\mathrm{n}$ & 143 & 24 & \\
\hline & $1-2$ salarios & $\%$ & $44,7 \%$ & $38,7 \%$ & 0081 \\
\hline & 23 solórios & $\mathrm{n}$ & 21 & 0 & 0,081 \\
\hline & L-3 salarios & $\%$ & $6,6 \%$ & $0,0 \%$ & \\
\hline & & $\mathrm{n}$ & 55 & 11 & \\
\hline & $\mathrm{SC}$ & $\%$ & $17,2 \%$ & $17,7 \%$ & \\
\hline & $1^{\circ}$ & $\mathrm{n}$ & 89 & 19 & \\
\hline & 1 & $\%$ & $27,8 \%$ & $30,6 \%$ & \\
\hline Trimestre oestacional & $2^{\circ}$ & $\mathrm{n}$ & 105 & 30 & $0014 *$ \\
\hline Irimestre gestacional & 2 & $\%$ & $32,8 \%$ & $48,4 \%$ & 0,014 \\
\hline & 30 & $\mathrm{n}$ & 126 & 13 & \\
\hline & $J$ & $\%$ & $39,4 \%$ & $21,0 \%$ & \\
\hline
\end{tabular}

Teste Exato de Fisher e Qui-Quadrado de Pearson

Legenda: $n=$ frequência relativa; \%=frequência percentual 
Devido a distribuição não-normal dos escores quantitativos foi utilizado Teste de MannWhitney para comparação dos escores entre dois grupos independentes.

$\mathrm{Na}$ análise dos escores das perguntas dos construtos conhecimento, práticas e atitudes do Questionário CAP em função dos grupos em agricultoras, observou-se na Tabela 18 que houve diferença estatística entre os grupos, sendo que apenas para o domínio "Atitudes em casa" ( $<0,001)$ o Grupo Expostas apresentou menor escore que o Grupo Não Expostas. 
Tabela 18 - Análise dos escores das perguntas dos construtos “Conhecimento, atitudes e práticas” em função dos grupos em agricultoras

\begin{tabular}{|c|c|c|c|c|c|c|c|c|}
\hline Variável & Grupo & $\mathrm{n}$ & Média & DP & Q25 & Mediana & Q75 & p-valor \\
\hline \multirow{2}{*}{$\begin{array}{c}\text { Conhecimento sobre o prejuízo dos agrotóxicos } \\
\text { para a saúde humana }\end{array}$} & Gestante exposta & 320 & 58,91 & 24,22 & 50,00 & 50,00 & 50,00 & \multirow{2}{*}{0,060} \\
\hline & Gestante não exposta & 62 & 64,52 & 34,34 & 50,00 & 50,00 & 100,00 & \\
\hline \multirow{2}{*}{ Conhecimento sobre população de risco } & Gestante exposta & 320 & 89,84 & 23,79 & 83,33 & 100,00 & 100,00 & \multirow{2}{*}{$<0,001^{*}$} \\
\hline & Gestante não exposta & 62 & 81,18 & 23,66 & 66,67 & 91,67 & 100,00 & \\
\hline \multirow{2}{*}{ Conhecimento sobre vias de intoxicação } & Gestante exposta & 320 & 71,81 & 27,05 & 60,00 & 80,00 & 80,00 & \multirow{2}{*}{0,188} \\
\hline & Gestante não exposta & 62 & 72,26 & 32,86 & 60,00 & 80,00 & 100,00 & \\
\hline \multirow{2}{*}{ Conhecimento dos sintomas de intoxicação } & Gestante exposta & 320 & 74,69 & 26,12 & 66,67 & 77,78 & 100,00 & \multirow{2}{*}{$<0,001 *$} \\
\hline & Gestante não exposta & 62 & 54,84 & 37,74 & 22,22 & 44,44 & 100,00 & \\
\hline \multirow{2}{*}{ Conhecimento sobre riscos dos agrotóxicos } & Gestante exposta & 320 & 59,65 & 22,90 & 43,75 & 68,75 & 81,25 & \multirow{2}{*}{0,564} \\
\hline & Gestante não exposta & 62 & 57,16 & 25,43 & 37,50 & 62,50 & 75,00 & \\
\hline \multirow{2}{*}{ Conhecimento sobre o impacto à saúde } & Gestante exposta & 320 & 60,42 & 26,44 & 50,00 & 66,67 & 83,33 & \multirow{2}{*}{0,405} \\
\hline & Gestante não exposta & 62 & 58,06 & 25,74 & 50,00 & 66,67 & 66,67 & \\
\hline \multirow{2}{*}{ Atitudes em casa } & Gestante exposta & 320 & 63,63 & 12,54 & 60,00 & 60,00 & 60,00 & \multirow{2}{*}{$<0,001 *$} \\
\hline & Gestante não exposta & 62 & 89,68 & 16,89 & 80,00 & 100,00 & 100,00 & \\
\hline \multirow{2}{*}{ Uso de vestimenta adequada no trabalho } & Gestante exposta & 91 & 24,40 & 24,18 & 0,00 & 20,00 & 40,00 & \multirow{2}{*}{-} \\
\hline & Gestante não exposta & 0 & & & & & & \\
\hline \multirow{2}{*}{ Atitudes prejudiciais para o feto } & Gestante exposta & 320 & 82,46 & 21,45 & 87,50 & 87,50 & 100,00 & \multirow{2}{*}{$<0,001^{*}$} \\
\hline & Gestante não exposta & 62 & 69,96 & 19,40 & 62,50 & 75,00 & 87,50 & \\
\hline \multirow{2}{*}{$\begin{array}{l}\text { Responsabilidade para uso seguro dos agrotóxicos, } \\
\text { ler rótulo das embalagens }\end{array}$} & Gestante exposta & 320 & 94,06 & 23,67 & 100,00 & 100,00 & 100,00 & \multirow{2}{*}{$<0,001^{*}$} \\
\hline & Gestante não exposta & 62 & 40,32 & 49,45 & 0,00 & 0,00 & 100,00 & \\
\hline \multirow{2}{*}{$\begin{array}{l}\text { Responsabilidade para uso seguro dos agrotóxicos, } \\
\text { reutilização das embalagens }\end{array}$} & Gestante exposta & 320 & 74,06 & 43,90 & 0,00 & 100,00 & 100,00 & \multirow{2}{*}{$0,041^{*}$} \\
\hline & Gestante não exposta & 62 & 61,29 & 49,11 & 0,00 & 100,00 & 100,00 & \\
\hline \multirow{2}{*}{ Uso de agrotóxicos e cuidados } & Gestante exposta & 209 & 38,82 & 13,38 & 28,57 & 42,86 & 42,86 & \multirow{2}{*}{$<0,001^{*}$} \\
\hline & Gestante não exposta & 10 & 2,86 & 9,04 & 0,00 & 0,00 & 0,00 & \\
\hline \multirow{2}{*}{ Motivos para uso de agrotóxicos em casa } & Gestante exposta & 201 & 31,23 & 20,59 & 11,11 & 33,33 & 44,44 & \multirow{2}{*}{-} \\
\hline & Gestante não exposta & 0 & & & & & & \\
\hline \multirow{2}{*}{ Motivos para uso de agrotóxicos no trabalho } & Gestante exposta & 148 & 15,54 & 14,76 & 0,00 & 16,67 & 29,17 & \\
\hline & Gestante não exposta & 0 & & & & & & - \\
\hline & Gestante exposta & 320 & 89,38 & 14,60 & 85,71 & 85,71 & 100,00 & \\
\hline Práticas de precaução & Gestante não exposta & 62 & 75,81 & 28,17 & 71,43 & 85,71 & 85,71 & $<0,001^{*}$ \\
\hline & Gestante exposta & 224 & 78,30 & 22,31 & 60,00 & 80,00 & 100,00 & \\
\hline Praticas seguras em casa & Gestante não exposta & 0 & & & & & & - \\
\hline & Gestante exposta & 320 & 42,50 & 20,34 & 50,00 & 50,00 & 50,00 & \\
\hline Práticas referentes a animais domésticos & Gestante não exposta & 62 & 50,00 & 0,00 & 50,00 & 50,00 & 50,00 & $0,003^{*}$ \\
\hline
\end{tabular}

Teste de Mann-Whitney

Legenda: n=frequência relativa; DP=desvio padrão; Q25=primeiro quartil; Q75=terceiro quartil 
Foi utilizado o Teste Exato de Fisher e o Teste Qui-Quadrado de Pearson para associar os domínios ou questões qualitativas nominais e os grupos. Observou-se que houve associação entre o domínio "conhecimento sobre outros efeitos dos agrotóxicos" e a resposta não no Grupo Expostas $(\mathrm{p}=0,012)$. 

6- Discussão 



\section{DISCUSSÃO}

Os resultados e discussão foram ordenados segundo os objetivos propostos, iniciandose com a análise descritiva dos resultados, que tem por finalidade apresentar, resumidamente e descrever os aspectos importantes das características observadas nos dados, seguido pela discussão dos dados de confiabilidade, obtida entre os dois observadores e, a seguir, apresentase a aferição da validade do instrumento. O questionário original que motivou o presente estudo, não apresentou as etapas de validação, apenas tradução e adaptação transcultural, limitando a análise comparativa. Para tal, utilizou-se da literatura pertinente ao assunto para compor a discussão, que segue organizada por etapas de análise.

\subsection{ANÁLISE DESCRITIVA}

Os protocolos CAP são usados mundialmente para avaliar o Conhecimento, as Atitudes e as Práticas de diversos assuntos e em diferentes populações. O instrumento se difere de acordo com a área e o tipo de estudo, já tendo sido aplicado em gestantes, a fim de investigar os cuidados no período pré-natal e exames de rotina (CANDEIAS, 1980; RECENA; CALDAS, 2008; PASIANI, 2012; ALBUQUERQUE, 2014).

Partindo da ideia de que gestantes agricultoras ou residentes em áreas agrícolas e/ou próximo delas, podem estar expostas constantemente a agrotóxicos e seus riscos à saúde, este estudo investigou o conhecimento, as atitudes e as práticas de uma pequena parcela de gestantes em duas regiões do Estado do Paraná, em relação a esses produtos tóxicos, considerando a validação nacional desse instrumento, traduzido e adaptado transcultural por Cassol e Magni (2015). Nessa pesquisa estão descritas a confiabilidade a partir da análise de estabilidade, consistência interna e equivalência, a validade de conteúdo, de critério e de construto com a finalidade de validar o Questionário CAP - Conhecimento, Atitudes e Práticas em gestantes expostas a agrotóxicos.

Embora existam poucas pesquisas, principalmente no Brasil, utilizando protocolos semelhantes a esse, e nenhuma com esse instrumento propriamente dito, algumas inferências podem ser feitas a partir dos resultados obtidos do processo de validação no presente estudo. Quando comparamos os dados dessa pesquisa aos valores obtidos em outros protocolos, com outras populações, observamos algumas controvérsias no que se referem tanto ao conhecimento, as atitudes e as práticas, quanto ao processo de validação, que serão comentadas 
no decorrer desta discussão (GOLDMAN et al., 2004; LORENZ et al., 2012; CASSOL; MAGNI, 2015).

A população total deste estudo foi composta de 382 gestantes, divididas em grupo de gestantes expostas $(n=320)$ e não expostas $(n=68)$ a agrotóxicos. A $10^{a}$ Regional de Saúde, que abrange a região Oeste do Estado do Paraná teve participação expressivamente maior $(n=320$; $84 \%$ ) que a $4^{\mathrm{a}}$. Regional de Saúde, correspondente a região Sudeste do estado ( $\left.n=62 ; 16 \%\right)$. Possivelmente em função da $10^{\text {a }}$ Regional de Saúde abranger uma população maior $(<502$ mil habitantes), distribuídos em 25 municípios, enquanto a 4 Regional de Saúde compreende pouco mais de 155 mil habitantes, em 9 municípios (SESA/PR, 2020; MPPR, 2020).

$\mathrm{Na}$ análise demográfica do grupo de gestantes expostas, notou-se que a média de idade foi de 26 anos e seis meses, e os trimestres de gestação mostram uma maior participação de gestantes no $3^{\circ}$ trimestre $(\mathrm{n}=126 ; 39,4 \%)$. A maioria das participantes é de nacionalidade brasileira $(n=310 ; 96,9 \%)$ e o grau de escolaridade mais frequente foi o de ensino médio completo ( $n=93 ; 29,1 \%)$, sendo que apenas $17,8 \%$ do total das participantes encontravam-se estudando no momento da pesquisa. Características semelhantes a essas foram encontradas no estudo de tradução, no entanto, a maior participação foi de gestantes no $2^{\circ}$ trimestre (CASSOL; MAGNI, 2015).

Lorenz e colaboradores (2012), em seu estudo, que motivou tanto a tradução quanto a validação do questionário CAP apresentado nesse estudo, também comparou grupo de gestantes expostas e não expostas a agrotóxicos, e a caracterização populacional no que se refere a média de idade e participação por trimestre de gestação foi semelhante a este estudo.

A renda familiar de, aproximadamente $32 \%$ das participantes é de menos de um salário mínimo (R $\$ 975,00)^{13}$, e de 44,7\% entre um e dois salários. De acordo com o último censo realizado, em 2014, o Estado do Paraná possui cerca de 17\% de sua população em área rural, e ganha destaque econômico com o $5^{\circ}$ maior IDH e $6^{\text {a }}$ maior média salarial real habitual das unidades federativas, com uma renda média per capita de R $2.552,00$. Esse dado vai de acordo com a análise de crescimento econômico do país, que, tomando como referência PIB, renda per capita e produção setorial dos entes federativos, as regiões Sul e Sudeste respondem por mais

\footnotetext{
${ }^{13}$ Valores referentes a média do salário Mínimo Brasileiro vigente entre 2018 e 2019 segundo o Diário Oficial da União. Disponível em: http://www.in.gov.br/materia//asset_publisher/Kujrw0TZC2Mb/content/id/57510734/do1esp-2019-01-01-decreto-n-9-661-de-1-de-janeiro-de2019-57510684. Acesso em março de 2020.
} 
de $70 \%$ da produção e da renda, acomodando $56 \%$ da população brasileira (IBGE/PNAB, 2014).

Nas gestantes que participaram desse estudo, notou-se renda média familiar baixa, e isso interfere negativamente no acesso dessas mulheres aos serviços de saúde, uma vez que renda familiar e escolaridade materna são considerados como os principais determinantes para a realização de pré-natal adequado (COIMBRA et al., 2003; CESAR et al., 2008; SILVEIRA et al., 2008; SAAVEDRA; CESAR, 2015). Evidências apontam que apesar de quase a totalidade das gestantes brasileiras $(98 \%)$ ) começar o pré-natal, quanto melhor a renda das mulheres, maior a participação nos procedimentos e exames relativos ao pré-natal (CESAR et al., 2008; BRASIL, 2012; VIELLAS et al., 2014).

Nesse cenário agroeconômico e social, cabe destacar que as mulheres agricultoras não são apenas responsáveis pela manutenção e reprodução do núcleo familiar e do trabalho doméstico, mas também trabalham na agricultura e são responsáveis por contribuir para a sobrevivência e produtividade do grupo familiar, desempenhando atividades agrícolas (hortas, pequenos campos e processamento de alimentos) e cuidar de animais (PAULINO, 2004; HEREDIA; CINTRÃO, 2006).

De um modo geral, a participação da renda agrícola para as mulheres é muito menor em relação a dos homens, mesmo que elas participem ativamente nas tarefas rurais, principalmente em propriedades familiares (conta-própria). Culturalmente e socialmente é construída a ideia de que cabem às mulheres o trabalho do lar e reprodutivo, e aos homens o produtivo. Em geral, para as mulheres, o trabalho da terra tem sido interpretado como uma extensão do trabalho doméstico (RAIMUNDO STADUTO; ALVES NASCIMENTO; DE SOUZA, 2013).

Referente a ocupação das Gestantes Expostas, mais da metade (54,38\%) relata trabalhar desde que ficou grávida, $60 \%$ permanece trabalhando, e aproximadamente $25 \%$ em trabalho que envolve a agricultura.

De maneira geral, o Brasil é conhecido mundialmente por seu potencial produtivo e de exportação agrícola, e dentre os estados com maior destaque, encontra-se o estado do Paraná, que tem como base a agricultura, sendo seu principal setor econômico que impulsiona seu crescimento ao longo dos anos (IPARDES, 2016; SOUZA JUNIOR; BALDISSERA; BERTOLINI, 2019)

O estado do Paraná tem 399 municípios, subdivididos em 10 mesorregiões: centroocidental, centro-oriental, centro-sul, metropolitana de Curitiba, noroeste, norte central, norte pioneiro, oeste, sudeste e sudoeste. Desses, praticamente 80\% (317 dos 399) dos municípios do estado tem menos que 20.000 habitantes, sendo que $70 \%$ é vinculado à agricultura familiar 
(IPARDES, 2017). De acordo com o último Censo Agropecuário de 2017, possui 305 mil estabelecimentos agropecuários, distribuídos em 14,7 milhões de hectares (ha) por $\mathrm{m}^{2}$, ocupando cerca de 847 mil pessoas nas atividades de agropecuária (IBGE, 2017).

Segundo esse censo, $13 \%$ dos estabelecimentos agropecuários paranaenses é representado mulheres, e $86 \%$ por homens, sendo uma economia fundamentada num ciclo econômico de produção de grãos, cereais e carnes, que atende mercados regionais, nacionais e internacionais, principalmente com soja, carnes e automóveis (IPARDES, 2016).

O estado, outrora considerado o "celeiro agrícola" do País, por ser o principal fornecedor de matéria-prima da agroindústria, ocupa atualmente o quinto lugar em produção nacional e possui sua estrutura fundiária com predomínio de pequenas fazendas, distribuídas por todo o território, predominantemente dominadas por agriculturas familiares, que tem se mantido sustentáveis diante de toda mecanização da agricultura, participando ativamente da construção de novos modelos de desenvolvimento rural (BAIARDI; ALENCAR, 2014; PARANÁ, 2016). Seu solo fértil e a topografia da região favorecem diversificação na produção agrícola paranaense, e seu potencial produtivo está na cultura de cereais como o milho, o trigo e a soja, que já foram recordistas de safras entre os demais estados brasileiros. Outros produtos que são relevantes na produção são café, arroz, feijão, cana-de-açúcar e fumo. A modernização agrícola do estado também fortaleceu esse processo, por meio da mecanização, eletrificação, irrigação, conservação do solo, uso de fertilizantes e agrotóxicos (PRIORI et al., 2012; PARANÁ, 2016).

A diversificação na produção rural é a exploração de diversas culturas na agricultura como uma estratégia para minimizar as incertezas do ambiente de negócios, reduzindo o risco de produzir uma única cultura e ter alto impacto de fatores externos na produção, como o clima, a economia de mercado, pragas e doenças. Com a sua adoção, é possível obter vantagens ambientais e ganhos econômicos diretos e indiretos na redução dos custos de produção, além de reduzir os riscos de se ter apenas uma atividade como principal fonte de renda e manutenção da agricultura familiar (PARANÁ, 2016).

O trabalho do campo desempenhado pelas mulheres é muitas vezes considerado como "ajuda" e não aparece nas estatísticas oficiais como trabalho produtivo, o que inviabiliza o seu reconhecimento enquanto trabalhadora rural, consequentemente dificultando o acesso aos direitos essenciais de saúde e previdência, salário maternidade e aposentadoria, garantidos por lei desde a Constituição de 1988 (BRASIL, 1988; MAIA; LOPES, 2001).

Na prática o que se observa é que a mulher, em seu universo de fazeres, trabalha e vive, interagindo no espaço rural, sendo educadora, mãe, companheira, trabalhadora e agente 
política, e no desempenho de seus múltiplos papéis, acaba por produzir espaços que podem diluir importâncias e riscos referentes à sua participação na execução de atividades produtivas (OLIVEIRA; NINA, 2014).

Este fato não é exclusivo da população desse estudo, pois pode ser verificado em várias partes do mundo, assim como é observado no espaço das comunidades rurais, através do trabalho, participação e responsabilidades assumidas por ela (OLIVEIRA; NINA, 2014). No entanto, em função da desvalorização dessas atividades, na maioria não remuneradas, é que se observa uma dificuldade no reconhecimento da identidade de agricultora, como ocorreu nesse estudo, em que muitas mulheres que residem no campo, e executam atividades referentes ao lar, inerentes a agricultura, não se denominam agricultoras, auto definindo sua profissão/ocupação como "do lar" ou "dona-de-casa", o que, no entanto, não as priva da exposição a produtos agrotóxicos, que danificam sua saúde, e de seu bebê.

Ainda sobre a ocupação das gestantes, a maioria $(72,19 \%)$ relata que há um ano atrás trabalhou, contra uma pequena parcela $(27,81 \%)$ que não trabalhou; dentre a parte que referiu trabalhar, aproximadamente 33\% parou sua ocupação após saber da gravidez, enquanto mais de $60 \%$ afirmaram não ter parado de trabalhar.

No Brasil, apenas 20,3\% dos estabelecimentos agropecuários são conduzidos por casais, dividindo todas ou parte das responsabilidades relativas ao estabelecimento, e na análise individual, apenas $18,7 \%$ do trabalho agrícola é ocupado por mulheres, e outros $81 \%$ é comandado por homens (IBGE, 2017). Dentre todos os estados brasileiros, o Paraná está entre os que tem menos participação, sendo de $10 \%$ a $15 \%$ (FIGURA 15). 
Figura 105 - Distribuição de Estabelecimentos com produtor do sexo feminino, por Unidade da Federação

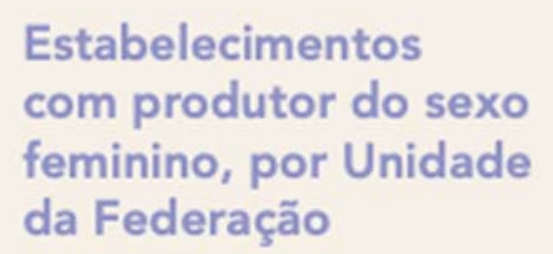

De $10 \%$ a $15 \%$

De $15 \%$ a $20 \%$
De $20 \%$ a $25 \%$

De $25 \%$ a $30 \%$

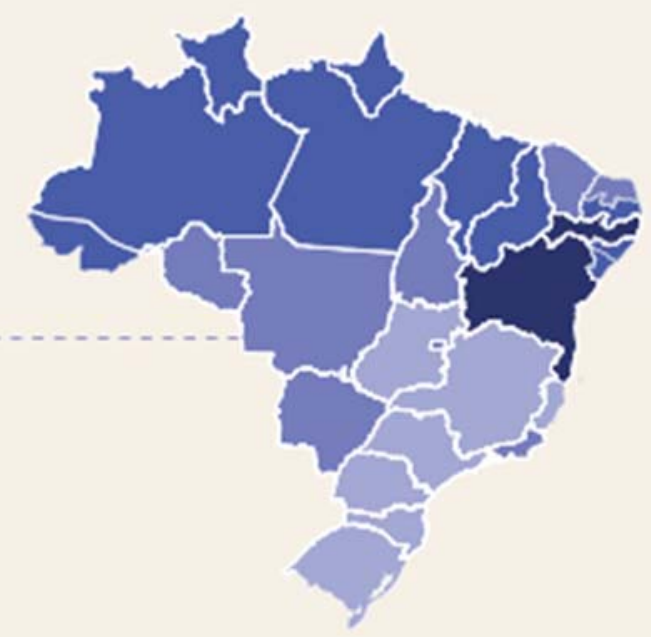

Fonte: IBGE, Censo Agropecuário 2017.

Um estudo cubano demonstrou que as mulheres representam $46 \%$ da força de trabalho ativa do país, e mesmo conseguindo desempenhar tarefas essenciais na indústria agrária cubana, os avanços não correspondem às medidas adotadas nem visam alcançar a igualdade como objetivo fundamental (LISBOA; LUSA, 2010).

Historicamente, as mulheres estão ligadas ao trabalho agrícola como companheiras permanentes dos homens e desempenhavam um papel de liderança em determinadas tarefas, que no decorrer do desenvolvimento das comunidades, o trabalho acabou sendo restringido às tarefas domésticas. Inicialmente, se atrelou à diferenças biológicas díspares, descontruídas com o passar do tempo (MONTENEGRO; LEIVA, 2017). Recentemente, as mulheres têm tomado seu lugar na atividade agrícola, com participação mais ativa, especialmente no contexto da agricultura familiar, possivelmente em função das mudanças e da crise econômica (OLIVEIRA; NINA, 2014). A incorporação de mulheres é essencial para o crescimento e desenvolvimento em diferentes setores, ligados ou não a agricultura, bem como, seu fortalecimento em termos de autonomia econômica, capacidade de gerar recursos e renda própria, tornando-as financeiramente independentes, possibilitando melhor qualidade de vida (MONTENEGRO; LEIVA, 2017).

Em estudo realizado no Paraná, que pretendeu verificar as formas de ocupações e fontes de renda de mulheres e homens das famílias das áreas rurais do estado, verificou que o número das famílias no período de 2001 e 2008 ficou estabilizado, após intensa queda que ocorreu na década de 1990. No entanto, foi constatado intensa redução das ocupações agrícolas e o 
preocupante processo de empobrecimento da classe média, atingindo mais intensamente as mulheres, sendo um importante fator para as mulheres buscarem renda em ocupações externas à agricultura. Mesmo diante desse cenário, a renda dos homens oriunda das ocupações agrícolas ainda é a maior responsável pela formação da renda (RAIMUNDO STADUTO; ALVEZ NASCIMENTO; DE SOUZA, 2013).

Situações como essa, podem justificar a intensa migração rural-urbano ocorrida nas últimas décadas entre jovens do sexo feminino, gerando uma relativa masculinização e envelhecimento da população do campo no Brasil (CAMARANO, ABRAMOVAY, 1999; CASTRO; AQUINO, 2008; RAIMUNDO STADUTO, ALVEZ NASCIMENTO, DE SOUZA, 2013). Estudos apontam algumas situações que conduzem a esse processo demográfico: a condição de subalternidade da mulher nas relações familiares; desvalorização das atividades que desempenham na agricultura familiar (BRUMER, 2006); dificuldade em distinguir entre as atividades de produção e reprodução (ABRAMOVAY; DA SILVA, 2000); o pouco espaço destinado às mulheres na atividade agrícola comercial, na qual atuam apenas como auxiliares (LOMBARDI, 2006; BRUMER, 2006); dificuldade de acesso a terra, porque prevalecem os contratos sociais que privilegiam os homens na transmissão da herança e na direção da propriedade rural (DEERE; LEÓN, 2002; DEERE, 2004; GÓMEZ GARCÍA; RICO GONZÁLEZ, 2004; SPANEVELLO, 2008); mais oportunidades de as mulheres encontrarem emprego no centro urbano em relação ao rural (GÓMEZ GARCÍA; GONZÁLEZ, 2004); distribuição do poder intrafamiliar de decisão de alocação dos recursos da propriedade desfavorável às mulheres (HERNÁNDEZ, 2009); e ao árduo trabalho desenvolvido nos ambientes rurais (MELLO, et al., 2003).

A respeito das condições de saúde dessas mulheres, de um modo geral, as mulheres rurais têm menos acesso a redes de apoio e aos serviços de saúde e assistência, muitas vezes justificáveis pela dificuldade de locomoção até as unidades de saúde, localizadas nos centros urbanos dos municípios, seja por não terem veículo próprio ou por dependerem de serviços de transporte público, que muitas vezes, não existe. Acrescenta-se a isso o fato delas terem menos infraestrutura e tecnologias para apoiar nas tarefas domésticas (BERCOVICH, 2014).

Sobre o planejamento ocupacional relacionado a gestação, aproximadamente $30 \%$ relata que irá parar de trabalhar apenas quando o médico determinar ou quando não puder mais trabalhar, enquanto que outra parcela semelhante pretende trabalhar até dar à luz, e outras 37\% ainda não sabem se pararão. Após dar à luz, grande parte das gestantes $(78,44 \%)$ pretende trabalhar, e uma minoria (16,56\%) não pretende retornar, ou não sabe ainda (5\%). Muitas acreditam que esse retorno se dará entre 3 meses após dar à luz (35,63\%), algumas planejam 
voltar entre 3 e 6 meses após dar à luz (9,38\%) ou 6 meses após dar à luz (7,5\%), e várias ainda tem conhecimento $(47,5 \%)$.

Os avanços no acesso universal às políticas de saúde para a população brasileira são inquestionáveis, entretanto, novos desafios apresentam-se como resultante dos contextos de mudanças sociais, econômicas e demográficas, da transição epidemiológica, das situações de vulnerabilidades sociais, bem como, em relação ao reconhecimento e à afirmação dos direitos relacionados à diversidade cultural e especificidades de crianças com deficiências, indígenas, negras, quilombolas, ciganas, crianças em situação de rua, em serviços de acolhimento, filhos e/ou filhas de mulheres no sistema prisional e na população rural e das águas (BRASIL, 2012b).

O Ministério da Saúde e Agricultura entende as populações do campo, da floresta e das águas, como povos e comunidades com modos de vida, produção e reprodução social relacionados predominantemente com o campo, a floresta, os ambientes aquáticos, a agropecuária e o extrativismo, tais como: camponeses; agricultores familiares, trabalhadores rurais assalariados e temporários que residem ou não no campo, trabalhadores rurais assentados e acampados, populações que habitam ou usam reservas extrativistas, populações ribeirinhas, populações atingidas por barragens e outras comunidades tradicionais (BRASIL, 2012b; 2013). No Brasil, essa população é representada por $19 \%$ do total populacional, ou seja, aproximadamente 30 milhões de pessoas residem em localidades rurais, em aproximadamente 8,1 milhões de domicílios (BRASIL, 2013).

As condições de saúde dessas populações evidenciam as limitações de acesso e qualidade nos serviços de saúde, bem como deficiência na área de saneamento ambiental, ou seja, uma situação ainda mais precária se comparada com a da população urbana. É no campo que se encontram "os maiores índices de mortalidade infantil, de incidência de endemias, de insalubridade e de analfabetismo", caracterizando situação de pobreza extrema, decorrente das dificuldades ao acesso a bens e serviços necessários à sobrevivência (BRASIL, 2013, p. 13).

Diante dessa realidade e motivados a mudá-la, políticas e programas públicos foram instituídos, pretendendo melhor assistência a essas populações, como é o caso da Política Nacional de Saúde Integral da População Negra (BRASIL, 2009), Programa Brasil Quilombola (BRASIL, 2003) e a Política Nacional de Saúde Integral das Populações do Campo e da Floresta (PNSIPCF) (BRASIL, 2011). Dentre as ações propostas, se destacam a qualificação dos profissionais da Atenção Básica para detecção precoce de doenças e agravos que acometem essas populações, estímulo ao aleitamento materno até 2 anos ou mais, com o aleitamento materno exclusivo nos primeiros 6 meses, atenção pré-natal qualificada, incluindo o cuidado de parteiras capacitadas para detecção de complicações gestacionais e referenciamento 
oportuno no parto e nascimento que necessitam de encaminhamento para serviço especializado e Atenção Hospitalar, respeito a diversidades culturais, práticas e saberes no cuidado na gravidez, parto e nascimento, dentre outras (BRASIL, 2009; 2003; 2011).

De modo geral, no Brasil, diversas políticas e mobilizações sociais de saúde maternoinfantil são realizadas a fim de melhor atender a saúde de mulheres e crianças, e proteger o aleitamento materno, a citar as Semanas Mundiais de Aleitamento Materno, Programa Empresa Cidadã (Lei n. ${ }^{\circ} 11.770 / 2008$ ) que prorroga por 60 dias a duração da licença-maternidade, e a ampliação da licença-paternidade para 15 dias (Lei n. ${ }^{\circ}$ 13.257/2016), a Norma Brasileira de Comercialização de Alimentos para lactentes, crianças de primeira infância, bicos, chupetas e mamadeiras (NBCAL) (Lei n. ${ }^{\circ}$ 11.265/2006) que estabelece critérios para a comercialização de alimentos para lactentes e crianças de primeira infância, além de produtos de puericultura correlatos, além da implementação da Política Nacional de Atenção Integral à Saúde da Mulher: princípios e diretrizes (BRASIL, 2004; 2006; 2008; 2016; SANTOS et al., 2008).

Mesmo diante de todas essas mudanças, e no que se refere ao contexto sociocultural e político da saúde da mulher agricultora e/ou que reside no campo, na prática registraram-se mudanças pouco significativas. O Brasil, em seu amplo território, possui muitas regiões distantes, e as populações que nela vivem têm dificuldades no acesso regular aos sistemas de saúde, sendo esse um grande desafio a ser enfrentado. Além disso, no que se refere a gestante que reside no campo, muitos fatores socioculturais e econômicos continuavam implicando a condição desfavorável para a mulher, como já citados anteriormente (CARVALHO; JESUS; SENRA, 2017).

No entanto, essa não é uma realidade exclusiva do Brasil. Outros países também enfrentam desafios semelhantes, como é o caso da África Austral, que além das barreiras socioeconômicas e culturais, a mulher ainda é figura subalterna ao marido, e depende dele a decisão da procura médica ou não. Após a Conferência Mundial sobre a Mulher em BeijingChina, em setembro de 1995, o governo implementou diversos projetos de cursos de curta e/ou longa duração voltados a formação educacional da mulher e incentivo ao trabalho, e autovalorização feminina (LOURENCO; TYRRELL, 2009).

Acerca dos recursos médicos utilizados para realização do pré-natal, no questionário CAP, a gestante poderia assinalar mais de um, caso o usasse, e o destaque foi o Sistema Único de Saúde (SUS), representado por mais de 70\% das usuárias, seguido da saúde suplementar $\operatorname{com} 23 \%$.

O Sistema Único de Saúde (SUS) é um dos maiores e mais complexos sistemas de saúde pública do mundo, abrangendo desde o simples atendimento para avaliação da pressão 
arterial, por meio da Atenção Primária, até o transplante de órgãos, garantindo acesso integral, universal e gratuito para toda a população do país. Com a sua criação, o SUS proporcionou o acesso universal ao sistema público de saúde, sem discriminação. A atenção integral à saúde, e não somente aos cuidados assistenciais, passou a ser um direito de todos os brasileiros, desde a gestação e por toda a vida, com foco na saúde com qualidade de vida, visando a prevenção e a promoção da saúde (BRASIL, 2006; 2016; 2011a; 2011b; 2011c, 2013).

A fim de atender às necessidades de atenção à saúde das populações do campo, por meio da PNSIPCF, objetiva-se melhorar o nível de saúde das populações do campo e da floresta, por meio de ações e iniciativas que reconheçam as especificidades de gênero, de geração, de raça/cor, de etnia e de orientação sexual, objetivando o acesso aos serviços de saúde; a redução de riscos à saúde decorrentes dos processos de trabalho e das inovações tecnológicas agrícolas; e a melhoria dos indicadores de saúde e da sua qualidade de vida. Por ser uma política transversal, prevê ações compartilhadas entre as três esferas de governo cuja articulação às demais políticas do MS é imprescindível, e sua implementação nos estados e municípios depende de toda a população, do governo e da sociedade civil (BRASIL, 2013; 2014).

Pensando nessa dificuldade de acesso dos agricultores rurais aos serviços públicos de saúde nos centros urbanos, é que recentemente foi elaborado o Projeto de Lei 2295/19, que prioriza no SUS, o atendimento ao agricultor familiar que more a mais de 50 quilômetros do local de consulta, incluindo os agricultores na Lei do Atendimento Prioritário (10.048/00), que hoje beneficia as pessoas com deficiência, os idosos, as gestantes, as lactantes, as pessoas com crianças de colo e os obesos nos serviços de atendimento ao público. O projeto ainda tramita em caráter conclusivo e será analisado pelas comissões de Seguridade Social e Família, e de Constituição e Justiça e de Cidadania (BRASIL, PL 2295/2019).

A média de consultas que as gestantes deste estudo participaram foi de 2,51 vezes, e sobre o mês da primeira visita ao programa foi de 2,16 meses de gestação.

É inegável a importância do acompanhamento pré-natal para a prevenção e/ou detecção precoce de patologias, tanto maternas como fetais, permitindo um desenvolvimento saudável do bebê e reduzindo os riscos da gestante. Esse é um momento fundamental para a troca de diferentes vivências entre as mulheres e os profissionais de saúde, sendo considerada a melhor maneira de promover a compreensão do processo de gestação (BRASIL, 2000).

No Brasil, são observados constantes investimentos na busca pela qualificação da atenção à saúde materno-infantil, a citar a instituição do Programa de Humanização no PréNatal e Nascimento (PHPN), a implantação da Rede Cegonha e a recente Política Nacional de Atenção Integral à Saúde da Criança (PNAISC), que além de orientarem as práticas a este grupo 
populacional, organizam os serviços de saúde em nível nacional (BRASIL, 2015; 2011b; SANINE, CASTANHEIRA, 2018; SANINE et al., 2019).

Esses programas são baseados nas análises das necessidades de atenção específica à gestante, ao recém-nascido e à mulher no período pós-parto, e de maneira geral, buscam reduzir as altas taxas de morbi-mortalidade materna e perinatal, assegurar a melhoria do acesso, da cobertura e da qualidade do acompanhamento pré-natal, da assistência ao parto, puerpério e neonatal, e ampliar as ações já adotadas pelo MS na área de atenção à gestante, como os investimentos nas redes estaduais de assistência à gestação de alto risco, o incremento do custeio de procedimentos específicos e outras ações. Os programas de humanização garantem a toda gestante o direito ao acesso a atendimento digno e de qualidade no decorrer da gestação, parto e puerpério, de conhecer e ter assegurado o acesso à maternidade em que será atendida no momento do parto, direito à assistência ao parto e ao puerpério e que seja realizada de forma humanizada e segura, de acordo com os princípios gerais e condições estabelecidas pelo conhecimento médico: e ao recém-nascido o direito à assistência neonatal de forma humanizada e segura (BRASIL, 2011; 2002; 2000).

Esse esforço permanente de manter a saúde materno-infantil em destaque nas políticas públicas tem demonstrado resultados positivos para o país, como a queda da mortalidade materna e infantil acima da média mundial entre 1990 e 2018, resultado principalmente da melhora na assistência pré-natal e avanço da cobertura vacinal (GDB, 2015; LIU et al., 2016; VENANCIO et al., 2016; BRASIL, 2019). No Brasil, a taxa de mortalidade infantil a cada mil nascidos vivos (NV) em 2017 foi de 12,8/1000, ainda muito acima das taxas de países desenvolvidos, que permeiam menos de 2 a cada mil NV; no Paraná entre 2011 a 2017 a queda foi de 11,65 para 10,36/1000 NV; especificamente nas regionais pesquisadas nesse estudo, em 2017 as taxas finalizaram em 9,41/1000 NV na Regional de Irati e 9,14/1000 NV na Regional de Cascavel, ficando abaixo da média estadual e nacional (IBGE, 2018;2019).

Entretanto, esses avanços nacionais na área da saúde não aconteceram de forma homogênea entre as regiões, e como apresentado nesse estudo, embora reflitam em bom nível de aquisição de conhecimento, não garantem necessariamente atitudes e práticas seguras, principalmente frente a agentes nocivos como os agrotóxicos, evidenciando-se a necessidade de melhoria na qualidade ao cuidado pré-natal, principalmente voltado a essa população agricultora (ANVERSA BASTOS; NUNES; DAL PIZZOL, 2012; VEJA; SOARES; NASR, 2017; SANINE et al., 2019). 


\subsection{ANÁLISE DO CONHECIMENTO, DAS ATITUDES E DAS PRÁTICAS}

Caracteriza-se como "Conhecimento" a informação sobre o treinamento para uso dos agrotóxicos, rotas de exposição e riscos envolvidos, efeitos agudos e crônicos sobre a saúde, sintomas da toxicidade e métodos efetivos para prevenir a exposição. Considerando que quanto maior a média de "Conhecimento", maior é o conhecimento da gestante sobre o assunto, foi possível verificar que as gestantes desse estudo possuem alto grau de conhecimento sobre todos os itens relacionados (Tabela 6).

Em estudo anterior a este, onde se realizou a tradução deste mesmo questionário, as análises foram realizadas por trimestre de gestação e as gestantes de maneira geral demonstraram conhecimento satisfatório sobre os agrotóxicos, sendo que quanto maior o trimestre de gestação, maior foi o conhecimento (CASSOL; MAGNI, 2015). Outros estudos desenvolvidos, utilizando o questionário CAP e com objetivos semelhantes, verificaram que as gestantes também apresentavam altos índices de conhecimento nas respostas, e um deles relacionou com a escolaridade, uma vez que os índices de conhecimento eram maiores nas gestantes com mais alto nível de escolaridade. (RECENA et al., 2006; ZYOUD et al., 2010; LORENZ et al., 2012). O uso de questionário CAP também demonstrou ser eficiente na avaliação de medidas educativas em gestantes, quanto a outros assuntos, como cuidados gestacionais e tabagismo (BERTANI; GARCIA; TANNI; GODOY; 2015; OLIVEIRA et al., 2018).

A maioria das entrevistadas concorda sobre os danos dos agrotóxicos afetarem diferentes populações, independentemente de serem agricultores ou não, bem como, reconhece as principais vias de intoxicação. Considera-se no questionário que entre as populações de risco para intoxicação por agrotóxicos, incluem-se tanto a população geral, como os trabalhadores agrícolas, as pessoas que consomem a colheita, os residentes no campo, e também os residentes de cidades e comunidades próximas às plantações. Sobre as vias de intoxicação dos agrotóxicos seriam a respiração e/ou ingestão dos produtos agrotóxicos, o contato por mordida de mosquito ou diretamente com os produtos tóxicos, e o consumo de alimentos de plantações que fazem uso desses produtos. A respeito dos sinais de intoxicação o questionário pontua: dor de cabeça, lacrimejamento dos olhos, infarto/ataque cardíaco, náuseas/vômitos, salivação excessiva, tosse/ frio/ dor no peito/ falta de ar, erupção/ irritação na pele e coceira, dor abdominal e diarreia, e fraqueza muscular/ fadiga e dor no corpo, e desse total de opções, a maioria das gestantes afirma conhecer estes sinais. 
Nos itens referentes ao conhecimento sobre o prejuízo dos agrotóxicos para a saúde humana e sobre riscos dos agrotóxicos a média apresentou-se mais baixa, entretanto, mantevese acima dos 50\%. As gestantes desse estudo também não demonstram conhecer $(63,75 \%)$ ou não relatam conhecimento $(23,75 \%)$ sobre outros efeitos que os agrotóxicos podem causar, além dos sugeridos pelo questionário.

Os agrotóxicos afetam a saúde humana direta e indiretamente, bem como o meio ambiente em geral, ocasionando desequilíbrio nos biomas. Entretanto, nem todos os impactos são claramente definidos e conhecidos, devido a multiplicidade de fatores envolvidos. Nesse sentido, o conhecimento sobre os riscos de contaminação está intimamente relacionado à forma, através da qual estas populações se relacionam com os perigos existentes, processos estes fortemente enviesados por determinantes de ordens social, cultural e econômica (PERES et al., 2005).

Ressalta-se ainda que, os sinais e sintomas de intoxicação diferem entre agudos e crônicos, classificados em leves, moderados e graves. Entre os sintomas de intoxicação agudos são caracterizados por cefaléia, irritação, dermatite de contato irritativa ou por hipersensibilidade, náusea, vômitos, cólicas abdominais, tonturas, fraqueza generalizada, salivação e sudorese aumentadas, hipotensão, arritmias cardíacas, insuficiência respiratória, edema agudo de pulmão, convulsões, alterações da consciência, choque, coma, podendo evoluir para óbito. Os sintomas crônicos manifestam-se por meio de inúmeras patologias que atingem vários órgãos e sistemas, com destaque para os problemas imunológicos, hematológicos, hepáticos, neurológicos, malformações congênitas e tumores (BRASIL, 2006).

$\mathrm{O}$ alto nível de conhecimento apresentado pelas gestantes desse estudo pode ser consequência positiva dos programas de atenção à saúde da mulher e acompanhamento prénatal (Tabela 6). Nos últimos anos, com a proposta do Programa Estratégia de Saúde da Família, que aproxima a população, em geral, das unidades de cuidados à saúde, intensificou-se a cobertura de acompanhamento pré-natal, diminuindo as gestações de risco e complicações de parto, além das campanhas nos períodos pré e neonatal (BRASIL, 2012).

Especificamente, no estado do Paraná, diversas iniciativas governamentais têm sido executadas a fim de melhor assistir essa população, a citar o programa denominado "Mãe Paranaense", propõe a organização da atenção materno-infantil nas ações de pré-natal e puerpério, e acompanhamento do crescimento e desenvolvimento das crianças, em especial no primeiro ano de vida (PARANÁ, 2013).

Nesse sentido, justifica-se o fato de gestantes que realizam o acompanhamento pré-natal e participam de orientações, palestras e conversas com os profissionais da saúde, apresentarem 
mais conhecimento sobre os cuidados gestacionais e estarem alertas com relação aos possíveis riscos e tomada de precauções para o cuidado integral com seu feto.

Por meio da amostragem deste estudo, é possível hipotetizar que as gestantes conhecem os riscos envolvidos nos produtos agrotóxicos, e isso as leva a tomarem precauções em seu cotidiano, uma vez que o conhecimento destes determinantes é essencial ao entendimento do problema.

No entanto, para o reconhecimento dos riscos e, com isso, o desenvolvimento de cuidados apropriados, é fundamental a ocorrência de atividades e/ou programas educativos, que orientem, esclareçam e ensinem estratégias e formas seguras de cuidados. Na amostra deste estudo, a maioria das gestantes entrevistadas não recebeu treinamento sobre os agrotóxicos $(93,75 \%)$, e apenas 20 gestantes $(6,25 \%)$ que o receberam, relatam que o mesmo foi realizado por intermédio das empresas fornecedoras dos produtos, empresas/cooperativas vinculas ao seu emprego, e sindicatos, há cerca de 2 anos.

Apenas as entrevistadas que referiam ter tido treinamento é que responderam as questões sobre os tópicos discutidos nessa ocasião.

Esses dados conflitam com os achados sobre o conhecimento das gestantes sobre agrotóxicos, uma vez que elas apresentaram altos níveis de conhecimento, no entanto, não receberam treinamento sobre os produtos. Isso pode indicar, que possivelmente esse conhecimento não é advindo de uma instrução ou treinamento, mas algo adquirido por outros meios, como informativos em televisão, jornais e internet, ou adquiridos por meio do saber popular e intergeracional, já que muitas delas são oriundas de famílias agricultoras.

Nenhuma gestante se referiu às Secretarias e Unidades Básicas de Saúde da cidade como promotoras desses cuidados, o que indica uma carência de atividades voltadas a essa população por parte dos órgãos e secretarias de saúde. A ausência de atividades objetivas de orientação e a falta de uma fiscalização mais severa foram apontadas no estudo de Bulow (2008), o qual verificou que a maior parte do conhecimento que os agricultores da região sul do Brasil possui em relação aos agrotóxicos, desde o tipo e a dosagem, até os cuidados a serem tomados, está relacionada às informações emitidas pelos profissionais vinculados aos estabelecimentos comerciais. Este fato retratou uma situação que fere a legislação, uma vez que o receituário agronômico deveria ser emitido a partir de visitas às propriedades por profissionais não vinculados ao setor de comercialização, já que isto representa um interesse implícito para aumentar as vendas, implicando na aplicação de dosagens maiores ou até mais tóxicas que as necessárias. Estudos tem apontado a necessidade de programas de prevenção quanto à 
exposição ao agrotóxico na saúde do trabalhador, com controle e vigilância dos agentes (RECENA et al., 2006; BULOW, 2008; CASSOL; KANAZAWA; SZEKUT; LOPES, 2020).

No sentido de minimizar essa situação, novas políticas tem, gradativamente destinado sua atenção a esse tema. No entanto, para sua efetivação prática, há um longo caminho a ser percorrido. Em 2012, após o MS instituir, por meio da Portaria 2938/2012, a Vigilância em Saúde de Populações Expostas a Agrotóxicos, a SESA-PR elaborou e implantou o Plano Estadual de Vigilância das Populações Expostas aos Agrotóxicos 2013-2016, contendo 14 ações estratégicas. Esse plano visava melhora no diagnóstico de intoxicações agudas e crônicas, além de direcionar orientações para diagnóstico, tratamento, notificação, reabilitação, prevenção e ações de vigilância sanitária e epidemiológica das intoxicações (BRASIL, 2006; PARANÁ, 2013).

Em 2017, decorrente da demanda, a SESA-PR incluiu a assistência à saúde nessa discussão, com foco na exposição e intoxicação por agrotóxico, surgindo o PEVASPEA-PR 2017-2019, com 20 ações estratégicas, com o objetivo de estabelecer ações de vigilância de riscos e agravos, medidas preventivas e de controle do uso de agrotóxicos, além de contribuir para a construção e efetivação de um sistema de vigilância integrado permitindo ao nível federal do SUS, o monitoramento e controle de situações de riscos à saúde humana relacionada aos agrotóxicos (BRASIL, 2009; PARANÁ, 2011). Para melhor execução desse plano, foi apresentado o "Linha Guia da Atenção às Populações Expostas aos Agrotóxicos", lançado pelo governo paranaense em 2018, têm o propósito de subsidiar tecnicamente os profissionais da rede de atenção primária para o acolhimento, diagnóstico, tratamento, notificação e acompanhamento da saúde dos trabalhadores e população exposta aos efeitos agudos e crônicos dos agrotóxicos no Estado (PARANÁ, 2018).

Nesse Linha Guia é possível verificar o passo a passo da aplicação no estado, desde sua organização quanto aos pontos de atenção, suas competências, população-alvo, identificação dos casos suspeitos, avaliação clínica, exame físico e diagnóstico, acompanhamento e seguimento, manejo nos casos de intoxicação, com a padronização dos instrumentos a serem utilizados em todo o estado (PARANÁ, 2018). Uma vez que essa pesquisa foi desenvolvida em parceria com regionais de saúde do Estado do Paraná, foi possível perceber na prática que as etapas do Linha Guia estão sendo desenvolvidas gradativamente, mesmo diante de diferentes obstáculos, que entre os principais, se destaca o engajamento do município na aplicação do Plano.

O constructo "Atitudes" foi obtido com base na média de acertos das questões respondidas que seriam favoráveis a atitudes de responsabilidade para um uso seguro do 
agrotóxico, à susceptibilidade para efeitos na saúde, às razões para usar o agrotóxico. Foi possível verificar que a média de acertos foi baixa nos itens "Uso de vestimenta adequada no trabalho" que se refere ao uso de blusa de manga longa, luvas de algodão, chapéu ou algo cobrindo a cabeça, além de lenço ou máscara para cobrir a sua face e botas de borracha, bem como nos itens "Uso de agrotóxicos e cuidados", "Motivos para o uso de agrotóxicos em casa" e "Motivos para uso de agrotóxicos no trabalho". Esses resultados concordam com o de Lorenz e colaboradores (2012), que encontraram índices menores acerca da responsabilidade para o uso seguro de agrotóxicos, indicando aumento no comportamento de risco em casa, e discorda do estudo de Cassol e Magni (2015) em que mais da metade das gestantes afirmaram ter essa atitude, enquanto que nesse, a média de acertos foi inferior a $30($ média $=24,40)$. Outro estudo nacional demonstrou que referente as práticas em saúde, a maioria dos agricultores no estado do Mato Grosso do Sul usava chapéus, mas menos da metade usava botas, máscaras, luvas e roupas impermeáveis (RECENA et al., 2006).

Cabe ressaltar que, segundo a Portaria no 11.357/2020 entre os equipamentos de proteção individual mais usados no meio rural, certificados e aprovados pelo MT, estão as máscaras protetoras, os óculos, luvas impermeáveis, chapéu impermeável de abas largas, botas impermeáveis, macacão com mangas compridas e avental impermeável (BRASIL, 2020). Os agricultores alegam, em alguns estudos, que o uso inadequado e a não utilização dos equipamentos de proteção se dá por serem inadequados às condições climáticas e de trabalho, desconfortáveis, dificultando a respiração, além de serem desprezados devido à incerteza quanto à eficácia destes equipamentos (SCHMIDT; GODINHO, 2006; VEIGA et al., 2007; EMER et al., 2009). Além disso, destaca-se a classe socioeconômica, baixa escolaridade, falta de suporte técnico e não leitura dos rótulos (PETARLI et al., 2019).

O uso de EPIs faz parte da rotina diária de muitos trabalhadores, como medida protetiva, buscando reduzir ou atenuar os riscos à saúde e à segurança dos trabalhadores (RIBEIRO JUNIOR et al., 2020; PETARLI et al., 2019; TINOCO et al., 2019). No entanto, os EPIs não são projetados para eliminar os riscos, e a maioria desses produtos comercializados não são validados, não garantindo a segurança total em seu uso e manuseio (MEIRELLES; VEIGA; DUARTE, 2016; SILVERIO et al., 2020).

Referente aos itens do questionário de "Atitudes tomadas em casa", como cuidados com a higienização de frutas e verduras antes de comer, roupas de trabalho, e a própria casa em si, foi verificado que as gestantes relatam atitudes seguras. O mesmo ocorreu quanto as "Atitudes prejudiciais para o feto", que incluía questões sobre fumar cigarros, comer frutas sem lavar, tomar bebidas alcoólicas e usar inseticidas em casa e no trabalho. A importância de saber sobre 
as atitudes das gestantes com relação à saúde materno-infantil é bem apontada no estudo de Camargo (2010), com a constatação de que a atividade agrícola e a consequente exposição a agrotóxicos podem estar relacionadas ao aparecimento de defeitos congênitos na população infantil, e no estudo de Chrisman (2008), o qual evidenciou a exposição ambiental aos agrotóxicos por mulheres gestantes e os danos decorrentes, durante a gravidez e no pós-parto, em pequenas comunidades rurais do Brasil.

O Sistema de Informação de Nascidos Vivos, do MS, verificou no Paraná, maior associação entre o uso de agrotóxicos e malformações congênitas do sistema circulatório em municípios mais expostos a agrotóxicos do estado, entre 1994 e 2014 (SILVA DUTRA; FERREIRA, 2017). Em um estudo realizado em uma cidade no Paraná demonstrou associação entre pais expostos a agrotóxicos e malformações craniofaciais, como a Fissura Labiopalatina, e outro realizado no estado do Mato Grosso, que apresentou maior ocorrência de malformações congênitas entre filhos de mães expostas a pesticidas durante o período perinatal do que entre outras mães (COSTA; TAKESSHITA; JACOBUCCI FARAH, 2013; OLIVEIRA, et al., 2014).

As gestantes desse estudo também demonstraram ter clareza sobre os itens de "Responsabilidade para uso seguro dos agrotóxicos, ler rótulo das embalagens" e "Responsabilidade para uso seguro dos agrotóxicos, reutilização das embalagens", com respostas acima da média, que caracterizam atitudes seguras e que demonstra responsabilidade quanto ao uso de agrotóxicos por grande parte das gestantes, bem como, seu conhecimento sobre não reutilizar as embalagens de produtos após seu uso.

Fatores como analfabetismo ou nível baixo de escolaridade são determinantes presentes nos agricultores e que repercutem nas práticas sobre o uso seguro dos agrotóxicos, uma vez que torna as informações contidas nas etiquetas do produto de difícil compreensão, contribuindo para o escasso conhecimento sobre a periculosidade e toxicidade do produto (VEIGA et al., 2007; PETARLI et al., 2019). Esse não cuidado com os produtos pode gerar os casos de intoxicação da gestante, podendo gerar prejuízos ao feto.

A destinação final das embalagens vazias de agrotóxicos é um procedimento complexo que requer a participação efetiva de todos os agentes envolvidos na fabricação, comercialização, utilização, licenciamento, fiscalização e monitoramento das atividades relacionadas com o manuseio, transporte, armazenamento e processamento dessas embalagens. No Brasil, a Lei $n^{\circ}$ 7.802/1989 regulamenta sobre o uso dos produtos agrotóxicos, desde a sua produção e comercialização até o destino final dos resíduos e embalagens, entre outras providências. Incluiu desde 2000, no Art. 19, a obrigatoriedade das empresas produtoras e comercializadoras de agrotóxicos, pela responsabilidade da destinação das embalagens vazias 
dos produtos, após a devolução pelos usuários. A partir disso, o Governo, em conjunto com as iniciativas privadas, vem trabalhando num programa nacional para o destino final das embalagens. Essas parcerias estabelecidas e os convênios firmados com empresas e entidades permitiram a implantação de diversas centrais de recebimento de embalagens no Brasil, que hoje ajudam a reduzir o número de embalagens abandonadas na lavoura, estradas e às margens de mananciais d'água (ANDAV, 2000).

Em estudos nacionais, foi constatada a alta aderência ao programa de coleta de embalagens de agrotóxicos vazias, em estados como São Paulo e Rio Grande do Sul, onde os agricultores devolvem as embalagens vazias, porém, no Mato Grosso do Sul, ainda existe queima e extravio das embalagens, indicando que essas práticas seguras não são totalmente realizadas pelos agricultores (FARIA; ROSA; FACCHINI, 2009; BIGATÃO, 2009; RIBEIRO et al., 2012).

As "Práticas" para o uso seguro dos agrotóxicos referem-se à informação sobre o uso ocupacional e doméstico, uso de equipamento de proteção individual e uso de outras precauções seguras durante e depois da utilização dos agrotóxicos. As práticas de precaução, em casa e no trabalho, como formas efetivas de prevenir a exposição a agrotóxicos, refere-se ao não uso de sapatos e roupas de trabalho dentro de casa, a lavagem e o armazenamento dessas roupas separadas de outras roupas da família, bem como, o armazenamento das embalagens de agrotóxicos distantes da casa onde vivem, e uso de equipamento de proteção e os resultados revelam práticas seguras pelas gestantes deste estudo.

Em estudo anterior a este, a respeito da tradução do questionário CAP em gestantes expostas a agrotóxicos, verificou-se que quase a totalidade de gestantes (80\%) demonstrou reconhecer as práticas seguras de cuidados frente aos produtos, assim como, as práticas seguras em casa (CASSOL; MAGNI, 2015).

Goldman e coautores (2004) sugeriram em seu estudo que muitas gestantes trabalhadoras não adotam comportamentos que possam minimizar exposição a agrotóxicos para si ou suas famílias, como por exemplo, não utilizar roupas e sapatos de trabalho dentro de casa, contudo, também não foi possível verificar nesse estudo se as gestantes haviam recebido treinamento de segurança ou outros. Os resultados deste estudo sugerem que as intervenções devem ser implementadas com trabalhadores rurais e suas famílias para reduzir comportamentos potencialmente perigosos de exposição a agrotóxicos (GOLDMAN et al., 2004). Além disso, é importante ter presente que o trabalho na agricultura envolve outros riscos danosos a saúde no geral, mas que os agrotóxicos, mesmo que isolados são capazes de danos irreversíveis, como comprovado no estudo de Cassol, Kanawasa, Szekut e Lopes (2020), de 
que os agrotóxicos podem causar alterações do sistema auditivo periférico, mesmo que não haja presença de ruído no local de trabalho.

No estudo de Pasiane e colaboradores (2012), os agricultores relatam que observam a direção do vento para a escolha do momento certo de aplicação do agrotóxico. Isto é uma prática desenvolvida a partir de um conhecimento cultural adquirido. Estas práticas são importantes para minimizar a exposição humana em regiões tropicais onde as temperaturas atmosféricas mais altas aumentam a volatilidade dos produtos químicos e, consequentemente, aumentando a predisposição para inalação e absorção dérmica, no entanto, não garantem a segurança do trabalhador, ou de populações próximas (SILVA et al., 2005).

O uso de EPIs ainda não é uma prática regular de prevenção e cuidados na exposição por mulheres, e por esse motivo ainda apresentem sintomas de envenenamento (BRUST et al., 2019).

Apenas o item "Práticas referentes a animais domésticos" obteve média de acertos baixa. Isso pode ser justificado pelo fato das gestantes não associarem que os produtos utilizados no ambiente doméstico para o controle de baratas, mosquitos, roedores e na jardinagem amadora podem ser tão tóxicos, quanto os produtos utilizados na lavoura. No entanto, é importante o esclarecimento de que os agrotóxicos são produtos químicos utilizados para combater pragas, também são chamados de praguicidas, pesticidas, defensivos agrícolas, agroquímicos ou biocidas. Sua utilização pode ser tanto na agricultura, para controlar insetos, fungos, ácaros, ervas daninhas, dentre outros; na pecuária: no controle de carrapatos, pulgas, mosca-do-chifre, e outros, e também no domicílio para matar pulgões e larvas em plantas, eliminar cupins, ratos, baratas, algas em piscinas, e carrapatos e pulgas em animais. Todos os agrotóxicos são potencialmente perigosos, podem causar danos à saúde de pessoas, animais e ao meio ambiente (SIQUEIRA; KRUSE, 2008; PARANÁ, 2018; CASSOL; KANAZAWA; SZEKUT; LOPES, 2020).

\subsection{ANÁLISE DAS ETAPAS DE VALIDAÇÃO DO QUESTIONÁRIO}

O avanço na área da saúde, e a prática baseada em evidências, faz emergir a necessidade constante de medidas válidas e confiáveis, com instrumentos calibrados para medir construções aplicadas de acordo com os padrões. Os instrumentos utilizados na pesquisa e no cuidado avaliam aspectos mentais, sociais e físicos e têm como objetivo alcançar uma boa saúde e tomar decisões sobre cuidados e políticas de saúde (CANO; HOBART, 2011; COLUCI; ALEXANDRE; MILANI, 2015). 
É importante o desenvolvimento de instrumentos para fins de medir a morbidade ou aspectos físicos, entretanto, esse processo é menos complexo que a elaboração de instrumentos que avaliam construções ou características relacionadas ao comportamento humano. Esse fato tem motivado a adaptação de instrumentos previamente construídos, adequados às especificidades culturais, sociodemográficas ou clínicas da população estudada (GUILLEMIN; BOMBARDIER; BEATON, 1993; FLECK, 2000; CURADO; TELES; MARÔCO, 2014).

No caso dos estudos que propõe medir condições subjetivas com instrumentos construídos ou adaptados, é necessária manter alta qualidade metodológica, tanto na definição quanto na mensuração do construto de interesse, a fim de obter conclusões confiáveis, uma vez que esse instrumento deve oferecer resultados clinicamente úteis, significativos e interpretáveis, e propriedades psicométricas como validade e confiabilidade (PASQUALI, 2009; MOKKINK et al., 2010a; 2010b; CANO; HOBART, 2011). Além disso, a capacidade de resposta do instrumento também deve ser avaliada (PASQUALI, 2009).

No Brasil, o número de adaptações de instrumentos elaborados e validados em outras culturas e o número de construções de novos questionários têm aumentado significativamente, apoiados por instituições educacionais internacionais e o financiamento de agências governamentais, uma vez que, grande parte dessas pesquisas, são destinadas a melhoria da condição de saúde da população geral (ABREU et al., 2015; PRAXEDES, et al., 2017).

Nesse estudo, o questionário CAP passou pelas etapas de validação de instrumento sugeridas na literatura que envolvem a Confiabilidade por meio da testagem da Estabilidade, Consistência Interna e Equivalência, e Validade de Conteúdo, Validade de Critério e Validade de Constructo com a técnica de grupos conhecidos (CRONBACH; 1951; SHMIDT; SCHAEFER, 2003; ROACH, 2006; SALMOND, 2008; PASQUALI, 2009; 2010; 2011; KESZEI; NOVAK; STREINER, 2010; STREINER; KOTTNER, 2010; HEALE; TWYCROSS, 2015; WYND; COLUCI; ALEXANDRE; MILANI, 2015).

Os instrumentos de medida integram a prática clínica e a pesquisa em diferentes áreas do conhecimento, e a avaliação de sua qualidade é fundamental para a seleção de instrumentos que forneçam medidas válidas e confiáveis àquela população, respeitando suas particularidades (OLIVEIRA et al.,2018). No entanto, é importante destacar que a Confiabilidade e a Validade não são propriedades fixas e, portanto, variam de acordo com as circunstâncias, população, tipo e finalidade do estudo (PASQUALI, 2011; SOUZA; ALEXANDRE; GUIRARDELLO, 2017).

\subsubsection{Análise da Confiabilidade}


A confiabilidade, também denominada fidedignidade, é um dos critérios principais de qualidade de um instrumento. Essa análise refere-se ao quão estável, consistente ou preciso é o instrumento, e aborda a capacidade em reproduzir um resultado de forma consistente no tempo e no espaço, ou a partir de observadores diferentes, indicando aspectos sobre coerência, precisão, estabilidade, equivalência e homogeneidade (TERWEE et al., 2007). Para essa avaliação, foram realizados os testes de estabilidade, consistência interna e equivalência de uma medida (MARTINS, 2006).

\subsubsection{Análise da Confiabilidade quanto a Estabilidade}

A estabilidade de uma medida é o grau em que resultados similares são obtidos em dois momentos distintos, medindo assim a estimativa da consistência das repetições das medidas (POLIT; BECK, 2011). Para a análise da confiabilidade quanto a estabilidade o instrumento foi aplicado duas vezes com intervalo máximo de 15 dias, segundo indicado pela literatura, uma vez que quando mais prolongado esse tempo, a confiabilidade do teste-reteste tende a diminuir (KESZEI; NOVAK; STREINER, 2010).

Os resultados mostraram que apenas para o domínio "Responsabilidade para uso seguro dos agrotóxicos, ler rótulo das embalagens" o valor do Coeficiente de Correlação Interclasse (CCI- intraclass correlation coefficient - ICC) foi negativo, e para o domínio "Uso de vestimenta adequada no trabalho" o valor foi inferior a 0,7 , sendo que para todos os demais o valor foi superior a 0,7 .

O CCI pode representar a concordância entre várias medidas feita pelo mesmo objeto, dessa forma, ele varia entre 0 e 1 , sendo que quanto mais próximo de 0,0 pior foi a correlação, e quando mais próximo de 1 , melhor. Ou seja, nos domínios analisados nesse questionário, o item "Responsabilidade para uso seguro dos agrotóxicos, ler rótulo das embalagens" não obteve correlação no teste e reteste, e o item "Uso de vestimenta adequada no trabalho" apresentou correlação fraca. Os demais itens apresentaram correlação forte. Esse resultado é favorável ao questionário, uma vez que a análise do ICC é um método que requer que o fator a ser medido permaneça o mesmo nos dois momentos dos testes e qualquer mudança no escore pode ser causada por erros aleatórios (KESZEI; NOVAK, 2010).

Nesse sentido, é importante respeitar o período entre a aplicação do teste e reteste recomendado pela literatura, uma vez que, se o reteste for realizado antes de dois dias é possível que as respostas sejam idênticas a primeira aplicação, o que aumentará o coeficiente de correlação, mas representará uma falsa confiabilidade, e se aplicado acima de 15 dias, o contrário pode ocorrer, produzindo uma confiabilidade baixa do questionário, mas que não 
necessariamente expresse a verdade. Priorizou-se pela aplicação entre 2 e 15 dias, permitindo a média de 7,5 dias, para uma análise mais confiável do parâmetro (BRACHER, 2008; KESZEI; NOVAK; STREINER, 2010).

É importante destacar, que o questionário original em inglês, que motivou esse estudo de validação, não é validado em sua língua de origem (inglês) e por esse motivo, não apresenta testes para comparação (LORENZ et al., 2012).

\subsubsection{Análise da Confiabilidade quanto a Consistência Interna}

Para a análise de confiabilidade quanto à consistência interna, também conhecida por homogeneidade, foram considerados os itens que todos os participantes deveriam preencher, independentemente das respostas das demais questões. Para isso foi calculada a correlação de item total corrigida, o valor do coeficiente Alfa de Cronbach para o instrumento no formato atual, e o valor do Alfa de Cronbach para o instrumento se o item fosse excluído. O Alfa de Cronbach do instrumento considerando 62 itens e 73 sujeitos foi de 0,906. Os resultados do teste mostram que as correlações corrigidas do item-total foram de fortes a fracas, porém, não houve necessidade de excluir nenhum item, considerando-se que as exclusões afetariam muito pouco a consistência interna do instrumento.

A consistência interna é uma importante propriedade de medida para instrumentos que avaliam um único construto, utilizando, para isso, uma diversidade de itens (TERWEE; BOT; BOER, 2007). Uma estimativa de consistência interna baixa, como apresentado em alguns itens do questionário desse estudo, pode significar que os itens medem construtos diferentes ou que as respostas às questões do instrumento são inconsistentes (KESZEI; NOVAK; STREINER, 2010).

O recomendado para essa análise é o coeficiente alfa de Cronbach, utilizado pela maioria dos pesquisadores, desde a década de 50, para avaliação da confiabilidade, pois ele reflete o grau de covariância entre os itens de uma escala (CRONBACH, 1951; KESZEI; NOVAK; STREINER, 2010; PASQUALI, 2013; STREINER; KOTTNER, 2014). Dessa forma, quanto menor a soma da variância dos itens, mais consistente é considerado o instrumento (PASQUALI, 2013).

Autores sugerem que a consistência interna dos itens deva ser classificada da seguinte forma: valores $\geq 0,9$ são considerados excelentes, $\geq 0,8$ são considerados bons, $\geq 0,7$ são aceitáveis, $\geq 0,6$ são questionáveis, $\geq 0,5$ são pobres, e $\leq 0,5$ são inaceitáveis, embora não exista um limite inferior para o coeficiente. Os valores de alfa de Cronbach encontrados neste estudo foram semelhantes aos preconizados pela literatura (Apêndice 1), com valores considerados 
excelentes, mostrando que o instrumento manteve sua homogeneidade, sinalizando que o instrumento apresenta consistência interna satisfatória (KLEIN et al., 2012). No entanto, essa classificação não é consenso de todos os autores, uma vez que alguns estudos determinem que valores superiores a 0,7 sejam os ideais, algumas pesquisas consideram valores abaixo de 0,70 - mas próximos a 0,60 - como satisfatórios (NUNNALY; BERNSTEIN, 1994; STREINER, 2003; TERWEE; BOT; BOER, 2007). Também é importante destacar que os valores do coeficiente alfa de Cronbach são fortemente influenciados pelo número de itens do instrumento de medida, ou seja, um pequeno número de itens por domínio de um instrumento pode diminuir os valores de alfa, afetando a consistência interna (CORTINA, 1993; SIJTSMA, 2009).

Um estudo internacional que verificou a consistência interna das escalas "Escala de Crenças EBP para Educadores” (EBPB-E), "Escala de Implementação EBP para Educadores” (EBPI-E) e "Cultura Organizacional e Prontidão para Integração em toda a Escola Pesquisa Prática Baseada em Evidências "para Educadores (OCRSIEP-E) o coeficiente alfa de Cronbach mostrou forte consistência interna (CARDOSO et al., 2020).

Em outro estudo, que objetivou analisar as propriedades psicométricas da versão adaptada da Bakas Caregiving Outcome Scale para o português do Brasil, na análise da consistência interna realizada pelo alfa de Cronbach foi de 0,89 , inferior que o estudo apresentado, mas que revela uma medida internamente consistente (COSTA et al., 2020). O mesmo ocorreu na validação do Protocolo Tinnitus Handicap Inventory (THI), um questionário auto-aplicável que avalia a repercussão do zumbido na qualidade de vida dos pacientes, no qual a validade interna foi satisfatória (SCHMIDT et al., 2006).

Outros estudos também corroboram com o encontrado nessa validação, um realizado em uma policlínica universitária, envolvendo médicos, enfermeiros e estagiários, com vistas a validar uma versão em italiano do questionário produzido pela OMS acerca da violência no ambiente de trabalho, obteve também resultados satisfatórios, boa confiabilidade e consistência interna, mostrando ser uma ferramenta útil na avaliação e prevenção da ocorrência de violência no ambiente de trabalho (LA TORRE et al., 2017) e outro analisando as informações levantadas, dados semelhantes sobre validação de tecnologias educativas com índices estatísticos substanciais foram observados. Cita-se, por exemplo, a validação e a confiabilidade de uma escala, aplicada na Turquia, para avaliar a satisfação de estudantes de enfermagem referente à sua educação clínica, que teve variância de 0,93-0,99 na escala alfa de Cronbach, na qual seis fatores foram identificados, com uma variância total de $64 \%$, considerada válida e confiável (LIMA et al., 2017). 
No entanto, pelo fato de algumas terem dado consistência forte e outras fracas, e mesmo realizando a exclusão o não houve alteração da consistência interna, é possível deduzir que devido ao fato do questionário apresentar questões com modalidades diferentes (por exemplo, em algumas eram apresentadas duas alternativas - sim e não - em outras, de 4 a 7 , e outras apresentavam possibilidades dissertativas) não permitindo a elaboração de um padrão de respostas.

Destaca-se que a confiabilidade de um instrumento deve ser sempre discutida em função da população e do propósito do estudo. Um instrumento confiável para um conjunto de situações pode não ter a mesma confiabilidade em circunstâncias diferentes.

\subsubsection{Análise da Confiabilidade quanto a Equivalência}

A análise da confiabilidade para equivalência, que se refere ao grau de concordância entre dois ou mais observadores quanto aos escores de um instrumento, é a maneira mais comum de se avaliar a equivalência de um instrumento. Para isso, o instrumento é preenchido pelos avaliadores, e espera-se que as respostas, ou pontuações obtidas sejam as mesmas (KESZEI; NOVAK; STREINER, 2010; POLIT; BECK, 2011; HEALE; TWYCROSS, 2015). Considerando-se que se tratavam de variáveis qualitativas nominais, utilizou-se o Coeficiente de Concordância de Kappa, uma medida de concordância entre os avaliadores que assume valor máximo igual a 1,00, ou seja, quanto maior o valor de Kappa, maior a concordância entre os observadores. Nessa análise, o valor de Kappa foi de 0,448 o que indica a inexistência de concordância, pois quanto mais próximo o valor de 0,00 , menor é a concordância.

Embora esse critério de corte não seja totalmente consensual na literatura, alguns autores classificam os valores de Kappa da seguinte maneira: $\mathrm{K}<0,4$ é pobre; $\mathrm{K} 0,4 \leq \mathrm{a}<0,75$ é satisfatório a bom; $\mathrm{K} \geq 0,75$ é excelente (FLEISS, 1981). Considerando esse autor, o valor de Kappa obtido nesse estudo foi satisfatório. No entanto, Altman (1991) considera a concordância alta a partir de 0,80 .

Os avaliadores selecionados para essa análise são pesquisadores da área de toxicologia e saúde do trabalhador, que desenvolvem estudos voltados a essa população exposta a agrotóxicos. No entanto, cada um deles possui sua subjetividade, cultura, experiências, e tudo mais que as envolve, não sendo esse mérito da seleção como juiz, mas que possivelmente interferiu nos resultados dessa análise, uma vez que, ao responder um questionário, vivencias e conceitos pessoais podem transcender a opinião. 


\subsubsection{Análise da Validade}

A validação é o processo de examinar a precisão de uma determinada predição ou inferência realizada a partir dos escores de um teste (PASCOALI, 2009). Considerada uma investigação, o processo de validação não se esgota, ao contrário, pressupõe continuidade e deve ser repetido inúmeras vezes para o mesmo instrumento, pois o que valida-se não é propriamente o teste, mas a interpretação dos dados decorrentes de um procedimento específico. A cada aplicação de um instrumento, pode corresponder, portanto, uma interpretação dos resultados (RAYMUNDO, 2009).

A validade de um teste começa no momento em que se pensa em construí-lo e subsiste durante todo o processo de elaboração, aplicação, correção e interpretação dos resultados. A validade pode ser definida como "o grau em que todas as evidências acumuladas corroboram a interpretação pretendida dos escores de um teste para os fins propostos" (PASQUALI, 2013).

Essa medida refere-se ao fato do instrumento medir exatamente o que se propõe a medir, e para isso foram analisados três tipos principais de validade: validade de conteúdo, validade de critério e validade de constructo.

\subsubsection{Análise da Validade de Conteúdo}

A validade de conteúdo refere-se ao julgamento sobre o instrumento, ou seja, se ele realmente cobre os diferentes aspectos do seu objeto e não contém elementos que podem ser atribuídos a outros objetos. Ela não é determinada estatisticamente, mas resulta do julgamento de diferentes examinadores especialistas, que analisam a representatividade dos itens em relação às áreas de conteúdo e à relevância dos objetivos a medir.

A análise de juízes ou análise de conteúdo é baseada no julgamento realizado por um grupo de juízes experientes na área, a qual caberá analisar se o conteúdo está correto e adequado ao que se propõe (MOURA; BEZERRA; OLIVEIRA; DAMASCENO, 2008). A análise da validade de conteúdo pode fornecer informações sobre a representatividade e clareza de cada item com a colaboração de especialistas, porém existem limitações nos estudos de validade de conteúdo que precisam ser observadas, visto que a análise dos especialistas é subjetiva e, por conseguinte, podem existir distorções nos estudos (RUBIO et al., 2003). Nesse estudo, os juízes foram selecionados por desenvolverem pesquisas relacionadas a temática deste estudo, e convidados a participar espontaneamente. 
Para analisar a validade de conteúdo, que se refere ao grau em que o conteúdo de um instrumento reflete adequadamente o construto que está sendo medido, utilizou-se o Índice de Validade de Conteúdo (IVC) (POLIT, 2015). Três juízes analisaram cada questão atribuindo uma pontuação de 1 a 4, em que: 1 = item não claro; 2 = item pouco claro; 3 = item bastante claro; e 4 = item muito claro (COLUCI; ALEXANDRE; MILANI, 2015). Foi contabilizada a contagem do número de questões com notas três e quatro, e total da contagem foi dividido pelo número total de questões avaliadas. O cálculo foi realizado para cada juiz individualmente, e para o total de juízes. A Tabela 12 mostra que o IVC foi entre 0,94 e 0,97 para os juízes individuais, e de 0,96 para o total de juízes, o que demonstrou concordância aceitável entre os membros do comitê de especialistas, representando que os itens avaliados do questionário são medidas válidas e precisas (POLIT; BECK, 2006).

Pesquisas desenvolvidas com o tema da tecnologia educacional sobre a violência contra a mulher, apresentou na análise do IVC valor superior a 0,92 (SOUSA et al., 2020). Em outra pesquisa desenvolvida em Natal-RN com tema semelhante sobre um curso de suporte avançado de vida à distância, alcançou um IVC global de 0,94 (LA TORRE et al., 2017). Em contrapartida, em pesquisa realizada em Fortaleza, em que se analisou uma cartilha para prevenção da transmissão vertical do HIV, atingiu-se IVC global de 0,87 (COSTA et al., 2018).

Em estudo nacional, que validou o Protocolo de avaliação do frênulo da língua para bebês, a concordância entre os juízes foi de 100\%, percentual acima do estabelecido na literatura para um instrumento ser considerado validado, e demonstrou que o referido protocolo foi considerado uma medida válida e precisa para todos os itens avaliados (WYND; SCHMIDT; SCHAEFER, 2003; HERMIDA; ARAÚJO, 2006; SIQUEIRA; KRUSE, 2008; ALEXANDRE; COLUCI, 2011).

\subsubsection{Análise da Validade de Critério}

A validade de critério, segundo Pasquali (2009) é a correlação existente entre a medida avaliada em relação à outra medida ou instrumento que serve como critério de avaliação, que possui atributos iguais ou semelhantes (PASQUALI, 2009). Ela consiste na relação entre pontuações de um determinado instrumento e algum critério externo (KIMBERLIN; WINTERSTEIN, 2008).

Este critério deve consistir em uma medida amplamente aceita, com as mesmas características do instrumento de avaliação, ou seja, um instrumento ou critério considerado “padrão-ouro” (KESZEI; NOVAK; STREINER, 2010). Na situação de não haver um critério 
estabelecido que seja fiel a proposta, se o instrumento proposto ou a ser validado, mede o que pretende medir, então seus resultados devem concordar e corresponder com os resultados do 'padrão-ouro' ou do critério escolhido (ROACH, 2006).

$\mathrm{Na}$ validade de critério há um grau de correlação entre os escores de um teste e outras medidas do desempenho (critério) obtidas independentemente ou simultaneamente ao teste, chamados validade preditiva ou concorrente. Quando o instrumento e o critério são aplicados simultaneamente, fala-se de validade concorrente; quando o critério é avaliado no futuro, falase de validade preditiva (ROACH, 2006; POLIT; BECH, 2011).

No caso desse estudo, para a análise da validade de critério, os escores dos domínios de cada construto foram comparados entre dois grupos independentes constituídos a partir das respostas para questões que analisam o mesmo construto. Após a aplicação do questionário, foi realizada a testagem de três questões a fim de confirmar a validade de critério (WATKINS et al., 2001; PASCOALI, 2009). Para isso, os participantes foram orientados a responder "sim" ou "não" para as perguntas: a) "Você acredita que tem conhecimento adequado sobre os efeitos dos produtos agrotóxicos? "; b) "Você acredita que tem atitudes adequadas frente aos agrotóxicos?", e c) "Você acredita que possui praticas seguras sobre os agrotóxicos?".

Os resultados apontaram que não houve diferença ou associação entre as questões critério, e os domínios ou perguntas do questionário. No caso do questionário CAP, não foi encontrado um questionário padrão-ouro para comparação. O questionário original em inglês (KAP) não é validado, e por esse motivo não apresenta as análises para tal comparação.

É possível que o critério estabelecido, por apresentar perguntas diretas com respostas objetivas de "sim" e "não", não tenha favorecido, sendo um critério fraco de comparação, uma vez que limita as respostas das gestantes. Uma alternativa a ser pensada é criar uma escala que permita mais flexibilidade nas respostas. Outra situação, também se acredita que isso tenha sido uma reflexão após ter respondido todas as questões do questionário e ter repensado acerca de seu conhecimento, atitudes e práticas.

$\mathrm{Na}$ literatura, se verifica situações semelhantes, como foi o caso da validação do "Protocolo de Avaliação do Frênulo Lingual em Bebês", que na comparação da validade de critério, como não foi encontrado protocolos totalmente validados, considerados padrão-ouro na literatura, a análise da validade de critério, foi realizada por meio da comparação com o outro protocolo, que avaliava questões semelhantes (VENANCIO et al., 2015; MARTINELLI et al, 2015).

Em outro estudo fonoaudiológico, que pretendeu a validação do "Protocolo de avaliação miofuncional orofacial MBGR para adultos com disfunção temporomandibular com 
deslocamento de disco com redução", foi utilizado como padrão para a validade concorrente, o "Protocolo de Avaliação Miofuncional Orofacial com Escores - AMIOFE" (FELÍCIO; FERREIRA, 2008), uma vez que esse protocolo foi validado na mesma população com sensibilidade e especificidade de 80\% (FELÍCIO; MEDEIROS; OLIVEIRA-MELCHIOR, 2012). O resultado da comparação entre os protocolos MBGR e AMIOFE mostrou que a porcentagem de concordância foi maior do que a discordância e houve correlação negativa significante para todos os aspectos aos quais foi possível aplicar o teste. A variação da força da correlação de média a forte encontrada para os aspectos considerados na presente pesquisa foi justificada pelas diferenças entre os itens e o modo de avaliação dos dois protocolos (Tabela 13, 14 e 15) (BUENO; ROSA; GENARO; BERRETIN-FELIX, 2020).

Outra pesquisa, sobre a validade de critério concorrente do protocolo WHOQOL-HIV Bref para avaliação da qualidade de vida, foi verificada por meio das correlações entre os escores dos domínios do questionário com a auto percepção da qualidade de vida e da saúde, e para determinar a validade de critério divergente foram utilizadas as correlações entre os escores dos domínios do WHOQOL-HIV Bref e os escores do Inventário de Depressão (BECK; STEER, 1996). Nesse caso, embora sejam constructos diferentes, apresentam-se correlacionados inversamente uma vez que há a hipótese de que os indivíduos com alto escores de qualidade de vida apresentem baixos escores de sintomas depressivos (SILVEIRA et al., 2019).

Esses estudos apontam, de maneira geral, que há outras possibilidades de determinar a validade de critérios, indicando novas possibilidades para testar a validade nesse questionário.

\subsubsection{Análise da Validade de Construto}

Por definição, construtos são traços, aptidões ou características supostamente existentes e abstraídos de uma variedade de comportamentos que tenham significado educacional (ou psicológico). Assim, fluência verbal, rendimento escolar, aptidão mecânica, inteligência, motivação, agressividade, entre outros, são construtos (RAYMUNDO, 2009). No caso deste estudo, são considerados construtos: conhecimento, atitudes e práticas.

A validade de construto, também denominada validade intrínseca, validade fatorial ou validade aparente, permite determinar se o instrumento realmente mede aquilo a que se propõe medir (MARTINS, 2006; PASQUALI, 2009). As evidências necessárias para esse tipo de validação são obtidas fazendo-se uma série de estudos inter-relacionados, por meio de testes estatísticos, das construções teóricas sobre a relação entre as variáveis a serem medidas 
(RAYMUNDO, 2009). Quanto mais abstrato o conceito, mais difícil é estabelecer a validade de construto (POLIT; BECK, 2011).

Para constatar o construto, são realizadas várias provas, que precisam ser analisadas em todos os seus detalhes. Esse tipo de validação visa a detectar, entre outros aspectos, quais as variáveis com as quais os escores do teste se correlacionam, quais os tipos de itens que integram o teste, o grau de estabilidade dos escores sob condições variadas e o grau de homogeneidade (se o teste mede um único traço ou se, ao contrário, mede traços diversos) do teste, com vistas a ter elementos que possam esclarecer o significado do instrumento (RAYMUNDO, 2009).

No entanto, a validação de construto não se limita a validar um teste, tendo alcance bem mais amplo, centrando-se o seu objetivo na validação da teoria em que se apoiou a construção do instrumento. O trabalho de validação de um construto é uma pesquisa científica empírica, porque, definidos os construtos que seriam responsáveis pelo desempenho no teste, o avaliador passa a formular hipóteses sobre a teoria de construtos e a testá-las empiricamente (RAYMUNDO, 2009; POLIT; BECK, 2011).

No caso deste estudo, a validade de construto é fundamental, uma vez que ele auxilia o pesquisador a determinar e entender melhor as questões cognitivas e psicológicas que estão sendo medidas pelo teste (PASQUALI, 2009). Ou seja, buscou-se verificar qual o conhecimento, atitudes e práticas de gestantes expostas a agrotóxicos sobre esses produtos.

A validade de construto é subdividida em três tipos: teste de hipóteses, validade estrutural ou fatorial e validade transcultural (MOKKINK et al., 2010; POLIT, 2015).

No teste de hipóteses, uma das estratégias dessa testagem é a técnica de grupos conhecidos, na qual grupos diferentes de indivíduos preenchem o instrumento de pesquisa e em seguida, os resultados dos grupos são comparados (ROACH, 2006; POLIT; BECK, 2011). Nesse estudo, para essa análise, as gestantes do Grupo Expostas foram comparadas as gestantes do Grupo Não Expostas a fim de verificar diferenças nos escores dos domínios dos construtos de conhecimento, atitudes e práticas do Questionário CAP. A análise permitiu inferir que os grupos foram homogêneos para as variáveis idade, nacionalidade, estuda atualmente e renda familiar. A análise dos escores das perguntas dos construtos conhecimento, práticas e atitudes do Questionário CAP demonstrou que houve diferença estatística entre os grupos de gestantes, e apenas no domínio "Atitudes em casa" o Grupo Expostas apresentou menor escore que o Grupo Não Expostas. Isso identifica que as gestantes do Grupo Não Expostas têm mais cuidados com a higienização de frutas e verduras antes de comer, com suas roupas de trabalho, e a própria casa em si. Sobre isso, ao se analisar questões referente a renda familiar e nível de 
escolaridade, que poderiam ser fatores que interferissem nessa questão, se observa que nesse estudo, essas variáveis são homogêneas (Tabela 17).

Entretanto, o Grupo Expostas apresentou maiores escores que o grupo Não Expostas nos domínios "conhecimento sobre população de risco", "conhecimento dos sintomas de intoxicação", "atitudes prejudiciais para o feto", "responsabilidade para uso seguro dos agrotóxicos, ler rótulo das embalagens" "responsabilidade para uso seguro dos agrotóxicos, reutilização das embalagens", "uso de agrotóxicos e cuidados", "práticas de precaução", “práticas referentes a animais domésticos". É possível que, devido ao fato dos agrotóxicos não serem uma realidade próxima das gestantes não expostas, elas não tenham preocupação, ou conhecimento sobre o assunto, e talvez esses assuntos nunca tenham sido discutidos no ambiente em que vivem. Com as gestantes expostas, é o contrário; embora grande maioria delas não tenha tido instrução sobre o uso seguro e cuidado com os produtos, esse tema faz parte da vivência delas, e indiretamente está sendo comentado pelos vendedores de produtos, agrônomos, representante sindicais, e pelos próprios familiares, uma vez que há um senso comum e generalista de que o "veneno faz mal".

O Teste de Hipóteses também foi utilizado na validação do software denominado $D$ station, para análise das curvas de deformação cardíaca, e indicou equivalência (SOUZA et al., 2020). Gomes e colaboradores (2018) utilizaram o teste de hipóteses com grupos contrastados para a validação do construto da escala Autoeficácia e nível de controle de asma de seus filhos: versão brasileira, confirmando as hipóteses levantadas pelo estudo. Outro estudo, que pretendeu avaliar a validade transcultural do Demand-Control Questionnaire proposto para medir as tensões de trabalho, comparando o questionário sueco original com a versão brasileira, mostrou por meio do teste de hipóteses que os trabalhadores com diploma universitário obtiveram pontuações mais altas em critério de habilidade e autoridade de decisão e aqueles com altos níveis de Suporte Social no Trabalho apresentaram pontuações mais baixas em demandas psicológicas e pontuações mais altas em autoridade de decisão (HOKERBERG, 2014).

A Validade Estrutural ou Fatorial, fornece ferramentas para avaliar as correlações em um grande número de variáveis, definindo os fatores, ou seja, as variáveis fortemente relacionadas entre si (HAIR et al., 2006; POLIT; BECK, 2011). Nesse estudo, as características do instrumento não permitiram a análise fatorial, pois o Questionário CAP apresenta variação nos modelos de questões: possui questões com alternativas "sim" e "não", com escala likert e dissertativa. Outra particularidade do questionário é que a resposta de uma questão, se sim ou não, interfere diretamente se irá responder a próxima questão ou seção do questionário. Essas singularidades dificultam a analise fatorial, uma vez que não consegue categorizar os dados. 
Situação semelhante a essa ocorreu em estudo recentemente publicado, sobre a Adaptação transcultural do Amsterdam inventory for auditory disability and handicap para o português do Brasil, que considerou que a ausência da análise fatorial foi um fator limitante nos resultados (ZANCHETTA et al., 2020). Os autores referem que esta análise foi realizada no estudo original e na versão sueca, no entanto, o número da amostra de Pt-AIADH não permitiu o cálculo no estudo brasileiro (KRAMER, KAPTEYN, FESTEN, TOBI, 1995; HAIR, et al., 2006). No entanto, apesar de faltar uma análise fatorial, os autores consideraram que a ausência não prejudicou os resultados obtidos nas medições das demais variáveis do construto, que são bastante satisfatórias (FELDT; CHARTER, 2003).

A Validade Transcultural diz respeito à medida em que as evidências suportam a inferência de que o instrumento original e um adaptado culturalmente são equivalentes (POLIT, 2015). Por exemplo, um instrumento que avalia a satisfação no trabalho e que foi traduzido e adaptado para um outro contexto cultural, deve possuir um desempenho similar ao da versão original (CHIN, 1999).

Essa etapa foi realizada em estudo anterior, realizado por Cassol e Magni (2015), que teve por objetivo traduzir, adaptar e desenvolver o estudo normativo preliminar do Questionário para a língua portuguesa. No referido estudo o instrumento CAP - Conhecimento, Atitudes e Práticas, originalmente em inglês KAP (Knowledges, Attitudes and Practices - LORENZ et al., 2012), foi traduzido para o português brasileiro, analisado por juízes de áreas relacionadas ao objeto do estudo, permitindo a revisão e adequação dos termos; na sequência foi aplicado em um grupo piloto, a fim de realizar a análise semântica e adaptação transcultural de termos. Após a adequação, o instrumento foi retrotraduzido para o inglês. A partir dos resultados foi possível verificar que esse instrumento foi coerente e satisfatório para o levantamento do conhecimento, atitudes e práticas de gestantes brasileiras em relação aos agrotóxicos. Nesse estudo, verificou-se associações significativas entre o conhecimento e a fase de gestação, sendo que quanto mais tempo de gestação, maior foi o conhecimento sobre os riscos à exposição dos agrotóxicos, bem como a tomada de atitudes e práticas seguras durante o período gestacional, em casa e no trabalho.

Em um estudo nacional, sobre a adaptação transcultural do inventário de Amsterdã para deficiência auditiva e deficiência para o português brasileiro, os autores demonstraram a viabilidade do processo de tradução e a adaptação cultural do instrumento, bem como a sua aplicabilidade, resultando na versão em português do inventário de Amsterdã para deficiência auditiva e deficiência (ZANQUETTA et al., 2020). Outro estudo, realizou a tradução e adaptação do instrumento Crenças e Atitudes sobre Prevenção de Perdas Auditivas para o 
português do Brasil (BRAMATI et al., 2012), e na análise das questões de validação, como o construto, e os resultados produziram valores que dão confiança ao uso do respectivo instrumento.

Nesse estudo, realizou-se a validação do Questionário CAP em gestantes expostas aos agrotóxicos, por meio da confiabilidade e da validade de conteúdo, critério e construto. $\mathrm{O}$ estudo, desenvolvido em duas regionais de saúde do Estado do Paraná, não contou efetivamente com a totalidade de gestantes expostas, que expressariam a realidade cultural das regiões. Outra limitação é sobre as características do questionário, que por não seguir um padrão, não permitiu análises importantes, como a análise fatorial.

Por outro lado, o número significativo de gestantes que participaram do estudo, e o cumprimento de todas as etapas de confiabilidade e validade, permitiu a obtenção de dados confiáveis e a inferência de que o instrumento é valido para aplicação em populações brasileiras.

Outro viés a ser destacado, é que apesar dos resultados favoráveis de confiabilidade e validade, indicando a possibilidade de utilização deste Questionário CAP para levantamento do Conhecimento, das Atitudes e das Práticas de gestantes agricultoras no Brasil, a sua aplicação em forma de entrevista, com a presença das agentes comunitárias de saúde ou outro profissional da saúde pode ter gerado algum constrangimento, podendo resultar em alguma influência nas respostas, principalmente acerca de atitudes e práticas tomadas em casa.

Apesar de não ser confirmadas as evidências de que as práticas inseguras relacionadas aos agrotóxicos estejam associadas ao aumento da exposição da população brasileira a esses produtos, é possível que seja esse o principal motivo da ocorrência do aumento das alterações geradas por esses comportamentos de risco, no entanto, seriam necessárias medidas reais de exposição para confirmar essa hipótese. Esse não foi o foco deste estudo, mas as respostas obtidas a partir da aplicação deste instrumento podem ser úteis para futuras intervenções.

Pesquisas futuras devem ter como objetivo desenvolver instrumentos mais homogêneos e reduzidos, que facilitem a aplicação em um número ainda maior de sujeitos, e a análise completa da validação. Outro foco de interesse relacionado ao tema, seria a investigação dos homens, companheiros dessas gestantes, residentes do campo, quanto aos seus conhecimentos, atitudes e práticas frente aos produtos, no que diz respeito a preocupação com a gestação, uma vez que essa não deve ser uma preocupação única da mulher.

Os efeitos negativos dos agrotóxicos em gestantes e seus recém-nascidos merecem atenção das políticas públicas na área de saúde, pois conforme visto, pesquisas realizadas em vários países comprovam intercorrências na gravidez e na saúde do feto. As pesquisas 
científicas têm justamente a função de apresentar situações específicas para que, com medidas públicas eficazes, possam deixar de causar problemas à população.

Esse estudo pode ser um caminho inicial no entendimento da realidade das gestantes, e pode ser considerado um guia norteador de futuras práticas e ações voltadas ao cuidado da mulher exposta aos agrotóxicos. A validação das ferramentas de avaliação de conhecimentos, atitudes e práticas ajudará a desenvolver programas úteis e eficientes. 



\section{7- Conclusão}





\section{CONCLUSÃO}

O presente estudo atingiu o objetivo proposto em relação à análise de confiabilidade e validação do questionário CAP - Conhecimento, Atitudes e Práticas de gestantes expostas a agrotóxicos. A análise desenvolvida no presente estudo indicou que as propriedades psicométricas da adaptação transcultural da versão brasileira da escala são consistentes e adequadas para aplicação no Brasil, o que permite a recomendação da aplicação do instrumento em contexto nacional. É importante que a versão validada do questionário seja aplicada em outros contextos de pesquisa e regiões do Brasil, a fim de compreender as características culturais de cada região.

A análise dos resultados do presente estudo permitiu concluir que: a) a população do estudo foi caracterizada por gestantes jovens, brasileiras, em final de gestação, alfabetizadas, e com renda média familiar entre um e dois salários mínimos. Mais da metade encontrava-se trabalhando no momento da entrevista, e aproximadamente um quarto delas trabalham envolvidas na agricultura. A maioria das gestantes utilizam o SUS para realizar o pré-natal; b) de maneira geral, as gestantes desse estudo apresentaram nível adequado de conhecimento, atitudes e práticas frente aos produtos agrotóxicos; c) o instrumento demonstrou boa Confiabilidade quanto a Estabilidade, e satisfatório quanto a Consistência Interna e Equivalência; d) a Validade de conteúdo do Questionário CAP por meio da avaliação de juízes demonstrou concordância aceitável, enquanto que e) a Validade de critério do Questionário CAP por meio de critério estabelecido, não apresentou associação; f) na análise da Validade de construto do Questionário CAP por meio da técnica de grupos conhecidos, demonstrou homogeneidade nas variáveis idade, nacionalidade, estuda atualmente e renda familiar, e o Grupo Exposta apresentou escores maiores que o grupo controle, exceto no item "Atitudes em casa".

Sendo assim, o Questionário CAP para gestantes expostas a agrotóxicos foi validado para identificação do conhecimento, atitudes e práticas nessa população, envolvendo a validade de conteúdo, de critério e de construto, a confiabilidade, os índices de Estabilidade, Consistência Interna e Equivalência. 



\section{Referências}





\section{REFERÊNCIAS}

AARONSON, N; et al. Assessing health status and quality-oflife instruments: attributes and review criteria. Qual Life Res., v.11, n.3, p. 193-205, 2002.

ABRAMOVAY, M.; DA SILVA, R. As relações de gênero na Confederação Nacional de Trabalhadores Rurais (Contag). En M. Da Rocha (ed.) Trabalho e gênero: mudanças, permanências e desafios (pp. 347-366). São Paulo: ABEP, NEPO/ Unicamp e Cedeplar/UFMG. 2000.

ABREU, I.S., et al. Children and adolescents with chronic kidney disease in haemodialysis: perception of professionals. Rev Bras Enferm., v. 68, n. 6, p. 1020-6, 2015.

AGROANALYSIS. Centro de Agronegócio, Faculdade Getúlio Vagas, São Paulo, 2014. Disponível em: <Disponível em: http://www.agroanalysis.com.br $>$. Acesso em: maio de 2018 .

ALBUQUERQUE, C. L. F. et al. Knowledge, attitudes and practices regarding the Pap test among women in northeastern Brazil. São Paulo Med. J., São Paulo, v. 132, n. 1, 2014.

ALEXANDRE, N. M. C; GUIRARDELLO, E. B. Adaptación cultural de instrumentos utilizados em salud ocupacional. Rev Panamerde Salud Public, s.1., v. 11, n. 2, p. 109-111, 2002.

ALEXANDRE, N.M.C.; COLUCI, M.Z.O. Validade de conteúdo nos processos de construção e adaptação de instrumentos de medidas. Cienc Saude Coletiva., v. 16, n.7, p. 3061-68, 2011.

ALTAFIN. I. G. Audiência pública aponta avanço do contrabando e falsificação de agrotóxicos. 2016. Disponível em:

https://www12.senado.leg.br/noticias/materias/2016/11/24/audiencia-publica-aponta-avancodo-contrabando-e-falsificacao-de-agrotoxicos. Acesso em: maio de 2018.

ALTIERI, M.A. The ecological impacts of transgenic crops on agroecosystem health. Ecosystem Health, v.6, p. 13-23. 2000.

ALTMAN, D. Practical statistics for medical research. Boca Raton, FL: CRC, 1991.

AMADEI, J. R. P.; FERRAZ, V. C. T. Guia para elaboração de referências: ABNT NBR 6023:2018. Bauru, 2019. 54 p.

ANVERSA, E.T.R.; BASTOS, G.A.N.; NUNES, L.N.; DAL PIZZOL, T.S. Qualidade do processo da assistência pré-natal: unidades básicas de saúde e unidades de Estratégia Saúde da Família em município no Sul do Brasil. Cad Saúde Pública, v. 28, p. 789-800, 2012.

ANVISA. Agência Nacional de Vigilância Sanitária. "Anvisa finaliza readequação toxicológica do Paraquate". Março, 2018. Disponível em: $<\underline{\text { http://portal.anvisa.gov.br/rss/- }}$ /asset_publisher/Zk4q6UQCj9Pn/content/anvisa-finaliza-reavaliacao-toxicologica-doparaquate/219201? inheritRedirect $=$ false $>$. Acesso em: maio de 2018. 
ANVISA. Agência Nacional de Vigilância Sanitária. Programa de análise de resíduos de agrotóxicos em alimentos - PARA. Relatório das análises de amostras monitoradas no período de 2013 a 2015. ANVISA, 2016. Disponível

em: $<$ http://portal.anvisa.gov.br/documents/219201/2782895/Relat $\%$ C3\%B3rio+PARA+Vers \%C3\%A3o+Final/1230de7d-306d-4249-a62c-a68708fab153>. Acesso em: maio de 2018.

ASHDOWN-LAMBERT J.R. A review of low birth weight: predictors, precursors and morbidity outcomes. Royal Society of Health Journal., v. 125, p. 76-83, 2005.

ASSOCIAÇÃO NACIONAL DE DEFESA VEGETAL. Manual de armazenamento de produtos fitossanitários. São Paulo: ANDEF, 1997.

ATAY, S., et al. Validity and reliability of the Clinical Learning Environment, Supervision and Nurse Teacher (CLES+T), Turkish version. Rev Lat Am Enfermagem., v. 26, n. 0, 2018.

AUGUSTO, L. G. S. et al. Dossiê ABRASCO - Um alerta sobre os impactos dos agrotóxicos na saúde. Parte 2 - Agrotóxicos, Saúde, Ambiente e Sustentabilidade. Rio de Janeiro: ABRASCO, 2012.

BADIA, X.; ALONSO, J. Re-scaling the Spanish version of the Sickness Impact Profi le: an opportunity for the assessment of cross-cultural equivalence. J Clin Epidemiol., v.48, n.7, p. 949-57, 1995.

BAIARDI, A.; ALENCAR, C. M. M. Agricultura familiar, seu interesse acadêmico, sua lógica constitutiva e sua resiliência no Brasil. Rev de Econom e Sociologia Rural, v.52, p.45-62, 2014.

BARBOSA, L.C.A. Os pesticidas, o homem e o meio ambiente. Minas Gerais: Ed. UFV, 2004.

BATISTA FILHO, M.; MELO, M. N. T. Alimentação, agrotóxicos e saúde. Rev. Bras. Saude Mater. Infant., Recife, v. 12, n. 2, 2012.

BEATON, D. E.; BOMBARDIER, C.; GUILLEMIN, F.; FERRAZ, M. B. Guidelines for the process of cross-cultural adaptation of self-report measures. Spine, v.25, n. 24, p. 3186-3191, 2000.

BEATON, D; BOMBARDIER, C; GUILLEMIN, F; FERRAZ, M.B. Recommendations for the cross-cultural adaptation of the DASH \& QuickDASH outcome measures. Institute for Work \& Health; 2007 . Disponível

em: <http://www.dash.iwh.on.ca/sites/dash/files/downloads/cross_cultural_adaptation_2007. pdf. >. Acesso em: maio de 2018.

BECK, A. T.; STEER, R. A. Manual for the Beck Depression inventory-II. San Antonio: Psychological Corporation., 1996.

BELCHIOR, D.C.V.; et al. Impactos de agrotóxicos sobre o meio ambiente e a saúde humana. Cadernos de Ciência \& Tecnologia, Brasília, v. 34, n. 1, p. 135-151, jan./abr. 2014 
BERTANI, A. L.; GARCIA, T.; TANNI, S. E. GODOY, I. Prevenção do tabagismo durante a gravidez: a importância do conhecimento materno dos riscos à saúde e das opções de tratamento disponíveis. J. bras. pneumol. [conectados]., v. 41, n. 2, p. 175-181, 2015.

BOCHNER, R. Sistema Nacional de Informações Tóxico-Farmacológicas SINITOX e as intoxicações humanas por agrotóxicos no Brasil. Ciênc. saúde coletiva, Rio de Janeiro, v. 12, n. 1, Mar. 2007.

BOHNER, T. O. L.; ARAÚJO, L. E. B.; NISHIJIMA, T. O impacto ambiental do uso de agrotóxicos no meio ambiente e na saúde dos trabalhadores rurais. Revista Eletrônica do Curso de Direito, Santa Maria, v. 8, n. especial, p. 329-341, 2013.

BOMBARDI, L. M. Geografia do Uso de Agrotóxicos no Brasil e Conexões com a União Europeia. São Paulo: FFLCH - USP 2017

BORGES, A. M. et al. Agricultura familiar e a conservação da saúde humana e ambiental. Rev. Bras. Enferm., Brasília, v. 69, n. 2, p. 326-334, Apr. 2016.

BRACHER, E.S.B. Adaptação e validação da versão em português da escala graduada de dor crônica para o contexto cultural brasileiro [tese]. São Paulo: Faculdade de Medicina, Universidade de São Paulo; 2008.

BRAGON, R. Marco que libera agrotóxicos avança na Câmara. Abril de 2018. Disponível $\mathrm{em}:<$ https://www1.folha.uol.com.br/mercado/2018/04/marco-que-libera-agrotoxicos-avancana-camara.shtml $>$. Acesso em: maio de 2018.

BRAMATTI, L.; MORATA, T. C.; MARQUES, J. M.; MARTINI, U.G. Tradução e adaptação do questionário "crenças e atitudes sobre prevenção de perda auditiva" para o português do Brasil. Rev CEFAC., v.14, p. 65-78, 2012.

BRASIL. Constituição (1988). Constituição da República Federativa do Brasil: promulgada em 5 de outubro de 1988.

BRASIL. ANVISA. Agência Nacional de Vigilância Sanitária. Resolução - Lei No 9.782. Promulgada em 26 de Janeiro de 1999. Define o Sistema Nacional de Vigilância Sanitária, cria a Agência Nacional de Vigilância Sanitária, e dá outras providências. Disponível em:

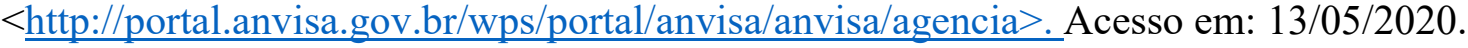

BRASIL. Comissão Intergestores Tripartite. Resolução no 3, de 6 de dezembro de 2011. Estabelece estratégias e ações que orientam o Plano Operativo da Política Nacional de Saúde Integral das Populações do Campo e da Floresta, no âmbito do Sistema Único de Saúde (SUS). Brasília, 2011. Disponível em:

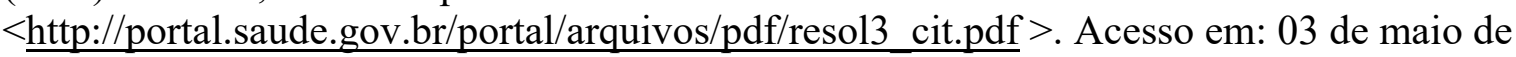
2020 .

BRASIL. Decreto n ${ }^{\circ}$ 7.508, de 28 de junho de 2011. Regulamenta a Lei no 8.080, de 19 de setembro de 1990, para dispor sobre a organização do Sistema Único de Saúde - SUS, o planejamento da saúde, a assistência à saúde e a articulação interfederativa, e dá outras providências. Diário Oficial da União 2011; 29 jun. 
BRASIL. Decreto-Lei $\mathbf{n}^{0} 6299$ de 2002. Dispõe que o registro prévio do agrotóxico será o do princípio ativo; dá competência à União para legislar sobre destruição de embalagem do defensivo agrícola. Diário Oficial da República Federativa do Brasil, Poder Executivo, Brasília, DF. Maio de 2018. Disponível em $<$ http://www.camara.gov.br/proposicoesWeb/fichadetramitacao?idProposicao=46249>. Acesso em: maio de 2018.

BRASIL. Decreto-Lei n ${ }^{0} 6299$ de 2002. Dispõe que o registro prévio do agrotóxico será o do princípio ativo; dá competência à União para legislar sobre destruição de embalagem do defensivo agrícola. Diário Oficial da República Federativa do Brasil, Poder Executivo, Brasília, DF. Maio de 2018. Disponível em $<$ http://www.camara.gov.br/proposicoesWeb/fichadetramitacao?idProposicao=46249>. Acesso em: maio de 2018.

BRASIL. Diário Oficial da União. Valores referentes a média do salário Mínimo Brasileiro vigente entre 2018 e 2019. Disponível em: $<$ http://www.in.gov.br/materia//asset_publisher/Kujrw0TZC2Mb/content/id/57510734/do1esp-2019-01-01-decreto-n-9-661de-1-de-janeiro-de-2019-57510684>. Acesso em março de 2020.

BRASIL. Lei no 11.265, de 03 de janeiro de 2006. Regulamenta a comercialização de alimentos para lactentes e crianças de primeira infância e também a de produtos de puericultura correlatos. Diário Oficial da União, Brasília, DF, 04 jan. 2006. Seção 1, p. 5.

BRASIL. Lei no 11.770, de 9 de setembro de 2008. Cria o Programa Empresa Cidadã, destinado à prorrogação da licença-maternidade mediante concessão de incentivo fiscal, e altera a Lei no 8.212, de 24 de julho de 1991. Diário Oficial da União, Brasília, DF, 10 set.2008. Seção 1, p. 71.

BRASIL. Lei $\mathbf{n}^{\mathbf{0}}$ 13.257, de 08 de março de 2016. Dispõe sobre as políticas públicas para a primeira infância e altera a Lei $\mathrm{n}^{\circ} 8.069$, de 13 de julho de 1990 (Estatuto da Criança e do Adolescente), o Decreto-Lei no 3.689 , de 3 de outubro de 1941 (Código de Processo Penal), a Consolidação das Leis do Trabalho (CLT), aprovada pelo Decreto-Lei $\mathrm{n}^{\circ} 5.452$, de $1^{\circ}$ de maio de 1943, a Lei n ${ }^{\text {o }} 11.770$, de 9 de setembro de 2008, e a Lei no 12.662, de 5 de junho de 2012. Diário Oficial da União, Brasília, DF, 09 març.2016. Seção 1, p. 1.

BRASIL. Ministério da Agricultura e do Abastecimento. Lei $\mathrm{n}^{\circ}$ 7.802. Promulgada em 11 de julho de 1989. In: Legislação federal de agrotóxicos e afins. Brasília (DF):1998.

BRASIL. Ministério da Agricultura, Pecuária e Abastecimento. 2017. Disponível em: $<$ http://www.agricultura.gov.br/noticias/valor-da-producao-agropecuaria-de-2017-e-de-r-5504-bilhoes>. Acesso em abril de 2018.

BRASIL. Ministério da Agricultura. Portal Brasil: Agropecuária Brasileira é uma das que mais cresce no mundo. Set. 2017. Disponível em:

$<$ http://www.brasil.gov.br/editoria/infraestrutura/2017/05/agropecuaria-brasileira-e-uma-dasque-mais-cresce-no-mundo $>$. Acesso em 21 de maio de 2018.

BRASIL. Ministério da Educação; Instituto Nacional do Desenvolvimento da Educação. Manual do aplicador do estudo CAP. Brasília: MEC; 2002. 
BRASIL. Ministério da Saúde (MS). Manual de planejamento no SUS Brasília: MS; 2016. (Série Articulação Interfederativa; v. 4).

BRASIL. Ministério da Saúde. Agência Nacional de Vigilância Sanitária. Resolução RDC n ${ }^{\circ}$ 19. Promulgada em de 03 de fevereiro de 2005. Cria a Rede Nacional de Centros de Informação e Assistência Toxicológica - RENACIAT. Diário Oficial da União 2005; 04 fev.

BRASIL. Ministério da Saúde. Atenção ao pré-natal de baixo risco [Internet]. Brasília: Ministério da Saúde; 2012. 318 p. (Série A. Normas e Manuais Técnicos) (Cadernos de Atenção Básica, n. 32). Disponível em: Disponível em:

$<$ http://bvsms.saude.gov.br/bvs/publicacoes/cadernos_atencao_basica_32_prenatal.pdf $>$

BRASIL. Ministério da Saúde. Contaminantes Ambientais e Substâncias Químicas (VIGIQUIM). Portal da Saúde, SUS. 2009b. Disponível em:

http://portal.saude.gov.br/portal/saude/visualizar_texto.cfm?idtxt=21587.

BRASIL. Ministério da Saúde. Departamento de Ações Programáticas Estratégicas. Diretrizes para atenção integral à saúde do trabalhador de complexidade diferenciada: protocolo de atenção à saúde dos trabalhadores expostos a agrotóxicos [Internet]. Brasília; 2006. Disponível

em: $<\underline{\text { http://bvsms.saude.gov.br/bvs/publicacoes/protocolo atencao saude trab exp agrotoxi }}$ cos.pdf >. Acesso em: Maio de 2018.

BRASIL. Ministério da Saúde. Fundação Nacional de Saúde. Portaria n. ${ }^{0}$ 73, de 9 de março de 1998. Constitui comissão para desenvolver os instrumentos, definir fluxos e no novo soft ware do Sinan. Boletim de Serviço da Funasa, Brasília, 20 mar. 1998.

BRASIL. Ministério da Saúde. Gabinete do Ministro. Portaria $\mathrm{n}^{\circ} 569$, de $1^{\circ}$ de junho de 2000. Instituir o Programa de Humanização no Pré-natal e Nascimento, no âmbito do Sistema Único de Saúde. Diário Oficial da União, Brasília, DF, de 8 de junho de 2000, Seção 1, Páginas 4, 5 e 6 .

BRASIL. Ministério da Saúde. Manual de procedimentos de vigilância em saúde ambiental relacionada à qualidade da água para consumo humano. Brasília, DF, 2006.

BRASIL. Ministério da Saúde. Manual prático para implementação da Rede Cegonha. Brasília: Ministério da Saúde; 2011.

BRASIL. Ministério da Saúde. Plano Integrado de Ações de Vigilância em Saúde de Populações Expostas a Agrotóxicos. Brasília: Ministério da Saúde; 2009a.

BRASIL. Ministério da Saúde. Política Nacional de Atenção Integral à Saúde da Mulher: Princípios e Diretrizes. Brasília, 2011.

BRASIL. Ministério da Saúde. Política Nacional de Saúde Integral das Populações do Campo e da Floresta Brasília - DF 2013. Disponível em:

$<\underline{\text { https://bvsms.saude.gov.br/bvs/publicacoes/politica_nacional_saude_populacoes_campo.pdf }}$ $\geq$. Acesso em abril de 2020. 
BRASIL. Ministério da Saúde. Portaria MS n 518, de 25 de março de 2004. Estabelece os procedimentos e responsabilidades relativos ao controle e vigilância da qualidade da água para consumo humano e seu padrão de potabilidade, e dá outras providências. Brasília, DF: Ministério da Saúde, 2005. (Série E, Legislação em Saúde).

BRASIL. Ministério da Saúde. Portaria no 1.130, de 5 de agosto de 2015. Institui a Política Nacional de Atenção Integral à Saúde da Criança (PNAISC) no âmbito do Sistema Único de Saúde (SUS). Diário Oficial da União 2015; 6 ago.

BRASIL. Ministério da Saúde. Programa de Humanização no Pré-natal e Nascimento. Rev. Bras. Saude Mater. Infant., Recife, v. 2, n. 1, p. 69-71, Apr. 2002.

BRASIL. Ministério da Saúde. Secretaria de Atenção à Saúde. Atenção ao pré-natal de baixo risco. Brasília, DF: Ministério da Saúde, 2012.

BRASIL. Ministério da Saúde. Secretaria de Gestão Estratégica e Participativa. Departamento de Apoio à Gestão Participativa. Política Nacional de Saúde Integral das Populações do

Campo e da Floresta / Ministério da Saúde, Secretaria de Gestão Estratégica e Participativa, Departamento de Apoio à Gestão Participativa. 1. ed.; 1. reimp. Brasília: Editora do Ministério da Saúde, 2013. 48 p.

BRASIL. Ministério da Saúde. Secretaria de Gestão Estratégica e Participativa. Departamento de Apoio à Gestão Participativa. Política Nacional de Saúde Integral das Populações do Campo e da Floresta / Ministério da Saúde, Secretaria de Gestão Estratégica e Participativa, Departamento de Apoio à Gestão Participativa. 1. ed.; 1. reimp. Brasília: Editora do Ministério da Saúde, 2013. 48 p.: il.

BRASIL. Ministério da Saúde. Secretaria de Gestão Estratégica e Participativa. Política Nacional de Saúde Integral das Populações do Campo, da Floresta e das Águas. Brasília, DF: Ministério da Saúde; 2014.

BRASIL. Ministério da Saúde. Secretaria de Vigilância em Saúde. Departamento de Análise em Saúde e Vigilância de Doenças não Transmissíveis. Saúde Brasil 2019 uma análise da situação de saúde com enfoque nas doenças imunopreveníveis e na imunização / Ministério da Saúde, Secretaria de Vigilância em Saúde, Departamento de Análise em Saúde e Vigilância de Doenças não Transmissíveis - Brasília: Ministério da Saúde, 2019. 520 p. : il.

BRASIL. Ministério da Saúde. Secretaria de Vigilância em Saúde. Departamento de Vigilância em Saúde Ambiental e Saúde do Trabalhador. Agrotóxicos na ótica do Sistema Único de Saúde / Ministério da Saúde, Secretaria de Vigilância em Saúde, Departamento de Vigilância em Saúde Ambiental e Saúde do Trabalhador. - Brasília: Ministério da Saúde, 2016. V.2.

BRASIL. Ministério do Trabalho e Emprego. Portaria n $^{\circ}$ 3214, de 08 de junho de 1978. Norma Regulamentadora ${ }^{\circ} 6$ (NR-6). Equipamento de proteção individual. Disponível em: http://www.mte.gov.br/legislacao/normas_regulamentadoras/default.asp. 
BRASIL. Portaria 4.279, de 30 de dezembro de 2010. Estabelece diretrizes para a organização da Rede de Atenção à Saúde no âmbito do Sistema Único de Saúde (SUS). Diário Oficial da União 2011; 31 dez.

BRASIL. Portaria GM 1459, de 24 de junho de 2011. Institui, no âmbito do Sistema Único de Saúde - SUS - a Rede Cegonha. Diário Oficial da União 2011; 25 jun.

BRASIL. Portaria GM 1600, de 7 de julho de 2011. Reformula a Política Nacional de Atenção às Urgências e institui a Rede de Atenção às Urgências no Sistema Único de Saúde (SUS). Diário Oficial da União 2011; 8 jul.

BRASIL. Portaria GM 252, de 19 de fevereiro de 2013. Institui a Rede de Atenção à Saúde das Pessoas com Doenças Crônicas no âmbito do Sistema Único de Saúde (SUS). Diário Oficial da União 2013; 20 fev.

BRASIL. Portaria GM 3088, de 23 de dezembro de 2011. Institui a Rede de Atenção Psicossocial para pessoas com sofrimento ou transtorno mental e com necessidades decorrentes do uso de crack, álcool e outras drogas, no âmbito do Sistema Único de Saúde (SUS). Diário Oficial da União 2011; 24 dez.

BRASIL. Portaria GM 793, de 24 de abril de 2012. Institui a Rede de Cuidados à Pessoa com Deficiência no âmbito do Sistema Único de Saúde. Diário Oficial da União 2013; 25 abr.

BRASIL. Portaria no 11.357 de 06 de maio de 2020. Estabelece os procedimentos e os requisitos técnicos para avaliação de Equipamentos de Proteção Individual - EPI e emissão, renovação ou alteração de Certificado de Aprovação - CA e dá outras providências. Diário Oficial da União, Brasília, DF, 08 mai. 2020. Seção 1, p. 125.

BRASIL. Portaria no 399/GM, de 22 de fevereiro de 2006. Divulga o Pacto pela Saúde 2006 - Consolidação do SUS e aprova as Diretrizes Operacionais do Referido Pacto. Diário Oficial da União 2006; 23 fev.

BRASIL. Produção agrícola por regiões. Disponível em: $<\underline{\mathrm{http}}$ ://www.brasil.gov.br/economia-eemprego/2014/08/ibge.png/view?TSPD $101 \mathrm{R} 0=\mathrm{aa} 8 \mathrm{~d} 54 \mathrm{e} 5701751 \mathrm{ba} 9 \mathrm{~b} 740 \mathrm{bae} 4 \mathrm{~b} 5 \mathrm{~d} 0 \mathrm{e} 41 \mathrm{xS}$ o $000000000000000008 \mathrm{c} 935 \mathrm{~b} 1 \mathrm{ffff} 00000000000000000000000000005 \mathrm{aa} 9382 \mathrm{e} 00408 \mathrm{f} 267 \mathrm{~d}$. $>\mathrm{A}$ cesso em: maio de 2018.

BRASIL. Programa Nacional de Vigilância da qualidade da agua para consumo humano. 2016.

BRASIL. Projeto-Lei $\mathbf{n}^{0}$ 6670/2016. Institui a Política Nacional de Redução de Agrotóxicos PNARA, e dá outras providencias. Diário Oficial da República Federativa do Brasil, Poder Executivo, Brasília, DF. Maio de 2018. Disponível em $<$ http://www.camara.gov.br/proposicoesWeb/fichadetramitacao?idProposicao=46249>. Acesso em: maio de 2018.

BRASIL. Projeto-lei no 2295 de 15 de abril de 2019. Altera a Lei $n^{\circ} 10.048$, de 8 de novembro de 2000, para estabelecer a prioridade no Sistema Único de Saúde para agricultor familiar que more distante do local de atendimento. Câmara dos Deputados: projeto de Lei, Brasília, 15 abr 2019. Disponível em: 
$<$ https://www.lexml.gov.br/urn/urn:lex:br:camara.deputados:projeto.lei;pl:2019-04-

15;2295.>Acesso em: 22 de maio de 2020.

BRENT, R. L.; BACKMAN D. A. Environmental teratogens. Bulletin of the New York Academy of Medicine, v. 66, n. 2, 1990.

BRITO, F. O deslocamento da população brasileira para as metrópoles. Estud. av. São Paulo, v. 20, n. 57, p. 221-236, agosto de 2006. Disponível em

$<$ http://www.scielo.br/scielo.php?script=sci_arttext\&pid=S0103-

$40142006000200017 \& \operatorname{lng}=\mathrm{en} \& n r m=\mathrm{iso}>$. Acesso em: maio de 2018.

BRUMER, A. A problemática dos jovens rurais na pós-modernidade. VII Congresso Latino-Americano de Sociologia Rural. Quito, Equador: Alasru. 2006.

BUENO, M. R. S.; et al. Validação do protocolo de avaliação miofuncional orofacial MBGR para adultos com disfunção temporomandibular com deslocamento de disco com redução.

CoDAS, São Paulo, v. 32, n. 4, 2020.

BULOW A. E.; FOLETO E. M. O homem do campo e os agrotóxicos: Práticas e discursos no município de Novo Cabrais/RS. Dissertação de Mestrado. Universidade Federal de Santa Maria. Santa Maria, 2008.

BURNS C.J.; et al. Pesticide exposure and neurodevelopmental outcomes: review of the epidemiologic and animal studies. J Toxicol Environ Health B Crit Rev; vol. 16, n. 3-4, p.127-283, 2013.

CABANA, M.D; et al. Why don't physicians follow clinical practice guidelines? A framework for improvement. JAMA, v. 282, n. 15, p. 1458-1465, 1999.

CALVERT G.M., HIGGINS S.A. Using surveillance data to promote occupational health and safety policies and practice at the state level: a case study. Am J Ind Med. EUA v. 53, n. 2, p.188-193. 2010

CALVERT-G.M.; et al. Acute occupational pesticide-related illness in the US, 1998-1999: Surveillance findings from the SENSOR-pesticides program. Am J Ind Med. EUA, v. 45, n. 1, p. 14-23, 2004.

CAMARANO, A.A.; ABRAMOVAY, R. Êxodo rural,envelhecimento e masculinização no Brasil: panorama dos últimos 50 anos. Rio de Janeiro: IPEA, 1999. 28p. Disponível em: $<$ http://www.dominiopublico.gov.br/download/ texto/td_0621.pdf $>$. Acesso em: 22 de junho de 2020.

CANDEIAS, N. M. F. Assistência pré-natal: conhecimentos, atitudes e práticas de mulheres internadas no Serviço de Obstetrícia de um hospital do município de São Paulo, Brasil. Rev. Saúde Pública, São Paulo, v. 14, n. 4, Dez. 1980.

CANO, S.J.; HOBART, J.C.; The problem with health measurement. Patient Prefer Adherence., v.5, p. 279-90, 2011.

CARDOSO, D. F. B, et al. Tradução, adaptação cultural e validação preliminar de 
instrumentos para educadores de enfermagem portugueses em relação à prática baseada em evidências. Enfermeira Atual da Costa Rica, San José, n. 38, p. 1-17, junho de 2020. Disponível em $<$ http://www.scielo.sa.cr/scielo.php?script=sci_arttext\&pid=S1409$45682020000100001 \& \operatorname{lng}=\mathrm{en} \& \mathrm{nrm}=\mathrm{iso}>$. Acesso em 15 de maio de 2020.

CARDOSO, L. A. A categoria trabalho no capitalismo contemporâneo. Tempo soc. São Paulo, v. 23, n. 2, p. 265-295, novembro de 2011. Disponível em $<$ http://www.scielo.br/scielo.php?script=sci_arttext\&pid=S010320702011000200011\&lng=en\&nrm=iso>. Acesso em 23 de junho de 2020.

CARLSON, B. M. Distúrbios do desenvolvimento: causas, mecanismos e padrões In: Embriologia humana e biologia do desenvolvimento. Rio de Janeiro: Guanabara Koogan, p. 109-124, 1996.

CARNEIRO, F. F. (Org.) Dossiê ABRASCO: um alerta sobre os impactos dos agrotóxicos na saúde / Organização de Fernando Ferreira Carneiro, Lia Giraldo da Silva Augusto, Raquel Maria Rigotto, Karen Friedrich e André Campos Búrigo. - Rio de Janeiro: ABRASCO; 2012. $1^{\text {a }}$ Parte. 98 p.

CARNEIRO, F. F. (Org.) Dossiê ABRASCO: um alerta sobre os impactos dos agrotóxicos na saúde. Rio de Janeiro: EPSJV; São Paulo: Expressão Popular, 2015.

CARVALHO, A. L. B.; JESUS, W. L. A.; SENRA, I. M. V. Regionalização no SUS: processo de implementação, desafios e perspectivas na visão crítica de gestores do sistema. Cien Saude Colet [online]. 2017, v. 22, n. 4 [Acessado 26 Junho 2020],pp. 1155-

1164. Disponível em: <https://doi.org/10.1590/1413-81232017224.30252016>. ISSN 16784561 .

CASSOL, K.; MAGNI, C. Tradução e adaptação transcultural para a língua portuguesa do protocolo KAP - "Knowledges, Attitudes and Practices". Convibra Online Conference - Gestão, Educação e Promoção da Saúde. Instituto Pantex de Pesquisa, São Paulo. 2017.

CASSOL, K.; MAGNI, C. Tradução e adaptação transcultural para a língua portuguesa do protocolo KAP - "Knowledges, Attitudes and Practices". 2015. Dissertação (Mestrado em Desenvolvimento Comunitário) - UNICENTRO - Universidade Estadual do Centro Oeste, Irati, 2015.

CASSOL, K, et al. Efeitos dos agrotóxicos na saúde auditiva de trabalhadores

rurais. Distúrbios da Comunicação, [S.1.], v. 32, n. 1, p. 152-164, abr. 2020. Disponível em: $<$ https://revistas.pucsp.br/dic/article/view/43506>. Acesso em: 02 jul. 2020.

CASTRO J.S.M.; CONFALONIERI U. Uso de agrotóxicos no Município de Cachoeiras de Macacu (RJ). Cien Saude Colet, v. 10, n.2, p. 473- 82, 2005.

CAVIERES, M. F. F. Exposición a pesticidas y toxicidad reproductiva y del desarrollo en humanos: análisis da la evidencia epidemilógica y experimental. Rev. Med. Chile, v. 132, n. 7, p. 873-879. 2004.

CESAR, J. A., et al. The use of maternal and child health services in three population-based cohorts in Southern Brazil, 1982-2004. Cad Saúde Pública, v. 24, n. 3, p. 427-36, 2008. 
CHIN, W.W.; NEWSTED, P.R. Structural equation modelling analysis with small samples using partial least squares. In.: Hoyle RH. Statistical strategies for small sample research. Thousand Oaks, CA: Sage; p. 307-41, 1999.

CHRISMAN, J. R. Avaliação da contaminação por agrotóxicos em mulheres grávidas residentes no município de Nova Friburgo, Rio de Janeiro. Rio de Janeiro: s.n., 2008. [dissertação - Mestrado] - Escola Nacional de Saúde Pública Sergio Arouca, Rio de Janeiro, 2008.

CLEMENTI M., et al. A study of the impact of agricultural pesticide use on the prevalence of birth defects in Northeast Italy. Reproductive Toxicology, v. 24, p.1- 8, 2007.

COCKEY C.D. More babies born at very low birth weight linked to rise in infant biomonitoring in epidemiologic studies of birth outcomes. Environ. Health Perspect, v. 113, n. 4, p.494-498, 2005.

COIMBRA, L.C. et al. Factors associated with inadequacy of prenatal care utilization. Rev Saúde Pública, v. 37, n. 4, p. 456-62, 2003.

COLUCI, M.Z.O.; ALEXANDRE, N.M.C., MILANI, D. Construction of measurement instruments in the area of health. Cienc Saúde Coletiva., v. 20, n. 3, p. 925-36, 2015.

CONAB - Companhia Nacional de Abastecimento. Acomp. safra bras. grãos, v. 7 - Safra 2019/20 - Nono levantamento, Brasília, p. 1-31 junho 2020.

CONAB - Companhia Nacional de Abastecimento. Receita bruta dos produtores rurais brasileiros / responsável técnico Ângelo Bressan Filho - v. 1 (2013 -) - Brasília: Conab, 2013- v. Disponível em: <http://www.conab.gov.br $>$. Acesso em: junho de 2018.

CORDEIRO, Z. J. M. Sistema de Produção de Banana para o Estado do Pará. Sistema de Produção, 9 - versão eletrônica. Embrapa Mandioca e Fruticultura, Jan. 2003. Disponível em: http://sistemasdeproducao.cnptia.embrapa.br/FontesHTML/Banana/BananaPara/agr otoxicos. htm. Acesso em: 23 de junho de 2020.

CORTINA, J.M. What is coefficient alpha? An examination of theory and applications. $\mathbf{J}$ Appl Psychol. 1993;78(1):98-104.

COSTA, C.C. Conhecimento, atitude e prática dos enfermeiros acerca do controle da sífilis na gestação. (Dissertação de Mestrado). Fortaleza (CE): Universidade Federal do Ceará, 2012.

COSTA, I.K.F. et al. Construction and validation of a distance Basic Life Support Course. Rev Bras Enferm., v. 71, n. 6, p. 2698-66, 2018.

COSTA, R.R.; TAKESSHITA, W.M.; JACOBUCCI FARAH, G. Levantamento epidemiológico de fissuras labiopalatais no município de Maringá e região. Rev Assoc Paul Cir Dent., v. 67, n. 1, p. 40-4, 2013. 
COSTA, T. F. et al. Validation of Bakas Caregiving Outcome Scale for brazilian portuguese. Rev. Latino-Am. Enfermagem., v. 28, 2020.

COUTINHO, J. A. G. et al. uso de agrotóxicos no município de Pati do Alferes: um estudo de caso. Caderno de Geociências, n.10, p. 23-31, 1994.

CREMONESE, Cleber et al. Exposição a agrotóxicos e eventos adversos na gravidez no Sul do Brasil, 1996-2000. Cad. Saúde Pública, Rio de Janeiro, v. 28, n. 7, p. 1263-1272, July 2012.

CRONBACH, L. J. Coeficiente alfa e estrutura interna dos testes. Psychometrika 16, 297 334 (1951). Disponível em: $<$ https://doi.org/10.1007/BF02310555>. Acesso em 28 de junho de 2020.

CRONBACH, L.J. Coefficient alpha and the internal structure of tests. Psychometrika, v. 16, n. 3, p. 297-334, 1951.

CURADO, M.A.S.; TELES, J.; MARÔCO, J. Analysis of variables that are not directly observable: Influence on decision-making during the research process. Rev Esc Enferm USP., v. 48, n. 1, p. 146-52, 2014.

DEERE, C. Os direitos da mulher à terra e os movimentos sociais rurais na reforma agrária. Revista Estudos Feministas, v.12, n. 1, p.175-204, 2004.

DEERE, C.; LEÓN, M. O empoderamento da mulher: direitos a terra e direitos de propriedade na América Latina. Porto Alegre: Ufrgs. 2002.

DELLAMATRICE, P. M.; MONTEIRO, R. T. R. Principais aspectos da poluição de rios brasileiros por pesticidas. Rev. bras. eng. agríc. ambient., Campina Grande, v. 18, n. 12, p. 1296-1301, Dec. 2014.

DMOCHOWSKA-MROCZEK, H.; LEBENSZTEJN, W.; TOLWIŃSKI, K. Severe intoxication with Dipterex in a pregnant woman. Polski tygodnik lekarski (Warsaw, Poland: 1960), v. 27, n. 36, p. 1406-1407, 1972.

DORFMAN, A.; FRANÇA, A. B.C.; SOARES, G.O. Marcos legais e redes de contrabando de agrotóxicos: análise escalar a partir da fronteira Brasil-Uruguai. TerraPlural, v.8, n.1, p. 37-53, 2014.

DUTRA, L. S.; FERREIRA, A.P. Associação entre malformações congênitas e a utilização de agrotóxicos em monoculturas no Paraná, Brasil. Saúde debate [online]. 2017, vol.41, n.spe2, pp.241-253.

EXAME. Disponível em: $<$ https://exame.abril.com.br/revista-exame/400-maiores-doagronegocio/ $>$. Acesso em 22 de maio de 2018.

FACCINI, L. S., et al. Avaliação de teratógenos na população brasileira. Cien Saude Colet, v. 7, n. 1, p. 65-71. 2002. 
FARIA, N. M. X; FACCHINI, L. A.; FASSA, A.G.; TOMIASI, E. Trabalho rural e intoxicações por agrotóxicos. Cad. Saúde Pública, v. 20, n. 5, p.1298-1308, 2004.

FEIJÓ, M.K., et al. Adaptação transcultural e validação da European Heart Failure Self-care Behavior Scale para o português do Brasil. Rev Latinoam Enferm., v. 20, n. 5, p. 988-996, 2012.

FELDT, L. S.; CHARTER, R. A. Estimating the reliability of a test split into two parts of equal or unequal length. Psychol Methods., v.8,p.102-9, 2003.

FELÍCIO C.M.; FERREIRA, C.L.P. Protocol of orofacial myofunctional evaluation with scores. Int J Pediatr Otorhinolaryngol, v. 72, n. 3, p. 367-75, 2008.

FELÍCIO, C.M.; MEDEIROS, A.P.; DE OLIVEIRAMELCHIOR, M. Validity of the 'protocol of oro-facial myofunctional evaluation with scores' for young and adult subjects. $\mathbf{J}$ Oral Rehabil., v. 39, n. 10, p. 744-53, 2012.

FELICIO, Cláudia Maria de et al. Protocolo de Avaliação Miofuncional Orofacial com Escores Informatizado: usabilidade e validade. CoDAS, São Paulo, v. 26, n. 4, p. 322327, July 2014.

FERREIRA, B.; ALVES, F. Juventude rural: alguns impasses e sua importância para a agricultura familiar. In: CASTRO, J. A.; AQUINO, L. M. C.; ANDRADE, C. C. Juventude e políticas sociais no Brasil. Brasília: IPEA, 2009. p. 243-257.

FERREIRA, C. B. et al . Produtividade Agrícola nos Países da América Latina. Rev. Econ. Sociol. Rural, Brasília, v. 54, n. 3, p. 437-458, Sept. 2016. Disponível em $<$ http://www.scielo.br/scielo.php?script=sci_arttext\&pid=S010320032016000300437\&lng=en\&nrm=iso>. Acesso em: Mai. 2018.

FLECK, M.P.A.; The World Health Organization instrument to evaluate quality of life (WHOQOL-100): characteristics and perspectives. Cienc Saúde Coletiva., v.5, n. 1, p. 33-8, 2000.

FLEISS, J. Statistical methods for rates and proportions. New York: John Wiley \& Sons, 1981.

FREIRE, F.C. Avaliação dos possíveis efeitos sobre o desfecho da gravidez em uma população de mulheres expostas cronicamente a agrotóxicos, na região do vale do São Lourenço, Nova Friburgo, RJ [Dissertação de Mestrado]. Rio de Janeiro: Escola Nacional de Saúde Pública Sergio Arouca, Fundação Oswaldo Cruz; 2005.

FREIRE, M.; ARREGUY-SENA, C.; \& MÜLLER, P. Adaptação transcultural e validação de conteúdo e semântica do Difficult Intravenous Access Score para uso pediátrico no Brasil. Revista Latino-Americana De Enfermagem, v.25, e2920, 2017. Disponível em $<$ https://doi.org/10.1590/1518-8345.1785.2920>. Acesso em 22 de junho de 2020.

FREITAS, R. E. Produtividade Agricola no Brasil: desempenho e determinantes. NEGRI F.; CAVALCANTE, L. R (org). Brasília: ABDI: IPEA, 2014. 445p. Disponível em: 
$<$ http://www.ipea.gov.br/agencia/images/stories/PDFs/livros/livros/produtividade no brasil miolo cap12.pdf $>$. Acesso em: Maio de 2018.

FUNDAÇÃO OSWALDO CRUZ. Centro de Informação Científica e Tecnológica/Sistema Nacional de Informações Tóxico-Farmacológicas. Estatística Anual de Casos de Intoxicação e Envenenamento. Brasil, 2017. Disponível em: http://www.fiocruz.br/sinitox. Acesso em: 22 de jun. 2020.

GALEA, S., TRACY, M. Participation rates in epidemiologic studies. Ann Epidemiol., v. 17, n. 9, p. 643-53, 2007.

GARNE, E. et al. Paper 5: surveillance of multiple congenital anomalies: implementation of a computer algorithm in European registers for classification of cases. Birth Defects Res A Clin Mol Teratol, v. 91, n. 1, p. 44-50, 2011.

GARRO-MONGE, G. Inocuidad de cultivos y alimentos biotecnológicos, "20 años de comercialización”. Tecnología en Marcha, Cartago, v. 30, n. 2, p. 67-74, Jun, 2017.

GARRY, V.F. et al. Reproductive outcomes in the women of the red river valley of the north. I. The spouses of pesticide applicators: pregnancy loss, age at menarche, and exposures to pesticides. Journal of Toxicology and Environmental Health, Part A, v. 65, p. 769-786, 2002.

GBD 2015 Maternal Mortality Collaborators. Global, regional, and national levels of maternal mortality, 1990-2015: a systematic analysis for the Global Burden of Disease Study 2015.

Lancet 2016; 388:1775-812.

GIUSTI, E.; BEFI-LOPES, D.M. Tradução e adaptação transcultural de instrumentos estrangeiros para o Português brasileiro. Pró-Fono: Revista de atualização científica, São Paulo, v. 20, n. 3, p. 207-210, jul./set. 2008. Disponível em:

$<$ http://www.scielo.br/pdf/pfono/v20n3/12.pdf>. Acesso em: 23 de maio de 2018.

GOLDMAN, L., et al. Risk Behaviors for Pesticide Exposure Among Pregnant Women Living in Farmworker Households in Salinas, California. American Journal Of Industrial Medicine., v. 45, p.491-499. 2004.

GOMES, A. L. A., et al. Validation and reliability of the scale Self-efficacy and their child's level of asthma control. Rev. Bras. Enferm., v.71, n.2, p.406-412, 2018.

GÓMEZ GARCÍA, J.; RICO GONZÁLEZ, M. Rural Development, Population Aging and Gender in Spain: the Case of Rural Women in the Autonomous Community of Castilla $y$ León. En European Congress of the European Regional Science Association. Porto: Portugal, 2004.

GONÇALVES, Silvio Romero et al. Defeitos congênitos e exposição a agrotóxicos no Vale do São Francisco Congenital defects and exposure to pesticides in São Francisco Valley. Revista Brasileira de Ginecologia e Obstetrícia, v. 33, n. 1, p. 20-26, 2011.

GUILLEMIN, F. Cross-cultural adaptation and validation of health status measures. Scand J Rheumatol, v. 24, n. 2, p. 61-63, 1995. 
GUILLEMIN, F.; BOMBARDIER, C.; BEATON, D. Cross-cultural adaptation of healthrelated quality of life measures: literature review and proposed guidelines. J Clin Epidemiol., v. 6, n. 12, p. 1417-32, 1993.

GUNTHER, H. Ginástica médica em ginecologia e obstetrícia. São Paulo-SP: Manole, 1980.

GUYTON \& HALL. Tratado de fisiologia médica. Rio de Janeiro-RJ: Editora Guanabara Koogan S.A, 2002.

HAIR, J. F. J., et al. Multivariate data analysis. 6th ed. Upper Saddle River: Pearson Prentice Hall; 2006.

HEALE, R.; TWYCROSS, A. Validity and reliability in quantitative studies. Evid Based Nurs., v. 18, n. 3, p. 66-7, 2015.

HEREDIA, B.M.A.; CINTRÃO, R.P. Gênero e acesso a políticas públicas no meio rural brasileiro. Revista Nera, v.9, n.8, p.1-28, 2006.

HERMIDA, P. M. V.; ARAUJO, I. E. M. Sistematização da assistência de enfermagem: subsísios para implantação. Rev. bras. enferm., Brasília, v. 59, n. 5, p. 675-679, Oct. 2006.

HERNÁNDEZ, C. Política de crédito rural com perspectiva de gênero: um meio de "empoderamento" para as mulheres rurais? (Tese de doutorado). Porto Alegre:

Universidade Federal do Rio Grande do Sul, 2009.

HOKERBERG, Y. H. M., et al. Cross-cultural validity of the demand-control questionnaire: Swedish and Brazilian workers. Rev. Saúde Pública, v.48, n.3, p.486-496, 2014.

HOSHINO, A.C.H, et al. A autopercepção da saúde auditiva e vestibular de trabalhadores expostos a organofosforados. Rev. CEFAC, v. 11, n.4, p. 681-7, 2009.

IADB - Inter-American Development Bank (2014). America Latina frente a la desigualdad . Washington, D. C. Inter-American Development Bank. Disponível em:

$<$ http://www.iadb.org/en/inter-american-development-bank,2837.html $>$. Acesso em: maio de 2018.

IBGE - INSTITUTO BRASILEIRO DE GEOGRAFIA E ESTATÍSTICA, 2019. Tábua completa de mortalidade para o Brasil - 2018. Rio de Janeiro: IBGE. IBGE - Instituto Brasileiro de Geografia e Estatística, 2019.

IBGE - INSTITUTO BRASILEIRO DE GEOGRAFIA E ESTATÍSTICA. Levantamento Sistemático da Produção Agrícola - LSPA. Abril, 2020.Brasil, 2009. Disponível em: $<$ https://www.ibge.gov.br/estatisticas/economicas/agricultura-e-pecuaria/9201-levantamentosistematico-da-producao-agricola.html $?=\& \mathrm{t}=$ destaques $>$. Acesso em maio de 2020.

IBGE. Indice Brasileiro de Geografia e Estatística. Levantamento Sistemático da Produção Agrícola. 2019. Disponivel em: 
$<$ https://www.ibge.gov.br/estatisticas/economicas/agricultura-e-pecuaria/21814-2017-censoagropecuario.html $?=\& \mathrm{t}=0$-que-e $>$. Acesso em junho de 2019.

IBGE. Indice Brasileiro de Geografia e Estatística. Levantamento Sistemático da Produção Agrícola. 2019. Disponivel em:

$<$ https://www.ibge.gov.br/estatisticas/economicas/agricultura-e-pecuaria/21814-2017-censoagropecuario.html?=\&t=0-que-e $>$. Acesso em junho de 2019.

INSTITUTO BRASILEIRO DO MEIO AMBIENTE E DOS RECURSOS NATURAIS RENOVÁVEIS - IBAMA. Relatório de comercialização de agrotóxicos. Disponível em: $<$ http://www.ibama.gov.br/agrotoxicos/relatorios-de-comercializacao-de-agrotoxicos $>$. Acesso em: maio de 2018.

IPARDES - Instituto Paranaense de Desenvolvimento Econômico e Social. (2016). Paraná em números. Curitiba: Ipardes. Recuperado em 22 dez. 2016, de http://www.ipardes.pr.gov.br.

IPARDES - Instituto Paranaense de Desenvolvimento Econômico e Social. Leituras regionais: mesorregião geográfica Centro-Oriental paranaense. 2020. Disponível em:

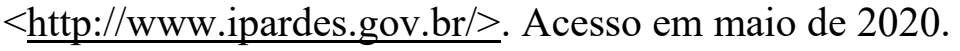

IPARDES. Instituto Paranaense de Desenvolvimento Econômico e Social. Base de Dados do Estado. Disponível em: < $<$ http://www.ipardes.gov.br $>$. Acesso em: 15 jun. 2017.

ISAAA. Área de culturas transgénicas cresce para 185,1 milhões há. CIBPT. 2017. Disponível em: $<$ https://cibpt.wordpress.com/2017/05/05/isaaa-2016-area-de-culturastransgenicas-cresce-para-1851-milhoes-ha/>. Acesso em: maio de 2018.

JACOBSON et al. User's guide on assessing water governance. UNDP, 2013.

MIORIN, J. D., et al. Percepções de agricultores sobre o impacto dos agrotóxicos para a saúde e o meio ambiente. Rev Enferm do Centro Oeste Mineiro. v. 6, n. 3, 2016.

KAJTA, M.; WÓJTOWICZ, A. Neurodevelopmental disorders in response to hormonally active environmental pollutants. Przeglad lekarski, v. 67, n. 11, p. 1194-1199, 2010.

KESZEI, A.P.; NOVAK. M.; STREINER, D.L. Introduction to health measurement scales. J Psychosom Res., v. 68, n. 4, p. 319-23, 2010.

KIMBERLIN, C.L.; WINTERSTEIN, A.G. Validity and reliability of measurement instruments used in research. Am J Health Syst Pharm., v. 65, n. 23, p. 2276-84, 2008.

KLEIN, C. et al. Adaptação transcultural e validação de um questionário de conhecimento sobre insuficiência cardíaca para enfermeiros. Rev Gaúcha Enferm., v.33, n. 1, p. 19$25,2012$.

KORBES, D.; SILVEIRA, A.; HYPPOLITO, M.; MUNARO, G. Alterações no sistema vestibulococlear decorrentes da exposição ao agrotóxico: revisão de literatura. Rev Soc BrasFonoaudiol, v. 15, n. 1, p. 146-52, 2010. 
KORBES, D.; SILVEIRA, A.F.; HYPPOLITO, M.A; MUNARO. Ototoxicidade por organofosforados: descrição dos aspectos ultraestruturais do sistema vestibulococlear de cobaias. Braz J Otorhinolaryngol, v. 76, n. 2, p. 238-44, 2010.

KÓS MI, MIRANDA MF, GUIMARÃES RM, MEYER A. Avaliação do sistema auditivo em agricultores expostos à agrotóxicos. Rev. CEFAC, v. 16, n. 3, p. 941-8, 2014.

KRAMER, S. E.; KAPTEYN, T. S.; FESTEN, J.M.; TOBI, H. Factors in subjective hearing disability. Audiology., v.34, p. 311-20, 1995.

LA TORRE, G.; SESTILI, C.; IAVAZZO, E.; MANNOCCI, A. Fenomeno violenza súbita sul luogo di lavoro nel settore sanitário: validazione della versione italiana del questionario WHO. Clin Ter., v. 168, n. 3, p. 199-202, 2017.

LEITE, A. P. L. L. Sexualidade na adolescência: conhecimentos, atitudes e práticas dos adolescentes estudantes do município de Maceió. Recife, [Tese - Mestrado - Universidade de Pernambuco], 2001.

LIMA, A.C.M.A.C.C. et al. Development and validation of a booklet for prevention of vertical HIV transmission. Acta Paul Enferm., v.30, n. 2, p. 181-9, 2017.

LIMA, M. T.; BUCHER, J. S. N. F.; LIMA, J. W. O. A hipertensão arterial sob o olhar de uma população carente: estudo exploratório a partir dos conhecimentos, atitudes e práticas. Cad. Saúde Pública, Rio de Janeiro, v. 20, n. 4, p. 1079-1087, Aug. 2004.

LISBOA, T.K.; LUSA, M. G. Desenvolvimento sustentável com perspectiva de gênero Brasil, México e Cuba: mulheres protagonistas no meio rural. Rev. Estud. Fem., Florianópolis, v. 18, n. 3, p. 871-887, dezembro de 2010.

LIU. L. et al. Global, regional, and national causes of under-5 mortality in 2000-15: an updated systematic analysis with implications for the Sustainable Development Goals. Lancet, v. 388, p.3027-35, 2016.

LOMBARDI, S. Desenvolvimento rural e gênero: a participação das mulheres na organização de um movimento social -o caso da Crabi- Pr. Dissertação de Mestrado. Toledo: Universidade Estadual do Oeste do Paraná, 2006.

LORENZ A. N. et al.Pilot Study of Pesticide Knowledge, Attitudes, and Practices among Pregnant Women in Northern Thailand. International Journal of Environmental Research and Public Health, v. 9, n. 9, p. 3365-83, 2012.

LOURENCO, M. A. E.; TYRRELL, M. A.R. Programas de saúde materno-infantil em Moçambique: marcos evolutivos e a inserção da enfermagem. Esc. Anna Nery, v. 13, n. 3, p. 617-624, 2009.

MACHADO, JMH; PENA PGL (orgs.). Saúde do trabalhador na sociedade brasileira contemporânea. Rio de Janeiro: Editora Fiocruz, 2011.

MAIA, C.; LOPES, M. F. As desigualdades de gênero no contexto do desenvolvimento humano. Unimontes Científica, Montes Claros, v. 1, n. 1, p. 1-15, 2001. 
MARINHO, L.A.B. Conhecimento, Atitude e Prática do Auto-Exame da mama e do Exame de MMG em usuárias dos Centros de Saúde do Município de Campinas. Campinas, 2001.104 p. Tese de Doutorado, UNICAMP.

MARINHO, L.A.B., et al . Conhecimento, atitude e prática do auto-exame das mamas em centros de saúde. Rev. Saúde Pública, São Paulo, v. 37, n. 5, p. 576-582, Oct. 2003

. Disponivel em: $<$ http://www.scielo.br/scielo.php?script=sci_arttext\&pid=S0034$89102003000500005 \& \operatorname{lng}=\mathrm{en} \& n r m=\mathrm{iso}>$. Acesso em 30 May 2018.

MARIO, D.N. et al. Qualidade do Pré-Natal no Brasil: Pesquisa Nacional de Saúde 2013. Cien Saude Colet. 2013. Disponivel em: $<$ http://www.cienciaesaudecoletiva.com.br/artigos/qualidade-do-prenatal-no-brasilpesquisa-nacional-de-saude-2013/16353?id=16353 $>$. Acesso em: maio de 2018.

MARTIN, H. et al. Ultrasonic versus hand filing of dentin: a quantitative study. Oral Surg Oral Med Oral Pathol, Saint Louis, v. 49, n. 1, p. 79-81, Jan. 1980.

MARTINELLI RLC. Validação do protocolo de avaliação do frênulo da língua em bebês [tese]. Bauru: Faculdade de Odontologia de Bauru, Universidade de São Paulo; 2015.

MARTINEZ MONTENEGRO, I.; BAEZA LEIVA, M. . Enfoques de género no papel do mujer rural na agricultura cubana. Prolegómenos [online]., v. 20, n. 39, p. 29-38, 2017.

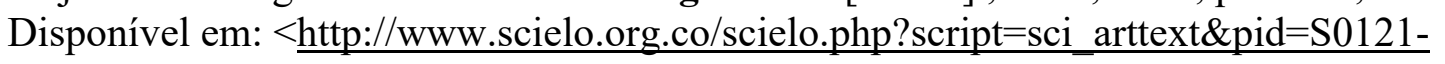

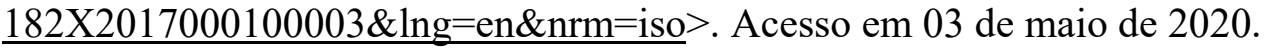

MARTINS, G.A. Sobre confiabilidade e validade. RBGN, v. 8, n.20, p. 1-12, jane-abr, 2006.

MARTINS, L. Audiência pública debate impactos da pulverização aérea de agrotóxicos. Assembleia Legislativa do Estado de São Paulo. Disponível em: $<$ https://www.al.sp.gov.br/noticia/?id=383664>. Acesso em: Maio de 2018.

MAŚLIŃSKA, D.; ZALEWSKA, Z. Effect of dichlorvos, administered to the pregnant rabbits, on the colinesterases activity in the progeny. Folia histochemica et cytochemica, $v$. 16, n. 4, p. 335-341, 1978.

MEIRELLES, L. A.; VEIGA, M. M. DUARTE, F. A contaminação por agrotóxicos e o uso de EPI: análise de aspectos legais e de projeto. Laboreal, v.12, n.2, pp.75-82, 2016.

MELEM, C. Natação para gestantes. São Paulo: ícone, 1997.

MELLO, M., et al. Sucessão hereditária e reprodução social da agricultura familiar. Agricultura em São Paulo, v.50, n. 1, p. 11-24, 2003.

MENEZES FILHO, N.; CAMPOS, G. KOMATSU, B. A Evolução da Produtividade no Brasil. INSPER - Centro de Políticas Públicas. 2014 Ministério da Saúde/Agência Nacional de Vigilância Sanitária. Resolução RDC nº 19, de 03 de fevereiro de 2005. Cria a Rede Nacional de Centros de Informação e Assistência Toxicológica - RENACIAT. Diário Oficial da União 2005; 04 fev. 
MIORIN, J. D; et al. Percepções de agricultores sobre o impacto dos agrotóxicos para a saúde e o meio ambiente. Rev. enferm. Cent.-Oeste Min, v. 6, n. 3, p. 2410-2420, set.-dez. 2016.

MISRA, D.P.; NGUYEN, R.H.N. Environmental tobacco smoke and low birth weight: a hazard in the workplace? Environ. Health Perspect. V. 107n. Suppl 6, p. 897-904, 1999

MOISES, M., et al. Reflexões e contribuições para o Plano Integrado de Ações de Vigilância em Saúde do Ministério da Saúde (MS) de Populações Expostas a Agrotóxicos. Ciênc. saúde coletiva, Rio de Janeiro, v. 16, n. 8, Aug. 2011.

MOKKINK, L.B.; et al. The COSMIN checklist for evaluating the methodological quality of studies on measurement properties: A clarification of its content. BMC Med Res Methodol., v. 18, n. 10, p. $22,2010$.

MONTICIELO, O. A.; et al. Esclerose sistêmica e níveis séricos elevados de organoclorado: uma associação possível? Rev. bras. reumatol; v. 48, n. 1, p. 51-54, jan.-fev. 2008.

MOORE, K. L.; PERSAUD, T. V. N. Malformações congênitas humanas. In: Embriologia clínica. Rio de Janeiro: Guanabara Koogan, p. 136-165, 1994.

MOREIRA, J. C. et al. Avaliação integrada do impacto do uso de agrotóxicos sobre a saúde humana em uma comunidade agrícola de Nova Friburgo, RJ. Cien Saude Colet, v. 7, n.2, p. 299-311, 2002.

MOURA, E. R. F., BEZERRA, C. G., OLIVEIRA, M. S., \& DAMASCENO, M. M. C. Validação de jogo educativo destinado à orientação dietética de portadores de diabetes mellitus. Revista de Atenção Primária à Saúde. v.11, n. 4, p.435-443, 2008.

NEEDHAM L. L., CALAFAT A. M., BARR D. B. Uses and issues of biomonitoring. Int. J. Hyg. Environ.-Health., v. 210, p. 229-238, 2007.

NERO, Luís Augusto et al . Organofosforados e carbamatos no leite produzido em quatro regiões leiteiras no Brasil: ocorrência e ação sobre Listeria monocytogenes e Salmonella spp. Ciênc. Tecnol. Aliment., Campinas, v. 27, n. 1, p. 201-204, Mar. 2007 .

NEVES, H. C. C. et al . Safety of nursing staff and determinants of adherence to personal protective equipment. Rev. Latino-Am. Enfermagem, Ribeirão Preto, v. 19, n. 2, Apr. 2011 .

NEVES, P. D. M.; BELLINI, M. Intoxicações por agrotóxicos na mesorregião norte central paranaense, Brasil - 2002 a 2011. Ciências Saúde coletiva; v.18, n.11, p. 3147-

3156, Nov. 2013.

NICOLAU, A.I.O., et al. Knowledge, attitude and practices regarding condom use among women prisoners: the prevention of STD/HIV in the prison setting. Rev Esc Enferm USP [Internet], v. 46, n.3, p. 711-9, 2012. Disponivel em

$<$ http://www.scielo.br/pdf/reeusp/v46n3/en 25.pdf $>$. Acesso em 29 de maio de 2018.

NINA, N.C.S. 2002. Caracterização sócio-econômica-ambiental do uso de agrotóxicos em uma área de várzea do município de Manacapuru - Am (Amazônia Central). Dissertação 
de Mestrado, Programa de Pós-Graduação em Ciências do Ambiente e Sustentabilidade na Amazônia. Universidade Federal do Amazonas. 123pp

NOBRE, C. D. Modernização agrícola, agrotóxicos e intoxicações: o caso de Santa Cecília do Pavão - PR. 1996. 168f. Dissertação (Mestrado em Geografia) - Universidade de São Paulo, São Paulo, 1996.

NODARI, R.O.; GUERRA, M.P. Avaliação de riscos ambientais de plantas transgênicas. Cadernos de Ciência e Tecnologia, v.18, n.1, p.81-116, 2001.

NUNES, J. T. et al. Qualidade da assistência pré-natal no Brasil: revisão de artigos publicados de 2005 a 2015. Cad. Saúde Colet., Rio de Janeiro, v.24, n. 2, p.252-261, 2016.

NUNNALLY, J.C.; BERNSTEIN, I.H. Psychometric theory. 3rd Ed. New York: McGrawHill; 1994.

OCTAVIANO, C. Muito além da tecnologia: os impactos da Revolução

Verde. ComCiência, Campinas, n. 120, 2010 . Disponível em

$<$ http://comciencia.scielo.br/scielo.php?script=sci_arttext\&pid $=\mathrm{S} 1519$ -

$76542010000600006 \&$ lng=pt\&nrm=iso $>$. Acesso em 23 de junho de 2020.

OLIVEIRA, C.C.C; VARGAS, M.M.; SENA, T.R.R. Saúde auditiva e qualidade de vida em trabalhadores expostos à agrotóxicos. Ciênc Saúde Coletiva, v. 12, n.4, p. 167-9, 2012.

OLIVEIRA, J. A.; NINA, S. F. M. Ambiente e saúde da mulher trabalhadora: transformações numa comunidade da Amazônia brasileira. Saúde soc. [online], v. 23, n. 4, p. 1162-1171, 2014. Disponível em: $<\mathrm{http}: / / \mathrm{www}$. scielo.br/scielo.php?script $=$ sci_arttext\&pid=S0104$12902014000401162 \& \operatorname{lng}=\mathrm{en} \& \mathrm{nrm}=\mathrm{iso}>$. Acesso em 02 de maio de 2020.

OLIVEIRA, J.; Valor da produção agrícola cresceu 20\% em 2016. Governo do Paraná Portal Brasil. 2017. Disponível em: $<$ http://www.brasil.gov.br/economia-eemprego/2017/09/valor-da-producao-agricola-cresceu-20-em2016?TSPD 101 R0=e5b14a9a2f77ef9364edcd1b761f468cc85000000000000000008c935b1 ffff00000000000000000000000000005aa938bd00f247a80c $>$. Acesso em: maio de 2018.

OLIVEIRA, K.; KUZNIER, T.P.; SOUZA, C.C.; CHIANCA, T.C.M. Theoretical and methodological aspects for the cultural adaptation and validation of instruments in nursing. Texto Contexto Enferm., v. 27, n. 2, 2018.

OLIVEIRA, N. P.; MOI, G.P.; ATANAKA-SANTOS, M.; MÁRIO, A.; SILVA, C. Malformações congênitas nos municípios de grande utilização agrícola de Mato Grosso, Brasil. Ciênc. Saúde coletiva [periódico na Internet]., v. 19, n. 10, p. 4123-30, 2014.

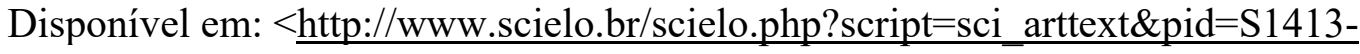
$\underline{81232014001004123 \& \operatorname{lng}=\text { en }>\text {. Acesso em } 20 \text { de maio de } 2020 .}$

OLIVEIRA, S. C., et al . Efeito de uma intervenção educativa na gravidez: ensaio clínico randomizado em cluster. Acta paul. enferm., São Paulo, v. 31, n. 3, p. 291298, June 2018. 
OPAS - Organização Pan-Americana de Saúde. Prevenção e controle de enfermidades genéticas e os defeitos congênitos: relatório de um grupo de consulta. Washington (US): OPAS; 1984.

ORGANIZAÇÃO PAN-AMERICANA DE SAÚDE/ORGANIZAÇÃO MUNDIAL DA SAÚDE (OPAS/OMS). Manual de vigilância da saúde de populações expostas a agrotóxicos. Brasília, DF: Organização Pan-Americana de Saúde/Organização Mundial da Saúde, 1996.

PALMA, DCA. Agrotóxicos em leite humano de mães residentes em Lucas do Rio Verde, MT. Dissertação (Mestrado em Saú- de Coletiva). Universidade Federal de Mato Grosso, Cuiabá, 2011.

PARANÁ. (2016). Valor bruto da produção agropecuária paranaense em 2016. Curitiba: Seab. Recuperado em 04 abr. 2016, de www.pr.gov.br/seab.

PARANA. Intoxicações agudas por agrotóxicos atendimento inicial do paciente intoxicado. Material técnico, 2018.

PARANÁ. Política estadual de saúde do trabalhador, Secretaria do estado do Paraná, Curitiba, agosto de 2011.

PARANÁ. Secretaria de Estado da Saúde (SESA). Linha guia rede mãe paranaense. Paraná, 2012.

PARANÁ. Secretaria de Estado da Saúde do Paraná. Linha Guia da Atenção as populações expostas aos agrotóxicos. Curitiba. 2018

PARANÁ. Secretaria de Estado da Saúde do Paraná. Superintendência de Atenção à Saúde. Linha Guia da Atenção às Populações Expostas aos Agrotóxicos. - 1 ed. - Curitiba: SESA, 2018. $72 \mathrm{p}$.

PASIANE, J. O. Conhecimentos, atitudes e práticas de trabalhadores rurais em relação ao uso de agrotóxicos e biomonitoramento da exposição. 2012. vii, 95 f., il. Dissertação (Mestrado em Ciências da Saúde)—Universidade de Brasília, Brasília, 2012.

PASQUALI, L. Instrumentação psicológica: Fundamentos e práticas. Porto Alegre: Artmed; 2010.

PASQUALI, L. Psicometria: teoria dos testes na psicologia e na educação. Rio de Janeiro: Vozes; 2013.

PASQUALI, L. Psicometria: teoria dos testes na psicologia e na educação. Rio de Janeiro: Vozes; 2011.

PAULILO, M.G.S. Trabalho familiar: uma categoria esquecida de análise. Estudos

Feministas, v.12, n.1. p.229-252, 2004. 
PELAEZ, V., ALBERGONI, L.; GUERRA, M.P. Soja transgênica vs. soja convencional: uma análise comparativa de custos e benefícios. Cadernos de Ciência e Tecnologia, v. 21, n. 2, p. 279-309, 2004.

PELAEZ, V.; ALBERGONI, L. Barreiras técnicas comerciais aos transgênicos no Brasil: a regulação nos estados do sul. Revista Indicadores Econômicos, v.32, n.33, p.201-229, 2004.

PEREIRA, V. V. V. R.; BAZOTTI, A. Ruralidade, agricultura familiar e desenvolvimento. Nota técnica do IPARDES, $\mathrm{n}^{\circ}$ 16. Curitiba, 2010.

PERES, F.; MOREIRA, J.C.; LUZ, Claudio. Os impactos dos agrotóxicos sobre a saúde e o ambiente. Ciênc. saúde coletiva, Rio de Janeiro, v. 12, n. 1, Mar. 2007.

PERFARM. Agricultura no Brasil: evolução e estratégias adotadas. AGOSTO 7, 2017. Disponiel em http://blog.perfarm.com/agricultura-no-brasil/

Pesticide Exposure Among Pregnant Women Living in Farmworker Households in Salinas, California. American Journal Of Industrial Medicine.v. 45, p.491-499, 2004.

PETARLI, G. B., et al. Exposição ocupacional a agrotóxicos, riscos e práticas de segurança na agricultura familiar em município do estado do Espírito Santo, Brasil. Rev. bras. saúde ocup., v. 44, 2019.

PIGNATI, W. A. et al. Distribuição espacial do uso de agrotóxicos no Brasil: uma ferramenta para a Vigilância em Saúde. Ciênc. saúde coletiva, Rio de Janeiro , v. 22, n. 10, p. 32813293, Oct. 2017.

PIGNATI, W.A.; MACHADO, J.M.H; CABRAL, J.F. Acidente rural ampliado: o caso das "chuvas" de agrotóxicos sobre a cidade de Lucas do Rio Verde - MT. Cien Saude Colet, v/ 12, n. 1, p. 105-14, 2007.

PIGNATI, W.A.; MACHADO, J.M.H. O agronegócio e seus impactos na saúde dos trabalhadores e da população do estado de Mato Grosso. In: MINAYO, C.G; Machado, J. M.H.; Pena, P. G. L. Saúde do trabalhador na sociedade brasileira contemporânea. Rio de Janeiro, Editora Fiocruz, 2011. p.245-272.

PIRES, D. X.; CALDAS, E. D.; RECENA, M. C. Uso de agrotóxicos e suicídios no Mato Grosso do Sul, Brasil. Caderno de Saúde Pública. Rio de Janeiro, v.21, n.2, p.598-605, marabr, 2005

POLIT, D. F. Assessing measurement in health: beyond reliability and validity. Int J Nurs Stud., v. 52, n. 11, p. 1746-53, 2015.

POLIT, D. F.; BECK, C.T. Fundamentos de pesquisa em enfermagem: métodos, avaliação e utilização. 7 ed. Porto Alegre: Artmed; 2011.

POLIT, D. F.; BECK, C.T. The content validity index: are you know what's being reported? Critique and recommendations. Res Nurs Health., v. 29, n. 5, p. 489-97, 2006.

POMIECINSKI, F. et al. Estamos vivendo uma epidemia alimentar? Rev. bras. promoç. saúde (Impr.), v. 30, n. 3, p. 1-3, 2017. 
PRAXEDES, M.F.S. et al. Cross-cultural Adaptation of the Oral Anticoagulation Knowledge Test to the Brazilian Portuguese. Cienc Saúde Coletiva., v. 22, n. 5, p. 1615-29, 2017.

PRIORI, A.; POMARI, L. R.; AMÂNCIO, S.M.; IPÓLITO, V.K. A modernização do campo e o êxodo rural. In A. Priori, L. R. Pomari, S. M. Amâncio, \& V. K. Ipólito. (Orgs.), História do Paraná: séculos XIX e XX (pp. 115-127). Maringá: Eduem, 2012

RAMUNDO STADUTO, J. A.; ALVES NASCIMENTO, C.; DE SOUZA, M.. Ocupações e renda das mulheres e homens no rural do estado do Paraná, Brasil: uma perspectiva de gênero. Cuad. Desarro. Rural [online]., v. 10, n. 72, p. 91-115, 2013. Disponível em: $<$ http://www.scielo.org.co/scielo.php?script=sci_arttext\&pid=S0122$14502013000300006 \& \operatorname{lng}=$ en $\& n r m=$ iso $>$. Acesso em 03 de maio de 2020.

RAYMUNDO, V. Construção e validação de instrumentos: um desafio para a Psicolinguística. Letras de Hoje, Porto Alegre, v. 44, n. 3, p. 86-93, jul./set. 2009.

RECENA, et al. Exposição Pesticidas em Culturama, Brasil-Conhecimento, atitudes e práticas. Environ. Res. 2006, v.102,p.230-236.

RECENA, et al. Exposição Pesticidas em Culturama, Brasil-Conhecimento, atitudes e práticas. Environ. Res., v.102, p.230-236, 2006.

RECENA, M. C. P.; CALDAS, E. D. Percepção de risco, atitudes e práticas no uso de agrotóxicos entre agricultores de Culturama, MS. Rev. Saúde Pública, São Paulo, v. 42, n. 2, p. 294-301, Abril de 2008.

REICHENHEIM, M. E.; MORAES, C. L. Operacionalização de adaptação transcultural de instrumentos de aferição usados em epidemiologia. Rev. Saúde Pública, São Paulo, v. 41, n. 4, p. 665-673, Agos. 2007.

RIACH, K.E. Measurement of health outcomes: reliability, validity and responsiveness. $\mathbf{J}$ Prosthet Orthot., v.18, n. 1s, p. 8-12, 2006.

RIBEIRO JUNIOR, M.A.F.; CAMPOS, T.; LIMA, D.S.; MARTTOS JR, A.C.; PEREIRA, B.M. O cirurgião de trauma e emergência na era da pandemia de COVID-19. Rev Col Bras Cir., v. 42, 2020

RIBEIRO, D. R. B. A relação entre o uso de agrotóxico e a saúde respiratória dos trabalhadores rurais. Universidade Federal do Triângulo Mineiro . Uberaba, 2014. 37f.Monografia (Especialização em Atenção Básica em Saúde da Família).

RIBEIRO, M.G; et al. Yonamine, as práticas de segurança e saúde no trabalho entre ROACH, K.E. Measurement of health outcomes: reliability, validity and responsiveness. $\mathbf{J}$ Prosthet Orthot., v. 18, n. 1, p. 8-12, 2006.

ROBERTS, P.; PRIEST, H. Reliability and validity in research. Nurs Stand., v. 20, n.44, p. 41-5, 2006.

ROCHA, T. A. L. C. G.; OLIVEIRA, F. N.. Segurança e Saúde do Trabalho: Vulnerabilidade e percepção de riscos relacionados ao uso de agroquímicos em um pólo de fruticultura 
irrigada do Rio Grande do Norte. Gest. Prod., São Carlos , v. 23, n. 3, p. 600611, Sept. 2016.

ROS, J. R. Falsificação e contrabando de agrotóxicos: a sociedade perde a saúde, o país perde o respeito. V Congresso Brasileiro de Algodão - 29 de agosto a 01 de setembro de 2005.

ROSANO, A. et al. Infant mortality and congenital anomalies from 1950 to 1994: an international perspective. J. Epidemiol. Community Health, v. 54, n. 9, p. 660-666, 2000.

RUBIO, D. M., BERG-WEGER, M., TEBB, S. S., LEE, S., \& RAUCH, S. Objectifying content validity: Conducting a content validity study in social work research. Social Work Research,. v. 27, n. 2, p. 94-105, 2003. Disponível em:

http://swr.oxfordjournals.org/content/27/2/94.short. Acesso em 28 de junho de 2020.

SÁ, I. M. de B.; CRESTANA, S. Os caminhos do câncer na agricultura: desafios de uma abordagem em saúde ambiental. In: ESPÍNDOLA, E. WENDLAND, E. Bacias hidrográficas: diversas abordagens em pesquisa. São Carlos: RIMA, 2004. p. 381-

SAAVEDRA, J.S. CESAR, J.A. Uso de diferentes critérios para avaliação da inadequação do pré-natal: um estudo de base populacional no extremo Sul do Brasil. Cad Saúde Pública, v. 31, n. 5, p. 1003-14, 2015.

SALAZAR-GARCIA F.; et al. Reproductive effects of occupational DDT exposure among male Malaria control workers. Environmental Health Perspectives, v. 112, n. 5, p. 542-547, 2004.

SALMOND, S.S. Evaluating the Reliability and Validity of Measurement Instruments. Orthop Nurs., v. 27, n. 1, p. 28-30, 2008.

SANCEWICZ-PACH, K. et al. Acute pesticides poisonings in pregnant women. Przeglad lekarski, v. 54, n. 10, p. 741-744, 1997.

SANINE, P. R., et al . Atenção ao pré-natal de gestantes de risco e fatores associados no Município de São Paulo, Brasil. Cad. Saúde Pública, Rio de Janeiro, v. 35, n. 10, 2019.

SANINE, P.R.; CASTANHEIRA, E.R.L. Explorando nexos entre a construção social da criança e as práticas de saúde. Hist Ciênc Saúde-Manguinhos, v. 25, p. 199-215, 2018.

SANTANA, C. M.et al. Exposição ocupacional de trabalhadores rurais a agrotóxicos. Cad. saúde colet., Rio de Janeiro, v. 24, n. 3, p. 301-307, Sept. 2016.

SANTANA, V. S.; MOURA, M. C. P.; NOGUEIRA, F. F. Mortalidade por intoxicação ocupacional relacionada a agrotóxicos, 2000-2009, Brasil. Rev. Saúde Publica. V. 47, n.3, p. 598-606, 06/2013.

SANTOS NETO, E. T.; ALVES, K.C.G.; ZORZAL, M.; LIMA, R. C.; D. Políticas de saúde materna no Brasil: os nexos com indicadores de saúde materno-infantil. Saude soc. [online]., v.17, n. 2, p. 107-119, 2008. 
SÃO PAUlO (Cidade). Prefeitura do Município. Mãe Paulistana [Internet]. São Paulo; 2008 [citado 2008 nov. 19]. Disponível em:

$<$ http://ww2.prefeitura.sp.gov.br/secretarias/saude/mae_paulistana/estrutura.asp $>$. Acesso em: maio de 2018.

SAVOY, V.L.T. Classificação dos Agrotóxicos (palestra). Instituto Biológico, Centro de Pesquisa e Desenvolvimento em Proteção Ambiental. Biológico, São Paulo, v. 73, n.1, p.9192, jan/jun., 2011.

SCHABARUM, J. C.; TRICHES, R. M. Aquisição de Produtos da Agricultura Familiar em Municípios Paranaenses: análise dos produtos comercializados e dos preços praticados. Rev. Econ. Sociol. Rural [online], v.57, n.1, p.49-62, 2019.

SERRUYA, S. J.; LAGO, T. D. G.; CECATTI, J. G. O panorama da atenção pré-natal no Brasil e o Programa de Humanização do Pré-natal e Nascimento. Rev. Bras. Saude Mater. Infant., Recife, v. 4, n. 3, p. 269-279, Set. 2004 . Disponível em: $<$ http://www.scielo.br/scielo.php?script=sci_arttext\&pid=S1519$38292004000300007 \& \operatorname{lng}=\mathrm{en} \& n r m=\mathrm{iso}>$. Acesso em: maio de 2018.

SIJTSMA, K. On the use, the misuse, and the very limited usefulness of Cronbach's alpha. Psychometrika. 2009 Mar;74(1),107-20.

SILBERGELD, E.K.; PATRICK, T.E. Environmental exposures, toxicologic mechanisms, and adverse pregnancy outcomes. American Journal of Obstetrics and Gynecology, v. 192, n. supl 11, p.21, 2005.

SILVA DUTRA, L.; FERREIRA, A.P. Associação entre malformações congênitas e utilização de agrotóxicos em monoculturas no Paraná, Brasil. Saúde em Debate., v. 41, n.2, p. 241-53, 2017.

SILVA, J. M.; NOVATO-SILVA, E.; FARIA, H. P. et al. Agrotóxico e trabalho: uma combinação perigosa para a saúde do trabalhador rural. Ciência e saúde coletiva, vol.10, no.4, p.891-903. 2005.

SILVEIRA, M. F.; et al. Propriedades psicométricas do WHOQOL-HIV Bref para avaliação da qualidade de vida. Psico-USF, vol.24, n.3, pp.475-487, 2019.

SILVEIRA, M.F.; BARROS, A.J.D.; SANTOS, I.S.; MATIJASEVICH, A. VICTORA, C.G. Socioeconomic differentials in performing urinalysis during prenatal care. Rev Saúde Pública, v. 42, n. 3, p. 389-95, 2008.

SILVERIO, A. C. P. et al. Avaliação da Atenção Primária à Saúde para trabalhadores rurais expostos a pesticidas. Rev. Saúde Pública, v. 54, 2020.

SINDAG - Sindicato Nacional da Indústria de Produtos para Defesa Agrícola. Salvador, 2005.

SIQUEIRA, D. F. et al. Qualidade de vida de trabalhadores rurais e agrotóxicos: um estudo com o whoqol-bref. Rev. bras. ciênc. saúde, v. 17, n.2, p. 139-148, 2013. 
SIQUEIRA, D. F. et al. Qualidade de Vida de Trabalhadores Rurais e Agrotóxicos: uma Revisão Sistemática. Revista Brasileira de Ciências da Saúde Rural. v. 16, n. 2, p. 266, 2012.

SIQUEIRA, S. L.; KRUSE, M. H. L. Agrotóxicos e saúde humana: contribuição dos profissionais do campo da saúde. Rev. esc. enferm. USP [online]., v. 42, n.3, p. 584-590, 2008. disponível em: $<$ http://www.scielo.br/scielo.php?script=sci_arttext\&pid=S0080$62342008000300024 \& \operatorname{lng}=\mathrm{en} \& \mathrm{nrm}=\mathrm{iso}>$. Acesso em 20 de maio de 2020.

SCHMIDT, Letícia Petersen et al.Adaptação para língua portuguesa do questionário Tinnitus Handicap Inventory: validade e reprodutibilidade. Rev. Bras. Otorrinolaringol., São Paulo, v.72, n. 6, p. 808-810, dez.2006.

SOARES, W. L.; PORTO, M. F.S. Uso de agrotóxicos e impactos econômicos sobre a saúde. Rev Saude Publica; v. 46, n.2, p. 209-217, abr. 2012.

SOUSA, E.K.S., et al. Elaboração e validação de uma tecnologia educacional acerca da violência contra a mulher. Esc. Anna Nery [online]., v. 24, n. 4, 2020. Disponível em: $<$ http://www.scielo.br/scielo.php?script=sci_arttext\&pid=S1414$81452020000400201 \& \operatorname{lng}=\mathrm{en} \& n \mathrm{~nm}=\mathrm{iso}>$. Acesso em 20 de maio de 2020.

SOUSA, R. D.; et al. Apresentação de Software para Pós-processamento de Curvas de Deformação Cardíaca: D-Station. Arq. Bras. Cardiol., v.114, n.3, pp.496-506, 2020.

SOUZA JUNIOR, W.; BALDISSERA, J. F.; BERTOLINI, G. R. F.. Análise de opções reais aplicada na diversificação da produção rural no estado do Paraná. Rev. Econ. Sociol. Rural , v.57, n.2, p.253-269, 2019

SOUZA, A. G. Confiabilidade e validade de questionários. Epidemiol. Serv. Saúde. Brasília, 26(3): 649-659, 2017.

SOUZA, A.C.; ALEXANDRE, N.M.C.; GUIRARDELLO, E. B. Propriedades psicométricas na avaliação de instrumentos: avaliação da confiabilidade e da validade. Epidemiol. Serv. Saude, v. 26, n. 3, p. 649-659, 2017.

SOUZA, E. L. V. et al . Uso dos equipamentos de proteção individual em unidade de terapia intensiva. Rev. Enf. Ref., Coimbra, v. serIII, n. 4, jul. 2011.

SOUZA, G. S. et al. Presença de agrotóxicos na atmosfera e risco à saúde humana: uma discussão para a Vigilância em Saúde Ambiental. Ciênc. saúde coletiva, Rio de Janeiro , v. 22, n. 10, p. 3269-3280, Oct. 2017.

SPANEVELLO, R. A situação na transmissão do patrimônio na agricultura familiar. En Fazendo Gênero 8, Corpo, violência e poder. [CD-Rom]. Florianópolis: Anais- UFSC, 2008.

SPERBER, A. Translation and validation of study instruments for cross-cultural research.

Gastroenterology, s.1., v. 126, p. 124-128, 2004.

STANDIFER, S. H. The susceptibility of the fetus and child to chemical pollutants. Industrial and agricultural chemicals. Pediatrics, v. 53, p. 843-4, 1974. 
STREINER, D.L. Starting at the beginning: an introduction to coefficient alpha and internal consistency. J Pers Assess., v. 80, n.1, p. 99-103, 2003.

STREINER, D.L.; KOTTNER, J. Recommendations for reporting the results of studies of instrument and scale development and testing. J Adv Nurs., v. 70, n. 9, p. 1970-9, 2014.

SUZUKI, M.; MURAI, N. Fetal diseases caused by environmental polltuion. Sanfujinka no jissai. Practice of gynecology and obstetrics, v. 20, n. 10, p. 951, 1971.

TALBOT, A. R.; FU, C. C.; HSIEH, M. F. Paraquat intoxication during pregnancy: a report of 9 cases. Veterinary and human toxicology, v. 30, n. 1, p. 12-17, 1988.

TEIXEIRA, J. R. B. et al. Utilização dos equipamentos de proteção individual por mototaxistas: percepção dos fatores de risco e associados. Cad. Saúde Pública, Rio de Janeiro, v. 30, n. 4, Apr. 2014.

TERWEE, C.B.; et al. Quality criteria were proposed for measurement properties of health status questionnaires. J Clin Epidemiol., v. 10, n. 1, p. 34-42, 2007.

THIES, V. F. et al. Potencial das compras públicas como mercado para aagricultura familiar - uma análise do PNAE entre 2011-2014. In: $54^{\circ}$ Congresso da sociedade Brasileira de Economia, Administração e Sociologia Rural. Maceió-AL, 14 a 17 de agosto de 2016.

TINOCO, H. C., et al. Percepção de risco no uso do equipamento de proteção individual contra a perda auditiva induzida por ruído. Gest. Prod., v.26, n.1, 2019.

TOMASCHEWSKI-BARLEM, J. G. et al. Adaptação transcultural e validação da Escala Protetora de Defesa de Enfermagem para enfermeiros brasileiros. Rev. Latino-

Am. Enfermagem, Ribeirão Preto, v. 23, n. 4, p. 669-676, Agos.2015.

VALLE, S.; TELLES, J.L. (orgs). Bioética e Biorrisco. Rio de Janeiro: Interciência, 2003, $417 \mathrm{p}$.

VAN GELDER, M.M.; BRETVELD, R.W.; ROELEVELD, N. Webbased questionnaires: the future in epidemiology? Am J Epidemiol, v. 172, n. 11, p. 1292-8, Dez. 2010.

VEGA, C.E.P.; SOARES, V.M.N.; NARS, A.M.L.F. Mortalidade materna tardia: comparação de dois comitês de mortalidade materna no Brasil. Cad Saúde Pública, V.33, 2017.

VEIGA, M. M. et al. A contaminação por agrotóxicos e os Equipamentos de Proteção Individual (EPIs). Rev. bras. saúde ocup, São Paulo , v. 32, n. 116, Dec. 2007.

VELOSO, T. Valor Econômico: Produtividade Agrícola Brasileira cresceu 37 vezes em 35 anos. Valor. [Online] 1, 13 de junho de 2013. Disponível em:

http://www.valor.com.br/agro/3160554/produtividade-agricola-brasileira-cresceu-37-vezesem-35-anos. Acesso em 25 de maio de 2018. 
VENANCIO SI, TOMA TS, BUCCINI GS, SANCHES MTC et al. Anquiloglossia e aleitamento materno: evidências sobre a magnitude do problema, protocolos de avaliação, segurança e eficácia da frenotomia. Parecer Técnico-Científico. Instituto de Saúde. São Paulo, 2015.

VENANCIO, S.I.; et al. Efetividade da Estratégia Saúde da Família sobre indicadores de saúde da criança no Estado de São Paulo. Rev Bras Saúde Mater Infant, v. 16, p. 283-93, 2016.

VICTORA, C.G.; BARROS, F.C. Infant mortality due to perinatal causes in Brazil: trends, regional patterns and possible interventions. Sao Paulo Medical Journal. v.119, . 33-42, 2001 .

VIELLAS, E.F; et al. Assistência pré-natal no Brasil. Cad Saúde Pública., v.30, n. 1, p. 85$100,2014$.

VIERO, C. M. et al. Sociedade de risco: o uso dos agrotóxicos e implicações na saúde do trabalhador rural. Esc. Anna Nery, Rio de Janeiro, v. 20, n. 1, p. 99-105, Mar. 2016.

WATKINS, C.; DANIELS, L.; JACK, C.; DICKINSON, H.; VAN DEN BROEK, M. Accuracy of a single question in screening for depression in a cohort of patients after stroke: comparative study. BMJ., v. 323, n. 7322, p. 1159, nov 2001.

WEICHENTHAL, S.; MOASE, C.; CHAN, P. A review of pesticide exposure and cancer incidence in the agricultural health study cohort. Ciênc. saúde coletiva, Rio de Janeiro, v. 17, n. 1, p. 255-270, Jan. 2012.

WILKINSON, J. Transformações e perspectivas dos agronegócios brasileiros. R. Bras. Zootec., Viçosa, v. 39, supl. spe, p. 26-34, julho de 2010. Disponível em $<$ http://www.scielo.br/scielo.php?script=sci_arttext\&pid=S1516-

$35982010001300004 \& \operatorname{lng}=$ en\&nrm=iso $>$. Acesso em 30 de junho de 2020.

WORD HEALTH ORGANIZATION (WHO). Advocacy, communication and social mobilization for TB control: a guide to developing knowledge, attitude and practice surveys. Geneva, 2008.

WYND, C.A.; SCHMIDT, B.; SCHAEFER, M.A.; Two quantitative approaches for estimating content validity. West J Nurs Res, v. 25, n. 5, p. 508-518, 2003.

XIANG H., NUCKOLS J.R., STALLONES L. A Geographic Information Assessment of Birth Weight and Crop Production Patterns around Mother's Residence. Environmental Research, v. 82, p. 160-167, 2002.

YAN S.M. et al. Relationship between pesticide exposure and adverse pregnancy outcomes among famers: a meta-analysis. Zhonghua Lao Dong Sheng Zhi Wei Ye Bing Za Zhi. China, v. 30, n. 11, p. 859-62, 2012.

ZANCHETTA, M. S., et al. Brasil-Canadá: Lançando Sementes Através De Consulta Comunitária sobre o enfrentamento da violência contra a mulher. Esc. Anna Nery, Rio de Janeiro, v. 24, n. 3, 2020. 
ZANCHETTA, S., et al. Cross-cultural adaptation of the Amsterdam inventory for auditory disability and handicap to Brazilian Portuguese. Braz. j. otorhinolaryngol., v.86, n.1, p. 3$13,2020$.

ZUIDGEEST, M.; et al. A comparison of a postal survey and mixed-mode survey using a questionnaire on patients' experiences with breast care. J Med Internet Res, v. 13, n. 3, p. e68, Set. 2011. 
Anexos 

ANEXOS

ANEXO A - PARECER DE APROVAÇÃO DO COMITÊ DE ÉTICA

\section{HOSPITAL DO TRABALHADOR/SES/PR}

\section{PARECER CONSUBSTANCIADO DO CEP}

Elaborado pela Instituição Coparticipante

\section{DADOS DO PROJETO DE PESQUISA}

Título da Pesquisa: VALIDAÇÃO TRANSCULTURAL DO PROTOCOLO CAP ¿ ¿CONHECIMENTO ATITUDES E PRÁTICAS¿ EM GESTANTES EXPOSTAS A AGROTÓXICOS

Pesquisador: Karlla Cassol

Área Temática:

Versão: 1

CAAE: 69618817.4 .3001 .5225

Instituição Proponente: secretaria de estado da saude do parana

Patrocinador Principal: Financiamento Próprio

\section{DADOS DO PARECER}

Número do Parecer: 3.422 .972

\section{Apresentação do Projeto:}

Projeto Intitulado: Validação Transcultural do Protocolo CAP (Conhecimento, Atitudes e Práticas) em gestantes expostas a agrotóxicos. Trata-se de uma emenda deste projeto aprovado pelo CEP da Fundação Assis Gurgacz, adicionando uma Instituição coparticipante, sendo esta a secretaria de Saúde do Estado do Paraná, respondendo pelas $10^{\mathrm{a}}$ e $4^{\mathrm{a}}$ Regionais de Saúde do estado do Paraná.

A pesquisa tem como proposta validar transculturalmente na língua portuguesa 0 instrumento CAP (Conhecimento, Atitudes e Práticas - CASSOL, MAGNI, 2015.) O questionário

CAP aborda o conhecimento de gestantes sobre agrotóxicos, as atitudes sobre o uso desses produtos, e as práticas para o uso seguro dos mesmos. Trata-se de um estudo analítico observacional transversal, com análise quantitativa dos dados.

\section{Objetivo da Pesquisa:}

Realizar a validação do Questionário CAP - Conhecimento, atitudes e práticas em populações de gestantes expostas a agrotóxicos do Paraná.

\section{Avaliação dos Riscos e Benefícios:}

A presente pesquisa não gera riscos físicos aos participantes, mas é passível de riscos de constrangimento e/ou psicológicos aos participantes da pesquisa, quanto à reflexão dos conhecimentos empíricos, no entanto, sendo difícil mensura-los. Caso apresente-se necessário, os indivíduos serão encaminhados ao setor de psicologia mais próximo de sua região.

\footnotetext{
Endereço: Hospital do Trabalhador Avenida República Argentina, 4406 - Novo Mundo - 81.050-000 - Curitiba - PR 41 Bairro: Novo Mundo CEP: $81.050-000$ 


\section{HOSPITAL DO TRABALHADOR/SES/PR}

PARANÁ

Continuaçă̊o do Parecer: 3.422 .972

Os benefícios relacionados a esta pesquisa ainda são difíceis de mensurar, visto que poderão ser notados a longo prazo, mas podem repercutir positivamente em ações de promoção e prevenção da saúde da mulher gestante agricultora e seu filho.

\section{Comentários e Considerações sobre a Pesquisa:}

A pesquisa enviada a este CEP Coparticipante possui relevância social e justifica-se uma vez que visa verificar as condições de exposição de gestantes aos agrotóxicos, estes que são utilizados em todos os cultivares.

\section{Considerações sobre os Termos de apresentação obrigatória:}

Os termos obrigatórios foram corretamente anexados e ESTÃO DE ACORDO com os critérios éticos exigidos. As autorizações estão assinadas e carimbadas, o TCLE contempla todos os itens exigidos, sendo claros, objetivos e informativos quanto aos procedimentos que serão realizados durante a coleta de dados, bem como as garantias éticas aos participantes.

\section{Recomendações:}

Verificar as opções de respostas na seção 4, item 3; Seção 5, item 12, subitem "h": corrigir a palavra tempo; seção 6, item "d": o valor do salário mínimo está correto?; Seção 8, item "c" tem como incluir opções de sem conhecimento ou sem resposta ou incluir opção pular para a próxima seção em alguma pergunta anterior (uma vez que o pai pode ser desconhecido); na seção 13, item "n", "p" e "r": definir o tempo (sugestão de alterar a primeira opção para até 3 meses após dar à luz e na segunda opção entre 3 e 6 meses após dar a luz);

Visto que as gestantes entrevistadas são potencialmente expostas ao risco, sugerimos incluir orientações de caráter educativo em relação ao mesmo, bem como eventual necessidade de encaminhamento a serviço de atenção especializada.

\section{Conclusões ou Pendências e Lista de Inadequações:}

Solicitamos que sejam apresentados a este CEP, relatórios semestrais e final, sobre o andamento da pesquisa, bem como informações relativas às modificações do protocolo, cancelamento, encerramento e destino dos conhecimentos obtidos, através da Plataforma Brasil.

\section{Considerações Finais a critério do CEP:}

Relembramos os autores que devem ser encaminhados como NOTIFICAÇÃO os seguintes assuntos:

- Relatórios parciais (semestrais), se for o caso

- Relatório final

- O trabalho concluido

- Comunicação de eventos adversos (se houverem)

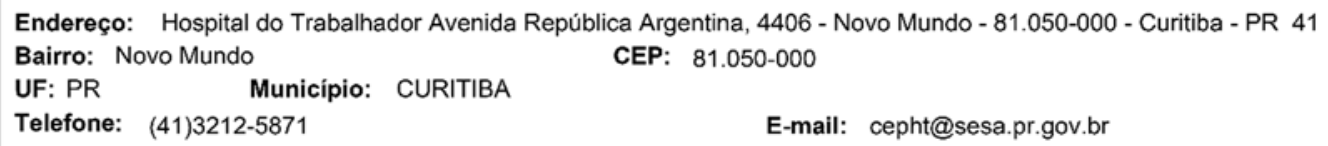




\section{HOSPITAL DO TRABALHADOR/SES/PR

Continuaçăo do Parecer: 3.422 .972

- Comunicação de início do trabalho e término do mesmo

Alterações no projeto devem ser submetidos como EMENDA.

Este parecer foi elaborado baseado nos documentos abaixo relacionados:

\begin{tabular}{|c|c|c|c|c|}
\hline Tipo Documento & Arquivo & Postagem & Autor & Situação \\
\hline $\begin{array}{l}\text { TCLE / Termos de } \\
\text { Assentimento / } \\
\text { Justificativa de } \\
\text { Ausência }\end{array}$ & TCLEREgional.docx & $\begin{array}{c}09 / 05 / 2019 \\
17: 05: 27\end{array}$ & Karlla Cassol & Aceito \\
\hline Outros & Anexo2KapPortugues.pdf & $\begin{array}{c}30 / 04 / 2019 \\
20: 45: 09\end{array}$ & Karlla Cassol & Aceito \\
\hline Outros & Anexo1Kaplngles.pdf & $\begin{array}{c}30 / 04 / 2019 \\
20: 44: 27\end{array}$ & Karlla Cassol & Aceito \\
\hline $\begin{array}{l}\text { Projeto Detalhado / } \\
\text { Brochura } \\
\text { Investigador }\end{array}$ & ProjetoDetalhado.docx & $\begin{array}{c}30 / 04 / 2019 \\
20: 36: 03\end{array}$ & Karlla Cassol & Aceito \\
\hline
\end{tabular}

Situação do Parecer:

Aprovado

Necessita Apreciação da CONEP:

Não

CURITIBA, 28 de Junho de 2019

Assinado por:

FABIO TERABE

(Coordenador(a))

Endereço: Hospital do Trabalhador Avenida República Argentina, 4406 - Novo Mundo - 81.050-000 - Curitiba - PR 41

Bairro: Novo Mundo

UF: PR

CEP: $81.050-000$

Telefone: (41)3212-5871

E-mail: cepht@sesa.pr.gov.br 


\section{ANEXO B - QUESTIONÁRIO KAP EM PORTUGUÊS}

\section{Questionário CAP para GESTANTES Expostas a Agrotóxicos}

() Gestante exposta a agrotóxicos

( ) Gestante NÂO exposta a agrotóxicos
Data entrevista

$$
\overline{\text { Dia }} \frac{}{\text { Mês }}-\overline{\text { Ano }}
$$

Qual a sua data de nascimento?

$$
\text { Dia } / \text { Mês Ano }
$$

Local onde vive (cidade e estado):

\section{Seção 1 - Informação ocupacional / Exercício físico}

\begin{tabular}{|c|c|c|}
\hline 1 & Você tem trabalhado desde que ficou grávida e/ou, desde seu último período menstrual? & $\begin{array}{l}\text { ( ) Sim } \\
\text { ( ) Não (ir para sessão 2) }\end{array}$ \\
\hline 2 & $\begin{array}{l}\text { Desde que você ficou grávida, neste emprego você tem feito algum trabalho agrícola? } \\
\text { (incluindo manuseio e aplicação de agrotóxicos, operação de trator ou equipamento, contramestre de trabalho } \\
\text { agrícola, trabalho no campo, trabalho interno } \mathrm{cm} \text { galpāo, trabalho } \mathrm{cm} \text { cstufa, ou cnccrando frutas) }\end{array}$ & $\begin{array}{l}\text { ( ) Sim } \\
\text { ( ) Não (ir para sessão 2) }\end{array}$ \\
\hline 3 & $\begin{array}{l}\text { Durante sua gestação, neste emprego você fez... } \\
\text { a. Manutenção de grande área agrícola ou vegetação (grama)? } \\
\text { b. Controle de cupins ou outras pragas em casa ou edifícios? } \\
\text { c. Trabalho em canavial ou outras plantas alimentícias onde você manuseia frutas ou } \\
\text { vegetais? }\end{array}$ & $\begin{array}{l}\text { ( ) } \operatorname{Sim}(\text { ) Não } \\
\text { ( ) } \operatorname{Sim} \text { ( ) Não } \\
\text { ( ) } \operatorname{Sim}(\text { ) Não }\end{array}$ \\
\hline 4 & Desde que você ficou grávida, você aplica ou aplicou agrotóxicos neste emprego? & ( ) $\operatorname{Sim}($ ) Não \\
\hline 5 & Desde que você ficou grávida, agrotóxicos são ou foram usados neste emprego? & ( ) Sim ( ) Não ( ) Não sei \\
\hline 6 & $\begin{array}{l}\text { Durante esta gestação, você tem usado frequentemente neste emprego... } \\
\text { a. Blusa de manga longa? } \\
\text { b. Luvas de algodão? } \\
\text { c. Chapéu ou algo cobrindo sua cabeça? } \\
\text { d. Lenço ou máscara para cobrir sua face? } \\
\text { e. Botas de borracha? }\end{array}$ & $\begin{array}{l}\text { ( ) } \operatorname{Sim} \text { ( ) Não } \\
\text { ( ) } \operatorname{Sim} \text { ( ) Não } \\
\text { ( ) } \operatorname{Sim} \text { ( ) Não } \\
\text { ( ) } \operatorname{Sim} \text { ( ) Não } \\
\text { ( ) } \operatorname{Sim} \text { ( ) Não }\end{array}$ \\
\hline
\end{tabular}

Agora, eu gostaria de lhe fazer algumas questões sobre os empregos atuais ou mais recentes que você tem realizado desde que ficou grávida.

\section{Seção 2 - Características da casa}

\begin{tabular}{|c|l|l|l|l|}
\hline & \multicolumn{2}{|c|}{ A: desde que você ficou grávida } & B: um ano antes de você ficar grávida \\
\hline 1 & $\begin{array}{l}\text { Com que frequência suas frutas e vegetais } \\
\text { tem sido lavados antes de você comê-los }\end{array}$ & $\begin{array}{l}\text { ( ) Sempre ( ) Frequentemente } \\
\text { () Algumas vezes ( ) Quase nunca } \\
\text { () Não Sei }\end{array}$ & $\begin{array}{l}\text { ( ) Sempre ( ) Frequentemente } \\
\text { () Algumas vezes ( ) Quase nunca } \\
\text { () Não Sei }\end{array}$ \\
\hline 2 & $\begin{array}{l}\text { Você tem comido frutas e vegetais vindos diretamente } \\
\text { do campo (não inclui aqueles de sua horta) }\end{array}$ & ( ) Sim ( ) Não ( ) Não sei & ( ) Sim ( ) Não ( ) Não sei \\
\hline
\end{tabular}

\section{Seção 3 - Limpeza da casa}

a. Com que frequência você limpa a sua casa?
( ) Diariamente ou mais
( ) Poucas vezes na semana () Uma vez na semana
( ) Quinzenalmente ( ) Uma vez ao mês ou menos
( ) Não sei

\section{Seção 4 - Uso de agrotóxicos}

Eu gostaria de lhe fazer algumas questōes sobre agrotóxicos que você tem usado dentro ou ao redor das casas onde tem morado desde que você ficou grávida.

\begin{tabular}{|c|c|c|}
\hline 1. & $\begin{array}{l}\text { Desde que você ficou grávida, agrotóxicos tem sido usados ao redor de suas casas } \\
\text { para matar as pragas? }\end{array}$ & ( ) Sim ( ) Não (ir para sessão 5) ( ) Não sei \\
\hline 2. & Estes agrotóxicos foram usados dentro ou fora de sua casa? & ( ) Dentro ( ) Fora ( ) Ambos ( ) Não sei \\
\hline 3. & Com que frequência estes agrotóxicos têm sido aplicados? & $\begin{array}{l}\text { ( ) Diariamente } \\
\text { ( ) Semanalmente } \\
\text { ( ) Uma a três vezes por mês } \\
\text { ( ) Mais que uma vez por mês } \\
\text { ( ) Não sei }\end{array}$ \\
\hline 4. & Você mesma aplica algum destes agrotóxicos? & ( ) Sim ( ) Não ( ) Não sei \\
\hline 5. & $\begin{array}{l}\text { Quando você aplicou os agrotóxicos, você usou algum tipo de proteção, como } \\
\text { roupa, luvas ou máscara? }\end{array}$ & $\begin{array}{l}\text { ( ) Sim ( ) Não ( ) Não sei } \\
\text { ( )Não apliquei agrotóxicos }\end{array}$ \\
\hline 6. & $\begin{array}{l}\text { Um ano antes de você ficar grávida, } \\
\text { Você mesma aplicava os agrotóxicos em casa? } \\
\text { Outra pessoa aplicou os agrotóxicos cm sua casa? }\end{array}$ & $\begin{array}{l}\text { () } \operatorname{Sim} \text { ( ) Não ( ) Não sei } \\
\text { ( ) Sim () Não ( ) Não sei }\end{array}$ \\
\hline
\end{tabular}
Agrotóxicos podem estar em sprays, bombas embalagens de veneno ou iscas para pragas, pó, giz, casa de baratas, armadilhas ou estacas. 
Seção 3 - Limpeza da casa

b. Com que frequência você limpa a sua casa?
( ) Diariamente ou mais
( ) Poucas vezes na semana ( ) Uma vez na semana
( ) Quinzenalmente ( ) Uma vez ao mês ou menos
( ) Não sei

Seção 4 - Uso de agrotóxicos

Eu gostaria de lhe fazer algumas questő́cs sobre agrotóxicos que você tem usado dentro ou ao redor das casas onde tem morado desde que você ficou grávida. Agrotóxicos podem estar em sprays, bombas embalagens de veneno ou iscas para pragas, pó, giz, casa de baratas, armadilhas ou estacas.

Seção 5 - Conhecimento, atitudes e práticas sobre agrotóxicos:

Agora, eu gostaria de lhe fazer algumas questóes gerais sobre saúde humana e pesticidas. Por favor, responda o melhor que você puder de acordo com seu conhecimento c opiniōes, assinalando um X.

\begin{tabular}{|c|c|c|c|}
\hline $\begin{array}{l}\text { 1. Eu acredito que as seguintes atitudes poderiam ser prejudiciais para } \\
\text { o meu feto }\end{array}$ & Sim & Não & Não sei \\
\hline \multicolumn{4}{|l|}{ a. Fumar cigarros } \\
\hline \multicolumn{4}{|l|}{ b. Comer frutas } \\
\hline \multicolumn{4}{|l|}{ c. Tomas bebidas alcoólicas } \\
\hline \multicolumn{4}{|l|}{ d. Usar agrotóxicos na casa } \\
\hline \multicolumn{4}{|l|}{ e. Usar agrotóxicos no trabalho } \\
\hline \multicolumn{4}{|l|}{ h. Usar suplementos alimentares } \\
\hline $\begin{array}{l}\text { 2. Exposição a agrotóxicos podem ter um efeito adverso ou impacto } \\
\text { sobre a saúde humana. }\end{array}$ & ( ) Concordo & $\begin{array}{l}\text { ( ) Não } \\
\text { concordo } \\
\text { (ii poraq,4) }\end{array}$ & ( ) Não sei \\
\hline $\begin{array}{l}\text { 3. Se sim, todos os agrotóxicos tem o mesmo efeito adverso sobre a } \\
\text { saúde do corpo humano? }\end{array}$ & ( ) $\operatorname{Sim}$ & ( ) Năo & ( ) Não sei \\
\hline \multicolumn{4}{|l|}{ b. Dos trabalhadores agrícolas que os aplicam } \\
\hline \multicolumn{4}{|l|}{ c. Outros trabalhadores agrícolas } \\
\hline \multicolumn{4}{|l|}{ d. Pessoas que consomem a colheita } \\
\hline \multicolumn{4}{|l|}{ e. $\quad$ Residentes do campo } \\
\hline \multicolumn{4}{|l|}{ f. Residentes das cidades e comunidades próximas da plantação } \\
\hline 5. Quais das seguintes vias são de ingestão de agrotóxicos? & Sim & Não & Não sei \\
\hline \multicolumn{4}{|l|}{ a. $\quad$ Respiração de agrotóxicos } \\
\hline \multicolumn{4}{|l|}{ b. Por mordida de mosquito } \\
\hline \multicolumn{4}{|l|}{ c. Por contato dos agrotóxicos com a pele } \\
\hline \multicolumn{4}{|l|}{ d. Ingerindo agrotóxicos } \\
\hline \multicolumn{4}{|l|}{ a. Usar equipamentos de proteção quando manusear os agrotóxicos } \\
\hline \multicolumn{4}{|l|}{ b. Usar luvas quando manusear os agrotóxicos } \\
\hline \multicolumn{4}{|l|}{ c. Lavar frutas e vegetais antes de comê-los } \\
\hline \multicolumn{4}{|l|}{ d. Cobrir boca e nariz quando sua mão estiver aplicando os agrotóxicos } \\
\hline \multicolumn{4}{|l|}{ e. Lavar as mãos em um riacho após aplicar agrotóxicos } \\
\hline f. Tomar banho imediatamente após aplicar agrotóxicos & & & \\
\hline g. Lavar as roupas utilizadas na plantação separadamente de outras roupas & & & \\
\hline $\begin{array}{l}\text { 9. De acordo com seu conhecimento, os sintomas de toxicidade por } \\
\text { agrotóxicos podem ser quais dos seguintes? }\end{array}$ & Sim & Não & Não sci \\
\hline a. $\quad$ Dor de cabeça & & & \\
\hline b. Lacrimejamento dos olhos & & & \\
\hline
\end{tabular}


c. Infarto / ataque cardíaco

d. Náusea / vômitos

e. Salivação excessiva

f. Tosse / frio (calafrio?) / dor no peito / falta de ar

g. Erupções na pele / irritação na pele / coceira

h. Dor abdominal / diarreia

i. Fraqueza muscular / fadiga / dor no corpo

\section{Você tem recebido treinamento sobre agrotóxicos?}

11. Se sim, por favor, responda o que segue:

a. Onde você recebeu treinamento ?

b. Quando você recebeu o último treinamento?

\begin{tabular}{|c|c|c|c|c|}
\hline c. Quais os tópicos que foram discutidos neste treinamento? & \multicolumn{2}{|l|}{ Sim } & Não & Não sei \\
\hline \multicolumn{5}{|l|}{ Envenenamento por agrotóxicos } \\
\hline \multicolumn{5}{|l|}{ Equipamento de proteção individual } \\
\hline \multicolumn{5}{|l|}{ Efeitos dos agrotóxicos sobre a saúde } \\
\hline \multicolumn{5}{|l|}{ Técnicas apropriadas de aplicação } \\
\hline \multicolumn{5}{|l|}{ Outros, especificar: Não tem como especificar } \\
\hline 12. Você concorda ou discorda com as seguintes declarações? & \multicolumn{2}{|c|}{ Concordo } & Discordo & Não sei \\
\hline \multicolumn{5}{|l|}{ a. Agrotóxicos protegem as pessoas de doenças relacionadas às pragas. } \\
\hline \multicolumn{5}{|l|}{ b. Agrotóxicos são venenosos } \\
\hline \multicolumn{5}{|l|}{ c. Agrotóxicos perigosos podem causar morte } \\
\hline \multicolumn{5}{|l|}{ d. Você pode fumar, comer ou beber durante a aplicação dos agrotóxicos } \\
\hline \multicolumn{5}{|l|}{$\begin{array}{l}\text { e. Usar uma grande quantidade de agrotóxicos, por somente um curto } \\
\text { período de tempo, não é prejudicial para a minha saúde. }\end{array}$} \\
\hline \multicolumn{5}{|l|}{$\begin{array}{l}\text { f. Usar uma grande quantidade de agrotóxicos, por somente um curto } \\
\text { período de tempo, não é prejudicial para a saúde do meu feto. }\end{array}$} \\
\hline \multicolumn{5}{|l|}{$\begin{array}{l}\text { g. Usar uma pequena quantidade de agrotóxicos, por um longo período de } \\
\text { tempo não é prejudicial para a minha saúde. }\end{array}$} \\
\hline \multicolumn{5}{|l|}{$\begin{array}{l}\text { h. Usar uma pequena quantidade de agrotóxicos, por um longo período de } \\
\text { tempo não é prejudicial para a saúde do meu feto }\end{array}$} \\
\hline \multicolumn{5}{|l|}{ i. Adultos são mais resistentes aos agrotóxicos do que crianças } \\
\hline \multicolumn{5}{|l|}{ j. Adultos são mais resistentes aos agrotóxicos do que bebês } \\
\hline \multicolumn{5}{|l|}{$\begin{array}{l}\text { k. Se eu comer ou beber próximo às áreas onde os agrotóxicos têm sido } \\
\text { aplicados, eu não estarei exposta a eles. }\end{array}$} \\
\hline \multicolumn{5}{|l|}{$\begin{array}{l}\text { 1. Se um agrotóxico é vendido no mercado, significa que é seguro e não há } \\
\text { problema em como ou por quem utilizá-lo. }\end{array}$} \\
\hline \multicolumn{5}{|l|}{$\begin{array}{l}\text { m. Um agrotóxico é efetivo somente se seu efeito pode ser visto } \\
\text { imediatamente após aplicação. }\end{array}$} \\
\hline \multicolumn{5}{|l|}{$\begin{array}{l}\text { n. Um agrotóxico é mais efetivo se é aplicado de acordo com a experiência } \\
\text { profissional e não necessariamente de acordo com a quantidade } \\
\text { recomendada. }\end{array}$} \\
\hline \multicolumn{5}{|l|}{ o. Cada pessoa que usa um agrotóxico é responsável por seu uso seguro. } \\
\hline \multicolumn{5}{|l|}{$\begin{array}{l}\text { p. Após usar agrotóxicos por um número de anos, uma pessoa pode } \\
\text { desenvolver uma imunidade a eles. }\end{array}$} \\
\hline \multicolumn{2}{|l|}{ 13. Quais das seguintes opções são potencias impactos dos agrotóxicos à saúde? } & Sim & Não & Não sei \\
\hline \multicolumn{5}{|l|}{ a. Envenenamento por agrotóxicos } \\
\hline \multicolumn{5}{|l|}{ b. Câncer } \\
\hline \multicolumn{5}{|l|}{ c. Obesidade } \\
\hline \multicolumn{5}{|l|}{ d. Aprendizagem lenta } \\
\hline \multicolumn{5}{|l|}{ e. Pele irritada } \\
\hline f. Tosse & & & & \\
\hline
\end{tabular}




\begin{tabular}{|c|c|c|c|}
\hline 14. Eu uso agrotóxicos em casa porque... & Sim & $\underset{\text { (le para q. 15) }}{\text { Não }}$ & Não sei \\
\hline \multicolumn{4}{|l|}{ a. Eles protegem minha casa e família dos mosquitos } \\
\hline \multicolumn{4}{|l|}{ b. Eles protegem minha casa e família de outros insetos } \\
\hline \multicolumn{4}{|l|}{ c. Eles protegem minha casa e família de roedores } \\
\hline \multicolumn{4}{|l|}{ d. Eles protegem minha casa e família de cupins } \\
\hline \multicolumn{4}{|l|}{ e. Eles protegem minha casa e família de outras pestes } \\
\hline \multicolumn{4}{|l|}{ f. Eles protegem minha casa e família de doenças } \\
\hline \multicolumn{4}{|l|}{ g. Eles conservam minha casa limpa } \\
\hline \multicolumn{4}{|l|}{ h. Um membro da família me disse para usar } \\
\hline \multicolumn{4}{|l|}{$\begin{array}{l}\text { i. Segui o aviso de um médico, enfermeiro, líder comunitário, voluntário de saúde ou } \\
\text { oficial do governo }\end{array}$} \\
\hline \multicolumn{4}{|l|}{ j. $\quad$ Outros, especificar: } \\
\hline 15. Eu uso agrotóxicos no trabalho porque... & Sim & $\underset{\text { (It para sussano }}{\text { Não }}$ & Não sei \\
\hline \multicolumn{4}{|l|}{ a. Eles matam os insetos que prejudicariam as plantaçỗes } \\
\hline \multicolumn{4}{|l|}{ b. Eles matam outras pestes que prejudicariam as plantaçôes } \\
\hline \multicolumn{4}{|l|}{ c. Eles mantém livres de bactérias o crescimento das plantações } \\
\hline \multicolumn{4}{|l|}{ d. Eles matam outras plantas indesejáveis } \\
\hline \multicolumn{4}{|l|}{ e. Eles fazem as plantações crescerem mais altas } \\
\hline f. Disseram-me para aplicá-los & & & \\
\hline g. Outros, especificar: & & & \\
\hline
\end{tabular}

\section{Seção 6 - Demografia}

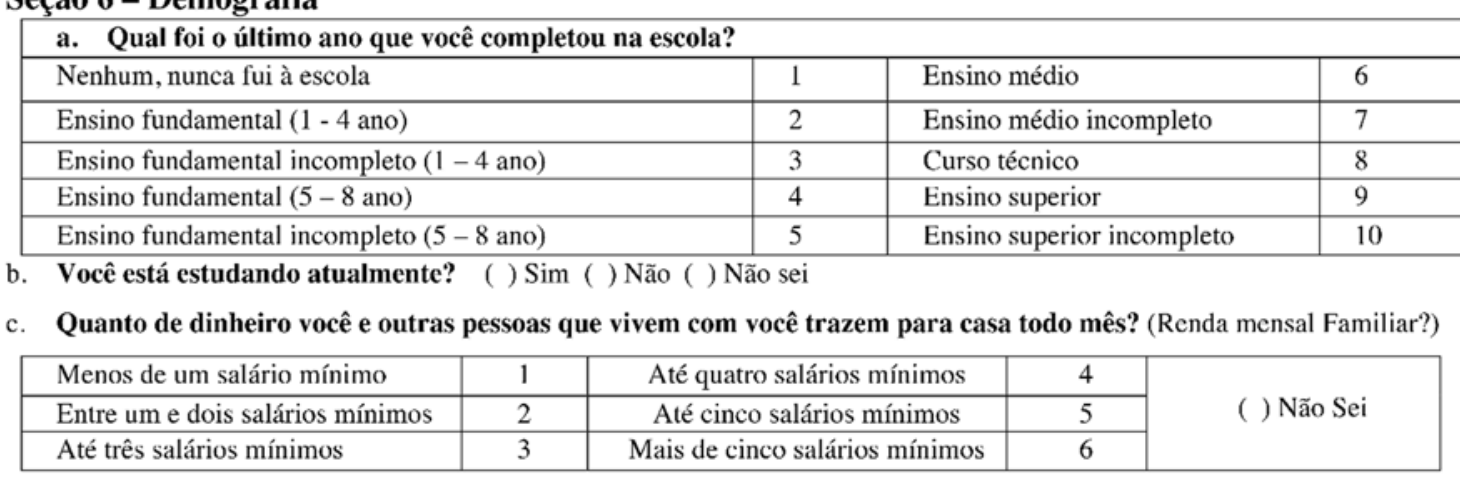

d. Pense no lugar que você vive, no alimento que você come e as coisas que você pode fazer ou comprar. Você acha que pode ter o suficiente disto com o que traz para casa?

( ) Sim, eu posso e tenho o suficiente para sobreviver

( ) Sim, eu posso e não tenho o suficiente para sobreviver

( ) Não sei
e. Qual a sua nacionalidade?
( ) Brasileira
( ) Estrangeira
( ) Não sei

\section{Seção 7. História médica}

Agora, eu gostaria de lhe fazer algumas questões sobre vitaminas que você toma ou tomou nos três meses antes da gestação até agora

a. Nos três meses antes de você ficar grávida, você se consultou ou tomou algum suplemento vitamínico?
( ) $\mathrm{Sim}$
( ) Não ( ) Não sei

b. Desde que você ficou grávida, tem feito alguma consulta ou tomado algum suplemento vitamínico?
( ) $\mathrm{Sim}$
( ) Não ( ) Não sei

\section{Seção 8. História gestacional}

a. Excluindo esta gestação, quantas vezes você ficou grávida? (Não importa o que aconteceu com a gestação)
( ) Nenhuma vez, essa é minha primeira gestação.
( ) 1 vez
( ) 2 vezes
( ) mais de 3 vezes.

b. Quantas crianças estão vivendo com você atualmente? crianças

( ) Não sei 
8.1 Demografia paternal
a. Qual a descendência de cor do pai do seu bebê?
( ) Branca ( ) Negra ( )Amarela ( ) Não sei
b. Qual a nacionalidade do pai do seu bebê?
( ) Brasileira ( ) Estrangeira ( ) Não sei

\begin{tabular}{|l|l|l|l|}
\hline \multicolumn{2}{|l|}{ c. Qual foi o último ano que o pai do seu bebê completou na escola? } & 6 \\
\hline Nenhum, nunca fui à escola & 1 & Ensino médio & 7 \\
\hline Ensino fundamental (1 - 4 ano) & 2 & Ensino médio incompleto & 8 \\
\hline Ensino fundamental incompleto (1 -4 ano) & 3 & Curso técnico & 9 \\
\hline Ensino fundamental (5 - 8 ano) & 4 & Ensino superior & 10 \\
\hline Ensino fundamental incompleto (5 - 8 ano) & 5 & Ensino superior incompleto & 1 \\
\hline
\end{tabular}

\section{Seção 9. Membros residentes na casa}

\begin{tabular}{|c|c|c|c|}
\hline Agora vamos falar um pouco sobre as pessoas que vivem com você. & Sim & $\begin{array}{c}\text { Não } \\
\text { (Ir para sessắo 10) }\end{array}$ & Não sei \\
\hline \multicolumn{4}{|l|}{ a. Alguma outra pessoa que vive com você trabalha na agricultura? } \\
\hline \multicolumn{4}{|l|}{$\begin{array}{l}\text { b. Alguma destas pessoas (incluindo você mesma) frequentemente usam seus } \\
\text { sapatos de trabalho dentro de sua casa? }\end{array}$} \\
\hline \multicolumn{4}{|l|}{$\begin{array}{l}\text { c. Alguma destas pessoas usam suas roupas regulares de trabalho em sua casa por } \\
\text { mais de meia hora antes de trocarem de roupa? }\end{array}$} \\
\hline \multicolumn{4}{|l|}{$\begin{array}{l}\text { d. Estas roupas de trabalho são mantidas separadamente das outras roupas da } \\
\text { família? }\end{array}$} \\
\hline $\begin{array}{l}\text { e. Estas roupas de trabalho são lavadas juntamente com as roupas da família ou } \\
\text { lavadas separadamente? }\end{array}$ & $\begin{array}{c}\text { Lavadas } \\
\text { juntamente } \\
(()\end{array}$ & $\begin{array}{l}\text { Lavadas } \\
\text { separadamente } \\
(\text { ( ) }\end{array}$ & \\
\hline $\begin{array}{l}\text { f. São guardadas embalagens ou sacos plásticos de agrotóxicos do trabalho ao redor } \\
\text { da casa onde você vive agora? }\end{array}$ & & & \\
\hline
\end{tabular}

\section{Seção 10. Animais domésticos}

Eu gostaria de saber sobre os animais que vivem dentro de sua casa desde que você ficou grávida. Por favor, inclua cachorros, gatos, pássaros ou outros animais peludos que pertencem à você ou a alguém que vive dentro de sua casa, incluindo pessoas que não são seus parentes.

a. Desde que você ficou grávida, você tem aplicado shampoo para pulgas e carrapatos, pomada ou talco em seus animais?

$\begin{array}{lll}\text { ( ) } \operatorname{Sim} & \text { ( ) Não ( ) Não sei }\end{array}$

b. Você usou luvas quando aplicou estes produtos?

$\begin{array}{lll}\text { ( ) } \operatorname{Sim} & \text { ( ) Não } & \text { ( ) Não sei }\end{array}$

Seção 11. Informação sobre hábitos pessoais - Agora, eu gostaria de lhe fazer algumas questões sobre seus hábitos para fumar.

a. Nos três meses antes de você ficar grávida, você fumou algum cigarro?

$\begin{array}{llll}\text { ( ) } \operatorname{Sim} & \text { ( ) Não ( ) Não sei }\end{array}$

b. Desde que você ficou grávida, você tem fumado algum cigarro?

$\begin{array}{lll}\text { ( ) } \operatorname{Sim} & \text { ( ) Não } & \text { ( ) Não sei }\end{array}$

Seção 12. Outras exposições e preocupações

a.Você sabe de algum outro efeito que os agrotóxicos ou outra exposição ambiental na região onde vive, que você ou sua família pode ter sofrido?
( ) Sim
( ) Não
( ) Não sei
Se sim, relate:

\section{Seção 13 Questões adicionais}

a.Há quanto tempo você vive nesta região?
( ) Vivo nessa região desde que nasci.
( ) Menos de 5 anos.
( ) Entre 5 a 10 anos.
( ) Entre 10 e 20 anos.
( ) Entre 20 e trinta anos.
() Mais de 30 anos.

b. A sua casa atual é próxima de uma área agrícola?

\begin{tabular}{|l|l|l|l|}
\hline Eu vivo em uma área agrícola & & Eu não vivo próximo de uma área agrícola $(>500 \mathrm{~m})$ & \\
\hline Eu vivo próximo de uma área agrícola $(<500 \mathrm{~m})$ & & Não sei & \\
\hline
\end{tabular}


c. Que benefícios médicos você tem tido para realizar o pré-natal?

\begin{tabular}{|l|l|l|l|c|}
\hline SUS & 1 & Atendimento privado & 4 & \multirow{2}{*}{ Não sei } \\
\cline { 1 - 4 } Convênio médico & 2 & Nenhum & 5 & ( ) \\
\hline Seguro social & 3 & Outro, especificar & 6 & \\
\hline
\end{tabular}

d. Que mês de gestação foi sua primeira visita ao pré-natal?
( ) Não sei
( ) Entre o primeiro e o terceiro mês de gestação
( ) Entre o quarto e o sexto mês de gestação
( ) Entre o sétimo e o nono mês de gestação.

e. Durante a sua gestação, até agora, quantas vezes você realizou o pré-natal?
( ) Não sei
( ) 1 a 3 vezes
( ) 3 a 6 vezes
( ) mais de 6 vezes

f. Durante sua gestação, você tem feito as consultas regularmente agendadas?
( ) Sim, em todas as consultas
( ) Sim, mas não na data do agendamento

( ) Não Se não, porque:

g. Você ainda trabalha diariamente?
( ) $\operatorname{Sim}$
( ) Não
( ) Não sei

h. Um ano atrás, você trabalhou?

( ) Sim (Ir para questão “j”)

( ) Não

i. Quando você parou de trabalhar?

( ) Antes que eu soubesse que estava grávida

( ) Após eu ter sabido que estava grávida (no

( ) Eu não parei de trabalhar mês de gestação porque

j. Qual a função no emprego?

( ) Eu tenho meu próprio negócio/ plantação/fazenda ( ) Eu sou empregada ( ) Outro, especificar

k. Quando você planejou parar de trabalhar?

( ) Quando o médico ordenar ou quando não pude mais trabalhar $\quad$ ( ) Eu trabalharei até dar à luz ( ) Não sei

I. Após dar à luz, você deseja trabalhar?
( ) $\mathrm{Sim}$
( ) Não
( ) Não sei

m. Se você planeja trabalhar após dar à luz, seu trabalho envolve agricultura?
( ) $\mathrm{Sim}$
( ) Não
( ) Não pretendo voltar a trabalhar

n. Quando você planeja começar a trabalhar novamente?
( ) Entre 3 meses após dar à luz.
( ) Entre 6 meses após dar à luz
( ) Não sei
( ) Não pretendo voltar a trabalhar
( ) Após 6 meses depois de dar à luz

o. Você planeja se mudar desta região?
( ) $\operatorname{Sim}$
( ) Não (ir para questão "q")
( ) Não sei

p. Quando você planeja se mudar desta região?
( ) Entre 3 meses após dar à luz
( ) Entre 6 meses após dar à luz
( ) Após 6 meses depois de dar à luz
( ) Não sei
( ) Não pretendo me mudar desta região

q. Você mesma amamentará o seu bebê?
( ) Sim (ir para questão "r")
( ) Não
( ) Não sei
Motivo: para "não" ou "Não sei “.

r. Por quanto tempo você amamentará ao seu bebê?
( ) 3 meses após dar à luz
( ) 6 meses após dar à luz
( ) Um ano após dar à luz
( ) Mais que um ano após dar à luz
( ) Não sei

\begin{tabular}{|c|c|c|}
\hline QUESTÕNS FINAIS & SIM & $\mathrm{NĀO}$ \\
\hline 1. Voce acredita que tem conhecimento adequado sobre os efeitos do & & \\
\hline 2. Voce acredita que tem atitudes adequadas frente aos agrotóxicos? & & \\
\hline 3. Voce acredita que possui praticas seguras sobre os agrotóxicos? & & \\
\hline
\end{tabular}



Apêndices 



\section{APÊNDICES \\ APÊNDICE A - TERMO DE CONSENTIMENTO LIVRE E ESCLARECIDO (TCLE)}

\section{TERMO DE CONSENTIMENTO LIVRE E ESCLARECIDO}

Nós. Karlla e Andrea, pesquisadores da Faculdade de Odontologia de Bauru da Universidade de São Paulo - FOB/USP, estamos convidando a senhora gestante a participar de um estudo intitulado "VALIDAÇÃO TRANSCULTURAL DO PROTOCOLO CAP “CONHECIMENTO ATITUDES E PRÁTICAS EM GESTANTES EXPOSTAS A AGROTÓXICOS”, que pretende verificar o seu conhecimento, suas atitudes e práticas frente aos agrotóxicos, pois, possivelmente você esta sendo expostas aos efeitos desses produtos, utilizados no local onde você vive e trabalha ou próximo dali. Essa pesquisa tem como proposta validar o questionário CAP, visando a efetivação do protocolo como um instrumento a ser usado por profissionais da saúde c para identificação dos fatores de risco que norteiam a temática agrotóxicos em gestantes, sendo necessário para isso a sua validação, também as respostas obtidas a partir desse questionário poderá contribuir para futuras intervenções.

O objetivo desta pesquisa é realizar a validação do questionário CAP (Conhecimentos, Atitudes c Práticas) $\mathrm{cm}$ populações de gestantes expostas a agrotóxicos no Parana.

Caso você participe da pesquisa, será necessário que você responda a um questionário, com questōes objetivas que tem pretensão de verificar seu conhecimento, suas atitudes e práticas frente aos agrotóxicos. O tempo previsto para a sua participação é de aproximadamente 15 minutos.

Alguns riscos podem relacionados ao estudo podem ser: embora essa pesquisa não gere riscos físicos a você, é possivel o risco de constrangimento e/ou psicológicos aos participantes da pesquisa, quanto à reflexão dos conhecimentos empíricos, no entanto, sendo difícil mensurá-los, . Caso apresente-se necessário, você será encaminhada ao setor de psicologia mais próximo de sua região.

Os benefícios esperados com essa pesquisa são de longo prazo, mas podem repercutir positivamente em ações de promoção e prevenção da saúde da mulher gestante exposta a agrotóxicos e seu filho. No entanto, nem sempre você será diretamente beneficiado com o resultado da pesquisa, mas poderá contribuir para o avanço científico.Os resultados desta pesquisa poderão ser apresentados em seminários, congressos e similares, entretanto, os dados/informações obtidos por meio da sua participação serão confidenciais e sigilosos, não possibilitando sua identificação.

Os pesquisadores responsáveis por este estudo poderão ser contatados da seguinte maneira: Karlla Cassol, fonoaudióloga, docente em Fonoaudiologia - Endereço: Rua João Padilha, Bairro FAG - Cascavel, Paraná. Telefone: (45) 99812 5575. E-mail: karlla_cassol@ hotmail.com . Andrea Cintra Lopes, Docente na Faculdade de Odontologia de Bauru - Universidade de São Paulo - USP Departamento de Fonoaudiologia. Bauru- São Paulo - Endereçco para contato: +55(14) 9 8125-7464. Faculdade de Odontologia de Bauru. Universidade de São Paulo. Al. Octavio Pinheiro Brisola 9-75. Vila Universitária - Bauru - SP. Cep: 17012-901 - Fone: +55(0xx14) 32358332,E-mail: aclopes@usp.br

A sua participação neste estudo é voluntária e se você não quiser mais fazer parte da pesquisa poderá desistir a qualquer momento e solicitar que lhe devolvam o termo de consentimento livre e esclarecido assinado.

As informações relacionadas ao estudo poderão ser conhecidas por pessoas autorizadas, como o orientador dessa pesquisa (Andrea Cintra Lopes). No entanto, se qualquer informação for divulgada em relatório ou publicação, isto será feito sob forma codificada, para que a sua identidade seja preservada e seja mantida a confidencialidade.

As despesas necessárias para a realização da pesquisa (impressão de questionários, etc.) não são de sua responsabilidade e pela sua participação no estudo você não receberá qualquer valor $\mathrm{cm}$ dinheiro. Você terá a garantia de que problemas como: constrangimento c abalos psicológicos decorrentes do estudo serão tratados no centro psicológico mais próximo de sua região.

Quando os resultados forem publicados, não aparecerá seu nome, e sim um código.

Eu,

li esse termo de consentimento e

compreendi a natureza e objetivo do estudo do qual concordei em participar. A explicação que recebi menciona os riscos e benefícios. Eu entendi que sou livre para interromper minha participação a qualquer momento sem justificar minha decisão. Eu entendi e fui informado que serei atendido sem custos para mim se eu apresentar algum problema dos relacionados no item .

Eu concordo voluntariamente em participar deste estudo.

(Nome e Assinatura do participante da pesquisa ou responsável legal)

Local: ___ data ___ _ _ _ _

Declaro que obtive de forma apropriada e voluntária o Consentimento Livre e Esclarecido deste participante ou representante legal para a participação neste estudo.

Larlla Rassol

Karlla Cassol

(Pesquisadora Responsável)

Local:

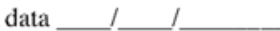




\section{APÊNDICE B - TABELA DE ANÁLISE}

Tabela 10 - Análise da consistência interna do Questionário CAP em gestantes do Grupo Expostas

\begin{tabular}{|c|c|c|c|c|}
\hline & $\begin{array}{l}\text { Média de escala se o } \\
\text { item for excluído }\end{array}$ & $\begin{array}{l}\text { Variância de escala se o } \\
\text { item for excluído }\end{array}$ & $\begin{array}{c}\text { Correlação de item } \\
\text { total corrigida }\end{array}$ & $\begin{array}{c}\text { Alfa de Cronbach se o } \\
\text { item for excluído }\end{array}$ \\
\hline $1.6 \mathrm{a}$ & 4478,90 & 23635224,99 & 0,683 & 0,906 \\
\hline $1.6 \mathrm{~b}$ & 4478,46 & 23638443,04 & 0,050 & 0,906 \\
\hline $1.6 \mathrm{c}$ & 4478,56 & 23637692,21 & 0,238 & 0,906 \\
\hline $1.6 \mathrm{e}$ & 4478,65 & 23640308,51 & $-0,398$ & 0,906 \\
\hline 3.1 & 4479,31 & 23639223,08 & $-0,248$ & 0,906 \\
\hline 4.2 & 4478,29 & 23635442,41 & 0,650 & 0,906 \\
\hline 4.3 & 4477,96 & 23635196,00 & 0,545 & 0,906 \\
\hline 4.4 & 4478,46 & 23637926,65 & 0,248 & 0,906 \\
\hline 4.5 & 3967,23 & 21073560,69 & 0,584 & 0,902 \\
\hline $4.6 \mathrm{a}$ & 4478,90 & 23635224,99 & 0,683 & 0,906 \\
\hline $4.6 \mathrm{~b}$ & 4478,96 & 23641690,59 & $-0,642$ & 0,906 \\
\hline $5.1 \mathrm{~h}$ & 4386,92 & 21442878,58 & 0,874 & 0,898 \\
\hline 5.3 & 4393,92 & 21388541,64 & 0,893 & 0,897 \\
\hline $5.4 \mathrm{c}$ & 4394,10 & 21387688,87 & 0,893 & 0,897 \\
\hline $5.4 \mathrm{~d}$ & 4411,15 & 23812464,25 & $-0,099$ & 0,909 \\
\hline $5.5 \mathrm{a}$ & 4394,10 & 21387688,87 & 0,893 & 0,897 \\
\hline $5.5 \mathrm{~b}$ & 4052,52 & 20870076,80 & 0,629 & 0,901 \\
\hline $5.5 \mathrm{c}$ & 4394,10 & 21387688,87 & 0,893 & 0,897 \\
\hline $5.5 \mathrm{~d}$ & 4377,04 & 21490931,06 & 0,779 & 0,899 \\
\hline $5.5 \mathrm{e}$ & 4394,10 & 21387688,87 & 0,893 & 0,897 \\
\hline $5.8 \mathrm{~d}$ & 4478,94 & 23638426,13 & 0,030 & 0,906 \\
\hline $5.8 \mathrm{e}$ & 4478,79 & 23639206,17 & $-0,131$ & 0,906 \\
\hline $5.8 \mathrm{f}$ & 4479,29 & 23635958,64 & 0,904 & 0,906 \\
\hline $5.9 b$ & 4479,31 & 23638706,69 & $-0,050$ & 0,906 \\
\hline $5.9 \mathrm{c}$ & 3977,65 & 21034273,09 & 0,601 & 0,901 \\
\hline $5.9 \mathrm{e}$ & 4479,37 & 23638677,49 & $-0,076$ & 0,906 \\
\hline $5.9 \mathrm{f}$ & 4137,87 & 23179864,90 & 0,064 & 0,912 \\
\hline $5.9 \mathrm{~g}$ & 4394,10 & 21387688,87 & 0,893 & 0,897 \\
\hline $5.9 \mathrm{~h}$ & 4479,00 & 23640621,76 & $-0,429$ & 0,906 \\
\hline $5.9 \mathrm{i}$ & 4479,29 & 23638809,39 & $-0,081$ & 0,906 \\
\hline $5.12 \mathrm{a}$ & 4478,79 & 23639206,17 & $-0,131$ & 0,906 \\
\hline $5.12 \mathrm{e}$ & 4393,21 & 21390048,68 & 0,893 & 0,897 \\
\hline $5.12 f$ & 4478,50 & 23641088,45 & $-0,801$ & 0,906 \\
\hline $5.12 \mathrm{~g}$ & 4478,50 & 23641088,45 & $-0,801$ & 0,906 \\
\hline $5.12 \mathrm{~h}$ & 4478,50 & 23641088,45 & $-0,801$ & 0,906 \\
\hline $5.12 \mathrm{i}$ & 4393,29 & 21389413,90 & 0,893 & 0,897 \\
\hline $5.12 \mathrm{j}$ & 4393,29 & 21389413,90 & 0,893 & 0,897 \\
\hline $5.12 \mathrm{k}$ & 4478,50 & 23641088,45 & $-0,801$ & 0,906 \\
\hline 5.121 & 4393,19 & 21390148,00 & 0,893 & 0,897 \\
\hline
\end{tabular}




\begin{tabular}{|c|c|c|c|c|}
\hline $5.12 \mathrm{~m}$ & 4393,19 & 21390148,00 & 0,893 & 0,897 \\
\hline $5.12 n$ & 4478,48 & 23641191,12 & $-0,904$ & 0,906 \\
\hline $5.12 \mathrm{o}$ & 4479,31 & 23638706,69 & $-0,050$ & 0,906 \\
\hline $5.12 p$ & 4325,42 & 21552791,54 & 0,627 & 0,901 \\
\hline $5.13 b$ & 4394,10 & 21387688,87 & 0,893 & 0,897 \\
\hline $5.13 \mathrm{c}$ & 4131,00 & 23229539,88 & 0,054 & 0,912 \\
\hline $5.13 d$ & 4087,04 & 23704459,65 & $-0,061$ & 0,915 \\
\hline $5.13 \mathrm{e}$ & 4394,10 & 21387688,87 & 0,893 & 0,897 \\
\hline $5.13 \mathrm{f}$ & 4138,21 & 23177638,17 & 0,065 & 0,912 \\
\hline $5.14 \mathrm{e}$ & 4479,31 & 23638706,69 & $-0,050$ & 0,906 \\
\hline $5.14 f$ & 4478,83 & 23635873,20 & 0,554 & 0,906 \\
\hline $5.14 \mathrm{~g}$ & 4478,63 & 23640411,18 & $-0,432$ & 0,906 \\
\hline $5.14 \mathrm{~h}$ & 4478,48 & 23641191,12 & $-0,904$ & 0,906 \\
\hline $5.14 \mathrm{i}$ & 4478,50 & 23641088,45 & $-0,801$ & 0,906 \\
\hline (a)3 & 4478,54 & 23637794,88 & 0,220 & 0,906 \\
\hline $7 . b$ & 4478,65 & 23640308,51 & $-0,398$ & 0,906 \\
\hline $9 . b$ & 4478,46 & 23637926,65 & 0,248 & 0,906 \\
\hline 9.c & 4478,40 & 23638472,13 & 0,076 & 0,906 \\
\hline 9.d & 4479,21 & 23636606,92 & 0,530 & 0,906 \\
\hline 9.e & 4478,83 & 23635356,81 & 0,660 & 0,906 \\
\hline $9 . \mathrm{f}$ & 4478,81 & 23635459,49 & 0,642 & 0,906 \\
\hline 10.a & 4478,48 & 23641191,12 & $-0,904$ & 0,906 \\
\hline $10 . b$ & 4478,48 & 23641191,12 & $-0,904$ & 0,906 \\
\hline
\end{tabular}

Alfa de Cronbach 